UNIVERSIDADE DE SÃO PAULO

FACULDADE DE FILOSOFIA, LETRAS E CIÊNCIAS HUMANAS

DEPARTAMENTO DE LETRAS CLÁSSICAS E VERNÁCULAS

PROGRAMA DE PÓS-GRADUAÇÃO EM LITERATURA BRASILEIRA

PEDRO COELHO FRAGELLI

A Paixão segundo Mário de Andrade 


$$
\text { UNIVERSIDADE DE SÃO PAULO }
$$

FACULDADE DE FILOSOFIA, LETRAS E CIẼNCIAS HUMANAS

DEPARTAMENTO DE LETRAS CLÁSSICAS E VERNÁCULAS

PROGRAMA DE PÓS-GRADUAÇÃO EM LITERATURA BRASILEIRA

\title{
A Paixão segundo Mário de Andrade
}

\section{Pedro Coelho Fragelli}

\begin{abstract}
Tese apresentada ao Programa de Pós-Graduação em Literatura Brasileira do Departamento de Letras Clássicas e Vernáculas da Faculdade de Filosofia, Letras e Ciências Humanas da Universidade de São Paulo, para a obtenção do título de Doutor em Letras.
\end{abstract}

Orientador: Prof. Dr. José Antonio Pasta Júnior 


\section{Resumo}

Este trabalho examina a estrutura sacrificial que se encontra no centro da obra de Mário de Andrade. A primeira parte da tese é uma análise do livro de estréia de Mário, Há uma gota de sangue em cada poema, obra que se organiza como um rito sacrificial em que o próprio eu-lírico figura como vítima expiatória. A parte seguinte do trabalho se dedica a estudar a presença decisiva do sacrificio, em seus diversos aspectos, no projeto estético e na obra literária do autor de Macunaima, principalmente na poesia. Por fim, a terceira parte da tese estuda uma das formas sacrificiais por excelência que o sacrifício assume na obra marioandradina - a dança dionisiaca. O trabalho procura enfocar as relações entre a solução sacrificial e o esforço extremo, realizado por Mário, de apreensão da formação histórico-social brasileira. Sacrifício, transe e dança são interpretados como formas paradoxais de representação literária de uma estrutura histórica marcada pelas contradições da modernização conservadora e modelada, em suas origens, pela conjunção de capitalismo e escravidão.

\footnotetext{
Abstract

This work studies the sacrificial structure that lies in the core of Mário de Andrade's work. The first part of the thesis analyses Mário's first book, Há uma gota de sangue em cada poema, work that is organized as a sacrificial rite, in which the lyric subject figures as the scapegoat. The second part investigates the presence of sacrifice, in its various forms, in the aesthetic project and literary works of Macunaima's author, specially in his poetry. Finally, the third part of the work is an interpretation of one of the major forms that sacrifice assumes in Mário's literature - dionysian dance. This work focuses on the relations between sacrificial solution and the extreme effort realizaed by Mário de Andrade to apprehend brazilian's social and historical formation. Sacrifice, trance and dance appear as paradoxical forms that give an image of a historical structure marked by conservative modernization's contradictions and moulded in its origins by the union of capitalism and slavery.
} 
Indice 


\section{$\underline{\text { Indice }}$}

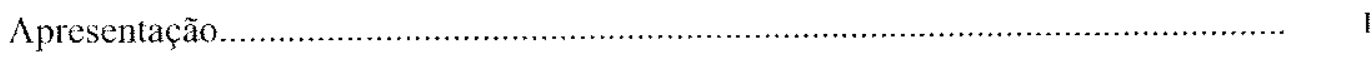

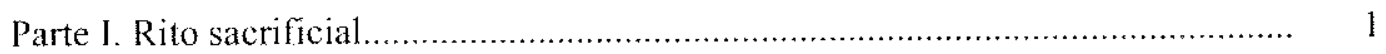

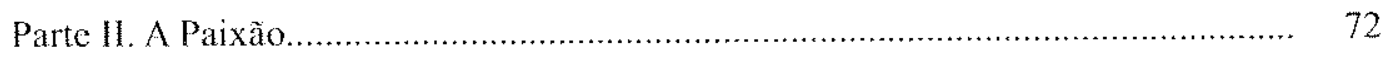

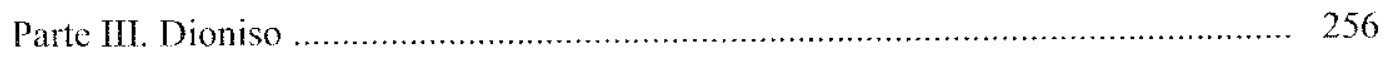

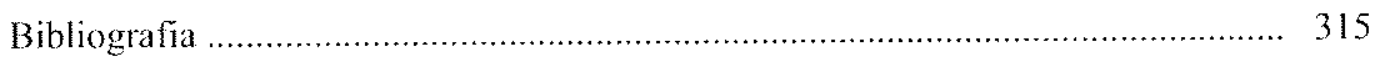




\section{Apresentação}


Uma aura de sacrifício sempre nimbou vida e obra de Mário de Andrade. Um odor de santidade laica sempre emanou de sua entrega à sua obra, operada num grau que ultrapassa as idéias habituais de dedicação e mesmo de missão. O estudo das relações entre literatura e música em Mário de Andrade mostrou-me o quão profundamente a dimensão sacrificial conforma Autor e obra, modelando-as à maneira de uma autêntica Paixão. Quis, então, trazer à luz, tanto quanto possivel, os contornos dessa forma, cujo alcance se revelou tão poderoso.

Assim é que a estrutura sacrificial veio a se tornar o centro deste trabalho. Tratei de verificar amplamente a sua presença e determinar-lhe o sentido, operando nas mediações em que ela se manifesta de modo mais pregnante. Não procurei estudá-la abstratamente, mas vê-la como experiência histórica. Essa passagem sempre tensa entre texto e contexto fica aqui, pelo menos, indicada, ou seja, ancorada em traços gerais, mas decisivos, da formação histórica brasileira.

A exposição vem como segue. A primeira parte do trabalho detém-se na emersão inicial de uma estrutura que se revelará permanente e profunda. A direção da análise concentra-se em Há uma gota de sangue em cada poema, o primeiro livro de Mário de Andrade. Na segunda parte, procuro explicar, na medida em pude fazê-lo, essa estrutura, examinando-a em seus componentes e significados. $O$ foco, então, se reparte, na medida em que opero e ponho em diálogo muitos textos, que vão dos trabalhos de reflexão e das obras literárias de Mário de Andrade à bibliografia especializada. A terceira parte, por fim, ocupa-se daquela que é provavelmente a manifestação artisticamente mais consumada da estrutura sacrificial na poesia de Mário: a dança dionisíaca. Para isso, concentro-me em três poemas nos quais a dança aparece como um princípio de poética, ou seja, "Carnaval Carioca", "O Carto da Miséria" e a série das "Danças".

No capitulo das "fontes e influências", o leitor verá que procurei cobrir, tanto quanto possivel, o campo de estudo em que meu assunto se situa, campo muito amplo, diversificado e de unificação bastante difícil. Nele, apesar da profusão patente e da variedade de elementos de perspectivas diversas, não tenho dúvidas de que o autor central, para mim, foi Marcel Mauss. 
O que me permitiu constelar esse campo, todavia, unificando-o sem rebaixá-lo, e referi-lo à experiência intelectual brasileira, da qual Mário de Andrade é um capitulo decisivo, foi o trabalho que José Antonio Pasta Júnior vem realizando desde a sua tese sobre Raul Pompéia. No curso de minhas leituras de Mário de Andrade, esse trabalho se impôs por si mesmo como uma mediação fundamental, na medida em que sua pertinência se revelou para mim a partir do embate com as dificuldades próprias - e não pequenas - da obra de Mário de Andrade. Assim foi que, a despeito do orientador, e contra as expectativas dele, os seus trabalhos vieram a me fornecer um quadro teórico e uma linguagem, de que me servi conforme quis.

Gostaria de agradecer a todos aqueles que me ajudaram a realizar este trabalho. Agradeço, sobretudo, a José Antonio Pasta Júnior, a quem espero poder sempre retribuir o bem que me fez. Sua orientação teve para mim o sentido de uma formação intelectual, com liberdade. Sou grato, também, à professora Maria Augusta Fonseca e ao professor Walter Garcia, que deram contribuições importantes no exame de qualificação e depois dele, com base em uma leitura generosa e paciente do trabalho. Agradeço, ainda, a meus pais, pelo apoio incondicional de toda sorte, e a minha irmã, que me ajudou em tantas ocasiões. A Michelle, que esteve sempre ao meu lado, devo uma gratidão especial. Sem seu amor diário, acho que não teria tido forças para fazer este trabalho. 
Parte I 


\section{$\underline{\text { Rito sacrificial }}$}

"É um livro muito ruim, mas é a profecia perfeita do que eu teria de ser." Mário de Andrade, sobre Há uma gota de sangue em cada poema.

[Carta a Sousa da Silveira, 26-IV-1935] 
Sabe-se que os ritos mágico-religiosos são precedidos de práticas, também rituais, que preparam o homem para a entrada no domínio do sagrado ${ }^{1}$. Como se o iniciasse em um rito, Há uma gota de sangue em cada poema impõe ao leitor uma série de textos preliminares, que o aprontam para a leitura da obra propriamente dita. Antes de chegar aos poemas do livro, deve o leitor "passar" - trata-se, mesmo, de uma série de passagens - por um título singularmente explicativo, por uma biografia do autor em verso, por uma explicação, em prosa, das razões que levaram o poeta a escrever e a publicar o livro e, finalmente, por um prefácio em forma de soneto. A sucessão de introduções, excessiva mesmo para um livro de estréia, ou para uma "obra imatura", em que se compreende a intenção do autor de apresentar a si e a seu trabalho, exige que o leitor se demore no limiar da obra, como se penetrasse um templo, o que confere um caráter particularmente solene à entrada de Há uma gota de sangue em cada poema. Na medida em que obriga o leitor a realizar uma seqüência de paradas iniciáticas, a deterse em sucessivas estações preparatórias, o conjunto de preâmbulos torna cerimonial a leitura, ao mesmo tempo em que realça a estrutura ritual da composição do livro. Como se verá, Há uma gota de sangue tem, na liturgia católica, especialmente na missa, um de seus modelos compositivos fundamentais.

Trata-se, portanto, de uma obra que dramatiza um rito, assim como a maioria dos poemas capitais de Mário de Andrade. Da imprecação da "Ode ao burguês" ao transe do "Carnaval carioca" e das "Danças", da profecia de "Jorobabel” à encantação do "Acalanto do seringueiro", da iniciação imposta pela "Adivinha" à recitação angustiada da "Meditação sobre o Tietê", da eucaristia sinistra de "Os carnívoros" ao êxtase meditativo da "Louvação da tarde"”, a poesia de Mário de Andrade, em seus

\footnotetext{
${ }^{1}$ Mauss, Marcel. "Esboço de uma teoria geral da magia", in Sociologia e antropologia, São Paulo: Cosac Naify, 2003, pp. 82-87. Caillois, Roger. L’homme et le sacré, Paris: Gallimard, 2006, pp. 50-1.

2 A definição da adivinha como exame preliminar de um rito de iniciação encontra-se em Jolles, André. Formas simples, São Paulo: Cultrix, 1976, pp. 109-127.

3 Em sua interpretação da "Louvação da tarde", Antonio Candido demonstra que o poema de Mário de Andrade entronca-se na tradição da "poesia itinerante", em que se relacionam o sentimento da natureza, a caminhada e a meditação. Com base nesse juízo, mas sem referir-se a misticismo, o crítico ressalta, na meditação realizada pelo eu-lírico, a combinação de reflexão, transcendência e plenitude. Como é sabido, essa combinação é própria da experiência mística. Candido, Antonio. "O poeta itinerante", in $O$ discurso e a cidade, São Paulo/Rio de Janeiro: Duas Cidades/Ouro sobre Azul, 2004, pp. 225-244. Para um comentário sobre as relações entre a meditação e o êxtase, ver Bastide, Roger. Les problèmes de la vie mystique, Paris: PUF, 1996, pp. 33, 57-61.
} 
momentos essenciais, costuma assumir a forma de uma dramatização ritualística. Nos três grandes ciclos da lírica amorosa do autor - "Poemas da negra", "Poemas da amiga" e "Girassol da madrugada" -, a realização do amor é representada como a execução lenta, progressiva e silenciosa de um ato religioso, de um "soleníssimo" rito mortal". Agônico, também, é o ritualismo exercido no "Rito do irmão pequeno", onde a tendência da poesia para a prática ritual encontra sua formulação explícita no título do poema. Finalmente, essa propensão ao rito - que parece ser mesmo uma necessidade, tendo em vista a regularidade com que se verifica nos momentos decisivos da lírica marioandradina - consuma-se no Café, drama em que se precipitam ritos de vegetação, de possessão, de iniciação, de propiciação e de sacrifício, constituindo-se a obra como uma suma da ritualística da poesia do escritor - não por acaso, em Café a poesia de Mário de Andrade toma por fim a forma dramática, própria dos ritos, que tanto a modelou.

A forma da dramatização ritual se verifica, ainda, nas principais obras em prosa de Mário. O jantar intelectual de O banquete, por exemplo, transforma-se aos poucos, segundo a expressão do narrador, "num rito de classe”, em que Janjão, personagem que encarna as contradições do artista dilacerado entre o engajamento e o individualismo, servirá de bode expiatório 5 . "Tempo da camisolinha", um dos contos mais conhecidos do escritor, é sobretudo a narração, por parte do próprio iniciado, de um violento rito de iniciação, que começa com o corte dos cabelos e culmina no sacrifício, quando o narrador entrega seu talismã para melhorar a sorte de um operário ${ }^{6}$. Por fim, para ficar apenas nas obras centrais do escritor, Macunaíma, rapsódia que tem como material, entre outras coisas, um conjunto extenso e variado de mitos amazônicos, cultos africanos e lendas populares, é naturalmente um livro coalhado de ritos mágico-

\footnotetext{
${ }^{4}$ Ao analisar o processo de santificação da vida, Mircea Eliade comenta o fenômeno da transformação da união sexual em rito místico em O sagrado e o profano, São Paulo: Martins Fontes, 2001, pp. 137-141.

${ }^{5}$ Andrade, Mário de. O banquete, São Paulo: Duas cidades, 1989, p. 119.

${ }^{6}$ Idem. "Tempo da camisolinha", in Contos novos, Rio de Janeiro/Belo Horizonte: Villa Rica, 1996, pp. 102-109. Adiante veremos que o movimento de aproximar-se dos pobres, que norteia o nacionalismo e o engajamento de Mário de Andrade, é de natureza sacrificial. Ivone Daré Rabello interpreta o conto "Tempo da camisolinha" em A caminho do encontro: uma leitura de Contos Novos, São Paulo: Ateliê, 1999, pp. 233-241.
} 
religiosos. Entre estes, vale mencionar, pois que se relacionam mais diretamente com os assuntos a serem discutidos neste trabalho, o batismo iniciático de Macunaíma na fonte que o torna branco, a cerimônia de macumba no terreiro de Tia Ciata, em que um dos participantes é possuído por Exu, e a auto-imolação final do herói à beira do Uraricoera. Além disso, o próprio livro, cujo "caráter religioso", segundo Mário de Andrade, "fícou acentuado"7, foi escrito em uma espécie de transe mediúnico, "em pleno estado de possessão", e sua linguagem tende a adquirir virtudes mágicas e encantatórias 9 .

$\mathrm{Na}$ maior parte dos casos mencionados, na poesia como na prosa, o procedimento de dramatização ritual das obras relaciona-se explicitamente a contradições histórico-sociais brasileiras, na maioria das vezes como reação a elas e, mais precisamente, à dificuldade de resolvê-las. Tudo se passa como se o sentimento agudo dessas contradições - talvez nenhum outro autor entre nós as tenha sentido de modo mais intenso e dramático do que Mário de Andrade - levasse o escritor, nos momentos de desespero, nos quais o caráter insolúvel dessas contradições se impunha, a buscar soluções mágicas, míticas, religiosas ou metafísicas em sua obra literária - obra que representa, em seus momentos mais fortes, uma reflexão profunda sobre o Brasil $^{10}$. Conforme espero demonstrar ao longo deste trabalho, a transcendência, na poesia de Mário de Andrade, é inerente ao trato da matéria histórica brasileira; em outras palavras, ela é inseparável do esforço realizado pelo escritor para compreender e dar forma

\footnotetext{
${ }^{7}$ Lopez, Telê Porto Ancona. Macunaíma: a margem e o texto, São Paulo: Hucitec, 1974, pp. 94-95.

${ }^{8}$ A expressão é de Mário de Andrade, em carta a Fernando Sabino. In Andrade, Mário de. Macunaíma, o herói sem nenhum caráter (edição crítica organizada por Telê Porto Ancona Lopez). ALLC XX/Editora da UFRJ, Coleção Archivos, 1996, p. 514. Sobre a relação entre as circunstâncias de criação da rapsódia marioandradina e a estrutura profunda da obra, ver o estudo de José Antonio Pasta Júnior, "Tristes estrelas da Ursa - Macunaíma", in Cadernos Porto \& Virgula, $\mathrm{n}^{\circ}$ 4, Porto Alegre: Secretaria Municipal de Cultura, 1993, pp. 27-32. Sobre o caráter ritualístico das circunstâncias de criação da rapsódia de Mário de Andrade, ver Finazzi-Agrò, Ettore. "As palavras em jogo", in Andrade, Mário de. Macunaíma, op. cit., pp. 306-328.
}

9 Sobre o poder encantatório da linguagem de um dos capítulos mais importantes do livro, ver Fonseca, Maria Augusta. "A carta pras Icamiabas" in Andrade, Mário de. Macunaíma, op cit., pp. 329-345. Sobre o poder mágico da linguagem em Macunaíma, ver Souza, Eneida Maria de. A pedra mágica do discurso, Belo Horizonte: Editora UFMG, 1999.

${ }^{10}$ Inspiro-me, nessa passagem, como em tantas outras, nos trabalhos de José Antonio Pasta Júnior sobre o romance brasileiro, em que o crítico vem demonstrando, nas obras centrais da nossa literatura, em Macunaíma inclusive, a presença recorrente da busca, por parte das personagens, de sínteses mágicas para contradições reais insolúveis, sínteses que se cristalizam, muitas vezes, em objetos mágicos, em fetiches, como a muiraquitã, no livro de Mário de Andrade, ou o emplastro concebido por Brás Cubas. Pasta Júnior, José Antonio. "Prodígios de ambivalência", in Novos Estudos CEBRAP, no 64, São Paulo: novembro de 2002, pp. 61-71. 
artística a uma sociedade marcada pela modernização conservadora - em particular, pela aliança entre a modernização vertiginosa dos anos 1920-30, especialmente em São Paulo, $a$ cidade de Mário de Andrade, e a preservação e o fortalecimento de estruturas socioeconômicas arcaicas ou semi-arcaicas, forjadas no período colonial. O sacrifício, o transe e a magia - assim como a música e a dança, intimamente relacionadas às “soluções rituais" da poesia de Mário de Andrade - resultam da tentativa de assimilar profundamente, na própria estrutura da obra literária, uma formação social caracterizada por dualidades e articulações contraditórias verdadeiramente desconcertantes para o observador que lhe procura compreender o sentido ${ }^{11}$.

Voltando a Há uma gota de sangue em cada poema, sugerimos que, do rito que a obra dramatiza, o título do livro, a "Explicação", a "Biografia" e o "Prefácio" constituem uma fase preliminar de preparação, funcionando como ritos de entrada, ou ritos de limiar $^{12}$. Além da quantidade superior à usual, o próprio teor desses preâmbulos assemelha-se ao das práticas rituais que antecedem as cerimônias mágico-religiosas: neles, o autor sucessivamente faz uma profissão de fé, profere uma encantação mágica propiciatória e transmite ao leitor, como se o iniciasse nos mistérios do livro que está prestes a ler, conhecimentos essenciais sobre a natureza, as origens e as finalidades da obra. A solenidade de que esses textos se revestem - o título, por exemplo, é um verso dodecassílabo e o prefácio, um soneto em decassílabos predominantemente heróicos -, completa a feição litúrgica do pequeno conjunto.

Desde sua abertura, portanto, Há uma gota de sangue em cada poema demanda que o ato de ler se transfigure em participação ritualística. As implicações dessa exigência, como se pode imaginar, não são pequenas. Colhido no processo de absorção ritual imposto pela obra, o leitor é induzido, como qualquer indivíduo que ingressa na

\footnotetext{
11 Ver, por exemplo, o estudo das articulações - e de suas conseqüências políticas, econômicas e sociais entre o desenvolvimento capitalista e a renovação do arcaísmo no Brasil realizado por Florestan Fernandes em A revolução burguesa no Brasil. Ensaio de interpretação sociológica, São Paulo: Globo, 2006.

12 O conceito de "rito de limiar" é apresentado por Arnold van Gennep em seu livro clássico sobre os ritos de passagem. Van Gennep, Arnold. Les rites de passage, especialmente os capítulos I e II. Paris: Picard, 2004, pp. 1-33.
} 
jurisdição do sagrado, a perder suas características específicas ${ }^{13}$ e a dissolver-se na “obscura indivisão do princípio religioso venerado sob o nome de mana"14. A distância entre o leitor e a obra deve converter-se em uma forma ambígua de identificação característica da experiência humana do sagrado -, que estranhamente encerra a alteridade e a identidade ao mesmo tempo ${ }^{15}$. Por sua vez, a reflexão, própria da leitura, transmuda-se na mimese, própria dos ritos. Nestes, como se sabe, o indivíduo deve identificar-se com o que é absolutamente outro, ou seja, com os próprios deuses cujos atos o rito reatualiza - o rito, antes de tudo, é uma imitatio dei ${ }^{16}$. Dessa forma, em $H a ́$ uma gota de sangue em cada poema, o "contrato de leitura" sofre uma alteração que José Antonio Pasta Júnior tem demonstrado ser freqüente na literatura brasileira: "o 'contrato de leitura' - que preserva a distinção das partes em jogo mesmo no mais aceso dos processos identificatórios - duplica-se no caráter fusional do pacto - que por definição supõe um comprometimento dos limites subjetivos"17. No limite, portanto, como uma verdadeira iniciação, o conjunto de prelúdios de Há uma gota de sangue estabelece, como condição de leitura da obra, a própria morte do leitor ${ }^{18}$.

13 Durkheim, Émile. As formas elementares da vida religiosa, São Paulo: Martins Fontes, 2003, pp. 21-24.

14 Adorno, Theodor W.; Horkheimer, Max. Dialética do Esclarecimento, Rio de Janeiro: Jorge Zahar, 1984, p. 28. Hubert e Mauss analisam o conceito de mana em "Esboço de uma teoria geral da magia", in Mauss, Marcel. Sociologia e antropologia, São Paulo: Cosac Naify, 2003, pp. 142-155.

15 Com efeito, de acordo com Rudolf Otto, a experiência do numinoso, ou do sagrado, carateriza-se pela presença de dois sentimentos contraditórios e complementares: o "sentimento do estado de criatura", resultado da consciência da diferença absoluta entre o sujeito e o divino, e o sentimento de comunhão mágica com o numen, objetivo principal da vida religiosa. Nos dois casos, o indivíduo "desaparece". No primeiro, é aniquilado pela superioridade esmagadora do sagrado. No segundo, funde-se ao sagrado. Ver, do Autor, Le sacré, Paris: Payot, 2004, pp. 25-82. Para uma formulação antiga dessa idéia, segundo a qual o divino é simultaneamente semelhante e dessemelhante ao homem, ver, de Agostinho, Confissões, XI, 9, 1. São Paulo: Paulus, 1997, p. 338.

16 Eliade, Mircea. Op. cit., pp. 84-92. Para a caracterização do rito como repetição dos deuses, ver Van der Leeuw, G. La religion dans son essence et ses manifestations. Phénoménologie de la religion, §48, “Comportement et célébration”, Paris: Payot, 1970, pp. 332-335.

17 Pasta Júnior, José Antonio. "O romance do Rosa - temas do Grande Sertão e do Brasil”, in Novos Estudos CEBRAP, nº55, São Paulo: novembro de 1999, p. 62. Ver também, do Autor, Pompéia: a metafisica ruinosa d'O Ateneu, Tese de Doutoramento em Literatura Brasileira apresentada à Faculdade de Filosofia, Letras e Ciências Humanas da USP, São Paulo, 1991, pp. 3-12.

18 Sobre a iniciação, escreveu Eliade: "A passagem do mundo profano para o mundo sagrado implica de uma maneira ou de outra a experiência da Morte”. Eliade, Mircea. Iniciation, rites, sociétés secrètes. Naissances mystiques. Essai sur quelques types de iniciation, Paris: Gallimard, 2008, p. 38. Contudo, enquanto o modelo da iniciação prevê que o iniciado, após sua morte simbólica, renasce como nova pessoa, em Há uma gota de sangue o "segundo nascimento" do leitor não se consuma, encerrando-se a obra com "Os carnívoros", poema em que o leitor é convocado para uma eucaristia às avessas, sinistra e mortal. 
Sendo assim, considerando-se que a seqüência de introduções ao livro tem a função de instruir e de preparar o leitor para a leitura da obra - em outras palavras, tendo em vista que toda iniciação é um processo peculiar de formação -, pode-se afirmar, ainda com base nos estudos de Pasta Júnior sobre o romance brasileiro, que Há uma gota de sangue em cada poema "forma o leitor pela sua supressão"19. Por um lado, em sua quantidade excessiva e em seu teor formativo, o grupo de preâmbulos do livro solicita e constitui, exageradamente inclusive, a instância do leitor. Por outro, contudo, justamente o número excessivo e a feição iniciática desses textos, uma vez que conferem um caráter ritual à entrada da obra, levam a constituição do leitor a dar-se, paradoxalmente, por meio de sua dissolução. Conforme explica Pasta Júnior, a natureza dessa estranha operação, "que ao mesmo tempo supõe o lugar do outro e o anula"20, é contraditória e ruinosa: "num só e mesmo gesto de palavra, a obra produz ou institui seu leitor e, ao mesmo tempo, o suprime ou devora" ${ }^{21}$. Chamado a tomar parte no rito que o livro põe em prática, o leitor de Há uma gota de sangue em cada poema deve, portanto, sujeitar-se a um regime funesto, segundo o qual ele "vem a ser no e pelo movimento mesmo em que deixa de ser"22.

Nos pactos de limiar, aquele que deseja entrar, ou seja, atravessar a porta de entrada de uma casa ou de um templo, deve sacrificar, no limiar dessas edificações, um animal ou um homem aos donos da casa, aos deuses do templo - o sacrifício é o ato por excelência desses ritos de entrada ${ }^{23}$. No "pacto" que Há uma gota de sangue em cada poema impõe logo em sua "porta de entrada", ou seja, em seus preâmbulos, essa lógica de base dos pactos de limiar, como tudo em Mário de Andrade, é levada ao limite de

\footnotetext{
19 Pasta Júnior, José Antonio. Pompéia: a metafísica ruinosa d'O Ateneu, op. cit., p. 3. Sobre o conceito de "formação supressiva", que será examinado detidamente na próxima parte deste trabalho, ver, do Autor, op. cit., pp. 66-80.

20 Pasta Júnior, José Antonio. "O romance do Rosa - temas do Grande Sertão e do Brasil”, in Novos Estudos CEBRAP, nº55, São Paulo: novembro de 1999, p. 64.

21 Pasta Júnior, José Antonio. "Volubilidade e idéia fixa (o outro no romance brasileiro)", in Sinal de menos, $\mathrm{n}^{\circ}$ 4, São Paulo, 2010, p. 25.

${ }^{22}$ José Antonio Pasta Júnior, "O romance de Rosa - temas do Grande Sertão e do Brasil”, in op. cit., p. 64.

23 Trumbull, H. Clay. The threshold covenant or the beginning of religious rites [1906]. Whitefish: Kessinger, 2008.
} 
suas possibilidades de significação. Para penetrar a obra, deve no limiar desta o leitor consentir, religiosamente, em sacrificar-se a si mesmo ${ }^{24}$. Nesse ato extremo, o leitor concelebra o ritual que a própria obra intensamente encena: sem risco de exagero, conforme se verá, pode-se dizer que Há uma gota de sangue em cada poema constituise como um grande rito sacrificial oficiado pelo escritor, em que o eu-lírico se oferece como vítima expiatória.

A imolação do eu-lírico, núcleo da obra, aparece sob a forma de um sinal gráfico, quase um ícone, logo na capa da primeira edição do livro. Com efeito, concebida por Mário de Andrade, a diagramação original de Há uma gota de sangue, que não foi preservada nas edições posteriores do livro, é uma dimensão significativa da obra, onde certas tendências profundas desta última encontram a sua consumação - em especial, como se verá, a propensão de Há uma gota à supressão de mediações que constituem a literatura, como as mediações entre o eu-lírico e a linguagem, entre a linguagem e os objetos que ela representa, entre a obra e o leitor etc. $\mathrm{Na}$ capa, associados à linguagem, os elementos gráficos revelam o sentido íntimo da obra, ou o ato fundador da composição do livro: o sacrifício do eu-lírico. No canto superior direito da página, encontra-se o nome do autor, em verdade um pseudônimo, impresso em negro, como de hábito: MÁRIO SOBRAL. Do sobrenome, escorre uma gota de sangue, em vermelho naturalmente:

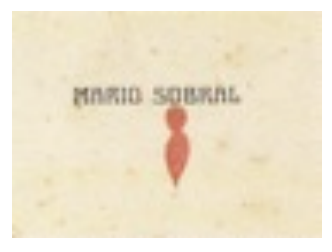

Além de corresponder à timidez do escritor, confessada no poema que abre o livro, e a uma prática comum dos poetas de todos os tempos, a utilização do pseudônimo em Há uma gota de sangue participa, por si mesma, da estrutura sacrificial

\footnotetext{
${ }^{24}$ Em última análise, o ingresso do indivíduo no domínio do sagrado implica sempre, de um modo ou de outro, seu sacrifício. Hubert, Henri; Mauss, Marcel. "Ensaio sobre a natureza e a função do sacrifício", in Mauss, Marcel. Ensaios de sociologia, São Paulo: Perspectiva, 2005, pp. 156-158.
} 
que organiza a obra. Segundo a lógica do sacrifício, a vítima substitui o sacrificante, ou seja, a comunidade ou o indivíduo que esperam ser resgatados por meio da imolação. Ora, o eu-lírico de Há uma gota, que se oferece em sacrifício para salvar a humanidade, substituindo-a na expiação da violência praticada na guerra mundial, é também um substituto do próprio escritor, o que se evidencia quando este se apresenta sob a forma do pseudônimo. No sacrifício, a substituição somente acontece quando a vítima é ao mesmo tempo idêntica ao sacrificante $e$ distinta dele: "Para que a vítima possa polarizar e purgar as paixões, é necessário que seja semelhante a todos os da comunidade e ao mesmo tempo dessemelhante, simultaneamente próxima e longínqüa, a mesma e a outra, o duplo e a Diferença" ${ }^{25}$. A vítima pertence, portanto, ao interior e ao exterior da sociedade, ela está dentro e fora desta; está, em suma, na margem. Como se verá, essa é a condição do eu-lírico de Há uma gota em relação aos homens que ele pretende redimir, isto é, à civilização ocidental devastada pela Primeira Guerra: ele pertence e não pertence ao Ocidente, participa e não participa dos combates - ele se encontra, em síntese, na periferia do sistema capitalista. Note-se, entretanto, por ora, que o eu-lírico, em seu nome, Mário Sobral, encontra-se em situação parecida em relação ao autor do livro: ele é o mesmo - Mário - e o outro do escritor; ele é e não é Mário de Andrade, constituindo-se, assim, como uma espécie de mediação ambígua ou precária - ou melhor, constituindo-se e não se constituindo como instância mediadora. Noutro termos, se por um lado o pseudônimo representa uma mediação a mais entre o autor e o eulírico, por outro ele sugere, em Há uma gota de sangue, a supressão da mediação que o eu-lírico costuma ser em poesia. Não raro, a lírica de Mário procura instaurar uma passagem contínua - isto é, não mediada - do escritor para o eu-lírico, deste para o poema e do poema para o leitor.

Segundo a boa teoria, contigüidades dessa ordem são características do esquema sacrificial, em que uma série de identificações sucessivas se estabelece entre o sacrificante, o sacrificador (o oficiante), a vítima e a divindade ${ }^{26}$; ao mesmo tempo,

\footnotetext{
${ }^{25}$ Girard, Réné. A violência e o sagrado, São Paulo: Paz e Terra, 1998, p. 365.

${ }^{26}$ Lévi-Strauss, Claude. O pensamento selvagem, Campinas: Papirus, 2007, pp. 248-254.
} 
contudo, o sacríficio confirma a diferença existente entre os atores que o encenam caso contrário, o sacerdote e o sacrificante pereceriam com a vítima. Todo sacrifício, portanto, ratifica a diferença entre o sagrado e o profano; não obstante, todo sacrifício suprime a diferença entre o sagrado e o profano. Em outras palavras, o sacrifício diferencia e identifica, ele institui, simultaneamente, a diferença e a identidade entre o mesmo e o outro ${ }^{27}$ : “o sacrifício é o operador da diferenciação universal, ao mesmo tempo em que, no mesmo movimento, ele suprime toda diferenciação"28. No rito que se dramatiza em Há uma gota de sangue, vimos, o oficiante e a vítima, isto é, o escritor e o eu-lírico, são justamente idênticos $e$ distintos, duplicidade que se manifesta no pseudônimo escolhido pelo autor.

Não por acaso, a gota de sangue ilustrada na capa do livro escorre do sobrenome SOBRAL, ou seja, do nome que diferencia o eu-lírico do escritor. O eu-lírico é a vítima sacrificial em Há uma gota de sangue em cada poema; autor e leitor, como se verá, compartilham seu destino funesto, mas em função dos desdobramentos e das contaminações simbólicas do sistema do sacrifício - a vítima expiatória, a rigor, é apenas o eu-lírico. Sua imolação é realizada no limiar da obra - na capa do livro -, como de regra nos rituais mágico-religiosos primitivos. Uma vez que o sacrifício é a operação suprema que permite realizar a passagem do profano no sagrado e vice-versa, pode-se afirmar que o limiar e o sacrifício têm, por assim dizer, afinidades profundas: o limiar é o lugar privilegiado da execução sacrificial; esta, por sua vez, consiste no ato principal dos ritos de $\operatorname{limiar}^{29}$. Não é à toa que o Cristo, a vítima expiatória por

\footnotetext{
${ }^{27}$ Por isso, como se verá no capítulo seguinte deste trabalho, há uma homologia estrutural entre a relações sacrificiais e as relações sociais no Brasil, uma vez que entre nós, conforme demonstra José Antonio Pasta Jr. em seus trabalhos sobre a literatura brasileira, a conjunção de capitalismo e escravidão instaurou a vigência simultânea de dois regimes opostos de relação interpessoal: um regime que corresponde às relações capitalistas de produção, e que prescreve a diferença entre o mesmo e o outro; e outro, que corresponde aos laços do patriarcalismo escravista, em que essa diferença é inconcebível. Dessa forma, nas relações sociais brasileiras, a alteridade é afirmada e negada ao mesmo tempo, como no interior do rito sacrificial. Não por acaso, conforme se verá, a "solução" para essa contradição de base das relações intersubjetivas no Brasil é sobretudo, afirma Pasta, uma solução sacrificial. Pasta Júnior, José Antonio. "Volubilidade e idéia fixa (o outro no romance brasileiro)", in Sinal de menos, nº4, São Paulo: 2010, pp. 13-25.

28 Herrenschmidt, Olivier. "Sacrifice symbolique ou sacrifice efficace", in Izard, Michel; Smith, Pierre (orgs.). La fonction symbolique: essais d'anthropologie, Paris: Gallimard, 1979, p. 174.
} 
excelência, teria afirmado, segundo João, "Eu sou a porta"30 . O limiar, noutros termos, é o mais antigo altar; nele, o eu-lírico de Há uma gota de sangue é sacrificado em nome da humanidade, convulsionada pela Primeira Grande Guerra.

A imolação, contudo, não costuma bastar nos rituais de entrada no espaço sagrado. Para completar o rito, deve-se verter o sangue da vítima sobre o limiar ou mesmo marcar o limiar com o sangue da vítima. A marca de sangue é o signo da união, consumada no sacrifício, entre o profano e o sagrado, entre quem entra e quem reside no interior. Atravessar o limiar marcado com sangue significa ratificar um pacto com o divino: ao virar a página de capa de Há uma gota, na qual se encontra impressa a marca do sangue do eu-lírico imolado, o leitor confirma um pacto mortal com a obra que ele "adentra". Vimos com José Antonio Pasta Jr. que a figura do pacto distingue-se do modelo do contrato, uma vez que, por definição, ela compromete a distância entre as partes que o celebram, ou seja, uma vez que ela tem um caráter fusional. Nessa linha, o pacto que Há uma gota de sangue estende ao leitor é aquele em que a comunhão dos pactários é absoluta, o pacto de sangue. Este, escreve Trumbull, autor de um longo estudo sobre o assunto, “forma a mais íntima, sagrada e indissolúvel aliança que se pode conceber. O pacto de sangue envolve a entrega absoluta do ser separado e uma fusão irrevogável da natureza individual com o outro incluído no pacto"31. "O sangue é um extrato muito especial", diz Mefistófeles, ao comunicar a Fausto que ao sábio basta assinar o contrato entre ambos com uma gota de sangue, para que o acordo seja firmado ${ }^{32}$. Nesse contexto, o sangue não é reconhecido apenas como uma substância essencial à vida ou que representa a vida, mas como a vida mesma; o sangue carrega a vida, de modo que sua efusão em um pacto significa a entrega da própria vida ao outro. Com efeito, o pacto de sangue, em sua forma extrema, "não pode consumar-se sem a morte de quem pactua" ${ }^{33}$. Vida em troca de vida, eis a divisa do pacto de sangue, na qual

\footnotetext{
30 João: 10:9, in Bíblia Sagrada - "Novo Testamento", São Paulo: Sociedade Bíblica do Brasil, 1969, p. 135.

31 Trumbull, H. Clay. Blood covenant, Whitefish: Kessinger, 2009, p. 204.

32 Goethe, Johann Wolfgang von. Fausto, Belo Horizonte: Villa Rica, 1992, p. 84.

${ }^{33}$ Idem. Ibidem, p. 284.
} 
o leitor terá reconhecido o princípio do sacrifício, sacrifício que é, entre outras coisas, a forma mais complexa do pacto de sangue.

Uma vez que a supressão dos limites que separam o mesmo do outro, supressão também operada no pacto de sangue, é a própria forma por que se constitui o eu-lírico em Há uma gota, a obra tende a suprimir mediações em outros níveis importantes da composição, como na linguagem. Olhando bem, a gota de sangue marcada sob o pseudônimo do autor tem a forma da pena de metal das canetas antigas. O sangue do eulírico - que é também o sangue do escritor, na medida em que as duas instâncias se identificam na obra - é a tinta mesma com que Mário se concebe escrevendo. Não por acaso, ainda na capa do livro, no centro da página, o título da obra é impresso em vermelho, isto é, na mesma cor da gota de sangue marcada sob o pseudônimo do autor:

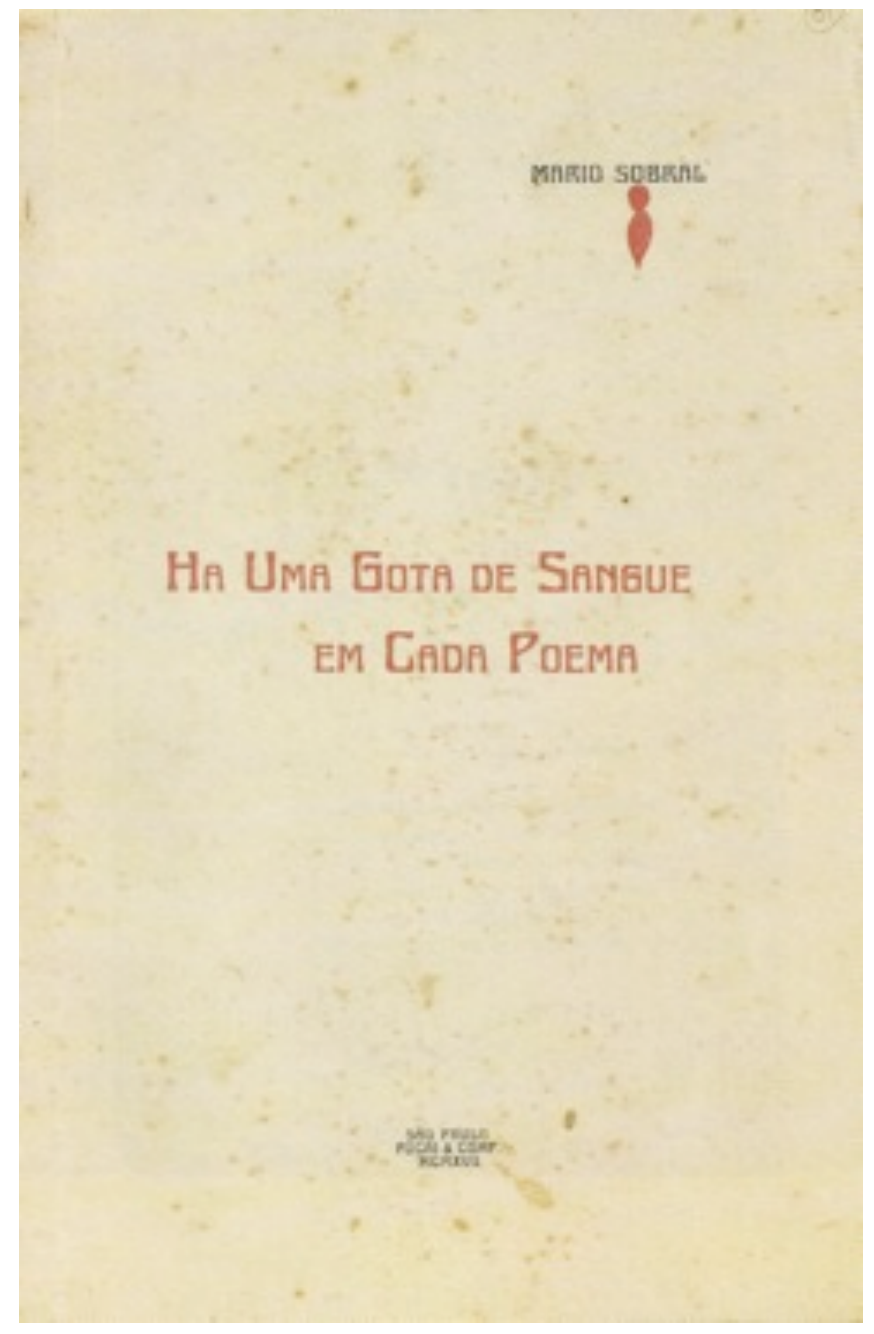


O sangue se faz palavra em Há uma gota; com ele a própria escrita é traçada. $\mathrm{O}$ vermelho em que se imprime o título da obra assinala o desígnio de suprimir não apenas a distâncias entre o sangue da vítima e a linguagem, mas também a distância entre a linguagem e a sua impressão no papel. Noutros termos, a linguagem não representa, apenas, o sangue que emana do martírio do eu-lírico, mas quer ser esse sangue, o qual, por sua vez, é a própria tinta com que o autor quer imprimir cada exemplar de seu livro. Desse modo, mediações que são próprias da linguagem literária - mesmo em poesia, onde elas podem atenuar-se ${ }^{34}$, , ou seja, mediações entre o escritor e a palavra ${ }^{35}$, entre a palavra e o sentido e entre a linguagem e sua reprodução gráfica, em suma, mediações entre as esferas da representação e da realidade, tendem a ser abolidas em Há uma gota de sangue. No horizonte da obra, a escrita realiza o martírio, de modo que o sangue esteja presente, fisicamente, nas páginas do livro ${ }^{36}$.

O conteúdo inusitado do título reforça esse impulso para a supressão das distâncias. O leitor terá notado que o título do livro é bastante original, esquisito mesmo, uma vez que foge do modelo habitual dos títulos, o do substantivo combinado ou não com adjetivo, e assume a forma de uma oração completa: Há uma gota de sangue em cada poema. Em seu caráter por assim dizer prosaico, o título parece dizer ao leitor: "não se trata, aqui, de metáfora; há (realmente) uma gota de sangue em cada poema". O título da obra contém, portanto, uma recusa do sentido figurado da linguagem; ele afirma o significado literal das palavras, alertando ao leitor que não subestime o sacrifício praticado na composição do livro, sugerindo que esse sacrifício

\footnotetext{
${ }^{34}$ Hegel, G. W. F. Curso de Estética: o Sistema das Artes, São Paulo: Martins Fontes, 1997, pp. 359-433.

${ }^{35}$ A escrita com sangue estabelece um vínculo íntimo entre a palavra e o escritor: "como parte mesma da pessoa, a escrita se torna fisicamente ligada a quem escreve". Albert, Jean-Pierre. Le sang et le Ciel: les saintes mystiques dans le monde chrétien, Mayenne: Aubier, 1997, p. 388.

${ }^{36}$ No livro seguinte de Mário, Paulicéia desvairada, as vanguardas e a psicanálise fornecerão ao escritor a base para uma formulação teórica da exigência de uma imediatidade semelhante, ou seja, da demanda de que a "natureza profunda" do poeta fique retida, como que de forma física, no poema. O sangue será, então, substituído pelo inconsciente, como repositório do "ser" do eu-lírico. A transfusão do interior do eu-lírico para a linguagem, que em Há uma gota é a transfusão sangüínea, isto é de uma substância, tornase em Paulicéia uma "transferência energética", nos termos de Roberto Schwarz. Por fim, note-se que essa cristalização do inconsciente na linguagem é apresentada em Paulicéia como o núcleo do lirismo, uma concepção que Mário nunca abandonaria. Andrade, Mário de. Paulicéia desvairada, in Poesias completas (ed. crítica de Diléa Zanotto Manfio), Belo Horizonte/Rio de Janeiro: Villa Rica, 1993, pp. 59-77. Ver Schwarz, Roberto. "O psicologismo na poética de Mário de Andrade", in A sereia e o desconfiado, São Paulo: Paz e Terra, 1981, pp. 13-23.
} 
deve ser tomado ao pé da letra. Com efeito, sobre cada poema do livro, o leitor encontrará, na primeira edição da obra, a marca de uma gota rubra, ora junto ao título do poema, ora entre os próprios versos.

O título do livro refere-se também, portanto, a uma espécie de sacrifício metodizado - ou seja, a um rito: há uma gota de sangue em cada poema. Em outras palavras, a escrita não se realiza como um derramamento incontido do sangue do eulírico, mas sob a forma de uma aspersão mínima e rigorosamente controlada do fluido vermelho. A dosagem da efusão de sangue da vítima, com efeito, integra uma das funções básicas dos ritos, sacrificiais ou não: regular a relação entre o profano e o sagrado com o objetivo de garantir que o contato entre essas suas instâncias não seja mortífero para a primeira, tendo em vista que o sagrado é uma energia ambígua e perigosa, que pode aniquilar o indivíduo se não for ministrada com precaução extrema. Ora, o sangue da vítima sacrificial é o próprio sagrado; como ele, o sangue expiatório é ao mesmo tempo fonte da vida e produto da morte - ele suja e limpa, torna impuro e purifica, leva os homens ao furor e os apazigua ${ }^{37}$. Em síntese, o sangue é uma espécie de pharmakós, isto é, uma substância que funciona como remédio, se aplicada em doses baixas, mas como veneno, caso seja utilizada em grande quantidade. O termo grego, vale notar, refere-se justamente à vítima sacrificial antiga, escolhida entre os indivíduos "marginais" (criminosos, deficientes etc.), e que concentrava todos os males que afligiam a cidade; a vítima é portanto imunda e maléfica, mas em sua imundície e em seu malefício ela é impoluta e benéfica, uma vez que, ao assumir em si mesma os males de que sofre o grupo social, ela purifica a sociedade que a sacrifica - a vítima expiatória é o pharmakós por excelência.: “As vítimas têm sempre algo de medicinal. [...] Todos os perseguidores atribuem a suas vítimas uma nocividade suscetível de se converter em positividade e vice-versa"38; "A vítima representa tanto a morte como a vida, a doença como a saúde" 39 . O sacrifício, por sua vez, consiste nesses casos, antes de tudo, em uma violência controlada que põe fỉm, por meio da catarse coletiva, à violência generalizada,

\footnotetext{
${ }^{37}$ Girard, Réné. A violência e o sagrado, op. cit., p. 52.

${ }^{38}$ Idem. Le bouc émissaire, Paris: Grasset \& Fasquelle, 2006, p. 74.

${ }^{39}$ Hubert, Henri; Mauss, Marcel. "Ensaio sobre a natureza e a função do sacrifício”, in op. cit., p. 196.
} 
à guerra de todos contra todos que devasta a totalidade da sociedade ${ }^{40}$. Com efeito, por meio da auto-imolação, o eu-lírico de Há uma gota pretende encerrar a Primeira Guerra Mundial; trata-se de estancar o derramamento de sangue por meio da aspersão regulada do sangue expiatório.

Ao assumir, como mediação suprema da obra, uma panacéia ambivalente, $H a ́$ uma gota se insere em uma "tradição" das nossas letras. Conforme observou José Antonio Pasta Jr., muitas das obras capitais da literatura brasileira configuram, cada uma a seu modo, com distância ou não, uma espécie de remédio universal, de caráter mágico, capaz de "resolver" contradições insolúveis, de curar todos os males, mas às custas da morte, ou melhor, trazendo a morte ${ }^{41}$. Revelando a existência, na prosa do Brasil, de uma galeria de "panacéias nacionais", que incluem o emplastro concebido por Brás Cubas e a muiraquitã de Macunaíma, o crítico nota que esses pharmakoi, uma vez que operam a passagem da morte na vida e da vida na morte, portanto do mesmo no outro e do outro no mesmo, reproduzem, na esfera literária, o núcleo mesmo da estrutura histórico-social brasileira, isto é, o regime dúplice e profundamente contraditório da modernização conservadora ${ }^{42}$.

De fato, se é possível expressar-se assim brevemente, a modernização conservadora consiste sobretudo em uma incorporação restrita e torcida, controlada pelos donos do poder, da modernidade, de modo que esta funcione às avessas, isto é, como reposição do arcaísmo. Durante a República Velha, a adoção, pelas elites, de algumas formas modernizantes em sentido arcaico aprofundou o arcaísmo nas relações de produção e nas estrutura econômica, assim como na prática política ${ }^{43}$. O ano em que Há uma gota de sangue foi escrito, 1917, é também o ano da grande greve que parou o Estado de São Paulo, por meio da qual os operários exigiam direitos mínimos que garantissem sua sobrevivência - como a possibilidade de faltar por doença, mesmo que

\footnotetext{
${ }^{40}$ Girard, Réné. A violência e o sagrado, op. cit..

${ }^{41}$ Pasta Júnior, José Antonio. "Prodígios de ambivalência", in Novos Estudos CEBRAP, nº 64, São Paulo: novembro de 2002, pp. 68-71.

${ }^{42}$ Idem. Ibidem.

43 Para um panorama desse processo, ver Carone, Edgard. A República Velha (instituições e classes sociais), São Paulo: Difusão Européia do Livro, 1970.
} 
sofrendo desconto $(!)^{44}$-, o que dá a medida do grau de exploração do trabalho nas indústrias paulistas à época, em muitos aspectos semelhante à exploração da mão-deobra nos tempos da escravidão. Desse modo, as relações de produção nas fábricas assumiam formas pré-burguesas em toda linha: “em uma das maiores indústrias de tecidos de São Paulo, a de Jaffet, em 1917 ainda paga seus operários com vales, que devem ser trocados em armazéns de seus parentes"45. Como se sabe, a greve não venceu, ao contrário: é a partir da greve de 1917 que as classes dirigentes iniciarão a repressão sistemática do movimento operário brasileiro, bloqueando a formação da luta de classes própria da modernidade burguesa ${ }^{46}$.

Retomaremos posteriormente, de modo mais aprofundado, o estudo da modernização conservadora. Nesta altura, basta notar que esse estranho ritmo histórico possui em seu núcleo uma estrutura parecida com a da utilização do phamakós, isto é, o emprego regulado do mesmo para evitar o mesmo, ou seja, de forma que ele se torne o outro. Nesse sentido, no campo da literatura brasileira, ao figurarem o pharmakós, as obras apreendem, embora essa relação não seja evidente, a dinâmica profunda da formação histórica nacional - o que significa, por si só, uma verdadeira conquista, dada natureza hipercontraditória desse movimento histórico ${ }^{47}$. O valor crítico dessa mimese, contudo, depende em grande parte de que ela inclua o elemento da distância; noutros termos, ao incorporar o pharmakós sem esse elemento, a obra de arte reproduz a matéria que ela configura e que a domina. Esse é o caso de Há uma gota de sangue, assim como de outras obras de Mário de Andrade. Com efeito, muitos poemas de Mário, conforme se verá ao longo deste trabalho, confiam no pharmakós, em particular no sacrifício, como meio de resolução de contradições histórico-sociais que aparecem como

\footnotetext{
${ }^{44}$ Idem. Ibidem, p. 230.

${ }^{45}$ Idem. Ibidem, p. 192.

${ }^{46}$ Beiguelman, Paula. A formação do povo no complexo cafeeiro: aspectos políticos, São Paulo: Pioneira, 1978.

47 Especialistas demostram, por exemplo, como a assimilação arcaica do moderno na economia da República Velha produziu contradições econômicas propriamente irresolúveis. Furtado, Celso. Formação econômica do Brasil, São Paulo: Companhia Editora Nacional, 2003, pp. 177-194. Oliveira, Francisco de. "A emergência do modo de produção de mercadorias: uma interpretação teórica da economia da República Velha no Brasil", in Fausto, Boris (org.). História geral da civilização brasileira, tomo III: o Brasil Republicano, $1^{\circ}$ volume, Rio de Janeiro: Bertrand Brasil, 1997, pp. 393-414.
} 
insolúveis; todavia, a assunção do sacrifício como mediação suprema da composição poética costuma ser deceptiva e terminal nesses textos, nos quais ela resulta em morte e destruição.

O sacrifício, na poesia de Mário, é portanto um ato trágico, pois o autor não adere - como adere, por exemplo, a música modernista de Stravinski, segundo Adorno ao ponto de vista da coletividade que sacrifica o indivíduo ${ }^{48}$. Ao contrário, Há uma gota de sangue se estrutura a partir de o que José Antonio Pasta Júnior chamou de "ponto de vista da morte", entendido o ponto de vista não simplesmente como o foco narrativo, mas como o modo de apreensão da matéria histórica por parte da obra literária, isto é, como o “"ponto epistemológico" por excelência" das obras; assim, nas obras organizadas a partir do ponto de vista da morte, esse ponto epistemológico é o próprio instante mortal, ou seja: nelas, a matéria é apreendida in articulo mortis ${ }^{49}$. No caso de Há uma gota de sangue, o instante mortal assume a forma do sacrifício. O ponto de vista é o da vítima expiatória e se forma no instante da imolação. Nesse sentido, as implicações destrutivas da operação sacrificial são incorporadas pelas obras em toda linha, acabando por prevalecer; as contradições intrínsecas ao sacrifício, em vez de suprimidas ou encobertas, são levadas aos seus limites, em que se aniquilam o indivíduo e a sociedade, numa espécie de vertigem. Desse modo, embora não supere, no sentido dialético da palavra, a matéria histórica que apreende, ou seja, o movimento da modernização conservadora, embora portanto reponha a dinâmica e a estrutura desse movimento contraditório, a obra de Mário o esgota, de forma que ele evidencia a sua natureza ruinosa. Mesmo em Há uma gota, obra marcada pela formação católica do escritor, o sacrifício não resgata a humanidade; ao contrário, condena-a a uma maldição - o horror do canibalismo - e, no limite, à própria extinção: como se verá, no último poema do livro, o eu-lírico convoca os leitores, como mencionado acima, a uma eucaristia às avessas, isto é, a comungar o pão feito do trigo que cresce nas terras

\footnotetext{
${ }^{48}$ Adorno, Theodor W. Philosophie de la nouvelle musique, Paris: Gallimard, 2000, pp. 147-171.

49 Pasta Júnior, José Antonio. "Le point de vue de la mort (une structure récurrente de la culture brésilienne", in Voies du paysage, Cahiers du CREPAL, n 14 (dir. Jacqueline Penjon), Paris: Presses Sorbonne Nouvelle, 2007,
} 
regadas com o sangue tóxico, imundo de crimes, dos soldados mortos em combate. Apesar do significado ambivalente que o sangue tem na obra, como fonte de vida e de morte, triunfa afinal o sangue-veneno, mortífero.

Não obstante o caráter negativo do último poema, Há uma gota de sangue estrutura-se como um ritual que tem em seu centro o princípio do sacrifício renovador. Virada a página de capa, ou melhor, atravessado o limiar do obra, no qual é firmado o pacto de sangue com o eu-lírico, o leitor depara outra "estação preliminar" aos poemas do livro: uma breve "biografia" em versos do escritor, que funciona como uma espécie de "apresentação das qualidades da vítima expiatória", comum nos ritos sacrificiais. Com efeito, segundo Hubert e Mauss, uma das práticas habituais com que se iniciam esses rituais é a "exposição e descrição" da vítima aos deuses e aos que fazem parte do rito $^{50}$. Não por acaso, em Há uma gota, a "Biografia", como o título da obra, também foi impressa em vermelho; Mário Sobral (ou de Andrade) narra sua vida com seu próprio sangue ${ }^{51}$ :

“São Paulo o viu primeiro.

Foi em 93.

Nasceu, acompanhado daquela

estragosa sensibilidade que

deprime os seres e prejudica

as existências, medroso e humilde.

E, para a publicação destes

poemas, sentiu-se mais medroso e mais humilde, que ao nascer.

Abril de 917"

\footnotetext{
${ }^{50}$ Hubert, Henri; Mauss, Marcel. "Ensaio sobre a natureza e a função do sacrifício”, in op. cit., p. 171.

${ }^{51}$ Não foi possível reproduzir, como fiz com a capa, a página da primeira edição que contém "Biografia".
} 
Como terá notado o leitor, o poema repõe a ambigüidade, instaurada pelo pseudônimo, que marca e apaga os limites entre o autor e o eu-lírico em Há uma gota de sangue. Os versos aludem, claro, a Mário de Andrade, nascido em São Paulo, no ano de 1893, sugerindo-se desse modo a identidade entre quem fala no poema e sobre quem o poema fala. Não obstante, o poema não nomeia o escritor, dando margem a alguma incerteza - o texto pode referir-se a um outro, que não se confunde com o autor da obra. Além disso, o poema é composto em terceira pessoa, como se fossem distintos o sujeito do discurso e aquele a quem o texto se refere. Sendo assim, a relação entre essas duas instâncias é de identidade e de alteridade ao mesmo tempo, de modo que o escritor e o eu-lírico as ocupam de maneira simultânea e alternada. $\mathrm{O}$ escritor $e ́$ o eu-lírico $e$ o escritor não é o eu-lírico; o escritor fala do eu-lírico $e$ o eu-lírico fala do escritor. Em suma, ambos são duplos um do outro.

O poema tem certo tom bíblico, e lembra em alguma medida, na linguagem como no conteúdo, os textos dos evangelistas. "São Paulo o viu primeiro" informa ao leitor a cidade em que nasceu o poeta do livro; entretanto, o verso não menciona “cidade” nem "poeta". "São Paulo", portanto, parece indicar também o próprio santo católico, que presencia, no poema, o nascimento de alguém cujo nome não é dito, o que confere certa aura de mistério a essa pessoa. O verso seguinte, "Foi em 93", diz o ano em que Mário nasceu, mas também de forma especial: a estrutura sintática com sujeito oculto envolve o acontecimento com uma atmosfera misteriosa, e a notação da data, sem indicação do milênio e do século, remete a tempos remotos. Juntos, os dois versos sugerem a ocorrência de um nascimento especialíssimo, uma vez que tudo - o local, a pessoa, o fato e a data - permanece em parte oculto. A linguagem, ao mesmo tempo em que solene, realiza-se em estilo humilde, num despojamento que antecipa a poesia modernista, mas que também tem muito da simplicidade do cristianismo antigo aspirando a algo como "a perfeição simples e ao mesmo tempo grandiosa", que para Mário de Andrade exprimia a essência do catolicismo ${ }^{52}$.

52 Andrade, Mário de. "Crítica do gregoriano”, in Música, doce música, Belo Horizonte: Itatiaia, 2006, p. 27. 
A combinação do elevado e do humilde que marca o discurso do poema concentra-se na aparição do verbo nascer, no terceiro verso. Por um lado, por ter sido retardada, preparada, essa aparição é grandiosa: "Nasceu", anuncia o poema solenemente; por outro lado, o anúncio resume-se ao verbo nu, sem aparato, o que lhe dá um caráter simples, simplicidade representada por uma vírgula, que isola o verbo: "Nasceu,". Os adjuntos adverbiais, "medroso e humilde”, reforçam a idéia do simples, associando-a à imagem cristã da alma sensível, que se encontra, por sua vez, na longa oração interposta entre o verbo e os adjuntos: "acompanhado daquela/ estragosa sensibilidade que/ deprime os seres e prejudica/ as existências". Embora seja extensa, o que lhe confere certa feição grandiloqüente, a oração é direta, tem um caráter prosaico, o qual é transferido para a composição poética na medida em que a frase se divide em quatro versos curtos. Desse modo, preserva-se a conjunção dos estilos elevado e humilde, própria do poema como um todo.

O verso seguinte, que abre um novo período, inicia-se com a conjunção aditiva "e". Trata-se de uma construção muito comum nos textos bíblicos, sendo predominante nos quatro evangelhos - nos livros de Marcos e Lucas, por exemplo, a maior parte dos versículos começa dessa forma. No poema de Mário, a conjunção "e" estabelece uma ligação entre o período anterior, que trata do estado de espírito do poeta ao nascer, e o período que ela inicia, que trata do estado de espírito do poeta ao publicar seu livro. O estado é o mesmo, dizem os versos, porém é mais intenso no momento da publicação do que no momento do nascimento - nesse sentido, ele é o mesmo, mas também é outro: "E, para a publicação destes/ poemas, sentiu-se mais medroso e mais humilde, que ao nascer". Desse modo, forma-se no poema um paralelismo entre nascer e publicar, compondo-se um quadro em que publicar corresponde a nascer e nascer, a publicar. Mais precisamente, a publicação aparece como um segundo nascimento, mais dramático do que o primeiro - o grande número de enjambements no poema reproduz, no plano formal, a idéia da ligação entre o passado e o presente, entre o anterior e o posterior.

À vista disso, e considerando-se que o livro é a estréia poética de autor, por meio da qual este passa a fazer parte da "sociedade dos escritores", pode-se dizer que a 
publicação de Há uma gota tem, aqui, o sentido de uma iniciação, que o poeta enfrenta, não por acaso, "medroso e humilde". Com efeito, o movimento, que o poema realiza, de regressão ao tempo da origem, ao primeiro nascimento, e de passagem pelo segundo nascimento encontra-se em geral no centro dos rituais iniciáticos, em especial nos ritos de puberdade. Estes, como toda iniciação, têm natureza sacrificial, uma vez que consistem em um processo de formação em que o sujeito se forma por meio de sua supressão, isto é, segundo o regime, mencionado anteriormente, que José Antonio Pasta Júnior definiu como o da formação supressiva - afinal, o sacrifício é sobretudo uma operação pela qual um objeto se torna sagrado, vem a ser, por meio de sua destruição ${ }^{53}$. Não é à toa que as iniciações de puberdade, nas religiões primitivas, costumam incluir a mutilação dos iniciados, que em seguida são banhados em seu próprio sangue, como o poema de que estamos fazendo a análise, impresso em tinta rubra ${ }^{54}$.

Cortados e ungidos com sangue, os noviços iniciam-se nos mistérios do sangue, isto é, passam a conhecer a relação obscura, pois que supõe a morte, entre o sangue e a fertilidade, entre o sangue e a renovação da vida - a iniciação, como se sabe, termina com o renascimento do iniciado depois de sua morte simbólica ${ }^{55}$. Ora, a idéia do sangue fértil está no núcleo mesmo de Há uma gota, e encontra-se intimamente associada ao princípio de poética do livro, ou seja, o sacrifício: somente no sacrifício o sangue derramado deixa de ser impuro, deixa de tudo conspurcar com as cores da violência e da morte, e adquire a virtude fecundante de dar a vida, de purificar o que está imundo e de fazer reviver o que está morto. Não por acaso, "Biografia" vem datada de "Abril”, o primeiro mês da primavera e da germinação na Europa, onde o eu-lírico se situa em toda a obra, e o mês da Páscoa, da celebração da ressurreição de Cristo. A forte presença do modelo da Páscoa no livro será estudada adiante. Por ora, lembre-se apenas que algumas tradições da Páscoa associam-na ao advento da primavera; certos símbolos

\footnotetext{
53 Hubert, Henri; Mauss, Marcel. "Ensaio sobre a natureza e a função do sacrifício", in op. cit., p. 149. Herrenschmidt, Olivier. "A qui profite le crime? Cherchez le sacrifiant", in L'homme. Revue française d'anthropologie, XVIII (1-2), Paris: EHESS, jan/jun 1978, pp. 7-18.

54 Sobre as iniciações de puberdade, ver Eliade, Mircea. Iniciation, rites, sociétés secrètes. Naissances mystiques, op. cit., pp. 23-96.

${ }^{55}$ Idem. Ibidem, pp. 72-73.
} 
pascais que representam a fertilidade teriam sua origem nas festividades pagãs da primavera e o próprio esquema do sacrifício e da ressurreição de Cristo, segundo Frazer, seria calcado no modelo dos ritos de vegetação ${ }^{56}$. Esse conjunto simbólico, que integra a Paixão e os ciclos naturais, constituía uma das referências constantes do pensamento de Mário, e marca profundamente a primeira e a última de suas obras poéticas: Há uma gota de sangue e Café.

Em Há uma gota de sangue, a relação entre rito cristão e ritmo natural, além de se verificar nas imagens dos poemas, organiza a própria estrutura geral da obra. Conforme dito, o livro se compõe como um ritual, de modo que a disposição dos poemas não é fortuita, assim como ocorre em outros livros de poesia de Mário, ordenados segundo uma lógica rigorosa. Em primeiro lugar, como todo rito, Há uma gota se inicia, vimos, com uma série de quatro estações preliminares, ou ritos de limiar, que preparam o leitor para a entrada na obra: o pacto de sangue selado na capa do livro e a apresentação da vítima expiatória, examinados nas páginas anteriores; uma exposição das razões do ritual e um prefácio mágico, ainda por estudar. Em seguida, novamente à semelhança dos ritos mágico-religiosos em geral, o poema que abre o livro consiste em uma invocação - nesse caso, uma invocação em que a paz é exaltada e chamada a socorrer os homens. O poema final, por sua vez, convoca o leitor para uma eucaristia mortal, a ser recebida após a restauração da paz, ou seja, depois de atendidos os rogos feitos no primeiro poema da obra, com o qual o último poema forma portanto um arco. Entretanto, o livro não se encerra sem um curto poema-oferenda, que funciona como um rito de saída - assim como o homem não ingressa no domínio do sagrado sem passar por ritos de entrada, ele também não pode sair da jurisdição do religioso sem praticar ritos de saída.

No conjunto, são treze poemas, como são treze os participantes da Última Ceia de Páscoa, quando Cristo, às vésperas da crucifixão, institui o sacramento da eucaristia, afirma que o pão é seu corpo e o vinho, seu sangue, e anuncia que padecerá em sacrifício, declarando a "nova aliança” que se operará por meio do derramamento de seu

\footnotetext{
${ }^{56}$ Frazer, James George. Le Rameau d'Or, Paris: Robert Laffont, 1981.
} 
sangue, vertido para remir os pecados dos homens - como se verá, alguns poemas de Há uma gota comparam o livro ou a poesia ao pão, e falam de oferecer livros como pães; assim, o próprio livro de Mário é concebido como uma espécie de pão sagrado, como o corpo mesmo de Cristo. À santa mesa de Há uma gota, não falta o traidor, o Kaiser, no poema "Guilherme", o único em que o eu-lírico indica um culpado pela guerra sem sentido. No centro da obra, como Cristo à mesa, o poema "Primavera", que descreve a conversão religiosa de um canhão abandonado, conversão que se realiza à medida que ele é coberto pela vegetação que renasce florida. Ora, é o sacrifício do eulírico que propicia, no sistema simbólico de Há uma gota, essa conversão, isto é, a cessação da guerra e o restabelecimento da paz sob a forma do advento da primavera.

O princípio da renovação da natureza encontra-se, portanto, no centro do rito sacrificial estruturado e realizado em Há uma gota de sangue; nesse sentido, ao mesmo tempo em que procura suscitar a ressurreição da vegetação, o rito é também pautado pelo ritmo natural, de forma que, no limite, ele é esse ritmo mesmo. Por sua vez, o movimento cíclico da natureza se configura na obra como um processo ritualístico. Como disse Telê Porto Ancona Lopez, os poemas de Há uma gota de sangue não raro representam uma espécie de "liturgia da natureza", em que o amanhecer, os ventos, os ciclos das estações etc. aparecem como partes de uma grande missa celebrada pelo mundo natural. Assim, em "Inverno", que retrata a paisagem desoladora onde se combinam as imagens invernais e a extinção universal da vida provocada pela guerra, "O vento reza um cantochão...". No poema "Primavera", citado acima, o canhão abandonado "Tem a benção do luar, nas noites perfumosas", "Vem ungi-lo às manhãs o Sol de Abril"; por fim, convertido, "na imota unção de seu catolicismo,/ ouve o "Te Deum' das abelhas sobre as rosas". Em "Espasmo", que descreve a agonia de um soldado alemão ferido de morte, sozinho nos campos, a aurora é descrita sob o prisma do canto dos pássaros: "Sobem aos ares os primeiros hinos,/ num triunfal e transbordante surto". A imagem do "surto", isto é, do êxtase místico dos pássaros e da natureza encontra-se também em "Refrão de obus": "Partir, ouvindo os passarinhos,/ que despertara a cotovia,/ musicar, lado a lado,/ o êxtase florescido dos caminhos!...". 
Inversamente, a ausência do canto dos pássaros associa-se ao silêncio dos sinos da catedral de Reims em "Natal", que não badalam mais o nascimento do Cristo: "Onde estão as canções desabaladas/ dos sinos gárrulos?..." ${ }^{57}$. Em todos esses casos, o leitor terá notado, figura-se a imagem de uma natureza litúrgica, assim como a estrutura de Há uma gota organiza uma espécie de rito natural. Em síntese, rito e natureza correspondem-se na estréia de Mário na poesia, assim como se corresponderão no Café, última obra poética do escritor.

Desse modo, a imagem do renascimento da natureza atravessa Há uma gota de sangue de ponta a ponta. Não por acaso, segundo a "Explicação", mais uma das “estações" preliminares da obra ${ }^{58}$, todos os poemas do livro, não apenas a "Biografia", foram compostos em abril, o mês do advento da primavera na Europa, onde "se passa" todo o livro, como já foi dito - mesmo em São Paulo, onde marca o início do outono, abril também é celebrado por Mário como "o grande mês da natureza na cidade" 59 . De acordo com Mário, os poemas foram escritos "de sopetão", em uma espécie de êxtase criativo, provocado pelo sofrimento que lhe causava "ver homens inimigos entre si": "[os poemas] encegueceram-me por completo", disse o poeta muitos anos depois ${ }^{60}$. Assim como a maior parte das obras poéticas de Mário, portanto, e assim como Macunaíma, Há uma gota de sangue foi composta em um estado semelhante ao transe de possessão, a que Mário não raro se referia como sendo o estado de poesia, em que se produzia um "movimento lírico irreprimível”, como ele costumava dizer. Para ficar em alguns exemplos apenas, foi um "estado sublime selvagem, natureza pura, que ditou

\footnotetext{
57 Andrade, Mário de. Há uma gota de sangue em cada poema, in Obra imatura, Belo Horizonte: Itatiaia, 1980, pp. 9-41. Uma edição mais cuidadosa do livro foi publicada recentemente. Andrade, Mário de. Obra imatura, Rio de Janeiro: Agir, 2009.

58 A colocação exata dessa "Explicação" em prosa é incerta, uma vez que, na primeira edição de Há uma gota, ela se encontrava em folha avulsa, anexa ao livro. De todo modo, as edições sempre a situam, naturalmente, entre os textos preliminares aos poemas da obra.

${ }^{59}$ Andrade, Mário de. “Abril” [1932], in Os filhos da Candinha, Belo Horizonte: Itatiaia, 2006, p. 46.

${ }^{60}$ Em carta de 1935 a Sousa da Silveira. Andrade. Mário de, Mário de Andrade escreve cartas a Alceu, Meyer e outros (coligidas e anotadas por Lygia Fernandes), Rio de Janeiro: Editora do Autor, 1968, pp. $147,159-160$.
} 
Paulicéia", segundo Mário ${ }^{61}$; sobre a série das "Danças", disse o poeta que "em meia hora verdadeiramente aconsciente, estavam escritas as 'Danças', que não sei quem escreveu"62, assim como os poemas do "Carro da Miséria" foram criados "nesse estado de bebedeira integral", de "escritura... mediúnica"63; na mesma linha, Macunaíma redigiu-se "em pleno estado de possessão", em uma "sublimidade que me obnubilava qualquer estado de consciência analítica" 64 ; por fim, Café foi escrito "num mês de entusiasmos e desesperos inconcebíveis"65. A palavra "entusiasmo", aqui, deve ser entendida em seu sentido original, isto é, como o estado em que o sujeito se encontra possuído pela divindade. Embora Mário não tivesse um processo único de criação, tendo inclusive várias vezes defendido a produção literária como construção consciente, o enthousiasmós é o estado criativo por excelência na produção artística do escritor, em especial no campo da lírica: "Sou incapaz de sentar e escrever coisa nenhuma (em poesia) sem já estar fatalizado para isso", escreve Mário a Drummond, em carta de 1944, ao comentar o processo de criação da Lira paulistana, "a 'louca' que provocou a Lira", como ele diz ${ }^{66}$. Um mês depois, Mário volta a descrever seus processos de criação poética, e afirma: "Eu não tenho, como certos escritores dizem ter, pelo menos ‘dizem', um processo único de criação artística. A não ser isso: estar fatalizado, ser mandado por qualquer coisa que eu não sei bem o que é, que independe de mim, que é superior a mim, e me manda, e sou obrigado a obedecer" ${ }^{\prime 67}$.

\footnotetext{
${ }^{61}$ Idem. A lição do amigo (anotadas pelo destinatário), Rio de Janeiro: José Olympio, 1982, p. 49. Em outra carta, Mário refere-se de modo análogo ao processo de composição de Paulicéia: "principiei escrevendo frases e poesias num estado palavra que quando recordo ele me parece que o desvairado era mesmo eu. [...] Escrevi feito maluco" Idem. Mário de Andrade escreve cartas a Alceu, Meyer e outros, op. cit., p. 51.

${ }^{62}$ Idem. A lição do amigo, op. cit., p. 13.

${ }^{63}$ Idem. 71 cartas de Mário de Andrade (coligidas e anotadas por Lygia Fernandes), Rio de Janeiro: São José, s/d, p. 85.

64 Idem. Cartas a um jovem escritor e suas respostas (Fernando Sabino, Mário de Andrade), Rio de Janeiro: Record, 2003, p. 32.

${ }^{65}$ Idem. A lição do amigo, op. cit., p. 209.

66 Idem. Ibidem, pp. 226-227.

67 Idem. Ibidem, p. 231. Devo essa citação à professora Maria Augusta Fonseca, a quem agradeço por essa e por outras tantas dicas valiosas.
} 
Não se deve subestimar, contudo, a presença do trabalho na atividade criadora de Mário. De acordo com Antonio Candido, a ação consciente sobre o material constitui a essência mesma da criação poética do escritor: "Não se sente nos seus versos aquela passividade de certos poetas que, transformando-se em registros, deixam a corrente poética passar através deles"68. A poesia de Mário se distingue, segundo o crítico, por uma vontade construtiva que carrega em si mesma a afirmação do indivíduo que organiza a própria obra, dominando as influências exteriores à consciência. Mário, com efeito, advertiu muitas vezes que, após o momento da criação inspirada, segue-se o trabalho de "polir" a registro do "plasma vivo das sensações", como ele diz em Paulicéia desvairada, de modo que são raros os casos, segundo o escritor, de poemas seus publicados na forma como foram concebidos. Não obstante, como notou Roberto Schwarz, expressão e construção - ou, nos termos usado por Mário, "lirismo" e "técnica" - figuram como coisas separadas nas poéticas do escritor, formando uma antítese que o escritor começa a superar somente em alguns de seus ensaios teóricos $\operatorname{tardios}^{69}$. Noutras palavras, a relação entre expressão e construção, ou entre inspiração e trabalho, não é exposta, a rigor, como dialética nas reflexões estéticas de Mário, nas quais a expressão não é vista como uma instância mediada pelo trabalho, mas corrigida por ele, depois de ser registrada de maneira imediata. Nesse quadro, o trabalho é anterior e posterior à expressão poética do sujeito, mas não simultâneo a ela; ele é externo, e não interno, a ela ${ }^{70}$.

O pensamento marioandradino se diferencia, nesse ponto, de uma das principais constantes estruturais da poesia moderna. Com efeito, embora muitos dos grandes poetas europeus, entre meados do século XIX e os inícios do século XX, tenham incorporado em profundidade à sua produção literária, como formas de negação da ratio burguesa, as "iluminações", o êxtase místico e outros fenômenos mágico-religiosos similares, sempre submeteram essa dimensão de suas obras, de forma verdadeiramente

\footnotetext{
${ }^{68}$ Candido, Antonio. "Mário de Andrade: Poesias" [1941] in Revista do Instituto de Estudos Brasileiros, no 36, São Paulo: IEB/USP, 1994,

${ }^{69}$ Schwarz, Roberto. "O psicologismo na poética de Mário de Andrade”, in op. cit..

70 Sobre a dialética entre expressão e construção na arte, ver Adorno Theodor W. Teoria Estética, Lisboa: Edições 70, 2000, pp. 119-138.
} 
radical, às mediações do trabalho, da razão, da técnica e da linguagem ${ }^{71}$. Salvo engano, pode-se mesmo afirmar que uma das linhas-mestras da poesia moderna, de acordo com o estudo clássico de Friedrich, consiste justamente na dialética, que preside a elaboração dos poemas e neles se sedimenta, entre a magia antiga e a razão moderna, entre o êxtase místico e a reflexão calculada, entre a transcendência e o trabalho intelectual $^{72}$. Desse modo, esses poetas não deixam de aproximar-se de certa experiência religiosa, oposta à do "sagrado selvagem", na expressão de Bastide ${ }^{73}$, e semelhante à "mística legítima" que Auerbach encontra no trabalho literário de Flaubert: uma "mística que repousa, na prática, como todo verdadeiro misticismo, sobre a razão, a experiência e a disciplina"74. Nessa ascese, constitutiva do trabalho poético de Mallarmé, por exemplo, é decisiva a presença do elemento da mediação, que para Hegel aproxima a religião do trabalho ${ }^{75}$ e distingue as "religiões da individualidade espiritual" das "religiões da natureza", as quais, por sua vez, teriam como fundamento, segundo o filósofo alemão, a identidade imediata com o Absoluto ${ }^{76}$. Assim, Rimbaud, que "sonha dar o bote do animal feroz sobre o homem do Ocidente" ${ }^{77}$, e que incorpora, nessa linha, de modo mais profundo do que qualquer outro poeta moderno à sua altura, as experiências religiosas "selvagens", Rimbaud o demiurgo, o vidente satânico, dionisíaco, o poeta que mobiliza a barbárie primitiva contra a barbárie burguesa e contra

\footnotetext{
${ }^{71}$ Raymond, Marcel. De Baudelaire ao Surrealismo, São Paulo: Edusp, 1997, pp. 11-37.

${ }^{72}$ Friedrich, Hugo. Structure de la poésie moderne, Paris: Poche, 2004.

${ }^{73}$ Bastide, Roger. O sagrado selvagem, São Paulo: Companhia das Letras, 2006, pp. 250-275.

${ }^{74}$ Auerbach, Erich. Mimesis, Paris: Perspectiva, 2001, p. 436. A grande poesia moderna, contudo, assim como a prosa de Flaubert, não se converte afinal em mistificação, muito ao contrário; uma vez que a transcendência que ela opera, como diz Friedrich, é uma "transcendência vazia", essa poesia se configura como uma imagem negativa da opacidade do sentido no apogeu do mundo burguês desencantado, isto é, de uma realidade cada vez mais fragmentada e marcada pela alienação. Nesse sentido, escreve Adorno sobre a lírica: "Seu distanciamento da mera existência torna-se a medida do que há nesta de falso e de ruim. [...] A idiossincrasia do espírito lírico contra a prepotência das coisas é uma forma de reação à coisificação do mundo, à dominação das mercadorias sobre os homens, que se propagou desde o início da Era Moderna e que, desde a Revolução Industrial, desdobrou-se em força dominante da vida". Comentando essa reflexão, conclui Berardinelli: "O que distancia e opõe mundo poético e mundo real é também o que os enlaça em um vínculo mortal". Adorno, Theodor W. "Palestra sobre lírica e sociedade", in Notas deliteratura I, São Paulo: Duas Cidades/ Editora 34, 2003, p. 69. Berardinelli, Alfonso. "As muitas vozes da poesia moderna", in Da poesia à prosa, São Paulo: CosacNaify, 2007, p. 36.
}

${ }^{75}$ Hegel, G. W. F. Fenomenologia do Espírito, Petrópolis: Vozes, 2003, pp. 151-171.

${ }^{76}$ Idem. Leçons sur la philosophie de la religion, II, 2, Paris: Vrin, 1972, p. 8.

77 Raymond, Marcel. De Baudelaire ao Surrealismo, op. cit., p. 31. 
a hipocrisia do catolicismo, o poeta que opera a "passagem brutal" da poesia para o surreal, desenvolve o seu misticismo demoníaco por meio da mediação racional e não obtém suas "visões" senão pela prática de um método rigoroso. Na mesma linha, embora de forma muito diferente, as noções de "mistério" e de "magia verbal" são propriamente constitutivas da poética de Mallarmé, mas são dominadas por uma espécie de "hiperconsciência", que as disciplina e integra ao campo da razão: "Mallarmé jamais fala de 'inspiração' [...]. Ele fala de seu 'laboratório', da 'geometria das frases'; ele supervisiona essa poesia altamente 'especializada' com o mesmo senso de responsabilidade que um técnico, um técnico do intelecto e da magia verbal. Seu canto é a obra de uma fria mestria. [...] Ele sempre disse que a poesia é algo muito diferente do entusiasmo e do delírio, e que ela é antes um trabalho preciso de elaboração operado sobre as palavras"78.

Para nós, é significativo que Mário, no grande ensaio em que procura corrigir os excessos do desvairismo defendidos em Paulicéia desvairada e enfatizar a importância da "inteligência" e do trabalho na criação poética, proclame em letras maiúsculas: "É PRECISO EVITAR MALLARMÉ!'79. O pecado capital do prêtre, segundo o autor das "Danças", é a "intelectualização exagerada, forçada", de sua arte: "Mallarmé tinha o que chamaremos sensações por analogias. Nada de novo. Poetas de todas as épocas as tiveram. Mas Mallarmé, percebida a analogia inicial, abandonava a sensação, o lirismo, preocupando-se unicamente com a analogia criada. Contava-a e o que é pior desenvolvia-a intelectualmente obtendo assim enigmas que são jóias de factura mas desprovidos muitas vezes de lirismo e sentimento. [...] Inegavelmente com esse processo de desenvolver pela inteligência a imagem inicial, com estar sempre ao lado do sentimento em contínuas analogias e perífrases a obra de Mallarmé apresenta um aspecto de coisa falsa, de preciosismo, muito pouco aceitável para a sinceridade sem vergonha dos modernistas. [...] Mallarmé desenvolvia friamente, intelectualmente a analogia primeira produzida pela sensação”. Em seguida, em contraponto, Mário lembra

\footnotetext{
${ }^{78}$ Friedrich, Hugo. Structure de la poésie moderne, op. cit., pp. 154, 160.

${ }^{79}$ Andrade, Mário de. A escrava que não é Isaura, in Obra imatura, op. cit., p. 241, grifo do autor.
} 
Cocteau e reafirma o esquema desvairista que ele procurara, ao escrever $A$ escrava, relativizar: "Mallarmé caminha por associações de idéias conscientes, provocadas. Cocteau deixa-se levar cismativamente por associações alucinatórias originadas da imagem produzida pela primeira sensação. Associações alucinatórias provocadas por uma razão que deixa de reagir, subitânea obnubilação a que a personalidade se entrega exausta" $"$. Mesmo n'A escrava que não é Isaura, portanto, onde Mário concede maior importância ao trabalho artístico no processo da produção literária, a expressão dos "instantes de eclipse intelectual", embora trabalhada pela "inteligência", continua a ocupar o centro da poética do escritor. Não por acaso, ao concluir a primeira parte do ensaio, Mário sintetiza os dois princípios da Poesia: a "liberdade do subconsciente" e a "renovação da sacra fúria".

A posição anti-racional de Mário deve ser entendida, decerto, no contexto da negação romântica - no sentido que Michel Löwi dá ao termo, isto é, como uma visão de mundo fundada na oposição radical ao mundo burguês moderno ${ }^{81}$ - do racionalismo abstrato proposta por alguns dos movimentos de vanguarda. Não obstante, mesmo depois de ultrapassada a sua fase "vanguardista", o dionisismo nunca deixaria de constituir o princípio de composição por excelência de sua lírica. A criação poética de Mário se afasta, portanto, do caráter apolíneo, ou do "pathos da distância", como disse Adorno $^{82}$, que marca boa parte da poesia do século XX, segundo a teoria de Friedrich: "A poesia moderna tornou-se um caso de fria meditação, $[\ldots]$ que lhe permite sobrelevar a espontaneidade bruta e o caos das idéias súbitas. [...] O artista se torna o tipo superior do Homo faber. Seu deus é Apolo, não Dioniso"83.

Afasta-se, porém, de um modo bastante singular, pois embora o entusiasmo se encontre no centro da poética marioandradina, há muito trabalho, conforme dito, na

\footnotetext{
${ }^{80}$ Idem. Ibidem, p. 242, grifo do autor.

${ }^{81}$ Löwi, Michel; Sayre, Robert. Révolte et mélancolie: le romantisme à contre-courant de la modernité, Paris: Payot, 2005.

${ }^{82}$ Adorno, Theodor W. "Palestra sobre lírica e sociedade”, in Notas deliteratura I, op. cit., p. 66.

83 Embora deva ser relativizada em certa medida, a teoria de Friedrich preserva, a meu ver, em grande parte, o seu valor. Friedrich, Hugo. Structure de la poésie moderne, op. cit., pp. 229-235. Para uma crítica ao livro de Friedrich, ver Berardinelli, Alfonso. "As muitas vozes da poesia moderna", in Da poesia à prosa, op. cit., pp. 17-41.
} 
produção literária de Mário. Mais do que isso, quem entra em contato com o conjunto da obra de Mário percebe que ela é o resultado de um excesso de trabalho, ou de um trabalho desmedido, realizado até o limite, por assim dizer, das possibilidades individuais. Os momentos de criação das grandes obras de Mário são em geral precedidos de uma acumulação de conhecimento propriamente enorme, como nos casos de Paulicéia desvairada, Macunaíma e Café. Cada uma a seu modo, essas obras surgem sempre sob a forma de uma explosão em que culmina uma preparação exaustiva. Noutras palavras, o trabalho, em sua exacerbação superlativa, "resolve-se" no transe dionisíaco, cujo modelo, como se sabe, é nucleado pelo sacrifício. Segundo esse movimento, o trabalho, apesar de todos os esforços do escritor, não pode consumar-se senão por meio de sua abolição em formas mágico-religiosas que suprimem, em todos os seus níveis, o elemento da mediação, que está no cerne da noção de trabalho.

Ora, uma vez que essa noção possui um vínculo estreito com a noção moderna de sujeito, na base do processo criativo de Mário estão os conhecidos entraves históricosociais à formação da subjetividade no Brasil, decorrentes da combinação de capitalismo e escravidão que modelou a sociedade brasileira desde a constituição do país $^{84}$. No caso de um intelectual como Mário de Andrade, aferrado a um projeto de formação individual - e coletiva -, e disposto como poucos para o trabalho - "Vida de trabalho brabo, vida de todo dia", diz o eu-lírico de um de seus poemas ${ }^{85}$-, as contradições envolvidas no processo de constituição da subjetividade no Brasil se acirram ao extremo, revelando-se de maneira dramática. Assim, uma sujetividade dotada não apenas de uma exigência formativa obstinada, mas também de uma ambição "fáustica" de que sua formação tenha uma abrangência máxima, deparando uma realidade que não permite a realização regular dessas pretensões, intensifica a sua demanda e procura expandir-se em escala superlativa, de modo que, nessa aspiração extrema, não pode formar-se senão por meio de sua própria supressão. Pense-se, nessa

\footnotetext{
${ }^{84} \mathrm{O}$ estudo clássico das relações entre a ausência de uma ética do trabalho, a precariedade do princípio de individuação e as origens rurais e escravistas da sociedade brasileira foi realizado por Ségio Buarque Holanda em Raizes do Brasil, São Paulo: Companhia das Letras, 2002.

${ }^{85}$ Andrade, Mário de. "Louvação matinal”, in Poesias completas, op. cit., p. 256.
} 
linha, na quantidade e na amplitude descomunais do trabalho de Mário de Andrade, e ao mesmo tempo em como esse trabalho encontra a sua consumação nos momentos dionisíacos e sacrificiais, isto é, nos quais o indivíduo se aniquila por completo. Tudo se passa como se a constituição da subjetividade - assim como as idéias burguesas no Brasil, como disse Roberto Schwarz - fosse ao mesmo tempo indescartável e impraticável ${ }^{86}$.

O leitor terá notado que esse movimento é uma configuração do regime complexo e paradoxal da formação supressiva, teorizado por José Antonio Pasta Júnior, mencionado anteriormente. Com efeito, vimos que a formação supressiva constitui um modelo em que o sujeito vem a ser passando no seu outro, ou seja, ele vem a ser deixando de ser, por meio do não ser - ele se forma, em suma, suprimindo a si mesmo. Todavia, é preciso observar, como diz Pasta, que "essa anulação ou consunção da subjetividade" não se dá por "falecerem as forças próprias" do sujeito, ao contrário: “esse sujeito desaparece não por anêmico, mas por pletórico, 'morre' por excesso de potência, não por fraqueza"; assim, a subjetividade, "expandindo-se desmedidamente, desdobra-se no 'objeto absoluto', a totalidade autônoma que, justamente, vem apagála"87. Daí, mostra o crítico, as afinidades que até certo ponto existem entre esse sujeito e o Fausto da primeira parte da tragédia de Goethe, uma vez que ambos desejam o Absoluto e, para obtê-lo, como de regra nesses casos, "perdem" sua alma; Fausto, porém, resgata-se na segunda parte do drama por meio da ética do trabalho e da renúncia, ao passo que os heróis das nossas letras, e muitos de nossos autores, afirma Pasta, lançam-se em operações mágico-religiosas que implicam a desaparição da subjetividade na referida "totalidade autônoma", isto é, no mito.

Como temos visto, na criação da poesia de Mário, essas operações, precedidas de uma desmedida acumulação de conhecimento, ou seja, de uma quantidade imensa de pesquisa e de trabalho, assumem sobretudo a forma do transe, cuja estrutura é sacrificial - com efeito, a formação supressiva, diz Pasta, se consuma por meio de um sacrifício,

\footnotetext{
${ }^{86}$ Schwarz, Roberto. Ao vencedor as batatas, São Paulo: Duas Cidades/Editora 34, 2000, p. 26.

${ }^{87}$ Pasta Júnior, José Antonio. Pompéia: a metafísica ruinosa d’O Ateneu, op. cit., p. 71.
} 
como disse o crítico a respeito de Macunaíma: "Herói brasileiro, ele foi ainda uma vez e não a última - chamado a realizar o impossível - fazer com que o movimento seja a imobilidade, o mesmo, o outro, e o ser, o não-ser. Ele o fez - como de rigor - pela autoimolação sacrificial, conforme o cruento rito nacional da formação supressiva" 88 . Assim, apesar do preparo e da intenção de escrever, a produção literária não se realiza senão nos "instantes de vacuidade em que há como que um eclipse quase total da reação intelectual”, como diz Mário ${ }^{89}$, ou seja, nos momentos de entusiasmo, de possessão. Ao comentar as dificuldades que enfrentava para escrever um poema já ideado, Mário diz a Bandeira: “A 'Louvação do meu Estado natal' que eu tenho inteirinha dentro de mim, que sei de cor nas idéias, que escuto... não consigo ver, não tem forma, não tem nenhum verso escrito e me parece impossível de escrever. Tenho percorrido toda a escala de metrificações existentes, metrificações qualitativas, quantitativas e até a por acentos dos hinógrafos bizantinos nada se adapta à 'Louvação'. Só o verso livre às vezes me parece plausível. Porém outras me parece impossível inajustável com idéias tão serenas, enfim, um horror. [...] A minha parte do poema está pronta. Falta aquela 'parte de Deus'. [...] Deus inda não veio"90. Conforme dito, o trabalho, nesse quadro, é sobretudo anterior e posterior à composição, mas não é propriamente a mediação da criação poética; ao contrário, a escrita se dá quando as mediações ou distâncias estéticas - entre autor e

88 Idem. "Tristes estrelas da Ursa - Macunaíma", in Cadernos Porto \& Vírgula, $\mathrm{n}^{\circ}$ 4, Porto Alegre: Secretaria Municipal de Cultura, 1993, p. 32.

${ }^{89}$ Andrade, Mário de. A escrava que não é Isaura, in op. cit., p. 255.

90 Idem. Correspondência - Mário de Andrade \& Manuel Bandeira (org. Marcos Antonio de Moraes), São Paulo: Edusp/IEB, 2000, p. 234. No mesmo sentido, descrevendo o longo tempo decorrido entre a concepção e a escrita de um poema da Lira paulistana, Mário diz a Drummond: "Como sempre faço, quando tenho a idéia dum poema, tomo nota em caderno [...], tomo nota e fico esperando que a coisa venha". Na carta seguinte ao poeta mineiro, escreve de modo análago: “Às vezes o mando vem com a idéia e a coisa se cria imediatamente. E às vezes espero, espero, e a coisa dura muitos anos pra chegar. Como o Café ideado por 1933 e que só chegou em outubro de 42". A história da criação de Café ilustra bem o processo que estamos definindo. Como se sabe, Mário projetou, primeiro, um romance sobre o tema, e trabalhou nessa obra, de forma intermitente, ao longo de mais de uma década; durante esse período, em 1933, como ele disse, "veio de sopetão", após muitas reflexões sobre o problema do teatro cantado, a idéia de compor uma ópera, não um romance, sobre o assunto; a idéia, porém, somente frutifica em 1942, em um momento em que o trabalho acumulado, exasperando-se, converte-se em transe criativo: "Trabalhei que não foi vida. Mas foi sublime, vinha tudo fácil, minha cabeça fagulhava de invenções felizes. Escrevi tudo", escreve Mário a Paulo Duarte em 1942. "Trabalhei três meses, de iluminações sublimes e desesperos impiedoso, nele", diz a Antonio Candido no ano seguinte. Em carta a Drummond da mesma época, vimos, Mário afirma que a criação foi ainda mais curto: "num mês de entusiasmos e desesperos inconcebíveis". As citações acima encontram-se em Andrade, Mário de. A lição do amigo, op. cit., pp. 209, 226, 232. Idem. 71 cartas de Mário de Andrade, p. 58. Duarte, Paulo. Mário de Andrade por ele mesmo, São Paulo: Hucitec, 1977, p. 254. 
obra, linguagem e realidade etc. - são suprimidas, o que é efetivado no transe e no sacrifício, que são, ambas, operações nucleadas pela anulação da distância, em todos os níveis, entre o mesmo e o outro. O trabalho "crítico", como dizia Mário, "acrescenta, elimina, adapta, modifica", mas sempre depois que "o lirismo puro é grafado com o mínimo de desenvolvimento que sobre ele possa praticar a inteligência", pois a razão não pode "quebrar o êxtase" "91 . "O pensamento crítico mata sempre o estado de poesia", escreve Mário a Drummond em 1944, portanto no final da vida, o que mostra que esse processo criativo bastante peculiar não se limita à produção de juventude do escritor ${ }^{92}$.

Voltando a Há uma gota de sangue em cada poema, vimos que o êxtase criativo em que se compôs a obra ocorreu em abril, como afirma o próprio Mário de Andrade na "Explicação" que antecede os poemas do livro. Esse fato não teria importância para o crítico, não fosse Há uma gota uma obra em que a distância entre o autor e a poesia tende a ser suprimida, conforme dissemos ao analisar a capa do livro. Assim como os elementos gráficos que ilustram as páginas, as condições de criação da "estréia poética" de Mário participam do significado profundo da obra, de modo que o seu estudo contribui de maneira decisiva para revelar esse significado. Nessa linha, vale notar que o êxtase de criação de Há uma gota relaciona-se ao êxtase da natureza que renasce, que constitui uma das imagens essenciais do livro, como vimos; assim, em "Primavera", o poema central do conjunto, um canhão, ao ser "convertido", isto é, ao ser integrado à paisagem da natureza primaveril, figura como uma Santa Teresa em êxtase, tal como o grupo de Bernini:

\section{“Converteu-se. Sorriu à natureza; \\ perdoou a rabujice ao vento sul;}

\footnotetext{
${ }^{91}$ Idem. A escrava que não é Isaura, in op. cit., p. 205, 285-286.

92 Idem. A lição do amigo, op. cit., p. 227. Ao tratar da criação de Macunaíma, Cavalcanti Proença resume esse processo produtivo de Mário, considerando-o como uma espécie de "método de trabalho": "Primeiro era a documentação trabalhosa e pachorrenta, para depois escrever. E nenhum trabalho seu deixou de ser documentado escrupulosamente. Desde Macunaíma até muitas poesias. Vinha o momento da criação, o 'estado de poesia', coisa comparável a um transe mediúnico, em que aqueles fragmentos de documentação se integravam e Mário de Andrade redigia. [...] Só depois começava o trabalho de arte, o polimento, o artífice em ação". Proença, M. Cavalcanti. Roteiro de Macunaíma, Rio de Janeiro: Civilização Brasileira, 1978, p. 5.
} 
e, no êxtase imortal - Santa Teresa

da primavera - ele olha esperançosamente,

essa visão seráfica e esplendente,

a claridade mágica do azul..." 93

O êxtase, como se sabe, é uma experiência essencialmente sacrificial; ele corresponde, na tradição católica, que impregna a estrutura e os temas de Há uma gota de sangue, e na qual o êxtase assume a forma que melhor condiz com o seu próprio conceito, ao apogeu da imitatio Christi, que pauta a vida dos místicos. Nesse quadro, o êxtase é algo como a vivência dolorosa e deliciosa do próprio martírio de Cristo, a mimese suprema da Paixão, a união íntima, identificatória, com o Amado em seu sofrimento e em sua transfiguração: "no êxtase, a imobilidade é absoluta; o corpo se paralisa em uma posição, em geral a da crucificação"94; o místico em êxtase configura, portanto, uma "imagem viva do Cristo crucificado", de modo que o êxtase é acompanhado, não raro, de hemorragias: “os fenômenos paramísticos de que o corpo é o lugar assumem a forma de efusões de sangue" - em especial, nos estados mais sublimes, sob a forma dos estigmas. "Tu és para mim um esposo de sangue”, costumava dizer uma santa habituada a esses traspasses, revelando, na formulação, a natureza sacrificial do gozo místico ${ }^{95}$. Como se verá adiante, o ideal da imitatio Christi está na base da concepção de Há uma gota de sangue; "ser grande", diz o eu-lírico em “Guilherme”, "é ter a luz e compreender a luz,/ é ser bom finalmente, é ser Jesus!..."96.

Isso posto, pode-se afirmar que êxtase criativo, sacrifício e primavera convergem na estréia poética de Mário de Andrade. A relação profunda entre esses três elementos está na base do soneto "Prefácio", que constitui o último "rito de entrada" de Há uma gota de sangue, a última estação ritualística preliminar da obra:

\footnotetext{
93 Idem. "Primavera", in Há uma gota de sangue em cada poema, in op. cit., p. 25.

94 Bastide, Roger. Les problèmes de la vie mystique, op. cit., p. 134.

95 Albert, Jean-Pierre. Le sang et le Ciel: les saintes mystiques dans le monde chrétien, op. cit., pp. 202, 327-328

${ }^{96}$ Andrade, Mário de. "Guilherme”, in Há uma gota de sangue em cada poema, in op. cit., p. 30
} 
“Perdão. - Também, no mato, se depara

guarantã que tombou, no último esmaio,

porque, vencido à chuva, o estraçalhara

- Pollice verso! - o gládio irial do raio...

Tombou entre os cipós. E, quando maio

sobre o exício medonho se escancara,

vê que o recobre o riso novo e gaio

das trepadeiras e da manhã clara.

- Por sobre o torso lívido e canhestro

da Europa em ruína vem também agora

brilhar, de manso, o maio em sol dum estro:

deixai, floresçam, nos seus tons diversos,

as rosas matutinas desta flora,

a primavera destes simples versos!"

O caráter ritual do poema se revela desde a primeira palavra. Ao iniciar-se com o pedido de perdão, o discurso assume a forma da prece, que é propriamente um rito, como disse Mauss, uma vez que ela não consiste somente em uma reflexão sobre o sagrado, mas é sobretudo um ato, ou seja, dirige-se a uma divindade e a influencia, esperando obter, desse modo, resultados favoráveis da instância religiosa: "a prece não é um puro devaneio sobre o mito, nem uma pura especulação sobre o dogma, mas implica um dispêndio de energia física e moral com vistas à produção de certos efeitos" ${ }^{\prime 97}$. No "Prefácio" de Há uma gota, o eu-lírico pede perdão pelos crimes dos homens, que fazem a maior guerra de todos os tempos; perdão pelas "mil invejas e ambições" de que

\footnotetext{
${ }^{97}$ Mauss, Marcel. “A prece”, in Ensaios de sociologia, op. cit., p. 269.
} 
brotou "a flor púrpura da guerra", pelo "desvairado matar" em que "mesmo os Abeis tornaram-se Cains", pelas "hecatombes mostruosas", pela "carniçal volúpia das chacinas"98. De certa forma, é como se o eu-lírico dissesse, no "perdão", a primeira das sete palavras do Cristo na cruz - "Pai, perdoai-os, porque eles não sabem o que fazem" -, por meio da qual, de acordo com o evangelho de Lucas, o supliciado roga ao deus que perdoe a ignorância dos que o martirizam 99 . A frase tem como tema, portanto, o "perdão aos inimigos", refletindo uma exortação anterior do Cristo a seus seguidores: "Amai a vossos inimigos" $" 100$.

O "mútuo perdão", justamente, aparece no horizonte de Há uma gota de sangue, de maneira bastante ingênua, como a forma que permitiria encerrar-se a Primeira Guerra Mundial, não fossem os homens dominados por invejas e ambições: "desvairado matar, hecatombes monstruosas/ E de nenhuma parte um beijo de perdão!", lamenta o eu-lírico na "Exaltação da paz". Embora o livro sofra alguma influência do cientificismo que o autor encontrava no unanimismo de Jules Romains, prevalecem amplamente os critérios católicos na reflexão que o eu-lírico faz, no livro, sobre as causas da guerra, que são, segundo essa perspectiva, de ordem moral sobretudo ${ }^{101}$; mesmo quando ensaia expor, no poema "Devastação", uma espécie de "dialética do esclarecimento", em que a história da civilização ocidental é representada, desde as suas origens até a sua liqüidação no século XX, como a história da dominação da natureza pela razão, mesmo nesses versos a catástrofe deve-se ao nascimento, no espírito do homem, no apogeu da Aufklärung, de pecados capitais, como o orgulho, a avareza e a inveja:

\section{“O saber suspicaz penetra o alto segredo \\ da vida. É tudo um labutar de ciência.}

\footnotetext{
98 Os versos e as expressões citadas são dos poemas "Exaltação da paz" e "Devastação". Andrade, Mário de. Há uma gota de sangue em cada poemas, in op. cit., pp. 16-17, 33.

${ }^{99}$ Lucas 23:34, in Bíblia Sagrada - "Novo Testamento", op. cit., p. 117.

${ }^{100}$ Mateus 5:44. Ibidem, p. 10.

101 Sobre a influência da poética unanimista em Há uma gota de sangue em cada poema, ver Lopez, Telê Porto Ancona. Mário de Andrade: ramais e caminho, São Paulo: Duas Cidades, 1972, pp. 21-32; Idem. “A estréia poética de Mário de Andrade", in Mariodeandradiando, São Paulo: Hucitec, 1996, pp. 3-15.
} 
O homem afoita-se, descobre, perde o medo...

- E brilha, altiva e forte, a inteligência.

E ele atinge afinal o cume do Jungfrau.

Olha em redor e vê, na campina tamanha, uma herança que é sua e que se perde além:

e tem um pensamento mau.

Ele atingiu o cume da montanha!

Só ele é grande!

- E o orgulho máximo e insensato brilha.

Vem a rivalidade, a traição, a mentira, o exagero da glória, a negação da falta; $[\ldots]$ e os homens todos, na avareza atroz, ganiram, defendendo os bens, como mastins...

A afeição tresmalhou. E no esterco fecundo de mil invejas e ambições, abrolha a flor púrpura da guerra..." 102

Nesse contexto, como temos visto, o eu-lírico assume a posição da vítima que, por meio de seu sangrento sacrifício, tira os pecados do mundo e dá a paz aos homens. Como o Cristo das cartas de Paulo, o eu-lírico de Há uma gota de sangue exerce a função da vítima que une os povos, que abole a inimizade e pacifica o gênero humano: 
"Vós [os judeus e os gentios], que antes estáveis longe, já pelo sangue de Cristo chegastes perto./ Por que ele é a nossa paz, o qual de ambos os povos fez um; [...] Na sua carne desfez a inimizade"; "Por que foi do agrado do Pai que toda a plenitude nele habitasse./ E que, havendo por ele feito a paz pelo sangue da sua cruz, por meio dele reconciliasse consigo mesmo todas as coisas"103. Vale lembrar que Mário, à época da composição de Há uma gota de sangue, era congregado mariano e tinha o cristianismo como modelo de vida; alguns anos antes, em 1913, recebera de presente de seu irmão mais velho a Imitação de Cristo, conhecido livro devocional do século $\mathrm{XV}$, atribuído a Thomas de Kempis, e que Mário leu e anotou.

Isso posto, voltando ao "Prefácio" de Há uma gota, não é à toa que o leitor depare, em seguida ao pedido de perdão feito na abertura do poema, uma imagem sacrificial em contexto brasileiro: "Perdão. - Também, no mato, se depara/ guarantã que tombou, no último esmaio,/ porque, vencido à chuva, o estraçalhara/ - Pollice verso! - o gládio irial do raio...”. Os elementos nacionais da imagem são o guarantã - uma árvore nativa do Brasil, encontrada especialmente na Mata Atlântica e no interior de São Paulo - e o "mato", termo com que Mário sempre se referiu à vegetação brasileira ${ }^{104}$. A cena representada na primeira estrofe do poema, portanto, se passa no Brasil. No entanto, a imagem do guarantã tombado, fulminado por um raio, corresponde à imagem, desenvolvida no poema "Espasmo", do soldado em agonia, estendido nos campos desertos depois de uma batalha. Com efeito, a árvore que jaz no mato encontra-se "no último esmaio", depois de ter sido ferida, como em um combate, pelo "gládio irial do raio". Compreende-se, desse modo, o "também" que inicia a frase: "também no Brasil se depara a imagem funesta que se vê nos campos da Europa em guerra", dizem os versos. Existe contudo uma diferença essencial, ligada ao sentido profundo do livro,

\footnotetext{
${ }^{103}$ Efésios, 2:13-15; Colossenses, 1:19-20, in Bíblia Sagrada, op. cit., pp. 248, 258, grifo meu.

104 Lembre-se da célebre frase de abertura de Macunaíma: "No fundo do mato-virgem nasceu Macunaíma, herói de nossa gente". Em uma carta de 1923 a Tarsila, alerta a pintora, que se encontra em Paris, para os riscos da influência cultural européia, instando-a a voltar ao Brasil e desenvolver uma pintura brasileira: "Abandona Paris! Tarsila! Tarsila! Vem para a mata-virgem”. Andrade, Mário de. Correspondência - Mário de Andrade \& Tarsila do Amaral (org. Aracy Amaral), São Paulo: Edusp/IEB, 2001, p. 79, grifo meu.
} 
entre as duas cenas: a primeira retrata um fato natural; a segunda, um fato histórico ${ }^{105}$. A natureza mimetiza a guerra dos homens, a catástrofe histórica ocorre também sob a forma da catástrofe da natureza - um esquema que Mário retoma em Café, onde a grande crise do capital é também a morte do princípio da vegetação.

Vimos que o ritmo natural, em Há uma gota de sangue, associa-se à operação sacrificial, de fundo cristão, que está na base da obra. Não por acaso, a morte do guarantã, na primeira estrofe do "Prefácio", configura-se também como um sacrifício. A árvore "tomba", conforme dito, em um contexto de combate: primeiro, ela é "vencida" pela chuva; em seguida, estraçalhada pelo "gládio" de um raio. Entre a derrota e o golpe mortal, a sentença: Pollice verso! A expressão latina significa "com o polegar invertido, apontado para o solo", e refere-se ao gesto por meio do qual o público, ao final de um duelo entre dois gladiadores, na Roma antiga - lembre-se que o guarantã, no poema de Mário, é ferido pelo "gládio irial do raio" -, determina que o combatente derrotado deve ser morto pelo vencedor. Noutros termos, o gesto denota a recusa, por parte da multidão, de agraciar o gladiador vencido, decretando o sacrifício do perdedor. Pollice verso, em suma, é um gesto sacrificial ${ }^{106}$. O guarantã tombado de Há uma gota constitui, portanto, a imagem da vítima expiatória.

\footnotetext{
105 Vale lembrar que a idéia de que na Europa se encontra a história, ao passo que no Brasil, apenas a natureza, constitui uma espécie de topos do imaginário brasileiro e vincula-se à condição periférica da nação no sistema mundial do capitalismo. A formulação clássica dessa dualidade foi feita por Nabuco, que dela extrai uma contradição mais complexa, ou seja, a divisão íntima entre sentimento e imaginação de que sofre todo brasileiro "desde que temos a menor cultura": "Na América falta à paisagem, à vida, ao horizonte, à arquitetura, a tudo o que nos cerca, o fundo histórico, a perspectiva humana; na Europa nos falta a pátria. [...] O sentimento em nós é brasileiro, a imaginação é européia. [...] Eu sei bem, para não sair do Rio de Janeiro, que não há nada mais encantador à vista do que os parques de São Clemente, o caminho que margeia o aqueduto de Paineiras na direção da Tijuca, a ponta de São João, com o Pão de Açúcar, vista do Flamengo ao cair do sol. Mas tudo isto é ainda, por assim dizer, um trecho do planeta de que a humanidade não tomou posse; é como um paraíso terrestre. [...] No século em que vivemos, o espirito humano, que é um só e terrivelmente centralista, está do outro lado do Atlântico; o Novo Mundo, para tudo o que é imaginação estética ou histórica é uma verdadeira solidão". No início dos anos 1920 , Mário, em plana fase nacionalista, dará a essa ruminação triste, como se verá na segunda parte deste trabalho, o nome de "moléstia de Nabuco", cuja cura, ele dirá, está na dedicação do intelectual brasileiro aos problemas de seu país. Nabuco, Joaquim. Minha formação, Belo Horizonte: Itatiaia, 2004, pp. 58-59, grifo do autor.

106 Não é à toa que Pollice verso [1904] é o título de uma gravura de Norman Lindsay que causou escândalo nos meios cristãos no início do século XX, uma vez que retrata uma multidão de homens e mulheres nus, pagãos, fazendo o gesto pollice verso diante do Cristo crucificado. É improvável que Mário tenha conhecido a obra; não obstante, sua lembrança, aqui, pareceu-me oportuna, quando menos para enfatizar a conotação sacrificial do gesto registrado no "Prefácio" de Há uma gota.
} 
Com efeito, é sobre o seu tronco morto, sobre o seu cadáver, que a natureza renascerá na segunda estrofe do soneto: “Tombou entre os cipós. E, quando maio/ sobre o exício medonho se escancara, / vê que o recobre o riso novo e gaio/ das trepadeiras e da manhã clara". Há uma gota se situa na passagem de abril para maio, portanto do início para o apogeu da primavera, passagem que integrava, para Mário, o complexo sacrificial e simbólico nucleado pelo "princípio místico de morte e ressurreição da natureza”. Nessa linha, em um texto tardio, Mário observa a convergência das nossas danças dramáticas, que em sua maior parte têm esse princípio em seu centro, e a festa portuguesa das Maias, de origem pagã, que celebra a "volta da primavera e a frutificação do vegetal"107. Há uma gota celebra também, como temos visto, a renovação da natureza, e o faz sob forma ritual. Ora, celebrar, além de acolher com festejos, significa também promover, solenemente, o fato festejado; os ritos, diz Mauss, têm "uma verdadeira eficácia material. [...] Determinado sacrifício primaveril contribui, tanto como o amanho das terras [e a mudança de estação, diríamos], para fazer germinar os grãos"108. Assim, dada a relação, que existe em Há uma gota, como vimos, de influência recíproca entre rito agrário e natureza - a natureza condiciona o rito e o rito condiciona a natureza -, o livro não apenas se situa no trânsito para a primavera como procura suscitar o renascimento da vegetação. Esse sentido propiciatório do rito que é Há uma gota de sangue evidencia-se nos dois tercetos do "Prefácio":

“- Por sobre o torso lívido e canhestro

da Europa em ruína vem também agora

brilhar, de manso, o maio em sol dum estro:

deixai, floresçam, nos seus tons diversos, as rosas matutinas desta flora, a primavera destes simples versos!"

\footnotetext{
107 Andrade, Mário de. Danças dramáticas do Brasil, Belo Horizonte: Itatiaia, 2002, pp. 31-70. 
Vimos que o guarantã brasileiro da primeira estrofe do poema constitui uma metáfora do soldado europeu em agonia, estendido sobre os campos desertos. $\mathrm{Na}$ terceira estrofe, ambos, a árvore se compara à própria Europa, ao passo que o soldado, embora não mencionado, encarna a terra natal, o Velho Mundo devastado, numa espécie de metonímia; o cadáver do combatente é o "torso lívido e canhestro da Europa", e a paisagem invernal ("lívida") e arruinada ("canhestra") é o corpo de um soldado morto. Todas contradições européias, portanto, se concentram no corpo mesmo do soldado; ele é o substituto da Europa, ele é a sua vítima expiatória. Com efeito, o regime do sacrifício, de acordo com Lévi Strauss, tem uma "orientação metonímica", isto é, estabelece entre os participantes uma série de identificações sucessivas, portanto uma relação de continuidade, não de semelhança ${ }^{109}$. O sacrifício do soldado na guerra, entretanto, aparece em Há uma gota de sangue como um ato sem sentido; ao longo dos poemas do livro, como disse Telê Ancona Lopez, o eu-lírico faz a "denúncia da inutilidade do sacrifício do soldado"110, tema comum no âmbito da crítica à guerra: "Vão para a guerra, desdenhando-lhe as agruras,/ todos vestidos de coragens ambiciosas:/ acaso alguém terá razão?...", perguntam os versos da "Exaltação da paz"111. Mas embora o tema seja por assim dizer universal, Mário o insere em contexto específico, em contexto sacrificial católico. No lugar do sacrifício sem sentido dos soldados europeus, o eu-lírico oferece o sacrifício ritual de si mesmo, capaz de pôr fim à guerra, assim como Cristo, ao apagar o pecado com o próprio sangue, e não com o sangue dos outros, pretende eliminar, de uma vez por todas, a repetição dos sacrifícios entre os homens ${ }^{112}$.

\footnotetext{
109 Lévi-Strauss, Claude. O pensamento selvagem, op. cit., 248-253.

110 Lopez, Telê Porto Ancona. “A estréia poética de Mário de Andrade”, in op. cit., p. 10.

111 Andrade, Mário de. "Exaltação da paz", in Há uma gota de sangue em cada poema, in op. cit., p. 17. Sobre a aproximação entre as noções da guerra e do sacrifício na Grécia antiga, ver Vernant, Jean-Pierre; Vidal-Naquet, Pierre. "Chasse et sacrifice dans l'Orestie d'Eschyle", in Mythe et tragédie en Grèce ancienne, Paris: La Découverte, 2001, pp. 135-158.
}

112 Herrenschmidt, Olivier. "Sacrifice symbolique ou sacrifice efficace", in op. cit., p. 185. 
Nesse contexto, o "estro" do poeta figura como o "maio em sol" que "vem brilhar" sobre o "tronco lívido" da Europa. Sua natureza sacrificial confere-lhe o poder mágico de propiciar o advento da primavera no hemisfério norte. Não é à toa que o poeta escolhe, portanto, a palavra "estro", em vez de "inspiração" ou "entusiasmo", por exemplo: como se sabe, além de significar o "ímpeto lírico", o "furor poético", o termo refere-se também ao período da fertilidade feminina. Ora, se o estro é o "maio em sol" da Europa, os versos por ele criados são a própria vetegação renascida: “deixai, floresçam, nos seus tons diversos,/ as rosas matutinas desta flora,/ a primavera destes simples versos!"’. O canto do poeta é a própria força de renovação vegetal, pois ele é o próprio sangue do poeta sacrificado, o sangue purificado pelo sacrifício e, por isso, revivescente.

Canto - ou música - e natureza associam-se com freqüência nos poemas de $H a ́$ um gota, na maioria das vezes em contexto de celebração religiosa. "De novo os cantos rolarão nos prados;/ e os homens todos rezarão aos céus, numa ressurreição da esperança e da crença!", exclama o eu-lírico ao final da invocação, de nítida feição mágico-religiosa, dirigida à "divina paz", logo no poema de abertura do livro ${ }^{113}$. No "Refrão de obus", poema carregado de ironia grandiloqüente, a trajetória de uma bomba contrasta com a renovação musical e religiosa da natureza: "Partir, ouvindo os passarinhos,/ que despertara a cotovia,/ musicar, lado a lado,/ o êxtase florescido dos caminhos!.../ [...] à ovação triunfal do dia infante e lindo"114. Um contraste semelhante se observa em "Primavera", nos versos, citados acima, que descrevem a conversão de um canhão abandonado nos campos: "Cobre-lhe uma roseira o desnudo cinismo./ Tem a bênção do luar, nas noites perfumosas./ Vem ungi-lo às manhãs o Sol de Abril./ E o canhão convertido, odorante e gentil,/ na imota unção de seu catolicismo,/ ouve o 'Te Deum' das abelhas sobre as rosas"115. Essa oposição flagrante entre o horror da guerra e a alegria do mundo natural que renasce se exacerba em "Espasmo", cujos versos, como

\footnotetext{
113 Andrade, Mário de. "Exaltação da paz", in Há uma gota de sangue em cada poema, in op. cit., p. 18, grifos meus.

${ }^{114}$ Idem. "Refrão de obus", in op. cit., p. 23, grifos meus.

${ }^{115}$ Idem. "Primavera", in op. cit., p. 26, grifos meus.
} 
vimos, narram a agonia de um soldado alemão; este está prestes a expirar quando nasce a manhã: "E os passarinhos riem desumanos.../ Sobem aos ares os primeiros hinos,/ num triunfal e transbordante surto; e em cima dele [ou seja, do soldado], com seus pios cristalinos,/ libra uma cotovia o vôo curto..."116. Por fim, o sarcástico "Os carnívoros", poema que encerra o livro convidando o leitor à realização de uma eucaristia sinistra, como se verá, inicia-se todavia ingênuo: “Quando a paz vier de novo, nova e franca,/ passar nestas estradas e caminhos,/ novas aves e novos ninhos/ hão-de agitar-se pela manhã branca.../ [...] Virão novas colheitas,/ [...] virão as noites de bailados e cantigas!..."117.

À vista disso, pode-se dizer que há, também, uma "gota" de música em cada poema do livro. Sangue, natureza e música têm as mesmas essências em Há uma gota. Não por acaso - lembre-se que o sangue, em contexto mágico-religioso, tem as propriedades contraditórias do remédio e do veneno -, Mário considerava a música uma espécie de pharmakós: “A música é assimilável a certas substâncias que, em dose baixa, são agentes higiênicos, em maior dose remédios ativos, e em maior quantidade tóxicos violentos"118. As forças da música, em sua ambivalência inclusive, são análogas às do sacrifício sangrento. No Agamêmnon, de Ésquilo, o poder exercido pelo sacrifício sobre as forças naturais é comparado àquele exercido pela música sobre a natureza: "assim como Orfeu encantava os animais por meio de sua música, por meio de um sacrifício humano encantam-se os ventos da Trácia"119. No âmbito mágico-religioso, sangue e música possuem afinidades eletivas. Assim como o sacrifício, diz Jacques Attali, a música organiza a violência e, por isso mesmo, a elimina, convertendo-a em seu contrário, isto é, em vida; a música dá forma ao ruído, confere-lhe um sentido: "Escutar um ruído é como ser ameaçado de morte. Escutar música, por sua vez, é como assistir a

\footnotetext{
116 Idem. "Espasmo", in op. cit., p. 28.

${ }^{117}$ Idem. "Os carnívoros", in op. cit., p. 38.

${ }^{118}$ Idem. "Terapêutica musical”, in Namoros com a medicina, Belo Horizonte: Itatiaia, 1980, p. 51.

119 Moutsopoulos, Evanghélos. La philosophie de la musique dans la dramaturgie antique: formation et structure, Paris: Vrin, 1999, p. 19. A passagem de Agamêmnon encontra-se no v. 1418, quando Clitemnestra lamenta a imolação de Ifigênia praticada por Agamêmnon: "Ele sacrificou sua própria filha, a menina querida a que dei à luz com tanta dor, para encantar os ventos da Trácia".
} 
um assassinato ritual"'120. Da mesma forma que o sacrifício, contudo, a música opera num limite; ao escapar do controle, como o sangue da vítima, a música dissemina a catástrofe, enlouquece os homens, como bem sabia Platão, para quem a música devia ser racionalizada com rigor, diríamos, espartano ${ }^{121}$. Na obra - e em especial na lírica de Mário, como se verá na terceira parte deste trabalho, a música dionisíaca e selvagem, que a reflexão platônica repudia, ocupa um lugar central; nela, o escritor espera encontrar uma mediação extrema que organize, na esfera literária ou teórica, as relações entre sujeito e objeto, indivíduo e sociedade, linguagem e matéria histórica, obra e leitor, entre outras. Em Há uma gota de sangue, porém, embora a Dioniso esteja profundamente ligado o princípio da renovação da vegetação ${ }^{122}$, a música, não obstante extática, é a expressão luminosa da natureza pacificada.

Nos poemas do livro, a música é representada como um movimento ascensional no ar, dirigido pela natureza ao céu divino, ou seja, a música é a sublimação do sangue, o sagrado volatilizado, o sagrado na forma da voz. Não por acaso, ela se associa, em $H a ́$ uma gota, ao perfume. Na tradição mística cristã, o sangue de Cristo é concebido como uma substância aromática; o perfume, nesse caso, representa o próprio sangue de Cristo sublimado, e a exalação de aromas agradáveis equivale à efusão sangüínea de uma imitatio Christi ${ }^{123}$. O perfume é o fumo da vítima expiatória perfeita. Assim, no complexo sacrificial de Há uma gota, em que o sangue, a música e a renovação da natureza se identificam, o perfume aparece como uma espécie de emanação musical do mundo vegetal. No "Epitalâmio", que narra o passeio matinal de dois amantes, um soldado alemão ferido e uma francesa, pelos jardins de um hospital, a relação entre o sangue, a música, a natureza e o perfume se sugere, em oposição ao combate sem sentido, que mutila o homem e transforma os hinos nupciais em uma cruel ironia, uma

\footnotetext{
120 Attali, Jacques. Bruits, Paris: Fayard/Puf, 2001, p. 52.

121 Moutsopoulos, Evanghélos. La musique dans l'oeuvre de Platon, Paris: PUF, 1989.

122 Jeanmaire, Henri. Dionysos: histoire du culte de Bacchus, Paris: Payot, 1991, pp. 5-56.

123 Albert, Jean-Pierre. Le sang et le Ciel: les saintes mystiques dans le monde chrétien, op. cit., pp. 183-200.
} 
vez que eles se destinam, entre outras coisas, a garantir a fertilidade do casamento, ao passo que na guerra não há casamento, nem o amor dá seus frutos ${ }^{124}$ :

“É sempre assim. De manhãzinha, braço dado, nos jardins claros do hospital, ele mancando, a ela apoiado, silneciosos, lado a lado, dão o passeio matinal.

E, vagarosamente, se entranhando no perfume vermelho da manhã, ela vem triste - ela, que é sã e ele, - o ferido - traz sorrisos francos, vem assobiando entre seus lábios brancos uma valsa alemã...

E no fundo do parque redolente, onde tudo é perfume e som, sentam-se e dizem, já maquinalmente: 'Êtes vous las?' - 'Oh! non!’” 125

$\mathrm{Na}$ atmosfera de tristeza que impregna os versos do poema, a palavra "redolente", que qualifica o jardim do hospital, concentra uma ambigüidade semântica bastante reveladora: ao mesmo tempo em que significa "de aroma agradável; oloroso, rescendente, perfumado", redolente sugere também "que ressente a dor", "que expressa, de novo, a dor", "lamentoso uma vez mais, ainda" - com efeito, o poema caracteriza,

\footnotetext{
${ }^{124}$ Van der Leeuw, G. La religion dans son essence et ses manifestations, op. cit., p. 197.

${ }^{125}$ Andrade, Mário de. "Epitalâmio", in Há uma gota de sangue em cada poema, op. cit., p. 21.
} 
repetidamente, o passeio dos amantes pelo parque como o eterno retorno de um suplício: "é sempre assim", "já maquinalmente”, "pela décima vez conta e reconta/ como o prenderam e feriram”. Apesar disso, ao voltar do passeio, os amantes esplendem de esperança, sob o influxo da manhã balsâmica - a exalação de perfumes, como a música, é a sublimação do martírio. Nessa linha, quando o agônico soldado alemão de "Espasmo" estira os braços - formando-se a imagem de uma crucifixão? -, a manhã renasce em cantos e aromas: "Estira os braços... Os odores,/ em revoada puríssima e louçã,/ sobem, cantantes, multicores,/ cheios da força nova da manhã..."126. Da mesma forma que a música em Há uma gota de sangue, os perfumes ascendem ao céu, como o fumo dos sacrifícios, em oferenda a deus; eles realizam a passagem do material para o imaterial, assim como a música, de acordo com a Estética hegeliana ${ }^{127}$.

Em todos os seus níveis, Há uma gota opera passagens entre o mesmo e o outro - entre morte e vida, Novo Mundo e Velho Mundo, natureza e civilização, outono e primavera, abril e meio, autor e eu-lírico, eu-lírico e linguagem, profano e sagrado, homem e deus, entre outras -, o que José Antonio Pasta Júnior tem mostrado ser uma estrutura comum aos romances centrais da literatura brasileira, que procuram dar forma a uma matéria histórica cujo sentido profundo se encontra na passagem do moderno no arcaico, do local no universal, do nacional no europeu, e vice-versa ${ }^{128}$. Essas passagens, enfatiza o crítico, uma vez que se realizam por meio da supressão de mediações - ou por meio de mediações que se põem como imediatidade -, não constituem propriamente operações dialéticas, que se resolvessem em sínteses superiores - a mediação permitiria que o moderno superasse o arcaico, que a formação nacional superasse a influência européia etc.; ao contrário, essas passagens são a forma de um movimento ruinoso, isto é, que resulta na morte, na volta do atraso, no reforço da dependência em relação ao

\footnotetext{
${ }^{126}$ Idem. "Espasmo", in op. cit., p. 27.

${ }^{127}$ Hegel, G. W. F. Curso de Estética: o Sistema das Artes, São Paulo: Martins Fontes, 1996, pp. 287-358.

128 Pasta Júnior, José Antonio. "Tristes estrelas da Ursa - Macunaíma”, in op.cit., pp. 27-32; Idem. "O romance do Rosa - temas do Grande Sertão e do Brasil", in op.cit., pp. 61-70; Idem. "Volubilidade e idéia fixa (o outro no romance brasileiro)", in Sinal de menos, n4, São Paulo, 2010, pp. 13-25; Idem. "Le point de vue de la mort (une structure récurrente de la culture brésilienne)", in op. cit., pp. 157-168.
} 
estrangeiro e assim por diante ${ }^{129}$. Como se verá, as passagens encontradas em Há uma gota de sangue, realizadas por meio do sacrifício, produzem também, ao final da obra, embora quase todos os poemas do livro apresentem imagens da renovação da vida, uma espécie de má infinidade em que a própria vegetação renascida, tendo sido fertilizada com sangue, constitui um veneno mortífero.

Segundo tradições gregas e cristãs, os perfumes realizam o trânsito entre a matéria e o espírito, entre a terra e o céu, entre o homem e os deuses; nesses casos, a reflexão sobre as substâncias aromáticas relaciona-se à reflexão sobre as mediações entre o humano e o divino, de modo que "o perfume é sempre associado à abolição da fronteira, ao feliz encontro entre o aqui e o além"130. Nos poemas de Há uma gota de sangue, com efeito, a ascensão dos aromas naturais participa de um contexto - católico - de reconciliação com deus, ou melhor, do contexto de uma Nova Aliança que se estabelece entre a humanidade e seu deus, por meio do sacrifício pacificador do eulírico. A renovação da natureza, de que os perfumes e os cânticos figuram, no livro, como as expressões mais sublimes, constitui por sua vez a expressão suprema de uma renovação do sentimento religioso: “Ter razão é levar pelo atalho da fé. É as greis humanas, pela primavera,/ quando a terra toda é/ florida como uma quimera,/ conduzir para a luz, para a alegria", dizem os versos da "Exaltação da paz", opondo-se à irracionalidade da guerra ${ }^{131}$. A paz, de fato, que se encontra no horizonte de Há uma gota, confunde-se no livro com uma espécie de reconversão da humanidade ao catolicismo.

Com efeito, vimos que a obra se abre, no "Prefácio", com o pedido de perdão do eu-lírico em nome dos homens, dirigido, ao que tudo indica, à divindade católica. À vista disso, dissemos que o poema se organiza, em alguma medida, como uma oração; em verdade, porém, seu registro se situa entre a oração religiosa - que recorre a uma

\footnotetext{
129 Ver também Arantes, Paulo Eduardo. Sentimento da dialética na experiência intelectual brasileira: dialética e dualidade segundo Antonio Candido e Roberto Schwarz, São Paulo: Paz e Terra, 1992.

130 Albert, Jean-Pierre. Le sang et le Ciel: les saintes mystiques dans le monde chrétien, op. cit., p. 185. Ver Detienne, Marcel. Les jardins d'Adonis: la mythologie des aromates en Grèce, Paris: Gallimard, 1972.

${ }^{131}$ Andrade, Mário de. "Epitalâmio”, in Há uma gota de sangue em cada poema, op. cit., p. 17.
} 
força exterior para obter os fins desejados - e o da encantação mágica - que é eficaz por si mesma -, ambigüidade que se prende à convergência, no núcleo de Há uma gota de sangue, de cristianismo e cultos primitivos de vegetação ${ }^{132}$. Para Frazer, aliás, Cristo é uma figuração de um mito vegetal ${ }^{133}$. No "Prefácio", a feição mágico-religiosa do poema se revela de forma mais nítida na última estrofe, de modo que o caráter ritual da composição, instaurado no pedido de perdão inicial, confirma-se nesses versos finais, que se deve estudar melhor:
“deixai, floresçam, nos seus tons diversos, as rosas matutinas desta flora, a primavera destes simples versos!"”

Como ao pedir perdão, no início do poema, o eu-lírico volta a dirigir-se a uma instância divina, superior, agora a um "vós" típico das práticas litúrgicas, do discurso bíblico e das orações católicas. Assim, um dos esquemas principais das preces - o pedido de perdão seguido da solicitação de um benefício - estrutura o poema de Mário, poema que procura exercer sua influência mágica sobre o livro que ele introduz e, portanto, sobre a realidade mesma. De fato, Há uma gota se distingue da maioria da "escrita mágica" européia, na qual, apesar da assimilação profunda de aspectos encantatórios, "falta evidentemente a intenção, ou antes a confiança, a fé ingênua na eficácia das suas próprias palavras; esse distanciamento [...] modaliza a encantação, tornando-a um simples desejo: distância que é a mesma que separa o texto literário do texto mágico stricto sensu"134. A obra de Mário, por sua vez, procura desdobrar-se no mundo exterior, isto é, forçar a barreira, que constitui a literatura, entre o simbólico e a realidade, de modo que a enunciação da linguagem modifique, de maneira imediata, por seus próprios poderes, os fatos reais; noutros termos, Há uma gota procura nada mais,

\footnotetext{
132 Entre os ritos religiosos e os mágicos, diz Mauss, há “todas as espécies de graus” intermediários. Mauss, Marcel. “A prece”, in Ensaios de sociologia, op. cit., pp. 264-273.

133 Fazer, James George. Le Rameau d'Or, op. cit..

134 Vadé, Yves. L'enchantement littéraire: écriture et magie de Chateaubriand à Rimbaud, Paris: Gallimard, 1990, p. 116.
} 
nada menos, do que intervir na História por meio da força mágica da palavra, ou seja, suprimindo as distâncias, essenciais mesmo na literatura engajada, entre signo e coisa as marcas de sangue que ilustram as páginas da primeira edição do livro assinalam, como vimos, esse esforço da obra de ir além do plano da mera representação.

O impulso mágico de Há uma gota de sangue formula-se na última estrofe do "Prefácio" do livro. Depois de dirigir-se a um "vós" oculto, o eu-lírico enuncia uma espécie de encantação, destinada a garantir que os versos produzam os efeitos desejados sobre a matéria histórica. Como efeito, o modo como a palavra "floresçam" é utilizada no primeiro verso dessa estrofe confere ao verbo uma ambigüidade morfológica característica, segundo Jakobson, da "função mágica" da linguagem. De acordo com o filólogo russo, a "função mágica ou encantatória pode ser compreendida como a conversão de uma 'terceira pessoa' ausente ou inanimada em destinatária de uma mensagem conativa" - esta, como se sabe, é a mensagem orientada para o destinatário, ou seja, que procura influenciá-lo por meio de uma ordem, uma sugestão ou um apelo, de modo que a "função conativa encontra a sua expressão gramatical mais pura no vocativo e no imperativo"135. Assim, em sua função mágica, a mensagem transmite um apelo ou uma ordem, mas dirigidos a um terceiro ausente ou inanimado, de forma indireta - "Possa o sol parar!" - ou direta - "Sol, pára!". No verso de Mário, em princípio, "floresçam" é a forma subjuntiva do verbo, por meio da qual o eu-lírico de refere, em seu apelo à divindade, a terceiros - as rosas e os versos - expressando o desejo de que estes floresçam - no núcleo da magia, vale lembrar, está o desejo; além disso, contudo, a supressão da conjunção "que" - dada a necessidade de preservar a métrica decassilábica -, e a colocação do verbo entre vírgulas - "deixai, floresçam, nos seus tons diversos" -, faz com que o verbo pareça estar, também, no modo imperativo, na terceira pessoa do plural. Como vimos, esse tipo especial de ordem em terceira pessoa é uma das formas que assume a linguagem quando exercida em sua função mágica. A última estrofe do "Prefácio", portanto, enuncia ao mesmo tempo um apelo a

\footnotetext{
135 Jakobson, Roman. "Linguistique et poétique", in Essais de lingustique générale - 1. Les fondations du langage, Paris: Minuit, 1991, p. 216.
} 
uma divindade, não mencionada, e uma ordem direta à natureza, combinando, desse modo, duas formas tradicionais do discurso mágico-religioso.

Vale examinar o teor desse "imperativo encantatório", na expressão de Yves Vadé136, com que o "Prefácio" termina. O eu-lírico solicita, ou ordena, que os versos de Há uma gota "floresçam", o que significa, no contexto das imagens que compõem o "Prefácio", que esses versos exerçam sua influência benéfica - mágica - sobre a Europa em ruínas; os poemas são a primavera do Velho Mundo desvastado, a primavera que o rito praticado em Há uma gota de sangue visa a propiciar. A última estrofe do "Prefácio" constitui, portanto, uma espécie de fórmula mágica por meio da qual se procura garantir o êxito do ritual a ser celebrado no livro. Nesse quadro, os poemas têm a função de ajustar a história aos ciclos naturais, de fazer com que a primavera dos versos, gerada pelo sacrifício do eu-lírico, promova a primavera dos povos. Estabelecida no início do poema, a correspondência entre história e natureza se renova, agora com sinal invertido: assim como a guerra se reflete na catástrofe natural - o raio que faz tombar o guarantã -, o princípio do renascimento da vegetação, que os versos de $H a ́$ uma gota carregam por terem sido escritos com o sangue fecundo do eu-lírico imolado, deve refletir-se na sociedade e dar fim às "hecatombes mostruosas".

Essa eficácia imediata do discurso na realidade é própria das fórmulas mágicas, que realizam o desejo por meio de sua enunciação mesma, isto é, por uma virtude inerente à linguagem; na magia, o abismo entre dizer e fazer é suprimido. Não por acaso, a magia tem como principal aliada a música ${ }^{137}$, cujos efeitos físicos - como as “dinamogenias”, que Mário de Andrade tanto valorizava - são bem conhecidos: “a modulação musical é um ato que pretende influenciar um ser", escreve Jankélévich, recordando Orfeu, Dioniso e Platão ${ }^{138}$. Mário afirmou a relação profunda que existe entre a magia e a música de maneira categórica: “a música é uma parceira instintiva,

\footnotetext{
136 Vadé, Yves. L'enchantement littéraire, op. cit., p. 349.

137 Combarieu, Jules. La musique et la magie, Genebra: Minkoff, 1978. As idéias de Combarieu são mencionadas por Mário de Andrade logo na abertura de sua "conferência literária" sobre "Música de feitiçaria no Brasil”. Andrade, Mário de. Música de feitiçaria no Brasil, Belo Horizonte/Brasília: Itatiaia/ Instituto Nacional do Livro, 1983, p. 23.
}

138 Jankélévitch, Vladimir. La Musique et l'Ineffable, Paris: Seuil, 2002, p. 8. 
imediata e necessária, tanto das práticas da alta magia das civilizações espirituais, como da baixa magia das civilizações naturais" ${ }^{\prime 139}$. Assim, às formas mágicas que a linguagem do "Prefácio" assume vem unir-se a musicalidade dos versos do poema, os quais formam, nesse plano, uma rede complexa de associações sonoras variadas. Mário, com efeito, era um especialista em compor poemas como se fossem partituras musicais, atravessadas por um conjunto de relações melódicas, harmônicas e contrapontísticas muitas vezes imperceptíveis à primeira leitura. Não por acaso, o poeta elaboraria, poucos anos depois da publicação de Há uma gota de sangue, na obra que inaugura o modernismo literário brasileiro, uma poética baseada na música, ou seja, em que os conceitos musicais de melodia, harmonia e polifonia figuram como o paradigma da nova poesia lírica ${ }^{140}$. No "Prefácio" de Há uma gota, podem-se identificar inúmeras séries de sonoridades semelhantes ou aproximadas, que se cruzam formando uma densa trama de rimas externas e internas, de assonâncias e aliterações, uma verdadeira “orquestração da linguagem”, que não cabe expor à exaustão aqui, mas de que se deve notar em alguma medida, de modo a demonstrar o caráter profundamente musical desse soneto. Vale transcrever, uma vez mais, o poema:

$$
\begin{aligned}
& \text { “Perdão. - Também, no mato, se depara } \\
& \text { guarantã que tombou, no último esmaio, } \\
& \text { porque, vencido à chuva, o estraçalhara } \\
& \text { - Pollice verso! - o gládio irial do raio... }
\end{aligned}
$$

Tombou entre os cipós. E, quando maio sobre o exício medonho se escancara, vê que o recobre o riso novo e gaio das trepadeiras e da manhã clara.

\footnotetext{
139 Andrade, Mário de. Música de feitiçaria no Brasil, op. cit., p. 23.

140 Andrade, Mário de. "Prefácio Interessantíssimo", in Paulicéia desvairada, in Poesias completas (ed. crítica de Diléa Zanotto Manfio), Belo Horizonte/Rio de Janeiro: Villa Rica, 1993, pp. 59-77.
} 
- Por sobre o torso lívido e canhestro

da Europa em ruína vem também agora

brilhar, de manso, o maio em sol dum estro:

deixai, floresçam, nos seus tons diversos, as rosas matutinas desta flora, a primavera destes simples versos!"

O leitor terá notado que, além das rimas tradicionais de um soneto, as sílabas tônicas dos versos - os quais são, na maior parte, decassílabos heróicos - constituem séries de ressonâncias que organizam a estrutura sonora do poema. Essas séries integram, também, sílabas átonas dos versos, de modo que as "linhas de força" do campo musical do poema ressoam no "segundo plano sonoro" da composição:

[ã] perdão - guarantã - quando - manhã - manso

[aio] gládio - esmaio - raio - maio - gaio - maio - deixai

[ó] cipós - recobre - Europa - sol - rosas - flora

[ô] tombou - tombou - sobre - novo - torso - ([0̃] medonho - tons $)$

[í] vencido - exício - riso - lívido - ruína - matutinas - simples

[é] verso - diversos - primavera - versos

[es] canhestro - estro - floresçam - (esmaio - estraçalhara - exício - escancara)

O poema está coalhado, portanto, de "correspondências sonoras". Assim, os dois últimos versos do poema contêm um par de rimas internas que tornam especialmente musical a conclusão "mágica” do soneto: “as rósas matutinas desta flóra,/ a primavéra destes simples vérsos!". O primeiro desses versos, vale notar, reitera a sonoridade, com leve diferença na acentuação, do segundo verso do primeiro terceto: “da Európa em ruína vem também agóra// as rósas matutínas desta flóra”. Por sua vez, a rima em -óra desses tercetos é uma espécie de modulação da rima em -ára das quadras, e se modula 
afinal para -éra no interior do último verso. Para encerrar essa breve análise, note-se que Mário esboça empregar, no "Prefácio", as seqüências de assonâncias e aliterações, que ele exploraria, como técnica modernista, ao longo dos anos 1920. Nos dois primeiros versos do poema, por exemplo, ressaltam-se a série de "t" ("também-mato-guarantãtombou"), a série de “m” ("também-mato-guarantam-tombou-último-esmaio"141, que se desdobra na repetição em espelho de "também-tombou-tombou-também”), e a série de "a" ("mato-depara-esmaio"). Note-se, além disso, que em "guarantã" ressoa "ara", de "depara", ao passo que "depara" é uma espécie de inversão de "perdão", enquanto "perdão" rima com "guarantã". Ainda no campo das aliterações, deve-se registrar, nas duas quadras, a seqüência de versos iniciados com "p" átono ("perdão-porque-pollicepor sobre") e que integra uma série maior de oclusivas em sílabas tônicas, formada por “perdão-também-depara-tombou-tombou-cipó-medonho".

O emprego das aliterações e das assonâncias se radicaliza em uma estrofe do poema seguinte ao "Prefácio", a condoreira "Exaltação da paz", poema que "oficialmente" inicia o rito da obra, como se verá adiante. Depois de invocar a paz e de relembrar, por meio da descrição de uma paisagem bucólica e com versos canoros, impregnados de sonoridades suaves, os tempos de harmonia social e natural anteriores à guerra, o poema explode em articulações violentas, antecipando a dicção de Paulicéia desvairada:

"O Sol, nas arraiadas calmas,

brilhara sobre montes, sobre vale,

sobre inconscientes campônios,

sobre paisagens de Corot;

havia beijos mornos de favônios,

a aos altos montes e fundos vales

os galhos eram compassivas almas,

dando sombras no prado e frescura nas fontes...

141 A grafia original de guarantã, isto é, guarantam, foi atualizada somente nas edições recentes da Obra imatura. 
- Hoje, por vales e por montes,

tudo mudou.

Tudo mudou!... Atra estralada de bombardas

em sanha, um clangorar de márcios trons reboando,

tempestades terrestres estrondeando,

tiritir, sibilar, zinir miúdo de balas

caindo sobre absconsas valas,

coriscos, raios levantando-se de covas,

batalhões infernais em soturnas atiardas,

clarins gritando, baionetas cintilando,

bramidos, golpes, ais, suspiros, estertores..." 142

Assim como a exploração da sonoridade das palavras, também o caráter mágico da poesia se acentua e evidencia na "Exaltação da paz", em comparação com o "Prefácio", onde a música e a religião são elementos mais implícitos. A abertura da "Exaltação", por sua vez, é ostensivamente calcada no modelo da invocação. Nela o leitor encontra, em nítida configuração mágico-religiosa, uma abundância de vocativos e imperativos própria da prece e da função mágica da linguagem, como vimos com Jakobson:

"Ó paz, divina geratriz do riso,

chegai! Ó doce paz, ó meiga paz,

sócia eterna de todos os progressos,

estendei vosso manto puro e liso

por sobre a Terra, que se esfaz!

Ó suave paz, gandiosa e linda,

${ }^{142}$ Andrade, Mário de. "Exaltação da paz”, in Há uma gota de sangue em cada poema, in op. cit., p. 16. 
chegai! Ponde por sobre os trágicos sucessos,

dos infelizes que se degladiam,

vossa varinha de condão!

Tudo se apague! este ódio, esta cólera infinda!

Fujam os ventos maus, que ora esfuziam,

que se vos ouça a voz, não o canhão!

Ó suave paz, ó meiga paz!...”

Ao contrário do "Prefácio", a "Exaltação" nomeia a entidade sobrenatural à qual seus versos se dirigem, o que confere ao poema uma natureza religiosa evidente - e o torna, vale notar, mais próximo da prece, que recorre a deuses, do que da encantação, que age por si mesma, não obstante a linguagem assuma feição propriamente mágica em dois versos da segunda estofe, nos quais o sujeito elocutório exclama como um feiticeiro: "Tudo se apague! este ódio, esta cólera infinda!/ Fujam os ventos maus, que ora esfuziam". Nesse contexto, o eu-lírico figura como uma espécie de sacerdote a celebrar o intróito de uma liturgia.

A liturgia de Há uma gota, como temos visto, é de fundo católico, embora incorpore noções dos ritos primitivos de vegetação; ela tem em seu centro, portanto, a reprodução do sacrifício de Cristo. Não por acaso, ela se abre com uma "exaltação", termo que remete a uma conhecida festa do calendário litúrgico cristão, a Exaltatio Sanctae Crucis ["Exaltação da Santa Cruz"], que comemora a apresentação da "verdadeira cruz" aos fiéis durante a consagração da Igreja do Santo Sepulcro, no ano de 335. Assim como a Sexta-Feira da Paixão, a Exaltação concentra-se no simbologia da cruz de Cristo, mas em sentido inverso, de modo que as duas datas formam uma espécie de contraponto: na primeira, a cruz figura como instrumento de sofrimento e morte; na segunda, a cruz é celebrada como meio de salvação, de dissipação das trevas e de vitória sobre o pecado - a "cruz vivificante", como se diz em algumas tradições da festa. Ora, como temos visto, a idéia cristã do sacrifício redentor, que faz voltar a luz e renascer a vida, é o núcleo mesmo de Há uma gota de sangue, cujos poemas retratam, 
ao lado das cenas terríveis da guerra, a imagem da natureza renascida em exaltação literalmente, inclusive, sob a forma de cânticos e perfumes que se elevam aos céus.

“Exaltação da paz” dá início ao ritual de Há uma gota de sangue, portanto, sob o signo da cruz redentora. Não à toa, surge nesse poema de abertura uma figura sacrificial importante da obra, composta pelas imagens do pão (ou do trigo), do livro e do sangue. Assim, em oposição à desrazão da guerra, afirma o eu-lírico, em um trecho em que ecoa Castro Alves:

"Muito mais ter razão é conduzir as gentes

pelo caminho bom das alegrias:

$[\ldots]$

distribuir pelos povos

trigos e livros a mancheias;

$[\ldots]$

...Derramar a verdade em cada casa;

dar-lhe um livro, que é força [...];"

O sangue, sugerido pelo verbo "derramar", associa-se de forma explícita a essa figura nitidamente eucarística apenas no último poema do livro, "Os carnívoros", onde ele terá a função decisiva de reverter o sentido da imagem, que ao longo de Há uma gota é sempre positivo. Com efeito, antes do poema final, o trigo e o livro figuram como os alimentos do corpo e da alma; eles compõem, desse modo, o conjunto de motivos, como a música e os aromas, como as flores e os pássaros, que representam os tempos de paz, em oposição aos tempos estéreis da guerra - um contraste que estrutura, sempre de maneira bastante retórica, em grandioso chiaroscuro, quase todos os poemas de Há uma gota. Mas além de participarem do mesmo complexo de imagens, o livro e o trigo se identificam em Há uma gota de sangue. No poema "Devastação", ao evocar, em tom bucólico, as épocas passadas de harmonia, anteriores ao nascimento do "orgulho" que levou os homens à guerra, o eu-lírico descreve uma paisagem dominada pela 
"poesia alourada dos trigais" - o trigo é poesia. Por sua vez, como se verá, a poesia, que é sangue em Há uma gota, é também trigo, "pão" da alma - ou seja, conforme se revela em "Os carnívoros", a poesia é a hóstia, o próprio corpo de Cristo, que é a encarnação do Verbo, a união de pão e palavra, segundo a doutrina cristã, em que a obra encontra-se profundamente arraigada. Ora, assim como a associação entre poesia e sangue, também a associação entre poesia e trigo (pão) tende a ultrapassar os limites da metáfora, de modo a suprimir a distância entre a mimesis e a realidade: a poesia de Há uma gota não quer apenas representar o pão eucarístico; ela quer ser o pão eucarístico, realizando para isso um movimento de abolição da distância entre o simbólico e o real. Esse movimento se realiza, sob o influxo do sangue, em "Os carnívoros", onde ele se desdobra na supressão ritual da distância entre a obra e o leitor. Desse modo, "Os carnívoros é uma espécie de consumação negativa da associação, de conotação eucarística, formada na "Exaltação da paz", entre livro e trigo; em verdade, conforme veremos adiante, o último poema de Há uma gota consuma em todos os sentidos a prece feita no primeiro.

“Exaltação da paz” se encerra com uma invocação mágico-religiosa semelhante à proferida no início do poema, seguida de uma previsão dos futuros tempos pacíficos:

"Ó doce paz, ó meiga paz!...

Vinde divina geratriz do riso;

estendei vosso manto puro e liso

por sobre a Terra que se esfaz!

E novamente os povos sossegados, mais felizes alfim, menos incréus, envolvereis, ó paz imensa!

- De novo os cantos rolarão nos prados;

e os homens todos rezarão aos céus, numa ressurreição da esperança e da crença!" 
Feita a oração inicial, o rito de Há uma gota de sangue começa apresentando um quadro da paisagem invernal e crepuscular da Europa durante a guerra. Tudo está morto, e o solo coberto de neve é a sepultura de mármore, a sepultura "profana, sem unção", onde jazem as flores, os pássaros etc.: “Qual um mármore plano de moimento,/ silenciou o caminho. É a sepultura,/ profana, sem unção,/ onde, com a última violeta,/ jaz a franca alegria do verão.../ [...] Ninguém. Os derradeiros pios/ voaram de manhãzinha; mas em breve sepultaram-se sob a neve,/ mudos e frios. Tudo alvo... apenas a tristeza preta,/ e o vento com seus roncos...". Ao final, um sinal de vida, que é todavia, ironicamente, um sinal de morte - note-se que os versos recebem um tratamento quase modernista para representar a surpresa, prefigurando Paulicéia desvairada: "Ninguém./ Alguém!/ Olha, junto dos troncos,/ um reflexo de baioneta!"143. Seguem-se, então, quatro cenas - "Epitalâmio", "Refrão de obus", "Primavera" e "Espasmo" - nas quais são explorados os contrastes entre a guerra e a natureza que começa a renascer. Assim, o passeio de um alemão ferido com sua amada francesa pelos jardins de um hospital, a trajetória de uma bomba no ar, as ruínas de um canhão e a agonia de um soldado no campo se opõem ao advento da manhã e da primavera. São poemas "épicos", por assim dizer, que narram cenas particulares de guerra, em que não há qualquer referência ao eu-lírico, cuja presença é marcante, contudo, na vibração romântica, à maneira de Victor Hugo, dos versos. Combinam-se nesses poemas, portanto, a objetividade narrativa e certo subjetivismo lírico exacerbado, como se os outros - o soldado, a bomba, o canhão, a natureza - se tornassem protagonistas dos versos não em virtude de um recuo do eu-lírico, mas justamente por meio da potenciação de um eu-lírico que, expandindo-se de forma desmedida, converte-se em todos os outros - assim como a vítima sacrificial se torna o duplo de toda a sociedade e é destruída somente quando se encontra carregada, ao máximo, de sagrado.

Contudo, nos últimos poemas de Há uma gota de sangue, mais precisamente a partir de "Espasmo", a imagem da renovação da natureza desaparece - exceto no poema

\footnotetext{
${ }^{143}$ Andrade, Mário de. "Inverno", in Há uma gota de sangue em cada poema, in op. cit., pp. 19-20.
} 
final do livro, onde ela ocupa um lugar central, mas para ser negada ad infinitum. Em seu conjunto, portanto, a obra realiza um movimento decepcionante: dado o esquema simbólico que está na base de Há uma gota, a passagem de "Inverno", no começo do livro, para "Primavera", seu poema central, faria supor uma passagem correspondente da guerra à paz, mas isso não ocorre. Ao contrário, a partir de "Primavera", os poemas se tornam mais negativos, sem a figuração da esperança que se encontra no final da "Exaltação da paz" e de "Epitalâmio", por exemplo, ou a imagem da vitória da natureza sobre a barbárie dos combates, encontrável em "Primavera". Por sua vez, "Guilherme", "Devastação", "Natal” e "Lovaina" são poemas "em tom menor", nos quais a redenção não se encontra à vista. $\mathrm{O}$ ataque ao Kaiser alemão que constitui "Guilherme" termina com sinal de menos: "Infeliz! Pensa em luz, e engendra escuridades;/ quer plantar o bem, o mal deita raízes!.../ - Certo: é a maior das infelicidades/ fazer dos outros homens infelizes"144. Por sua vez, os versos finais de "Devastação" descrevem uma estátua gélida, alegoria da dor do eu-lírico a contemplar a Europa devastada; a esperança, que brilha nos primeiros poemas do livro, agora é incerta e menor que a descrença: "A esperança talvez lhe santifica e unge/ o olhar, mas o sorriso, o sorriso que a mina,/ trai o penoso fel duma desilusão"145.

Em "Natal", volta no livro o inverno, sem que a paz tenha sido selada; a visão fantasmagórica da cidade de Reims forma uma espécie de pendant com a paisagem desoladora do campo representada em "Inverno", no começo da obra - figurando-se desse modo, em Há uma gota, algo como o eterno retorno do mesmo: “A neve, sempre a mesma,/ cai, continua de cair; e o vento/ - Bruscas rajadas brancas - se desfralda,/ como túnica de avantesma". A expressão mais eloqüente desse quadro sinistro, no poema, é a ausência de qualquer comemoração do nascimento de Cristo na cidade; em guerra, os homens continuam distantes da divindade, o que se exprime por meio do silêncio tenebroso que domina a paisagem - a música, lembre-se, funciona em Há uma gota como forma e expressão da união com o deus: “- Em Reims, os sinos não badalam

\footnotetext{
${ }^{144}$ Idem. "Guilherme", in op. cit., p. 30.

145 Idem. "Devastação", in op. cit., p. 34.
} 
mais!/ [...] Natal... Mas não há luzes nas capelas!.../ [...] No colo virgem de Maria,/ junto dos anjos tutelares,/ rindo, estendendo os bracinhos nus,/ nem se lembraram quem se lembraria! - nem se lembraram de repor Jesus!...// - Em Reims, os sinos não badalam mais!/ [...] - Friorenta,/ a grande catedral emudeceu:/ e para ela a alegria dos natais,/ toda a alegria dos natais morreu!...// - Em Reims, os sinos não badalam mais!..."146. O poema registra o vazio, a falta, e seus versos assumem a forma da negação: os sinos não badalam, não há luzes, a estátua de Cristo não foi reposta nos braços da Virgem etc. Por fim, "Lovaina" descreve a destruição da cidade belga, e termina com a imagem da destruição e do incêndio da universidade: "só, dentre as ruínas da universidade/ eu vi os grandes livros fumegando!"'147.

Em suas primeiras estrofes, "Os carnívoros", poema seguinte a "Lovaina", parece reverter o sentido negativo deste e dissipar a tonalidade sombria dos poemas anteriores, uma vez que projeta a imagem dos tempos de paz na Europa após o fim da guerra. Valendo-se de motivos campestres utilizados nos poemas iniciais do livro cânticos, pássaros, manhã clara, vegetação renascida - "Os carnívoros" representa a nova colheita do trigo, evocando "As respigadeiras", pintura de Millet, onde o trabalho no campo também assume, como em Há uma gota de sangue, certa aura religiosa:

\footnotetext{
"Quando a paz vier de novo, nova e franca, passar nestas estradas e caminhos, novas aves talvez e novos ninhos hão-de agitar-se pela manhã branca... $[\ldots]$
}

Toda a população ir-sehá nos vales colher o trigo novo e lourejante; e, na pressa afanosa, bem distante

\footnotetext{
${ }^{146}$ Idem. "Natal", in op. cit., p. 35-36.

${ }^{147}$ Idem. "Lovaina", in op. cit., p. 38.
} 
lhe passará da idéia tanta luta, tantos passados males!

Pelo campo ceifado, à Ave Maria, na tarde enxuta

e fria, enquanto o vento remurmura, meigo e brando, mulheres de Millet, robustas e curvadas, irão glanando, irão glanando...

Tudo será colheita e riso. - Então, depois de tantas fomes e misérias, de tantas alegrias apagadas, de tantas raivas deletérias, os celeiros de novo se encherão."

Parece consumar-se, enfim, a "ressurreição" prevista na "Exaltação da paz". Todavia, um veneno mortal subjaz à bonança aparente: o solo onde cresce o trigo fertilizou-se com o sangue dos soldados mortos em combate, o sangue impuro, derramado fora do sacrifício ritual, o sangue da violência sem controle, cuja presença denuncia o assassinato e prenuncia novas catástrofes. Assim como a violência que lhe deu origem, esse sangue "começa a correr e não pode mais ser detido, insinuando-se por toda parte", ao contrário do sangue sacrificial, cujos efeitos são dirigidos e limitados pelo rito; além disso, produzido pelo crime, o sangue "conspurca tudo o que toca com as cores da violência e da morte"148. Nessa linha, em "Os carnívoros", o sangue dos soldados se espalha pelos campos e se torna a seiva do novo trigo, envenenando-o. Por isso, com sarcasmo, exclama o eu-lírico, na seqüência dos versos acima citados:

148 Girard, Réné. A violência e o sagrado, op. cit., p. 49. 
"Mas o trigo abastoso dos celeiros

relembrará o sangue, a vida,

os penosos momentos derradeiros

duma geração toda destruída...

Olhai! Hoje o trigal é mais verde e mais forte!

O chão foi adubado a carne e sangue...

Que importa haja caído um exército exangue,

se deu a vida ao trigo tanta morte!

Este é o trigo que é pão e alento!

Vós que matastes com luxúria e sanha,

vinde buscar o prêmio: é o alimento...

Ei-lo: em raudal, em nuvem, em montanha!

Este é o trigo que nutre e revigora!

É para todos! Basta abrir as mãos!

Vinde buscá-lo!... - Vamos ver agora,

Quem comerá a carne dos irmãos!”

"Hoje o trigal é mais verde", declara o eu-lírico. Como se sabe, o joio, que costuma crescer nas mesmas áreas produtoras de trigo, e que é tão semelhante ao trigo na aparência, diferencia-se dele, quando cresce, porque permanece verde, ao passo que o trigo muda de cor, assumindo um tom amarelado, cor de palha. Assim, em "Os carnívoros", ao dizer que o novo trigo, o trigo do pós-guerra, no momento da colheita, é "mais verde", o eu-lírico parece indicar que o trigo que nasce adubado pelo sangue da guerra é o "falso trigo", o outro negativo do trigo, isto é, o joio, a erva daninha, venenosa, dos trigais. Mário de Andrade, conforme dito, era católico praticante quando compôs os poemas de Há uma gota de sangue; em 1916, por exemplo, pouco antes de 
escrever o livro, aplicara-se em traduzir, do latim, o Thesourinho espiritual da Congregação Mariana de Sta. Efigênia, sendo que ele mesmo era congregado ${ }^{149}$; não lhe terá escapado, portanto, ao compor os versos de "Os carnívoros", a simbologia que o Cristo, segundo o evangelho de Mateus, atribuiu ao joio e ao trigo, em uma conhecida parábola. Nesta, o campo é o mundo, o trigo são os filhos de deus, o joio são os filhos do diabo, e a colheita é o juízo final ${ }^{150}$; o semeador do trigo é o próprio Cristo, que semeia com as palavras, as quais são "a semente" - Semen est Verbum dei ${ }^{151}$. Nesse contexto simbólico, o joio é o alimento maligno, o avesso do trigo, que simboliza o pão da vida, enquanto o joio representa o pão da morte, que figura, em "Os carnívoros", como um pão de sangue, de sangue impuro, venenoso.

O poema não descreve esse trigo letal de forma distanciada; ao contrário, ele o oferece ao leitor. Noutras palavras, os versos convidam o leitor a buscar o alimento mortífero. Confundem-se, nesse ato, a instância dos camponeses europeus e a dos leitores de Há uma gota de sangue, pois se identificam o trigo adubado com o sangue da guerra e os próprios versos do poema. À vista disso, e considerando-se a conotação eucarística que o trigo tem no catolicismo e, em especial, como temos visto, no livro de Mário, pode-se dizer que o eu-lírico assume, em "Os carnívoros”, a posição do sacerdote que convoca os fiéis para a consumação da eucaristia, mas de uma eucaristia inversa à do modelo católico, como notou a crítica ${ }^{152}$. No contexto cristão, a eucaristia tradicional, como se sabe, quer propiciar a salvação do homem, uma vez que consiste na repetição simbólica do sacrifício definitivo, ou seja, do sacrifício que pretende superar a lógica infernal da reprodução das imolações rituais - como se sabe, segundo a doutrina, o Cristo, ao derramar o próprio sangue, o sangue divino, e não o sangue alheio, aboliu o

\footnotetext{
${ }^{149}$ Lopez, Telê Porto Ancona. Mário de Andrade: ramais e caminho, op. cit., pp. 21-22.

${ }^{150}$ Mateus: 13:24-43, in Bíblia Sagrada, op. cit., p. 22.

${ }^{151}$ Lucas: 8:11, in Bíblia Sagrada, op. cit., p. 89.

152 Lopez, Telê Porto Ancona. Mário de Andrade: ramais e caminho, op. cit., p. 28. Em carta de 1942, Mário também atribui o sentido de uma eucaristia - desta vez positiva - a sua correspondência com os jovens: "Uma certa moralidade messiânica, muito minha mesmo, me permitia não me contar senão naquilo em que eu podia ser lição [...]. Espécie de sacrifício muito cristão, 'este é o meu corpo, este é o meu sangue, alimentai-vos', que, se não me engano, me fez muito bem”. Castro, Moacir Werneck de. Mário de Andrade: exílio no Rio, Rio de Janeiro: Rocco, 1989, p. 186.
} 
pecado de uma vez por todas, de modo que o sacrifício não precisa mais ser reiterado pelos homens. Ao contrário, a eucaristia celebrada em "Os carnívoros" consuma o sacrifício criminoso, que não supera o regime da violência, mas o repõe, de modo que a comunhão que o poema propõe é funesta; em vez de salvar o leitor - que ocupa, nesse esquema, a posição do sacrificante, do beneficiário do sacrifício -, a eucaristia de "Os carnívoros" causa, nele, a morte. Assim, enquanto o sacramento católico pretende reatualizar a redenção dos homens e a remissão dos pecados, o sacramento praticado no final de Há uma gota de sangue, em uma espécie de inversão demoníaca, prende a humanidade aos crimes por ela cometidos durante a guerra; noutros termos, ao passo que a eucaristia cristã redime a culpa, a eucaristia às avessas do poema de Mário condena à morte - com efeito, essas últimas estrofes de Há uma gota de sangue configuram-se como uma espécie de juízo final - na linha, aliás, da parábola bíblica do joio e do trigo -, de modo que há, nesses versos, a vibração de uma espécie de sacra fúria, que reaparece com freqüência na poesia posterior de Mário de Andrade.

O sentido de toda a obra, dessa forma, se inverte por completo nas últimas estrofes. Vimos que, desde o início, mais precisamente desde a capa do livro, Há uma gota de sangue se organiza como um rito sacrificial em que a poesia, por meio do sacrifício do eu-lírico, é escrita com o próprio sangue da vítima expiatória, o sangue fecundo, que renova a vida natural e, portanto, a vida social, segundo o esquema mágico-religioso dos ritos de vegetação que está na base do livro, esquema de acordo com o qual a dinâmica da sociedade corresponde aos ciclos da natureza. Para garantir que o sangue, substância ambivalente no contexto das religiões, produza os seus efeitos benéficos - e não, os letais -, sua efusão é preparada por meio de ritos preliminares e dosada com rigor - apenas uma gota em cada poema. Desse modo, a estrutura ritual disciplina o sacrifício, assegurando que as identificações envolvidas na operação sacrificial não ultrapassem os limites que preservam as distinções entre os participantes do rito, igualmente necessárias para que a imolação beneficie a sociedade e não a aniquile. Noutros termos, é preciso que a vítima, ao mesmo tempo, seja e não seja o sacrificante, que em Há uma gota de sangue é o leitor, que por sua vez representa a 
humanidade; o êxito do sacrifício depende de que o sacerdote, a vítima e o sacrificante sejam simultaneamente idênticos - para que a vítima funcione como um substituto do sacrificante - e distintos - para que o sacrificante não compartilhe a sorte da vítima. Essa coexistência difícil, perigosa mesmo, de identidade e alteridade se estabelece, em Há uma gota de sangue, nos ritos de limiar, que por um lado selam, de início, um pacto de sangue com o leitor, mas que por outro lado definem as posições dos que participam no sacrifício e expõem o método e a finalidade do ritual. Ao longo do livro, a distância entre a obra e o leitor se mantém, entre outras coisas, em virtude do caráter por assim dizer "épico" da maior parte dos poemas, que narram cenas da guerra. A ordenação rigorosa das composições, exposta acima, contribui para preservar essa distância, uma vez que "metodiza" a escrita e a leitura.

A renovação de natureza, que se inicia logo após "Inverno" e culmina, no meio do livro, em "Primavera", não propicia, entretanto, o advento da paz; a história não responde à força mágico-religiosa dos poemas. Conforme exposto anteriormente, os poemas tornam-se, a partir de então, negativos, desprovidos da esperança que ilumina os versos finais de algumas das composições da primeira metade da obra, como "Prefácio", "Exaltação da paz" e "Epitalâmio". Essa inflexão para o sombrio culmina na figuração do Natal fantasmagórico de Reims, portanto no retorno do inverno, e na representação da destruição da biblioteca de Lovaina. A imagem dos livros calcinados, fumegando, é bastante sugestiva, uma vez que Há uma gota deposita no livro, o "trigo da alma", a esperança de pacificar-se a Europa: queimados na fogueira profana produzida pelas bombas, os livros são sacrificados inutilmente, criminosamente - como as vítimas da guerra. Na destruição dos livros da biblioteca de Lovaina se reflete o fracasso do impulso pacifista, sacrificial, do próprio livro de Mário.

Não por acaso, no poema seguinte, "Os carnívoros", ao projetar-se a imagem bucólica dos futuros tempos de paz, a poesia se identifica ao sangue impuro dos que foram mortos na guerra; ela se torna o "joio da alma", o veneno do espírito. Assimila-se, portanto, ao sangue que se espalha sem controle, como a violência que o produz; sua efusão deixa de ser dosada, torna-se copiosa: "Ei-lo: em raudal, em nuvem, em 
montanha!”, exclama o eu-lírico, oferecendo ao leitor o trigo nutrido com o sangue dos crimes - o trigo, vimos, é também a própria poesia. Desse modo, o rito sacrificial "descarrila", abolindo-se em todos os níveis os limites, que as regras rituais preservavam em alguma medida, entre o mesmo e o outro: o sacrifício do eu-lírico não se diferencia mais do sacrifício dos soldados, e se desdobra, por sua vez, no sacrifício do leitor. Em suas últimas estrofes, Há uma gota de sangue lança-se ao leitor, suprimindo a distância que lhe permitia beneficiar-se do sacrifício. O leitor é convocado a compartilhar o destino da vítima sacrificial; o pacto de sangue, celebrado no início da obra, revela-se um pacto de suicídio. Com efeito, na antropofagia, a que o poema instiga o leitor, o devorador se torna o devorado e o devorado, o devorador: " $\mathrm{O}$ 'eu' se determina como 'outro' pelo ato mesmo de incorporar este outro, que por sua vez se torna um 'eu"'153. No horizonte funesto de Há uma gota de sangue em cada poema, a passagem da poesia no leitor e vice-versa é destruição mútua ${ }^{154}$.

Conforme demonstrou José Antonio Pasta Júnior, a passagem mutuamente supressiva da obra no leitor e do leitor na obra constitui uma das manifestações extremas, em literatura, da lógica da formação supressiva. Estudando O Ateneu, Pasta explica esse movimento paradoxal e destrutivo, que se expressa na conformação ritualística da obra literária: "O romance inteiro se dá como um vasto rito em câmara ardente, ofício/cerimônia no limiar do absoluto. Em casos assim, o leitor é sempre, de alguma forma, o 'senão do livro', como o declara, em sua chave de sátira e fastio, aquele outro narrador cioso de eternidade e absoluto, o finado Brás Cubas: 'porque o maior defeito deste livro és tu, leitor'. [...] O Ateneu, consoante a regra paradoxal que é a sua, forma o leitor pela sua supressão. A contradição posta por sua alteridade tão

\footnotetext{
153 Castro, Eduardo Viveiros de. "Xamanismo e sacrifício", in A inconstância da alma selvagem - $e$ outros ensaios de antropologia, São Paulo: CosacNaify, 2002, p. 462.

154 Essas passagens são próprias do sacrifício, que tem a função, justamente, de "fazer passar algo" do profano para o sagrado e vice-versa - daí o risco envolvido em todo sacrifício, uma vez que o sagrado e o profano constituem instâncias que não podem misturar-se sem precauções extremas, sob pena de produzir-se uma catástrofe; como se disse acima, a codificação a que o rito submete a operação sacrificial assegura que as transferências realizadas pelo sacrifício beneficiem os deuses e os homens. O mínimo deslize basta, contudo, para que as passagens provoquem a aniquilação do profano e a contaminação do sagrado, como em "Os carnívoros", onde o sangue impuro mistura-se ao sangue limpo e a comunhão com a obra é mortal para o leitor. Sobre o interdito da mistura do sagrado e do profano, ver Caillois, Roger. L'homme et le sacré, op. cit., pp. 23-45.
} 
indispensável quanto insofrível deverá resolver-se numa conciliação de natureza mágico-religiosa - pela sua participação no absoluto mediante a absorção ritual, operação que, sob certos aspectos, o constitui dissolvendo-o - pondo-o a oficiar suas próprias exéquias. Por isso, a refração do sagrado, nesse livro, longe de ser experiência de comunhão, acompanha-se de um traço de despotismo sinistro, que tem muito de terrorismo. Algo de uma propedêutica da morte ou pacto de suicídio se celebra aí"155.

As formas literárias, como se sabe, têm como substrato as formas sociais; em outras palavras, as estruturas literárias são, sobretudo, sínteses profundas, reduções estruturais das estruturas históricas, às quais elas dão forma artística ${ }^{156}$; essa "essência social" das formas literárias, disse Adorno, verifica-se mesmo na lírica, tida como a mais individual entre as formas de expressão literária, uma vez que o indivíduo, mesmo em seu isolamento na sociedade burguesa, é ele próprio socialmente mediado ${ }^{157}$. Com efeito, o regime da formação supressiva, observa Pasta, é uma forma social, que estrutura as relações interpessoais no Brasil, as quais se fundam na combinação contraditória de capitalismo e escravidão que modelou a sociedade brasileira, sem nunca ter sido inteiramente superada. Essa combinação, diz o crítico, produz a vigência de um regime de relação interpessoal contraditório, em que a autonomia do outro é ao mesmo tempo pressuposta e inconcebível, de modo que o sujeito vem a ser passando no outro, portanto suprimindo o outro; ao passar no outro, contudo, ao vir a ser sendo o outro, o sujeito vem a ser deixando de ser, ou seja, ele é suprimido pelo outro. Assim, a lógica da formação supressiva se encontra no coração das formas sociais brasileiras e implica sempre a supressão recíproca do mesmo e do outro ${ }^{158}$.

Como vimos com Pasta, nas obras em que a formação supressiva funciona como um princípio estrutural, esse regime se desdobra, em última análise, na relação da obra literária com o seu outro indefectível, o leitor. Em Há uma gota de sangue, esse

\footnotetext{
155 Pasta Júnior, José Antonio. Pompéia: a metafísica ruinosa d’O Ateneu, op. cit., pp. 8-9.

156 Adorno Theodor W. Teoria Estética, op. cit., 165-167, 247-277. Schwarz, Roberto. "Pressupostos, salvo engano, de 'Dialética da malandragem", São Paulo: Companhia das Letras, 1997, pp. 129-155.

${ }^{157}$ Adorno Theodor W. "Palestra sobre lírica e sociedade", in Notas deliteratura I, op. cit., pp. 65-89.

158 Conforme dito, a lógica da formação supressiva, bem como sua base histórico-social, serão estudadas com mais vagar, e em alguns de seus principais desdobramentos, na segunda parte deste trabalho.
} 
movimento se explicita nos versos finais de "Os carnívoros", que são os versos finais do próprio livro; todavia, ele se realiza em verdade desde o início da obra, uma vez que a formação supressiva comporta uma estrutura sacrificial e que o sacrifício, em seu núcleo, consiste em um modo de formação por meio da supressão - a vítima vem a ser deixando de ser, perdendo-se ao passar no absolutamente outro, ou seja, no sagrado; além disso, na operação sacrificial, o sacrificante e a vítima passam um no outro, destruindo-se mutuamente, embora o rito assegure que a destruição do sacrificante seja somente simbólica e se converta em benefício; todo sacrificante, em alguma medida, sacrifica a si mesmo por meio da vítima. Sendo assim, ainda que de forma oculta, a estrutura profunda de Há uma gota de sangue em cada poema reproduz uma estrutura histórica que está na base das relações intersubjetivas no Brasil. Com efeito, para que a vítima funcione como substituta, é preciso que se estabeleça entre ela e o sacrificante uma relação em que a alteridade seja ao mesmo tempo negada e afirmada, uma estrutura relacional semelhante à que Pasta identificou na sociedade brasileira.

Há uma gota de sangue em cada poema se encerra com a imagem de um um paraíso em que subjaz uma pena eterna, isto é, de um paraíso que é um inferno, e com o convite ao leitor para a aniquilação recíproca. O rito não teve êxito. Não obstante, o livro preserva a estrutura ritual, de modo que não termina sem um rito de saída, que prepara a passagem do sagrado para o profano. Depois da eucaristia sinistra de "Os carnívoros", o poeta inclui um poema curto, uma dedicatória a uma entidade míticoalegórica - a Saudade do Lar:

\footnotetext{
"Este livro é teu, Saudade

do lar; única fada que, espero, concitará os homens ao mútuo perdão, fazendo das trincheiras e das arenas de batalha a mais trágica das solidões."
} 
O poeta já não conta mais com a força mágica de sua poesia ou com o princípio místico da renovação da natureza. Não deixa, contudo, de oferecer seu livro de estréia, num derradeiro gesto sacrificial, a uma espécie de divindade, fada Saudade, depositando sua esperança, uma vez mais, em uma solução mágico-religiosa para as contradições histórico-sociais.

Com efeito, o sacrifício relaciona-se, em Há uma gota de sangue, à tomada de consciência da necessidade de participar dos problemas históricos: “Hoje não há mais o ontem em que fomos espectadores", diz o poeta na "Explicação" que precede a obra. Nesse sentido, em carta de 1935, Mário recorda que a publicação teve uma natureza sacrificial - ela representou o sacrifício da qualidade e da liberdade artística do livro: "Fazia já muitos anos que eu escrevia versos e contos, só contos e versos, quando em 1917, violentado pela Guerra, desesperado por ver os homens inimigos entre si, escrevi de repente uma série de versos de intenção manifestamente pacifista, e publiquei-os, $H a ́$ uma gota de sangue em cada poema. Eram versos que, no tempo, eu não achava ruins, hoje acho. Porém, mesmo então, eu sabia, conscientemente sabia que na minha coleção vastíssima de inéditos, estavam sonetos, principalmente sonetos, muito melhores que aqueles versos. Esses sonetos, os versos inéditos, eu fizera sempre dentro do destino do artista, buscando livremente a perfeição. Mas aqueles, os do livro publicado, clamavam o horror da guerra, da inimizade entre os homens, do saque de Lovaina"159. Como se verá na próxima parte deste trabalho, na obra de Mário de Andrade, o engajamento, que está na base do projeto estético do escritor, se realizará sempre como experiência sacrificial; mesmo o trabalho mais "comunista" de Mário, a ópera Café, última obra das Poesias completas, tem no seu núcleo o modelo do sacrifício cristão, associado ao complexo dos ritos de vegetação. A participação da literatura nas questões sociais nunca deixará de assumir, na arte marioandradina a forma de uma participation mystique. Nesse sentido, Há uma gota de sangue em cada poema, primeiro livro de poesia de Mário, situado pelo escritor entre as suas "obras imaturas", constitui uma espécie de rito 
de entrada ou de limiar, em que é selado com o leitor um pacto de sangue, do vasto rito sacrificial que é o conjunto da sua obra poética. 
Parte II 


\section{$\underline{\text { A Paixão }}$}

"Senhor, faze de mim um Jesusinho pesadíssimo"

Mário de Andrade, "Reza de fim de ano".

"Tudo pra mim são imediatamente paixões"

Mário de Andrade, Carta a Carlos Drummond de Andrade [1930]. 
Ao assimilar em sua estrutura mesma o sacrifício, Há uma gota de sangue em

cada poema dá forma a uma das experiências decisivas do pensamento estético de

Mário e a um dos temas essenciais de sua obra literária, em particular de sua poesia.

Inúmeras vezes, em sua extensa correspondência, o escritor afirma fundar-se a sua

atividade intelectual na prática constante do sacrificio. Em carta de 1925, por exemplo,

ao discutir o destino que havia dado a sua produção artística, ele escreve a Manuel

Bandeira, seu principal interlocutor em questões ligadas à literatura: "Não posso

compreender essa história de escrever para ficar. Porém nunca me desagradou, ao

contrário, me agrada mais pensar que o que estou escrevendo é pros outros. Aquela frase

do Machado, 'alguma coisa é preciso sacrificar', me rebate todo dia na memória"160.

${ }^{160}$ Andrade, Mário de. Correspondência - Mário de Andrade \& Manuel Bandeira, op. cit., p. 232. Quase vinte anos depois, em carta de 1944 a Guilherme Figueiredo, Mário evocaria a mesma frase machadiana: “'Alguma coisa é preciso sempre sacrificar', como falou Machado de Assis numa frase que me impressionou desde a primeira vez que li e nem sei em que livro dele está. [...] Isto sim é que você carece apurar: adquirir uma finalidade decidida, nítida e decisória. A qual, neste momento da vida, eu creio, Guilherme, que só pode ser interessada. E mesmo de alguma forma politicamente interessada". Andrade, Mário de. A lição do guru (cartas a Guilherme Figueiredo, 1937-1945), Rio de Janeiro: Civilização Brasileira, 1989, pp. 86-87. A frase de Machado de Assis a que Mário de Andrade se refere encontra-se em Helena, na cena em que Estácio mostra a Helena uma carta de amor que recebera de Eugênia, sua futura noiva. Percebendo que o rapaz não está seguro de seus próprios sentimentos, Helena procura fortalecer-lhe a intenção de pedir a mão da moça: "O casamento não é uma solução, penso eu; é um ponto de partida. O marido fará a mulher. Convenho que Eugênia não tem todas as qualidades que você desejaria; mas, não se pode exigir tudo: alguma coisa é preciso sacrificar, e do sacrifício recíproco é que nasce a felicidade doméstica" [grifo meu]. Vale notar que o próprio gesto de Helena, ao aconselhar Estácio a casar-se com Eugênia, é um gesto sacrificial, pois ela ama o rapaz e sabe que ele, no fundo, também a ama. O romance se passa no Segundo Reinado, portanto na sociedade escravocrata brasileira de meados do século XIX, na qual a população livre, mas despossuída, dependia dos favores dos proprietários para sobreviver, pois que praticamente não havia mercado de trabalho. Conforme demonstrou Roberto Schwarz, os motivos do sacrifício de Helena vinculam-se à diferença de classe social existente entre Helena - livre, mas pobre - e Estácio - jovem de família rica e distinta. A situação constitui um obstáculo que não é instransponível no paternalismo "esclarecido", mas cuja superação, por meio do acolhimento da moça pobre no seio da família rica, sublinha o desamparo daquela, na medida em que tem o sentido de um obséquio concedido pelos bem-nascidos, típico das relações de dependência pessoal, naturalmente indignas para o dependente, pelo menos do ponto de vista do individualismo moderno. Como se sabe, ao final do romance, Helena sacrificará seu amor e, com ele, a própria vida, para evitar a humilhação implicada na cooptação paternalista, em particular para fugir à suspeita provável, por parte da família de Estácio e da alta sociedade fluminense em geral, de que seu amor apenas disfarça o desejo de ascensão social. O sacrifício significa, nesse contexto, a renúncia dos favores oferecidos pelas elites, sem os quais, na sociedade escravocrata, praticamente não havia vida. Em outras palavras, na sociedade paternalista, a solução sacrificial apresenta-se como recurso extremo, único mesmo, que permite ao pobre preservar sua dignidade pessoal. Sobre esse beco-sem-saída social em que se viam os pobres no Brasil oitocentista, escreveu Roberto Schwarz: “O favor é a norma, o favor é insuportável, e fora do favor só existe a miséria. Na palavra de outro mestre nestes meandros, Guimarães Rosa, viver é quase impossível" [grifo meu]. Guardadas as diferenças histórico-sociais entre o Rio de Janeiro de 1850 e a São Paulo dos anos 1920, Mário de Andrade também estuda, no romance Amar, verbo intransitivo, as ambigüidades degradantes a que estão submetidos os não-proprietários, nas suas relações com a classe dominante, em uma sociedade burguesa e pré-burguesa ao mesmo tempo. Elza, ou Fräulein, jovem professora alemã de música e artes, é também, por força das circunstâncias econômico-sociais, professora de amor. Contratada como governanta para iniciar um adolescente da burguesia paulista na vida sexual, Elza ademais ensina piano e línguas ao rapaz e a suas irmãs. Desse modo, ela encarna as contradições da posição do intelectual e do professor que devia, nas relações que mantém com a elite emergente de São Paulo, aviltar-se para sobreviver. Autônoma, mas dependente, Fräulein acalenta o ideal de um amor 
Escrever "pros outros", no contexto do pensamento de Mário de Andrade, significa fazer literatura que tenha utilidade social imediata. Como se sabe, a evolução da teoria estética marioandradina é marcada pela convicção, progressivamente arraigada, de que a arte deve servir à humanidade, ou seja, de que ela deve participar do momento histórico e ter uma eficiência real.

Movido por essa certeza, após a deflagração da Segunda Guerra Mundial, Mário abandonou, já no fim da vida, a composição do romance Quatro pessoas, um estudo das relações sentimentais entre quatro personagens burgueses, que se encontrava em estado avançado e de que restam grandes fragmentos ${ }^{162}$ : "Quando começou a arrancada alemã, fiquei envergonhado de estar escrevendo romance fazendo crochet sobre a psicologia de quatro pessoas e parei tudo"163; "Não era mais possível preocupar-me com o destino de quatro indivíduos - envolvidos em dois casos de amor - quando o mundo sofria tanto"164. Oneyda Alvarenga escreveu sobre o caso: "Mário de Andrade não podia mais continuar tecendo aquele tricô psicológico em torno de quatro burguesinhos, enquanto o mundo se destruía e o homem corria perigo"165. Para ele, o problema fundamental do

romântico e procura preservar o orgulho concebendo sua "profissão" nos moldes de uma moderna prestação de serviços - uma racionalização semelhante à que recorrem os agregados dos romances machadianos para salvaguardar a auto-imagem. Trata-se, contudo, de compensações imaginárias. A humilhação real persiste e o anseio de Elza por uma vida livre e digna consuma-se em um grito expressionista, grito de libertação e de morte, de paroxismo de prazer e de dor, ápice de um processo de auto-aniquilação gozosa, em que Fräulein se imagina dissolvida no inorgânico e consumida pelo mesmo fogo sacrificial que matou Brunilda. Em Amar, verbo intransitivo, assim como em Helena, o tema do sacrifício relaciona-se, portanto, a tensões sociais específicas da formação histórica brasileira. Sob formas distintas, a solução sacrificial se encontra no centro de romances fundamentais de nossa literatura, como O guarani, Lucíola, Iracema, Dom Casmurro, Esaú e Jacó, Macunaíma, São Bernardo, Grande sertão: veredas, Fogo morto, A paixão segundo G. H., entre outros. Ver Andrade, Mário de. Amar, verbo intransitivo, Belo Horizonte/ Rio de Janeiro: Villa Rica, $16^{\mathrm{a}}$ edição, pp. 118-122. Assim, Machado de. Helena, Edições Críticas de Obras de Machado de Assis, Rio de Janeiro: Civilização Brasileira, 1977, p. 104. Schwarz. Roberto, Ao vencedor as batatas, op. cit., pp. 117-149.

${ }^{162}$ Andrade, Mário de. Quatro pessoas (edição crítica de Maria Zélia Galvão de Almeida), Belo Horizonte: Itatiaia, 1985.

163 Andrade, Mário de. Mário de Andrade-Oneyda Alvarenga: cartas, São Paulo: Duas Cidades, 1983, p. 234. Em outra carta a Oneyda Alvarenga, Mário se refere ao romance, ainda sem condená-lo, como "uma dessas coisinhas de preocupaçõezinhas morais de quatro pessoínhas burguesas sem importância”. Op. cit. P. 216.

164 Em entrevista de 1943 a Mário da Silva Brito, para o Diário de São Paulo. Andrade, Mário de. Entrevistas e depoimentos (edição organizada por Telê Porto Ancona Lopez), São Paulo: T. A. Queiroz, 1983, p. 96.

165 Alvarenga, Oneyda. "Sonora Política”, in Mário de Andrade, um pouco, Rio de Janeiro: José Olympio, 1974, p. 78. Note-se que a decisão marioandradina de participar baseia-se em um sentimento de urgência semelhante ao que disparava os "alarmes de incêndio" de Walter Benjamin: "Antes que a centelha chegue à dinamite, é preciso que o pavio que queima seja cortado". Benjamin, Walter. "Alarme de incêndio", in Obras escolhidas, volume II - Rua de mão única, São Paulo: Brasiliense, 2000. 
escritor colocava-se, nos momentos críticos da história, de modo semelhante à forma como Sartre o formulou, em sua conhecida profissão de fé da literatura engajada: "Trata-se de saber a respeito de que se quer escrever: de borboletas ou da condição dos judeus"166. Diferentemente do filósofo e escritor francês, contudo, Mário considerava e vivia essa questão como um penoso dilema, como uma situação dramática, trágica, em que a opção pela arte "interessada", conforme ele dizia, em detrimento da "arte pura", implicava sacrificios dolorosos para o artista.

*** O sacrifício do valor estético da obra de arte

Antes de tudo, Mário de Andrade entende, como se pode depreender do trecho de sua carta a Manuel Bandeira transcrito acima, que a obra de arte torna-se socialmente útil às expensas de sua qualidade estética. $\mathrm{O}$ escritor que almeja contribuir diretamente para o "melhoramento político-social do homem"167 tem de renunciar à "pretensão de ficar", ou seja, à intenção de criar obras que tenham valor artístico duradouro. Em uma entrevista concedida a Francisco de Assis Barbosa em 1944, Mário de Andrade expôs claramente essa opinião: “A responsabilidade do artista para com o seu público é que é difícil, esta é que lhe impõe mil sacrifícios (de que não é o menos doloroso, reconheço,

\footnotetext{
166 Sartre, Jean-Paul. O que é a literatura?, São Paulo: Ática, 2004, p. 23. Adorno critica essa concepção: "Entre as mediações da arte e da sociedade, a mediação temática, o tratamento de objetos aberta ou veladamente sociais, é a mais superficial e a mais enganadora. [...] Denúncia real é provavelmente apenas uma capacidade da forma, que é negligenciada por uma estética social que acredita em temas. Socialmente decisivo nas obras de arte é o que, a partir do conteúdo, se exprime nas estruturas formais". Ao contrário de Sartre, que dá à forma literária uma importância secundária em seu manifesto, Mário de Andrade, como se sabe e se verá adiante, não restringiria sua tentativa de aproximar arte e sociedade à tematização de conteúdos sociais, mas procuraria sistematicamente assimilar, em suas obras, as mais variadas formas da arte popular brasileira, na intenção de "enformar" apropriadamente a matéria histórica nacional. Não obstante, o assunto, o tema literário, não deixava de ser, para o escritor, o elemento mais importante da literatura que visa a participar da história: "O assunto é principalíssimo, e o essencial, porque ele é que nos coletiviza". Andrade, Mário de. "Distanciamentos e aproximações", in Música, doce música, op. cit., p. 354. Para a citação adorniana, ver Adorno. Theodor W. Teoria Estética, Lisboa: Edições 70, 2000, p. 258.

167 A expressão é empregada por Mário de Andrade na célebre conferência "O movimento modernista", na qual Mário, ao criticar o absenteísmo dos modernistas, seu alheamento aos problemas históricosociais, seu caráter "aristocrático" e suas relações comprometedoras com a oligarquia cafeeira paulista, significativamente afirma: "Ninguém pensava em sacrificio". Andrade, Mário de. "O movimento modernista", in Aspectos da literatura brasileira, Belo Horizonte: Itatiaia, 2002, pp. 261, 280, grifo meu.
} 
o sacrifício de sua própria arte), esta responsabilidade é que impõe o exercício do seu não-conformismo"'168.

A esse penoso sacrifício, Mário de Andrade afirma ter-se submetido, sistemática e conscientemente, em todo o seu trabalho literário: "Orientei toda a minha obra pra uma utilidade momentânea, mesmo com sacrifício de qualquer idéia de perfeição"169. Em sentido análogo, Mário escreveu a Drummond: "Toda a minha obra é transitória e caduca, eu sei. E eu quero que ela seja transitória. Com a inteligência não pequena que Deus me deu e com os meus estudos, tenho a certeza de que poderia fazer uma obra mais ou menos duradoura" 170 .

Este aspecto da lógica sacrificial presente nas reflexões do escritor sobre a relação entre os valores político e estético da obra de arte não podia escapar à crítica: "Mário acedera em sacrificar a beleza permanente das suas criações pela utilidade transitória delas", escreveu Oneyda Alvarenga, pouco após a morte do escritor ${ }^{171}$. Ainda nessa linha, Jorge Coli e Luiz Dantas, em prefácio para a segunda edição d'O banquete, observaram: "Ao problema do engajamento do artista e da função política da arte ela mesma se associa, em Mário, a noção de sacrifício: a arte deve almejar servir e não ser a obra-prima eterna, para a posteridade. Ao contrário, um dos modos essenciais do empenho é o sacrifício à transitoriedade"172. Jorge Coli foi, justamente, quem deu maior atenção ao tema do sacrifício na vida, no pensamento e na obra de Mário de Andrade. Em seu livro Música final, Coli identifica, no autor de Macunaíma, uma "característica vocação sacrificial", que é considerada pelo crítico como "um dos motores constantes nos comportamentos e posições de Mário de Andrade"173. Não obstante, apesar de ter

\footnotetext{
168 Andrade, Mário de. Entrevistas e depoimentos (edição organizada por Telê Porto Ancona Lopez), São Paulo: T. A. Queiroz, 1983, p. 108, grifo meu.

169 Andrade, Mário de. Cartas a Murilo Miranda (1934-1945), Rio de Janeiro: Nova Fronteira, 1981, p. 37.

${ }^{170}$ Andrade, Mário de. A lição do amigo (anotadas pelo destinatário), Rio de Janeiro: José Olympio, 1982, pp. 5-6.

${ }^{171}$ Alvarenga, Oneyda. Op. cit., p. 101.

172 "Sobre O banquete", in Andrade, Mário de. O banquete, op. cit., p. 32.

${ }^{173}$ Coli, Jorge. Op. cit., p. 188.
} 
sido registrado por uma parte da crítica, o sacrifício marioandradino, até onde saiba, ainda não foi posto em perspectiva e interpretado.

Em favor da funcionalidade social de sua produção artística, Mário de Andrade afirma ter renunciado ao que entendia como "perfeição estética" desde os inícios de sua atividade intelectual. Como vimos na primeira parte deste trabalho, de acordo com o escritor, já a decisão de publicar Há uma gota de sangue em cada poema, seu primeiro livro, envolveu um sacrifício dessa natureza - vale a pena citar novamente a passagem: "Fazia já muitos anos que eu escrevia versos e contos, só contos e versos, quando em 1917, violentado pela Guerra, desesperado por ver os homens inimigos entre si, escrevi de repente uma série de versos de intenção manifestamente pacifista, e publiquei-os, $H a ́$ uma gota de sangue em cada poema. Eram versos que, no tempo, eu não achava ruins, hoje acho. Porém, mesmo então, eu sabia, conscientemente sabia que na minha coleção vastíssima de inéditos, estavam sonetos, principalmente sonetos, muito melhores que aqueles versos. Esses sonetos, os versos inéditos, eu fizera sempre dentro do destino do artista, buscando livremente a perfeição. Mas aqueles, os do livro publicado, clamavam o horror da guerra, da inimizade entre os homens, do saque de Lovaina." ${ }^{174}$ Conforme o leitor terá percebido, Mário pressupõe em algum grau, nesse breve trecho de carta, uma antinomia entre a utilidade social e a plena elaboração formal das obras de arte, como se a destinação prática e coletiva da criação artística constrangesse a liberdade criadora, principal responsável pelo primor das obras ${ }^{175}$. Com efeito, o belo - a qualidade estética

\footnotetext{
174 Andrade. Mário de, Mário de Andrade escreve cartas a Alceu, Meyer e outros, op. cit., pp. 146-147, grifo meu. O dilema que se impõe ao escritor no momento da publicação de suas obras é discutido em três artigos de 1931, significativamente intitulados "O castigo de ser", nos quais Mário analisa a necessidade de o artista escolher entre publicar as obras que sua consciência pessoal considera belas e as obras que sua consciência social considera úteis: "É de todo inútil o artista publicar apenas obras que ele julgue conscientemente ótimas. Se ele se satisfaz com essa lealdade de consciência pessoal é porque é um individualista medonho, um vaidoso de si; consciente ou inconscientemente é um vaidoso que não sabe ter o verdadeiro orgulho capaz de sacrificios, é um torre-de-marfim, é um egoísta, um egocêntrico, um ser dessocializado. [...] O ideal seria então o artista só publicar aquilo que a sua consciência social reputa bom [no sentido de útil] e a sua consciência pessoal reputa belo? É um engano. Porque ambas estas duas consciências são contraditórias. Quem tem a segunda é um egoísta, se indiferentiza no individualismo e não pode obter a primeira. E esta primeira despreza a segunda e a repudia. A lealdade pra com a consciência social é a única que nobilita o artista e o justifica satisfatoriamente em sua humanidade". Andrade, Mário de. "O castigo de ser - II", in Táxi e crônicas do Diário Nacional, Belo Horizonte: Itatiaia, 2005, p. 370, grifo meu.
}

175 "Sucede às vezes, raríssimas vezes, que as precisões mais ou menos práticas da sociedade humana, coincidem com a arte... [...] A natureza tem deduções estéticas que a criação e a necessidade humana às mais das vezes contradizem". Andrade, Mário de. "Cristo-Deus", crônica publicada no Diário Nacional em 1931, in Táxi e crônicas do Diário Nacional, op. cit., 2005, p. 355. 
- é entendido por Mário de Andrade como o componente puramente hedonístico da arte, como o fator que distancia a obra - e seu público - da práxis, como o elemento que, por si, não proporciona conhecimento da vida humana ${ }^{176}$. Na série de três crônicas que escreveu em 1929 sobre a participação da noção de "desinteresse" no conceito de arte, Mário afirma: "A gente se servindo da Beleza pra criar a obra-de-arte e atingir a Arte enfim, não faz mais do que empregar um elemento que fortifique a função de desinteresse que a Arte tem. A beleza artística (que não tem nada que ver com a beleza natural) não é senão mais um meio com que a gente consegue tornar desinteressada a obra-de-arte e a Arte"177.

Para Mário de Andrade, portanto, fazer arte "interessada" supõe sacrificar, em alguma medida, o valor estético da criação artística. Nesse ponto, pode-se dizer que ele, provavelmente o escritor brasileiro que mais apaixonadamente se dedicou a estabelecer relações entre a arte e a práxis - algumas vezes com resultados extraordinários, como em Macunaíma -, não conseguiu libertar-se da "dicotomia por um lado, por outro lado", a que Walter Benjamin se referiu como sendo característica de uma reflexão nãodialética sobre a questão: "por um lado, devemos exigir que o autor siga a tendência política correta, e por outro lado temos o direito de exigir que sua produção seja de boa qualidade" ${ }^{178}$. Na maioria das vezes em que Mário aborda teoricamente o assunto - em cartas, entrevistas ou artigos -, qualidade estética e conteúdo social da obra de arte aparecem como elementos estranhos e, em muitos casos, opostos um ao outro.

Assim, no pensamento marioandradino, a noção de beleza, de perfeição formal, costuma associar-se à idéia da "torre-de-marfim", ou seja, às marcas de isolamento e de ineficácia habitualmente atribuídas aos artistas clássicos: “O destino real dos grandes artistas é aquela permanência após a morte, aquela atividade certamente mais fecunda e menos propriamente humana que divina, de criar o descanso, o prazer, a evasão deste

\footnotetext{
176 Andrade, Mário de. Introdução à Estética musical (estabelecimento do texto, introdução e notas de Flávia Camargo Toni), São Paulo: Hucitec, 1995, pp. 15-35.

177 Andrade, Mário de. “Desinteresse - II”. In Táxi e crônicas do Diário Nacional, op. cit., p. 97.

178 Benjamin, Walter. "O autor como produtor", in Obras escolhidas, volume I-Magia e técnica, arte e política, São Paulo: Brasiliense, 2008, p. 121.
} 
mundo que a Beleza dá"179. Para Mário, portanto, é como se ao artista se impusesse uma angustiosa alternativa: "clássico ou eficaz?"180. Como se sabe, contra suas inclinações mais próprias e sua formação fin de siècle, Mário toma o partido da eficácia social da obra de arte. Diz o compositor Janjão, porta-voz de Mário de Andrade n'O banquete:“'O humano, o utilitariamente humano, é o que eu pretendo. Não o 'humano' acomodativo dos artistas que tudo convertem a valores gerais, os 'valores eternos', mas o combativo e transitório. Mesmo o transitório, mesmo a arte de circunstância, morta cinco anos depois. Que valor mais terá esse 'Esquerzo Antifachista', depois que Mussolini virou pó de traque? Nenhum. Nem me interessa que tenha mais algum"181. Uma compreensão dialética das relações entre a qualidade estética e a função social da criação artística decerto reconheceria, em sentido contrário ao da antinomia marioandradina, que "a tendência política correta de uma obra inclui sua qualidade literária"182, ou que "não há obra de arte cuja consciência social é verdadeira que não se prova em termos de qualidade estética"183.

A ausência da dialética entre os conceitos do belo - entendido como resultado da elaboração formal - e do social na arte levou o escritor brasileiro a assumir, algumas vezes, em seu período mais engajado, a partir dos anos 1930, posições antivarguardistas que, em certos aspectos, lembram a hostilidade de Lukács em relação ao modernismo ${ }^{184}$. Assim como o grande crítico húngaro, Mário de Andrade acusa a arte moderna de ser formalista e alheia à realidade, além de pouco acessível e útil às massas - considerando-a inclusive, como o Lukács de "Narrar ou descrever", uma manifestação

\footnotetext{
${ }^{179}$ Em carta de 1935 escrita a Sousa da Silveira. Andrade, Mário de. Mário de Andrade escreve cartas a Alceu, Meyer e outros, op. cit., p. 149.

180 A formulação é de Bernard Dort e refere-se a Brecht. Ver, do autor, O teatro e sua realidade, São Paulo: Perspectiva, 1977, p. 344. Sobre as relações entre classicidade e eficácia social em Brecht, ver o estudo de José Antonio Pasta Júnior, Trabalho de Brecht (breve introdução ao estudo de uma classicidade contemporânea), Sâo Paulo: Ática, 1986.

${ }^{181}$ Andrade, Mário de. O banquete, op. cit., pp. 68-69.

182 Benjamin, Walter. Op. cit., p. 122-123, grifo meu.

${ }^{183}$ Adorno, Theodor W. Teoria Estética, op. cit., p. 349.

184 Ver, em particular, o ensaio polêmico escrito por Lukács em 1938, “Trata-se do realismo!”, in Machado, Carlos Eduardo Jordão. Um capítulo da história da modernidade estética: debate sobre o Expressionismo, São Paulo: Editora da UNESP, 1998, pp. 195-231.
} 
da burguesia em seu estágio de decadência, ao enaltecer em Shostakovich, o "repúdio ao esteticismo individualista deliqüescente da música burguesa contemporânea"185. Já em 1923, porém, na significativa data de 15 de novembro, em uma carta que tem o tom de um manifesto nacionalista, Mário escrevia sobre o cubismo a Tarsila do Amaral, que se encontrava em Paris, assimilando as vanguardas européias: "Abandona o Gris e o Lhote, empresários de criticismos decrépitos e estesias decadentes!"186.

Na poesia, o verso livre, ostensivamente defendido por Mário de Andrade nos primeiros anos do modernismo, começa a ser visto pelo escritor, a partir de meados da década de 1920, sob uma perspectiva negativa, como "uma vitória do individualismo". Ao mesmo tempo, o ritmo medido é revalorizado como uma técnica de alto "poder socializante". Por isso, quando a preocupação com a nacionalização e a função social da arte passa a orientar a sua produção literária, pouco tempo depois da Semana de Arte Moderna, Mário de Andrade volta a empregar em muitos de seus poemas os ritmos tradicionais. Em carta de 1944 a Guilherme Figueiredo, comentando os poemas da Lira paulistana, disse Mário: "A rima e o metro têm razão, têm motivo imemorial coletivo. [...] Pra obter uma eficiência mais larga, mais geral, de combate, é preciso abandonar o individualismo do verso-livre, e usar do coletivismo marcial ou cancioneiro dos metros e suas conseqüências rítmicas em que a consonância se inclua"187.

Com base, portanto, na consciência aguda do distanciamento social entre a arte contemporânea e as massas populares, Mário questiona, não sem alguma razão, o valor social imediato das vanguardas, mas sempre pressupondo a separação entre o estético e o social (social a que Mário de Andrade, no trecho a seguir, refere-se como "artístico", o que assinala a existência de outra polarização teórica problemática, estabelecida muitas

185 "Introdução a Shostakovich" [1945], in Coli, Jorge. Música final: Mário de Andrade e sua coluna jornalística Mundo musical, Campinas: Editora da Unicamp, 1998, p. 396-407. Em "Narrar ou descrever", Lukács defende a idéia de que um ramo da prosa moderna, seu ramo propriamente moderno, que se inicia em Flaubert e culmina em Joyce e John dos Passos, constitui uma manifestação artística da decadência burguesa. In Lukács, Georg. Ensaios sobre literatura, Rio de Janeiro: Civilização Brasileira, 1968, pp. 47-99.

186 Andrade, Mário de. Correspondência - Mário de Andrade \& Tarsila do Amaral, op. cit., pp. 78-79. Vinícius Dantas estuda as proposições dessa importante carta escrita por Mário a Tarsila no artigo "Entre “A negra' e a Mata Virgem", in Novos Estudos CEBRAP, nº 45, São Paulo: julho de 1996, pp. 100-116.

187 Andrade, Mário de. A lição do guru (cartas a Guilherme Figueiredo, 1937-1945), op. cit., p. 107. Ver também "A poesia em 1930", in Aspectos da literatura brasileira, Belo Horizonte: Itatiaia, 2002, pp. $38-40$. 
vezes pelo escritor, entre "artístico" e "estético"): "Esse distanciamento [entre a arte contemporânea e as massas populares] atingiu tal e tão abstruso exaspero que é muito difícil estabelecer que função artística (não falo função 'estética', mas exatamente 'artística') podem exercer as criações exacerbadamente 'hedonísticas' de um Léger na pintura, de um Schoenberg na música, como de um Joyce na literatura"188.

De acordo com o argumento de Mário, a elaboração estética radical, a realização integral das potencialidades históricas do material artístico tende a diminuir o potencial de crítica social da arte moderna ${ }^{189}$. Levando o raciocínio às últimas conseqüências, é possível afirmar que, no contraditório quadro teórico de Mário de Andrade, a crítica da sociedade não é reconhecida como imanente à organização formal da obra de arte. Por essa razão, e não por reacionarismo, após os "anos heróicos" do Modernismo, os anos de luta pela atualização estética da arte brasileira, Mário recusará a pintura abstrata, com base nos princípios do nacionalismo e do engajamento político: "[Os pintores abstratos] realizam o Belo. Porém Belo paupérrimo porque se realiza unicamente com os fatores formais dele. [...] Por isso os Kandinskis, os Legers morrem de pobreza"190.

Por razões semelhantes, Mário de Andrade rejeitará a música pura e defenderá a união da palavra ao som, com o objetivo de dar à arte musical uma significação política que ela, por si mesma, não tem: "Se a música instrumental é de fato desumanamente pura, pois nos utilizemos dos elementos externos que a humanizam! Antes de mais nada, existe a voz que destina a música e as músicas. E com efeito, em épocas como a nossa, a música devia se tornar quase que exclusivamente vocal. [...] Mas há outros elementos que só podem repugnar ao grã-fino esteticóide. Há os títulos, há os prefácios,

\footnotetext{
188 Andrade, Mário de. "Distanciamentos e aproximações", in Música, doce música, op. cit., pp. 351-355.

189 Também reconhecendo o afastamento da "nova música" em relação à realidade social, porém compreendendo-o dialeticamente, ou seja, como negação determinada do real, Adorno escreve, em sentido contrário ao da interpretação de Mário de Andrade: "A nova música, em seu suposto esoterismo, não quer apenas ajudar a exprimir-se o conteúdo social que a linguagem da sociedade esconde. Ela comunica por meio da não-comunicação. [...] A posição crítica que a nova música adota no plano estético é, ao mesmo tempo, objetivamente, uma posição social". Adorno, Theodor W. "Musique et nouvelle musique", in Quasi una fantasia, Paris: Gallimard, 1982, pp. 276, 285.
}

190 Andrade, Mário de. Introdução à Estética musical, op. cit., p. 32, grifo meu. No ensaio "Vanguarda e nacionalismo na década de 20", Gilda de Mello e Souza analisa a revisão crítica das vanguardas realizada por Mário de Andrade durante sua fase nacionalista. Ver Souza, Gilda de Mello e. Exercícios de leitura, São Paulo: Duas Cidades, 1980, pp. 249-277. 
há entrevistas nos jornais"191. Em outras palavras, a música, por meio de sua estruturação formal apenas, não critica a sociedade. Para fazê-lo, precisa de elementos externos a ela e que determinem o sentido do som, para que este possa dizer algo.

$\mathrm{Na}$ base do argumento, como o leitor terá percebido, está a idéia de que, nas obras de arte, a denúncia da injustiça social é própria do conteúdo, não da forma. Nesse contexto, a música atonal, considerada por Mário de Andrade a realização plena do princípio da música pura ${ }^{192}$, será especialmente criticada pelo escritor. Na "Introdução a Shostakovich", Mário aprovará o "tonalismo decidido" do compositor russo e pleiteará, em páginas que lembram Platão, a reabilitação do ethos na música ${ }^{193}$. A inspiração platônica dos juízos estético-políticos de Mário sobre a música revela-se por completo

${ }^{191}$ Andrade, Mário de. "Elegia”, artigo reproduzido em Coli, Jorge. Música final, op. cit., pp. 108-111.

192 Andrade, Mário de. Pequena história da música, Belo Horizonte: Itatiaia, 1987, pp. 202-203.

193 Como se sabe, a noção de ethos musical ocupa um lugar central nas reflexões platônicas sobre a música. Sob forte influência das doutrinas pitagórica e damoniana, Platão compreende a música como uma arte intimamente relacionada à moral. Com base nessa relação e na teoria da forte influência da música sobre a alma - influência sobre a qual Mário de Andrade muito refletiu -, o pensamento musical de Platão constitui-se, principalmente, sob a forma de uma ética e de uma política musicais, por meio das quais o filósofo grego procura dirigir a produção musical de seu tempo, no intuito de preservar a coesão político-social da pólis. Assim, segundo a ética musical de Platão, "o bom compositor não deve visar ao prazer, mas ao melhoramento moral do ouvinte" - uma das convicções mais arraigadas de Mário de Andrade. Por isso, Platão exige dos compositores um elevado grau de consciência profissional, recomenda-lhes que evitem a perigosa ambigüidade da música pura e postula que a música deve ser sempre acompanhada por um texto. As semelhanças dessas propostas platônicas com o conjunto do trabalho de Mário de Andrade sobre a música brasileira saltam à vista - com a diferença, entre tantas outras, de que Platão almeja conservar a tradição musical grega, enquanto Mário procura instituir uma tradição musical brasileira. De todo modo, assim como o escritor paulista rejeita em grande medida as técnicas contemporâneas de composição, Platão recusa as novas formas e técnicas musicais que surgem em sua época, pois as considera socialmente nocivas. Em suma, partindo da idéia de que a música é uma arte essencialmente vinculada à ética, Mário de Andrade e Platão procuraram regulamentar a produção musical com base na idéia da função social da música, o que os levou a assumir posições muitas vezes parecidas a respeito de o que se deve e de o que não se deve compor. Finalmente, não custa lembrar que $O$ banquete, uma das obras fundamentais da "teoria estética" marioandradina, além de remeter expressamente, por meio do título, ao livro homônimo de Platão, é uma obra de feição marcadamente "platônica", tanto na sua forma - o diálogo - como no seu conteúdo - a discussão sobre a função do artista na sociedade, a tentativa de moralização do meio musical e a proposta de normatização da produção musical contemporânea tendo em vista a integração da sociedade. A aproximação entre o pensamento musical de Platão e o de Mário de Andrade aqui sugerida evidentemente não ignora as inúmeras diferenças existentes entre homens e teorias tão distantes no tempo. Diferentemente das reflexões marioandradinas, por exemplo, a doutrina musical de Platão faz parte de um sistema filosófico, ao qual ela se vincula por meio da idéia de "harmonia". Por sua vez, o projeto musical de Mário de Andrade supunha que suas propostas deveriam valer apenas enquanto durasse o período de nacionalização da música brasileira, ou seja, enquanto a música brasileira não se tivesse consolidado como arte caracteristicamente nacional. As principais reflexões de Platão sobre a música encontram-se nas duas grandes obras políticas do filósofo grego, o que assinala, por si, a importância social que tem a música no pensamento platônico. Ver Platão, As leis, livros II, III e VII, São Paulo: Edipro, 1999. Idem. A República, livros III e X, Lisboa: Calouste Gulbenkian, 2008. A citação sobre Platão feita acima encontrase em um estudo sobre as relações entre música, moral, educação, política e metafísica em Platão. Moutsopoulos, Evanghélos. La musique dans l'oeuvre de Platon, op. cit., p. 309; sobre a ética musical de Platão, pp. 159-265; 305-319. As idéias principais do projeto de nacionalização da música brasileira elaborado por Mário de Andrade encontram-se no Ensaio sobre a música brasileira [1928], Belo Horizonte: Itatiaia, 2006. 
na peremptória sentença lavrada no artigo polêmico "Ra-ta-plã", de 1944: “O compositor 'puro’ é um errado e um pernicioso que devia ser expulso da República”194. Nesse caso, naturalmente, é necessário levar em consideração o fato de que o autor de Macunaíma tinha o hábito de, como princípio de combate, "forçar a nota" ao defender seus pontos de vista ${ }^{195}$. Em outras palavras, Mário de Andrade sacrificava-se, fazia afirmações que não correspondiam exatamente a suas idéias, inclusive quando clamava a necessidade do sacrificio do artista.

Não obstante, a veemente recusa do desenvolvimento radical das possibilidades objetivas do material artístico na primeira metade do século XX, em nome da idéia de que a arte deve exercer a crítica das injustiças político-sociais, revela, assim como a concepção marioandradina do belo, do "estético", que Mário não conseguiu, apesar dos esforços desmedidos realizados por ele em sentido oposto, estruturar um sistema teórico em que as relações entre a arte e a sociedade fossem integralmente compreendidas de modo dialético. Em virtude disso, as intensas reflexões de Mário de Andrade sobre os vínculos sociais da criação artística quase invariavelmente conduzem à conclusão de que, para que a obra de arte tenha conteúdo social, sua forma deve ser sacrificada, seja por meio do sacrifício da qualidade estética, seja pelo sacrifício da experimentação técnica, quer dizer, das potencialidades históricas dos procedimentos composicionais afinal, Mário costumava associar as poéticas de vanguarda e o experimentalismo contemporâneo ao individualismo. Mário talvez reagisse dessa forma porque também as vanguardas, em grande medida, fizeram esse corte antidialético em sentido inverso, isto é, para avançar, "esqueceram” a terra.

Se a solução é propriamente sacrificial, como é o caso, a renúncia nela implicada não é pequena, muito pelo contrário. Como se sabe, Mário de Andrade tinha uma sensibilidade esteticamente muito exigente e refletiu sobre os problemas formais das artes - da literatura e da música em particular, mas também da pintura, da escultura, da

\footnotetext{
${ }^{194}$ Andrade, Mário de. "Ra-ta-plã”, in Coli, Jorge. Música final, op. cit., pp. 112-116.

195 "Mário é polêmico e provocador, e esse traço psicológico, muito nítido aliás em sua geração, leva freqüentemente à radicalização que não tem outro fim senão agitar posições, provocar e polemizar". Lafetá, João Luiz. 1930: a crítica e o Modernismo, São Paulo: Duas Cidades/Editora 34, 2000, p. 180.
} 
arquitetura e do teatro - com a mesma preocupação, rigor e freqüência com que pensou a necessidade de a arte participar das lutas sociais. Lêdo Ivo, em um ensaio em que há exagero, teve o mérito de assinalar a importância da forma para Mário de Andrade: "Sua vida é perseguida pela Forma, como num apólogo kafkiano"196. Com efeito, a partir do final da década de 1930, a questão da técnica torna-se mesmo uma das preocupações teóricas centrais do escritor. Em um artigo de 1939, por exemplo, Mário de Andrade afirma que "não há obra de arte sem forma e a beleza é um problema de técnica e de forma" 197 .

A contradição entre o valor estético e a função social da produção artística é, portanto, dramática para Mário - especialmente porque ele não se esquiva de instalar-se no centro dessa contradição e de experimentá-la em todos os seus aspectos, de maneira integral, inclusive fisicamente. O conflito é estudado de forma cuidadosa por João Luiz Lafetá, que o caracterizou como uma “tensão entre projeto estético e projeto ideológico", própria não apenas do pensamento marioandradino, mas do Modernismo brasileiro, e em torno da qual se articula a passagem da literatura e da crítica literária dos anos 1920 para os anos $1930^{198}$. Segundo o crítico, foi Mário de Andrade, entre os escritores e intelectuais de sua geração, quem mais aprofundou o problema:

"Armado da mais aguda consciência de sua arte e provido de uma convicção ética notável que o impelia sempre, como escritor, ao engajamento direto na realidade social, o autor de Macunaíma se apresenta dentro do Modernismo brasileiro com a pesquisa mais abrangente - e nesse sentido também a mais fecunda e atual - dos nossos rumos literários. [...] Mário vive com particular dramatismo a tensão entre sua sensibilidade de artista, cônscio das

\footnotetext{
196 Ivo, Lêdo. Lição de Mário de Andrade, Rio de Janeiro: Depto. de Imprensa Nacional, 1952, p. 4.

197 Andrade, Mário de. "A raposa e o tostão", in O empalhador de passarinho, Belo Horizonte: Itatiaia, 2002, p. 108 .

198 Ver Lafetá, João Luiz. Op. cit., pp. 153-224.
} 
exigências da escritura, e seus impulsos de intelectual à procura do melhor desempenho no papel de formador da nacionalidade e/ou no trabalho de construção social. Mas é exatamente a vivência dramática dessa tensão, encarada no dia-a-dia da prática literária e enfrentada com o rigor de honestidade que foi um dos princípios básicos de sua vida, é sobretudo a consciência alerta para tais problemas, para suas minúcias e sutilezas, que o torna tão distinto - tão à frente dos homens de sua época." 199

Contudo, apesar de se ter empenhado, como nenhum outro intelectual de seu tempo, em solucionar essas contradições, ou melhor, justamente - por razões históricas, como se verá - porque se dedicou a refletir honesta, apaixonada e profundamente sobre elas, levando essa reflexão às últimas conseqüências, Mário de Andrade não encontrou a solução dialética capaz de articular o estético e o político na arte: “O autor de 'Eu sou trezentos...' não obteve a síntese dialética que lhe permitisse solver o problema da divisão nítida entre arte, de um lado, e engajamento social do outro"200.

Isso não significa que o escritor não tenha intuído, em alguns momentos, uma mediação que operasse a síntese entre elaboração formal e compromisso sociopolítico. Conforme notou Lafetá, inspirado em Roberto Schwarz ${ }^{201}$, Mário esboça a possibilidade de superação da antinomia por meio da noção de "técnica pessoal", exposta em alguns de seus melhores ensaios tardios ${ }^{202}$. $\mathrm{O}$ autor de Macunaíma chegará inclusive a formular

\footnotetext{
${ }^{199}$ Idem. Ibidem, pp. 153-154.

${ }^{200}$ Idem. Ibidem, p. 183.

${ }^{201}$ Schwarz, Roberto. "O psicologismo na poética de Mário de Andrade", in op. cit., pp. 13-23. Nesse texto, Schwarz estuda a antinomia existente entre os conceitos de "lirismo" e "técnica" no pensamento estético marioandradino, antinomia resultante, segundo o crítico, das contradições do psicologismo característico da poética de Mário de Andrade. Conforme demonstra Schwarz, a síntese dessa polaridade é delineada por Mário em alguns de seus últimos trabalhos, nos quais o escritor propõe o conceito de "técnica pessoal", em que a técnica é compreendida como a condição de realização do lirismo, não como a negação deste.

202 A idéia de técnica pessoal é apresentada por Mário de Andrade em "O artista e o artesão", in $O$ baile das quatro artes, São Paulo: Martins, 1975, pp. 9-33. O conceito é exposto, também, em "Atualidade de Chopin", in op. cit., pp. 137-165 e "Elegia de abril", in Aspectos da literatura brasileira, op. cit., pp. 207-218, em especial as pp. 216-217.
} 
argumentos que se assemelham às idéias de Adorno, reconhecido mestre da dialética, sobre a relação entre a obra de arte e a sociedade:

"Mas por isso mesmo que pretende a beleza e a recria em sua criatura, o artista é o revoltado por excelência contra os defeitos e as feiúras da vida, contra todas as injustiças, as falsificações, contra as mentiras sociais, as desgraças todas." 203

"Imagino que uma verdadeira consciência técnica profissional poderá fazer com que nos condicionemos ao nosso tempo e o superemos. [...] Se o intelectual for um verdadeiro técnico da sua inteligência, ele não será jamais um conformista." 204

Nessas passagens, Mário de Andrade concebe, a seu modo, algo semelhante ao que Adorno, em sua crítica à arte engajada, chamou de "o a priori polêmico das obras de arte" 205 . Por isso, sem que se force a nota, pode-se dizer que, na capacidade de pensar o trabalho artístico de elaboração formal como tomada de posição político-social, ou seja, de compreender a forma estética como conteúdo histórico sedimentado 206 , ninguém foi mais longe, no Brasil da primeira metade do século XX, do que Mário de Andrade.

Todavia, essa profunda compreensão do teor social de verdade da obra de arte é apenas vagamente delineada pelo escritor. Em trabalhos posteriores, como nos textos sobre Mussórgski [1943], nos artigos "Elegia" e "Ra-ta-plã" [1944], e na "Introdução a

\footnotetext{
${ }^{203}$ Andrade, Mário de. “Atualidade de Chopin”, in O baile das quatro artes, op. cit., p. 146.

${ }^{204}$ Andrade, Mário de. "Elegia de abril”, in Aspectos da literatura brasileira, op. cit., p. 216

205 Adorno, Theodor W. “Engagement”, in Notes sur la littérature, Paris: Flammarion, 1999, p. 286.

206 Adorno, Theodor W. Philosophie de la nouvelle musique, op. cit. .
} 
Shostakovich" [1945], Mário de Andrade retorna ao seu esquema não dialético ${ }^{207}$. Desse modo, pode-se afirmar que ele não se livrou da concepção de que o estético e o social são essencialmente antinômicos. O exemplo mais expressivo da dificuldade de superar esse impasse encontra-se em uma passagem sobre Lasar Segall, na qual Mário de Andrade, no e pelo movimento mesmo em que procura dialetizar os termos, repõe a perspectiva antidialética, como se seu pensamento percorresse um círculo sem saída: "E por isso o artista consegue essa transfiguração que será porventura o maior destino da arte: dentro da beleza objetiva da técnica, dentro de uma verdade plástica da melhor qualidade, como que o desaparecimento mesmo de todo este valor estético que se põe humildemente ao serviço de um sentimento ideal. A perfeição técnica da obra deixa de existir, não porque não exista, mas porque jamais existe por si mesma. Ela deixa de existir porque é da sua mais exata missão jamais ser 'estética', jamais ser hedonística, desaconselhadamente livre em sua beleza, mas ser de fato 'artística', nos preservando no mundo da própria vida com suas dores fidelíssimas"208.

*** O sacrificio da Arte

Quanto mais se aprofundava no problema, Mário de Andrade mais se dilacerava. Seu pensamento estético, como disse Roberto Schwarz, é rasgado por polaridades irredutíveis ${ }^{209}$. De fato, a oposição entre valor estético e função social da criação artística cinde o próprio conceito marioandradino de arte. Em suas reflexões incessantes a respeito, Mário oscila vertiginosamente entre as idéias de que o desinteresse constitui a qualidade essencial da arte e de que esta é fundamentalmente interessada. No contexto do pensamento de Mário de Andrade, "desinteresse" significa a ausência de finalidade prática da obra-de-arte e de sua recepção, ou seja, a própria autonomia da arte. Por essa

\footnotetext{
207 Todos esses textos encontram-se reproduzidos em Coli, Jorge. Op. cit., pp. 83-95, 108-116 e 396-407.

208 Andrade, Mário de. "Lasar Segall” [1943], in Aspectos das artes plásticas no Brasil, Belo Horizonte: 1984, p. 61 .

209 Schwarz, Roberto. Ibidem. Telê Porto Ancona Lopez faz uma exposição da evolução do pensamento marioandradino sobre a função da arte e do artista. Ver, da Autora, Mário de Andrade: ramais e caminho, São Paulo: Duas Cidades, 1972, pp. 231-249.
} 
razão, o desinteresse é freqüentemente considerado por Mário o atributo essencial da arte - momentos nos quais as reflexões e os termos do escritor brasileiro curiosamente lembram o pensamento estético de Kant ${ }^{210}$ : "Se a gente generaliza a Arte pra chegar a um conceito essencial dela, a noção de Desinteresse avulta e se torna mesmo o elemento primordial da criação artística", escreve Mário em $1930^{211}$. Em sentido análogo, ao analisar o classicismo musical, o escritor afirma que "a Arte se caracteriza, entre as manifestações humanas, justamente por ser uma libertação da vida prática, isto é, por ser imediatamente desnecessária" ${ }^{212}$. Finalmente, nos esboços da Introdução à Estética musical, obra didática e teórica, com intenção de sistema, iniciada em 1921 e retomada em 1938, em que Mário de Andrade define os conceitos do Belo e da Arte, encontra-se a proposição sumária: "Da Arte. Definição: Arte é a expressão livre e sem interesse imediato do ser racional" 213 .

Por outro lado, em ocasiões não menos numerosas e decisivas, em trabalhos não menos representativos de suas idéias, o escritor conceitua a arte em sentido absolutamente contrário. $\mathrm{Na}$ conhecida conferência sobre o movimento modernista, Mário faz a seguinte afirmação - em que reaparece a dissociação entre o estético e o social na criação artística: "A liberdade da pesquisa estética lida com formas, com a técnica e as representações da beleza, ao passo que a arte é muito mais larga e complexa que isso, e tem uma funcionalidade imediata social, é uma profissão e uma força interessada da vida" 214 . A perspectiva foi invertida e a qüididade da arte, agora, é o interesse, a função prática, de natureza sociopolítica. Ao invés de ser uma manifestação que liberta e distancia do real, a arte é justamente um meio pelo qual o homem adere à

\footnotetext{
210 Para Kant, como se sabe, o belo se caracteriza, entre outras coisas, por ter uma "finalidade sem fim" e o juízo de gosto é, antes de tudo, desinteressado. Kant, Immanuel. Duas introduções à Crítica do Juízo (organização de Ricardo Ribeiro Terra), São Paulo: Iluminuras, 1995, pp. 106-128. Idem, “Analítica do Belo” (tradução de Rubens Rodrigues Torres Filho), in Os pensadores, São Paulo: Abril, 1972.

211 “Desinteresse". Idem. Ibidem, p. 95.

${ }^{212}$ Andrade, Mário de. Pequena história da música, Belo Horizonte: Itatiaia, 1987, p. 114.

${ }^{213}$ Andrade, Mário de. Introdução à Estética musical, op. cit., p. 21.

${ }^{214}$ Andrade, Mário de. "O movimento modernista”, in Aspectos da literatura brasileira, op. cit., p. 276.
} 
realidade: “Arte é uma forma de contato, é uma forma de crítica, é uma forma de correção. É uma forma de aproximação social”215.

A passagem que melhor ilustra esse desnorteante vaivém teórico está no próprio capítulo "Da Arte" da Introdução à Estética musical, citado logo acima. Após definir conceitualmente a arte como expressão desinteressada - "Definição: Arte é a expressão livre e sem interesse imediato do ser racional" -, Mário subitamente vira o conceito às avessas, separa o conceito de Arte do conceito de Belo e encerra o capítulo fazendo uma dura crítica à "arte-pura", afirmando que a Arte, antes de tudo, é uma forma interessada de expressão e de conhecimento da vida ${ }^{216}$. Sobre essa mudança súbita, Mário fez um comentário revelador, em carta a Moacir Werneck de Castro: "Vou conceituando a arte, conceituando, quando chego no conceito da 'liberdade' e independência total da arte, de repente dou um salto mortal, uma guinada que ninguém espera (nem eu esperava, relendo a coisa agora!) e termino a conferência concluindo que a arte é interessada" 217.

A noção de "salto mortal”, usada por Mário de Andrade para definir a passagem do conceito de "arte pura" para o de "arte interessada", parece-me cheia de significado. N'O banquete, o compositor Janjão exprime a mesma idéia: “Meu Deus! Meu Deus! que atitude tomar diante das formas novas, coletivas e socialistas da vida que encerram pra mim quase todas as vozes verdadeiras do tempo e do futuro? Mas vozes 'coletivas' que não interessam ao meu individualismo nem podem me fazer feliz ou desinfeliz? Mas de que tenho de participar, porque a isso me obriga a minha própria satisfação moral de indivíduo? [...] Pra mim as formas do futuro serão sempre um me atirar no abismo..."218.

\footnotetext{
${ }^{215}$ Andrade, Mário de. "Distanciamentos e aproximações", in Música, doce música, op. cit., p. 354.

${ }^{216}$ Andrade, Mário de. Introdução à Estética musical, op. cit., p. 21-32.

${ }^{217}$ Castro, Moacir Werneck de. Mário de Andrade: exílio no Rio, op. cit., p. 216, grifo meu.

218 Andrade, Mário de. O banquete, op. cit., pp.63, 65, grifo meu. Ao comentar as oposições irredutíveis do quadro conceitual marioandradino, Roberto Schwarz também faz referência a um salto - sem defini-lo, contudo, como "mortal" - como à única possibilidade de "superação" das contradições que ao mesmo tempo moviam incessantemente e paralisavam o pensamento de Mário de Andrade: "Sua reflexão habita como que um poço de paredes lisas, sem saída natural, no qual circula e do qual somente por um salto poderia escapar". Schwarz, Roberto. Op. cit., p. 19.
} 
No pensamento estético, na obra literária e na própria vida de Mário de Andrade, $o$ sacrifício é a mediação que permite a passagem do artístico para o social, do individual para o coletivo, da forma para o conteúdo e, na fase nacionalista, do universal para o local. Não há risco de exagero em afirmar que, da poesia à prosa, da crítica à epistolografia, do magistério à pesquisa do folclore e à administração do Departamento de Cultura, toda a atividade intelectual de Mário de Andrade funda-se na experiência do sacrifício. O duplo sentimento de que as contradições entre o estético e o político, o subjetivo e o social, o formal e o temático, o modelo europeu e a realidade brasileira precisam ser e não podem ser resolvidas provoca nas reflexões teóricas e no trabalho artístico do escritor um acirramento vertiginoso dessas antinomias.

Mário e sua obra não se furtam à intensificação desses conflitos. Ao contrário, assumindo-os, procuram levá-los às suas últimas conseqüências. Por esse motivo, a “exasperação" das contradições que não encontram sua síntese levou Mário de Andrade a formulações ao mesmo tempo radicais e desesperadas, como se a poesia, para ser socialmente verdadeira, tivesse de mentir a si mesma: "Ou a Poesia se traia inteiramente e vire cantadora pragmática dos interesses sociais, ou vire, no máximo orgulho, inexoravelmente senhoril" ${ }^{219}$; ou como se a verdade do sujeito implicasse a mentira social e a verdade social, a mentira do sujeito: "Ou o compositor faz música nacional e falsifica ou abandona a força expressiva que possui, ou aceita esta e abandona a característica nacional" ${ }^{\prime 220}$. Ou isso/ou aquilo, em suma, segundo a fórmula do conhecido livro de Kierkegaard, o filósofo do desespero e da angústia, de cujo pensamento o sacrifício é uma categoria central221.

Como se verá, os antagonismos desatados que constituem o quadro conceitual de exprimem uma espécie particular de radicalização da "alternância entre dois pólos

\footnotetext{
${ }^{219}$ Andrade, Mário de. “A poesia em 1930”, in Aspectos da literatura brasileira, op. cit., p. 52.

${ }^{220}$ Andrade, Mário de. Ensaio sobre a música brasileira, Belo Horizonte: Itatiaia, 2006, p. 31.

221 A menção a Kierkegaard, é claro, não passa, aqui, de uma lembrança. De todo modo, não custa notar que a alternativa kierkegaardiana em Ou isso/ou aquilo é a alternativa entre o estético e o ético, tendo o religioso como possibilidade de superação, um "esquema" que se aproxima sugestivamente das reflexões marioandradinas. Kierkegaard, Søren. Either/Or - A fragment of life, Londres: Penguin, 1992. Sobre o sacrifício como categoria central da filosofia kierkegaardiana, ver Adorno, Theodor W. Kierkegaard: construction of the Aesthetic, Minneapolis: Minnesota University Press, 1999, pp. 106-122.
} 
antinômicos, porém indescartáveis", própria da experiência intelectual brasileira ${ }^{222}$. Com efeito, nesses antagonismos encontra-se o dinamismo agonístico que José Antonio Pasta Júnior definiu como luta de morte, uma estrutura que o crítico tem demonstrado ser recorrente nas obras canônicas da literatura brasileira, tendo-lhe exposto o conceito e o funcionamento ao estudar $O$ Ateneu, de Raul Pompéia ${ }^{223}$. Segundo Pasta Júnior, no regime da luta de morte entre dois oponentes, "a presença de um é a ausência do outro e vice-versa; [...] cada um tem, como condição de presença, a desaparição do outro"224. Por essa razão, "a luta de morte - o nome já diz - só se pode terminar com a aniquilação de um dos contendores"225. Para quem deseja a síntese entre os antagonistas, portanto, ou seja, para quem as duas posições em conflito são irrenunciáveis, a luta de morte "é propriamente interminável" e configura uma "má-infinidade agônica", que tende, por essa razão, à exacerbação do conflito ${ }^{226}$. Como no caso de Raul Pompéia, nas reflexões e na obra literária de Mário de Andrade "a realidade é concebida sob o signo da luta de morte, ou seja, enquanto sacudida entre perspectivas que se contrapõem, negam e destroem, convulsionando-se num combate sem fim"227.

A coexistência da exigência e da impossibilidade de superação das contradições conduz o pensamento e as obras de Mário de Andrade, em especial a sua poesia, a estágios de paroxismo dramático que não se encontram nas obras de outros escritores modernistas brasileiros - a desmedida, inclusive, é um dado essencial da linguagem marioandradina e se manifesta, por exemplo, no emprego particularmente freqüente do superlativo pelo autor do "Prefácio Interessantíssimo", onde Mário escreve: "Que Arte não seja porém limpar versos de exageros coloridos. Exagero: símbolo sempre novo da

\footnotetext{
${ }^{222}$ Arantes, Paulo Eduardo. Sentimento da dialética na experiência intelectual brasileira, op. cit., p. 44.

223 Pasta Júnior, José Antonio. Pompéia: a metafísica ruinosa d’O Ateneu, op. cit., em especial as pp. 142-153 e 161-168. Ver também, do Autor, "O romance do Rosa - temas do Grande Sertão e do Brasil", in Novos Estudos CEBRAP, n55, op. cit., pp. 61-70.

${ }^{224}$ Pasta Júnior, José Antonio. Pompéia: a metafísica ruinosa d’O Ateneu, op. cit., p. 61.

225 Idem. Ibidem, p. 142.

${ }^{226}$ Idem. Ibidem, p. 143.

${ }^{227}$ Idem. Ibidem, p. 152.
} 
vida como do sonho. Por ele vida e sonho se irmanam"228. É no momento paroxístico em que a experiência das contradições atinge a sua máxima violência que se opera, em virtude da falta de mediações que permitissem a realização de uma síntese superior, a solução extrema: o sacrifício.

*** O círculo vicioso da solução sacrificial

Dilacerado entre polaridades irredutíveis, dilaceramento que resulta, justamente, do esforço exaustivo para dialetizar essas oposições, Mário de Andrade, em um lance supremo, recorre à solução sacrificial, que é a solução paradoxal da luta de morte, de acordo com Pasta Júnior: sem a mediação que possibilitaria articular dialeticamente o mesmo e o outro que se contrapõem, e diante do imperativo de resolver a contradição, o mesmo é levado a ser imediatamente o outro, o que implica a passagem do ser para o não-ser ${ }^{22}$. Por meio do sacrifício marioandradino, finalmente a arte se torna o social, o sujeito se torna o coletivo, o universal se torna o local, contudo às custas do artístico e da própria subjetividade: as contradições se resolvem, mas apenas por meio da morte ${ }^{230}$.

Sendo essencialmente mortal, contudo, a síntese obtida por meio do sacrifício não é autêntica nem estável, mas negativa e evanescente. Em virtude da ausência de dialética do geral e do particular na identificação, que se opera por meio do sacrifício marioandradino, entre o individual e o coletivo, o particular passa inteiramente na totalidade 231 . Noutros termos, a subjetividade, por intermédio de sua própria extinção, para a ser a coletividade: "eu sou tão não-eu, tão os outros", escreveu Mário, em carta

\footnotetext{
${ }^{228}$ Andrade, Mário de. Paulicéia desvairada, in Poesias completas, op. cit., p. 63.

229 Pasta Júnior, José Antonio. Op. cit., pp. 152-156.

${ }^{230}$ A solução sacrificial, conforme demonstrou Pasta Júnior, é também a solução de Macunaíma, o herói de nossa gente: "Herói brasileiro, ele foi ainda uma vez e não a última - chamado a realizar o impossível - fazer com que o movimento seja a imobilidade, o mesmo, o outro e o ser, o não-ser. Ele o fez - como de rigor - pela auto-imolação sacrificial". Pasta Júnior, José Antonio. "Tristes estrelas da Ursa Macunaíma", in Cadernos Porto\&Virgula, op. cit., p. 32.

${ }^{231}$ Um bom exemplo da falta de dialética entre o particular e o geral em muitos momentos do pensamento estético de Mário de Andrade encontra-se em uma carta do escritor a Drummond: "Hoje eu quero gritar de tal forma que meu grito seja o de toda gente. Quero dizer, tornar o menos pessoal possível minhas coisas pra que se tornem gerais". Andrade, Mário de. A lição do amigo, op. cit., p. 96.
} 
de 1925 a Drummond ${ }^{232}$. Por volta de um mês depois, Manuel Bandeira disse a Oswald de Andrade: "Você sente e critica deliciosamente o Brasil, mas não é Brasil; quem é Brasil é o Mário"’233.

A negação absoluta e sem mediação do individual consiste ao mesmo tempo, contudo, na expansão desmedida, na afirmação igualmente absoluta e imediata do indivíduo ${ }^{234}$. Noutros termos, justamente por ser imediata e abstratamente ${ }^{235}$ identificada à subjetividade que nela se aniquila, a própria coletividade, no e pelo mesmo processo identificatório, é aniquilada pela subjetividade 236: "Brasil/Como será o Brasil?/MÁRIO DE ANDRADE”, dizem os versos de Manuel Bandeira237. Essa aniquilação recíproca, cujos efeitos a organização ritualística do sacrifício procura evitar, participa da própria lógica sacrificial. Conforme notaram Hubert e Mauss, autores da melhor teoria do sacrifício de que se dispõe, todo sacrificante, isto é, o beneficiário do sacrifício, sacrifica a si mesmo na vítima: "Não basta dizer que a vítima representa o sacrificante; confunde-se com ele. As duas personalidades fundem-se"238. Ao anular-se no outro, Mário de Andrade anula o outro no e pelo mesmo movimento: "És uma propriedade minha. És uma fazenda que eu comprei. Comprei com minha alma”, escreveu Mário, comentando o início de sua longa amizade com Bandeira ${ }^{239}$.

\footnotetext{
${ }^{232}$ Idem. Ibidem, p. 40.

${ }^{233}$ Andrade, Mário de. Correspondência - Mário de Andrade \& Manuel Bandeira, op. cit., p. 241.

${ }^{234}$ Hegel formulou um impasse semelhante: "O ser do finito é o ser do infinito. [...] Ora, é preciso notar que nessa proposição a mediação entre o ser do finito e o ser do infinito não aparece. Trata-se de uma proposição sem mediação, precisamente o contrário do que se demanda [para a obtenção de uma síntese religiosa superior]. O defeito dessa formulação está em que nela se exprime o finito como afirmativo". Hegel, G. W. F., Leçons sur la philosophie de la religion, II, 1, Paris: Vrin, 1972, p. 46.
}

235 “Uma das maiores conquistas filosóficas do método dialético - já em Hegel - é o ter revelado a conexão interna entre imediatidade e abstração e ter demonstrado que, com base na imediatidade, só pode surgir um pensamento abstrato". Lukács, Georg. "Trata-se do realismo!”, in Machado, Carlos Eduardo Jordão. Op. cit., p. 207. Ver Hegel, G. W. F. Fenomenologia do Espírito,op. cit., pp. 25-95.

236 “O sacrifício não salva, por uma restituição substitutiva, a comunicação imediata apenas interrompida que os mitólogos de hoje lhe atribuem, mas, ao contrário, a instituição do sacrifício é ela própria a marca de uma catástrofe histórica, um ato de violência que atinge os homens e a natureza igualmente". Adorno, Theodor W; Horkheimer, Max. Dialética do Esclarecimento, op. cit., p. 59.

237 Bandeira, Manuel. "Variações sobre o nome de Mário de Andrade", in Poesia completa e prosa (organizada pelo autor), Rio de Janeiro: Aguilar, 1996, p. 390.

238 Hubert, Henri; Mauss, Marcel. "Ensaio sobre a natureza e a função do sacrifício”, in Mauss, Marcel. Ensaios de sociologia, São Paulo: Perspectiva, 2005, p. 170.

${ }^{239}$ Andrade, Mário de. Correspondência - Mário de Andrade \& Manuel Bandeira, op. cit., p. 92. 
O sacrifício produz, portanto, uma síntese que se desfaz ao se constituir, de tal maneira que a oposição entre o mesmo e o outro, ou entre o individual e o coletivo, é reposta no ato mesmo por meio do qual é eliminada: "Eis que chego a esse paradoxo irrespirável: tendo deformado toda a minha obra por um anti-individualismo dirigido e voluntarioso, toda a minha obra não é mais que um hiper-individualismo implacável!"240. Em outras palavras, ao sacrificar a sua arte e a si mesmo pelo social, Mário de Andrade sacrifica o próprio social. A partir do final dos anos 1930, Mário passou a notar, por exemplo, que sua tentativa de estilização culta da fala brasileira - o maior de seus sacrifícios, segundo Manuel Bandeira ${ }^{241}$ - paradoxalmente resultara na criação de uma língua pessoal. Sobre Macunaíma, por exemplo, disse o escritor, em entrevista de 1944, um ano antes de sua morte: "Quis escrever um livro em todos os linguajares regionais do Brasil. O resultado foi que, como já disseram, me fiz incompreensível até para os brasileiros" ${ }^{242}$. Mário talvez se referisse, nesse trecho, à dura crítica que lhe foi feita por Manuel Bandeira acerca dos "exageros nativistas" praticados pelo autor de Macunaíma na realização de seu projeto de abrasileirar a linguagem escrita no país: "Sua nobre tentativa de linguagem brasileira, feita no pensamento de nos unir mais os brasileiros, idéia portanto altamente socializante, se tem afirmado dessocializante: a maioria das pessoas simples que lêem você sentem dificuldade de compreendê-lo. Quando você escreve 'sube' e 'intaliano', ninguém sente o seu desejo de comunhão nem o seu sacrifício, mas a sua personalidade indiscreta $e$ tirânica querendo impor na linguagem literária escrita formas da linguagem popular ou culta falada que agradam à sua sensibilidade de grande escritor’’243.

\footnotetext{
${ }^{240}$ Andrade, Mário de. "O movimento modernista", in Aspectos da literatura brasileira, op. cit., p. 279.

${ }^{241}$ Bandeira, Manuel. Apresentação da poesia brasileira, São Paulo: CosacNaify, 2009, pp. 157-158.

${ }^{242}$ Em entrevista de 1944 a Francisco de Assis Barbosa. Andrade, Mário de. Entrevistas e depoimentos, op. cit., p. 105.

243 Andrade, Mário de. Correspondência - Mário de Andrade \& Manuel Bandeira, op. cit., p. 516. Roberto Schwarz faz uma observação semelhante: "Nada mais pessoal e intransferível que a fisionomia dessa escrita que se queria funcional, como que indicando que seu gigantismo não era repetível. Com efeito, hoje ela se lê como uma extraordinária façanha de expressão individual, associada ao desejo de aperfeiçoar a nacionalidade". Schwarz, Roberto. "Outra Capitu", in Duas meninas, São Paulo: Companhia das Letras, 1997, p. 142.
} 
Com efeito, o sacrifício, conforme notaram Adorno e Horkheimer, consiste em grande medida em um logro, em uma fraude, por meio da qual o indivíduo "se perde $a$ fim de se ganhar"244, “"perece' para se tornar 'ele mesmo"”245, uma estratégia ruinosa que é também a do masoquista, que afirma o eu por meio de sua própria extinção, glorifica-o por intermédio de sua própria humilhação ${ }^{246}$. No ato sacrificial, algo vem a ser ao ser destruído ${ }^{247}$, vem a ser, em suma, deixando de ser - como Macunaíma, conforme notou José Antonio Pasta Júnior: “ele vem a ser no e pelo ato mesmo de sua

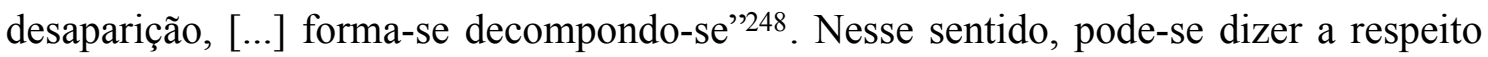
do sacrifício o que Mário de Andrade afirmou sobre seu herói, ou seja, que ele "é uma contradição de si mesmo"249.

Essa contradição imanente ao sacrifício - "o caráter paradoxal do sacrifício", escreveu Adorno ${ }^{250}$ - instaura, no caso de Mário, um círculo vicioso em que o sacrifício do particular em nome do coletivo paradoxalmente "produz" um particular ainda mais marcado e isolado que o anterior, o que exige um novo sacrifício, um sacrifício ainda maior, e assim por diante. Pode-se acompanhar esse movimento em uma importante carta escrita por Mário de Andrade no auge de sua fase nacionalista, em janeiro de 1928, a Manuel Bandeira:

"Eis a miséria: é que os poemas, estes, muito menos individualistas na forma e no pensamento geral, atingiram o máximo de individualismo, já não podem mais interessar ninguém senão eu. E fico na contradição mais amargamente irônica de minha vida. [...] Minha

\footnotetext{
${ }^{244}$ Adorno, Theodor W.; Horkheimer, Max. Dialética do Esclarecimento, op. cit., p. 56.

${ }^{245}$ Adorno, Theodor W. Kierkegaard: construction of the Aesthetic, op. cit., p. 108.

246 Reik, Theodor. Le masochisme, Paris: Payot, 2000, pp. 229-250.

${ }^{247}$ Herrenschmidt, Olivier. "A qui profite le crime? Cherchez le sacrifiant”, in op. cit., pp. 7-18.

248 Pasta Júnior, José Antonio. Op. cit., p. 28.

${ }^{249}$ Andrade, Mário de. Correspondência-Mário de Andrade \& Manuel Bandeira, op. cit., p. 368.

${ }^{250}$ Adorno, Theodor W. Op. cit., p. 114.
} 
inquietação agora atingiu uma grandeza verdadeiramente trágica e minha vida interior está transformada num delírio. [...] E o turtuveio é medonho em mim. Nunca me esforcei tanto como agora pra compreender e amar os outros. [...] Não tem mais livro que não valha nada para mim. [...] Meu único ideal é sentir e amar os homens e gozar por isso. [...] E é por esse meu estado de espírito que sou muito mais vasto que vocês" 251 .

Conforme terá notado o leitor, o trecho se inicia com a chocante constatação da contradição provocada pela solução sacrificial, ou seja, com o reconhecimento de que, por meio do sacrifício, o extremo de desinviduação resulta, paradoxalmente, no máximo de individualismo. O paradoxo do sacrifício leva o escritor a paralisar-se, perplexo, no centro da contradição, diante da duplicidade insolúvel, tomado por uma combinação de abatimento e angústia, característica da melancolia: "E fico na contradição", escreve Mário de Andrade. Com efeito, a melancolia tem algo de uma paralisia do espírito que "se perde em contradições" 252: em seu núcleo está a acedia, a inércia do coração, que amortece a alma do melancólico, do príncipe indeciso, de Hamlet absorvido pela dúvida entre o ser e o não-ser. A disposição melancólica é marcada pela ambivalência, por um dualismo intenso e fundamental. Seu movimento é o movimento imóvel da ruminação obsessiva que oscila entre opostos sob o signo de Saturno, demônio das antíteses ${ }^{253}$.

Para Freud, autor de um estudo célebre sobre o assunto, a ambivalência na qual se funda a melancolia é a ambivalência decorrente da identificação narcísica do objeto amoroso ao $\operatorname{ego}^{254}$, ou seja, da redução do outro ao mesmo do eu, redução por meio da qual não apenas o outro é “devorado" pelo eu, mas o próprio eu se torna o outro,

\footnotetext{
${ }^{251}$ Andrade, Mário de. Op. cit., p. 377, grifo meu.

252 Klibansky, Raymond; Panofsky, Erwin; Saxl, Fritz. Saturne et la mélancolie (études historiques et philosophiques: nature, religion, médecine et art), Paris: Gallimard, 2004, pp. 76, 90.

253 Benjamin, Walter. Origem do drama barroco alemão, São Paulo: Brasiliense, 1984, pp. 161-180.

${ }^{254}$ Freud, Sigmund. "Luto e melancolia", in Revista Novos Estudos CEBRAP, $\mathrm{n}^{\circ}$ 32, São Paulo: março de 1992, pp. 128-142.
} 
perdendo-se - como se sabe, Narciso, que vive a cisão de ser outro, morre encantado com a própria imagem. $\mathrm{Na}$ origem da melancolia, portanto, está o eu que se afirma negando-se. Ora, como temos observado, a afirmação do indivíduo por intermédio de sua própria negação constitui o regime mesmo do sacrifício marioandradino. Para a análise, portanto, da dinâmica sacrificial de Mário de Andrade, na qual o individual, ao passar inteiramente no coletivo, não encontra, neste, senão a si mesmo, as idéias de Freud sobre a melancolia não deixam de ser sugestivas ${ }^{255}$, ainda que não exista, neste trabalho, a intenção de fazer psicologia do autor, muito menos de basear na teoria psicanalítica a interpretação da poesia de Mário de Andrade.

Isso posto, vale notar que, em diversas ocasiões ao longo de sua vida, Mário de Andrade foi acometido por tristezas mais que profundas. Em 1928, por exemplo, Mário noticia a Bandeira: "Ando num abatimento danado, [...] estou na mesma situação patológica em que fiquei em 1913, quando os médicos falavam pra meu pai que não davam mais nem um tostão por esta vida que inda está escrevendo pra você. Mesmos sintomas. [...] As mãos caem no chão que custa erguê-las" ${ }^{256}$. Dez anos mais tarde, escreve a Murilo Miranda: "E ando adoentado, fatigado, fatigadíssimo. Sem felicidade quase nenhuma, um corpão monótono e de enorme malinconia"257. Aproximadamente um ano depois, encontra-se em estado ainda mais opressivo: "Uma depressão nervosa total, uma angústia pavorosa que me fecha as entranhas dia e noite e me impede respirar"258. Por fim, a partir de 1938, ano de sua demissão do Departamento de Cultura, até sua morte, em 1945, Mário de Andrade seria cada vez mais tomado pela melancolia, reduzindo-se os momentos de entusiasmo, tão comuns durante a juventude do escritor. Segundo Paulo Duarte, principal companheiro de Mário nas atividades departamentais,

${ }^{255}$ Em especial, se for levado em consideração que o sacrifício de Mário de Andrade, segundo o próprio escritor, tem por base o amor, fundamento da melancolia freudiana: "A parte messiânica do meu esforço, o sacrificar minhas obras, escrevendo-as em língua que ainda não é língua, [...] é uma necessidade fatal do meu espírito e da minha maneira de amar". Ora, o amor, afirma Mário de Andrade, é essencialmente um sentimento narcisista, assim como o amor do melancólico, para Freud: "Amor, no sentido geral, [...] é uma questão de espelho. Este mundo está cheio de Narcisos". Andrade, Mário de. Correspondência Mário de Andrade \& Manuel Bandeira, op. cit., pp. 181-182. Andrade, Mário de. A lição do amigo, op. cit., p. 31.

\footnotetext{
256 Apud Andrade, Mário de. A lição do amigo, op. cit., p. 271.

${ }^{257}$ Andrade, Mário de. Cartas a Murilo Miranda (1934-1945), op. cit., p. 48.

${ }^{258}$ Apud Andrade, Mário de. A lição do amigo, op. cit., p. 276.
} 
“a expulsão de Mário de Andrade do Departamento causou-lhe um estado de choque espiritual do qual nunca mais voltaria" ${ }^{259}$. Nesse período final e dolorosíssimo, Mário chegou inclusive a sofrer de pânico e de delírios obsessivos e paranóicos ${ }^{260}$.

A essa profunda melancolia final, o escritor confere expressão inigualável na meditação sombria - a disposição melancólica é essencialmente meditativa... - que constitui seu grande poema final, "A meditação sobre o Tietê"261, em que se consuma toda a dor, toda a experiência dramática das antinomias vividas pelo escritor, drama essencialmente vinculado à impossibilidade de resolver as contradições histórico-sociais brasileiras por meio do sacrifício da própria subjetividade. Nessa trágica meditação, o leitor encontrará os signos clássicos da melancholia, a começar pelo rio noturno “Água noturna, noite líquida”262 - como a bile negra, o licor sombrio e viscoso - “Água pesada e oleosa" - que, de acordo com a antiga teoria dos humores, provoca a doença e lhe dá o nome ${ }^{263}$. Encontrará, também, os temas do espírito cansado - "As altas torres do meu coração exausto" - e do espírito cansado combinado ao delírio - "Eu me acho tão cansado em meu furor" -, a figuração de um solene e exasperante regime de recorrência - "É noite. E tudo é noite. [...] E os meus olhos são noite!" -, a tristeza absoluta e angustiada, que prenuncia catástrofes futuras ${ }^{264}$ - "Tristeza que timbra um

259 Duarte, Paulo. Mário de Andrade por ele mesmo, São Paulo: Hucitec, 1977, p. 7. Ver Andrade, Mário de. Cartas a um jovem escritor (de Mário de Andrade a Fernando Sabino), Rio de Janeiro: Record, 1981, pp. 29-30. Sobre o período final da vida de Mário de Andrade, ver Duarte, Paulo. Op. cit., pp. 123-144 e Castro, Moacir Werneck de. Mário de Andrade: exílio no Rio, op. cit., pp. 19-144.

260 Tal como relata, por exemplo, em uma impressionante carta a Drummond. Ver Andrade, Mário de. $A$ lição do amigo, op. cit., pp. 223-225.

261 José Emílio Major Neto comenta a presença da melancolia em “A meditação sobre o Tietê" em $A$ Lira Paulistana de Mário de Andrade: a insuficiencia fatal do Outro, Tese de Doutoramento em Teoria Literária e Literatura Comparada apresentada à Faculdade de Filosofia, Letras e Ciências Humanas da USP, São Paulo, 2006, pp. 214-218.

262 Andrade, Mário de. “A Meditação sobre o Tietê”, in Poesias completas, op. cit., pp. 386-396. Para evitar o acúmulo de notas de rodapé, já excessivamente numerosas, remeto desde já o leitor, no caso das próximas citações de versos da "Meditação" deste parágrafo, ao Anexo I, que se encontra no final deste trabalho.

263 "O nome é imposto pela matéria e a doença é nomeada com base em sua causa material, como observa

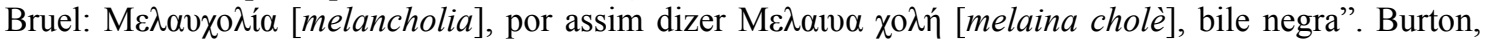
Robert. The Anatomy of Melahncoly. Oxford: Oxford University Press, 1989, p. 162. Uma seleção de escritos sobre a melancolia baseados na antiga teoria dos humores encontra-se em Dandrey, Patrick. Anthologie de l'humeur noire: écrits sur la mélancolie d'Hippocrate à l'Encyclopédie. Paris: Le Promeneur, 2005. Sobre a teoria dos humores, ver Klibansky, Raymond; Panofsky, Erwin; Saxl, Fritz. Op. cit., pp. 31-45.

264 Benjamin, Walter. Op. cit., p. 170. 
caminho de morte" -, as visões proféticas pesadelares - "Eu vejo; $[\ldots] /$ Nas tuas águas eu contemplo o Boi Paciência/Se afogando" -, a compreensão de verdades profundas ${ }^{265}$ - especificamente, a compreensão de verdades terríveis sobre o Brasil, em particular a desoladora tomada de consciência da perpetuação e do agravamento da violência e das injustiças seculares características da formação político-social brasileira: "Vai ficar tudo na mesma, mas vai!” -, a auto-recriminação e a auto-degradação 266 - “Tu és demagogia. A própria vida abstrata tem vergonha/de ti" -, o ser pensante em perplexidade 267 - "Meu pensamento quer pensar, [...] mas tudo se desfaz num choro de agonia" -, o desespero que se avizinha da loucura - "Rio, o que eu posso fazer!" -, o pânico de uma desgraça indefinida - "Eu tenho medo... meu coração está pequeno" -, os surtos delirantes ${ }^{268}$, que são também delírios formais, lingüísticos - "E os Prados e os crespos e os pratos e os barbas e os gatos e os línguas" - e, finalmente, o pensamento sobre a morte, no qual a melancolia se aproxima da reflexão lutuosa, com a peculiaridade de que a melancolia é um tipo singular de luto por si mesmo - "E fui por tuas águas levado/ A me reconciliar com a dor humana pertinaz".

Em especial, todavia, o leitor encontrará, em "A meditação sobre o Tietê", uma característica central da disposição melancólica, que resulta da combinação de todas as anteriores e que se relaciona diretamente com a noção de sacrifício: a tendência ao suicídio $^{269}$ - "Eu sigo alga escusa nas águas do meu Tietê" -, de maneira que o poema

\footnotetext{
265 Aristóteles, no conhecido "Problema XXX, 1", estabelece uma relação entre a melancolia e os "homens excepcionais": "Por que razão todos os que foram homens excepcionais no que concerne à filosofia, à ciência do Estado, à poesia ou às artes, são manifestamente melancólicos?". Aristóteles. L'Homme de génie et la Mélancolie, Paris: Rivages, 1988, p. 83. Ver também Benjamin, Walter. Op. cit., pp. 174-176.

${ }^{266}$ Freud, Sigmund. Ibidem.

267 Matos, Olgária. Ibidem, p. 169.

268 "Porque a bile negra é inconstante, inconstantes são os melancólicos". Aristóteles. Op. cit., p. 107. Vale notar que Aristóteles aproxima os efeitos da bile negra aos efeitos do vinho, assemelhando o estado de espírito melancólico à embriaguez dionisíaca, também familiar a Mário de Andrade. A caracterização da melancolia como um estado de espírito marcado pela inconstância também se encontra em Freud: "A peculiaridade mais notável da melancolia, a que mais requer esclarecimento é sua tendência a se transformar no estado sintomaticamente oposto da mania”. Freud, Sigmund. Ibidem, p. 137.

269 "É aqui, particularmente, onde se verifica o caráter enigmático da melancolia: na forma em que a vida se alça contra si mesma. [...] Manifesta-se [na melancolia] uma tendência a arrebatar à vida do indivíduo a possibilidade de existir, a sacudir os pontos de apoio que sustentam o sujeito, a questionar os valores que justificam a própria vida, de tal modo que o indivíduo, ao alcançar esse estado de espírito em que não vê justificação alguma à própria existência, sente-se suspendido no vazio e no absurdo, ou seja, é levado ao desespero". Guardini, Romano. De la mélancolie, Paris: Seuil, 2000. Ver também, sobre a tendência da melancolia ao suicídio, Freud, Sigmund. Op. cit., p. 137.
} 
se constitui, entre outras coisas, como um presságio, uma antecipação da morte de seu próprio autor - Mário de Andrade, como se sabe, morreu apenas duas semanas depois de concluir a "Meditação"270. Há algo de um Abschied, característico de obras tardias"271, na "Meditação sobre o Tietê", como se Mário de Andrade repassasse, por uma última vez, sua vida inteira, seus sonhos e frustrações, todos os seus dramas ${ }^{272}$, como forma de se despedir de si mesmo, de sua cidade e de seu país, para em seguida, em um gesto cheio de ressonâncias sacrificiais, encomendar-se à própria morte:

"Eu me reverto às tuas águas espessas de infâmias, Oleosas, eu, voluntariamente, sofregamente, sujado De infâmias, egoísmos e traições." 273

Note-se a natureza romântica desse movimento de auto-extinção, no qual "a morte é o livrar-se de um tormento, um abandono de si mesmo porque não se pode mais suportar a injustiça da vida", como escreveu Adorno sobre Schumann ${ }^{274}$. Com efeito, de acordo com a filosofia hegeliana, o sacrifício, em seu modelo cristão, participa da essência do romantismo: "A dor infinita que acompanha o sacrifício da subjetividade, o sofrimento e a morte que estavam mais ou menos eliminados nas representações da arte clássica, somente na arte romântica adquirem um caráter de necessidade"275. Assim, de

\footnotetext{
270 Mário também parece pressentir a própria morte em uma carta impressionante, escrita dez dias antes de sua morte a Paulo Duarte: "Eu tenho apenas um medo vago, mas nitidíssimo de que alguma coisa vá morrer". Duarte, Paulo. Op. cit., p. 282.

271 Adorno, Theodor W., Mahler, une physionomie musicale, Paris: Les Éditions de Minuit, 1996, pp. 211-244.

272 "Levados pela água barrenta do rio, vão passando os temas e as constantes da sua poesia, os 'sinais', as velhas angústias, misturadas às angústias novas". Candido, Antonio. "Mário de Andrade", in Revista do Arquivo Municipal, CVI, São Paulo: jan/fev de 1946, p. 73.
}

${ }^{273}$ Andrade, Mário de. Op. cit., p. 387.

274 Adorno, Theodor W. Beethoven: The Philosophy of Music (fragments and texts edited by Rolf Tiedemann), Stanford: Stanford University Press, 1998, p. 155. Em carta de outubro de 1925, Manuel Bandeira escreveu a Mário: "Você tem fundo romântico". No ensaio "Permanência e mudança na poesia de Mário de Andrade", Luiz Costa Lima, com base em uma série de preconceitos estéticos, defende a tese de que a poesia de Mário de Andrade fracassa por não conseguir libertar-se do subjetivismo romântico. Andrade, Mário de. Correspondência - Mário de Andrade \& Manuel Bandeira, op. cit., p. 247. Lima, Luiz Costa. Lira e antilira, Rio de Janeiro: Topbooks, 1995, pp. 47-128.

275 Hegel, G. W. F. Curso de Estética: o Belo na Arte, São Paulo: Martins Fontes, 1996, p. 575. Sobre a relação entre o sacrifício e a arte romântica, ver pp. 569-605. 
acordo com Hegel, a conciliação do espírito consigo mesmo, princípio básico da arte romântica, manifesta-se pela primeira vez na história da Paixão e da redenção de Cristo. O espírito que anseia, consciente de sua infinitude, unir-se absolutamente a sua própria essência, a subjetividade espiritual que não aceita senão o lhe é intrínseco, que se quer portanto infinita, assume uma atitude negativa em relação a sua existência exterior, ou seja, à corporeidade e à finitude. Por meio da negação do sensível, o espírito afirma sua liberdade e seu triunfo. Por essa razão, a expressão do conteúdo substancial da arte romântica - a expressão, pois, da subjetividade absoluta - assume, em primeiro lugar, a forma do martírio: "No homem que ainda não desenvolveu toda a sua interioridade, a primeira coisa que tem de ser separada deste mundo e santificada é a sua existência natural, a sua vida, a satisfação de suas exigências mais urgentes e mais vitais. [...] O meio que permite atingir esse fim consiste em suportar estoicamente os sofrimentos mais cruéis, em impor-se todas as renúncias, todos os sacrifícios, privações, em infligirse, portanto, dores, martírios, torturas, a fim de em si assegurar o triunfo do espírito"276.

No romantismo, a morte liberta o espírito da naturalidade pura e simples e da finitude incompatível com o conceito deste, proporcionando, ao espírito reconciliado, a pacificação resultante de encontrar em si mesmo uma existência concordante com a sua natureza ${ }^{277}$. No poema final de Mário de Andrade, contudo, não se encontra sinal da ultrapassagem do sofrimento, da conciliação afirmativa que se segue à negatividade da mortificação e que constitui a última e gloriosa etapa do martírio romântico. Em "A meditação sobre o Tietê", a morte não pacifica a alma, o sacrifício não liberta o sujeito de seu tormento, portanto não abole a dor e não faz cessar o desespero. As águas do rio "são malditas e dão morte"278, mas impedem, ao mesmo tempo, a morte definitiva, redentora:

"Sarcástico rio que contradizes o curso das águas

E te afastas do mar e te adentras na terra dos homens,

\footnotetext{
${ }^{276}$ Idem. Ibidem, p. 599.

${ }^{277}$ Idem. Ibidem, p. 576,

${ }^{278}$ Andrade, Mário de. Op. cit., p. 388.
} 
Onde me queres levar?...

Por que me proíbes assim praias e mar, por que

Me impedes a fama das tempestades do Atlântico

E os lindos versos que falam em partir e nunca mais voltar?

Rio que fazes terra, húmus da terra, bicho da terra,

Me induzindo com a tua insistência turrona paulista

Para as tempestades humanas da vida, rio, meu rio!..." 279

Perder-se no rio não leva ao "doce enlanguescer de quem não tem mais nada a perder", à "ternura de uma consolação ambígua" proporcionada pela morte 280 , mas, ao contrário, reconduz às mesmas contradições a que o sacrifício supremo esperava dar solução. Desse modo, "A meditação sobre o Tietê" é uma imagem eloqüente das aporias do sacrifício marioandradino, da má-infinidade que a auto-imolação do sujeito não interrompe e renova. Ao reverter, devastado por antagonismos insuperáveis, às águas envenenadas do rio, o poeta não põe termo a seu drama, mas oferece o próprio corpo para ser, outra vez, dilacerado pelas contradições que não suporta mais. Nesse sentido, o final da "Meditação", que marca o fim da obra poética de Mário de Andrade, tem algo de um ruinoso "mais, ainda". O poema termina, em suma, sem terminar, reiniciando o ciclo sacrificial.

Passemos, então, à segunda parte da carta escrita por Mário de Andrade a Manuel Bandeira em janeiro de 1928, por meio da qual é possível acompanhar o círculo vicioso da "solução" sacrificial dada pelo escritor às oposições - que rasgam seu pensamento estético - entre o artista e a sociedade, entre a literatura e a práxis. Conforme visto, após constatar que seu projeto literário anti-individualista havia paradoxalmente resultado em uma literatura ultra-individualista, Mário de Andrade paralisa-se em face do contra-senso: "E fico na contradição mais amargamente irônica

\footnotetext{
${ }^{279}$ Idem. Ibidem, p. 387.

280 As expressões citadas são de Adorno, e são empregadas pelo Autor ao estudar o "longo olhar" de despedida que as obras tardias de Mahler lançam sobre o mundo e sobre a vida. Adorno, Theodor W., Mahler, une physionomie musicale, op. cit., pp. 224, 227.
} 
de minha vida". A impossibilidade de superação do antagonismo entre o estético e o social por intermédio do sacrifício da obra de arte, associada à necessidade imperiosa de resolvê-lo, conduz à exasperação do conflito, o que pode levar à loucura o eu que o assume em toda a linha. $\mathrm{Na}$ carta a Bandeira, é justamente ao delírio que o paradoxo do sacrifício, agravando-se, leva Mário de Andrade: "Minha inquietação agora atingiu uma grandeza verdadeiramente trágica e minha vida interior está transformada num delírio. [...] E o turtuveio é medonho em mim".

A caracterização, por Mário de Andrade, de sua situação como sendo trágica é absolutamente pertinente, pelo menos se o conceito de trágico for compreendido de acordo com as definições semelhantes e complementares que lhe deram pensadores tão diferentes como Goethe e Kierkegaard. Em uma de suas Conversações com Eckermann, o escritor alemão expôs as condições objetivas do trágico nos seguintes termos: "Todo o trágico se baseia em uma contradição inconciliável. Tão logo aparece ou se torna possível uma acomodação, desaparece o trágico"281. Em sentido análogo, Kierkegaard especificou o sentimento próprio da experiência trágica - o desespero: "O trágico é a contradição sofredora. [...] A perspectiva trágica vê a contradição e desespera da saída" ${ }^{282}$. Essa impossibilidade de superação da condição trágica foi notada pelo próprio Mário de Andrade: "No conceito mesmo do trágico, está implícita a impossibilidade da vitória futura'"283. Mais do que apropriada, contudo, a menção de Mário à natureza trágica de sua situação é sugestiva, não apenas porque ao trágico são tradicionalmente associadas as idéias de auto-aniquilamento e de sacrifício ${ }^{284}$, mas na medida em que sugere, também, que a extrema dificuldade, encontrada pelo escritor, de superar as contradições entre o individual e o coletivo por meio da literatura deve-se menos a

\footnotetext{
281 Apud Szondi, Peter. Ensaio sobre o Trágico, Rio de Janeiro: Jorge Zahar, 2004, p. 48. Três anos depois, Goethe diria a Eckermann que o conflito trágico "não permite qualquer solução". Observe-se que Goethe considerava o trágico estranho a sua natureza: "Não nasci para ser poeta trágico, já que tenho uma natureza conciliadora", escreveu. Goethe, Johann Wolfgang von. Conversations avec Eckermann, Paris: Gallimard, 2001, pp. 380-412.

282 Apud Szondi, Peter. Op. cit., p. 59.

${ }^{283}$ Andrade, Mário de. “A volta do condor”, in Aspectos da literatura brasileira, op. cit., p. 174.

284 “O genuíno herói trágico sacrifica a si mesmo e tudo o que tem pelo universal”. Kierkegaard, Søren. Fear and Trembling, Londres: Penguin, 2003, p. 137.
} 
qualidades subjetivas do que a condições objetivas - no caso, de natureza históricosocial -, que ultrapassam o indivíduo. De fato, apesar de recorrer a medidas extremas, entre as quais a mais radical é certamente o sacrifício, Mário não consegue libertar-se de uma dinâmica propriamente enlouquecedora, que temos observado: o sujeito, no esforço máximo de converter-se no coletivo, ou seja, por meio da aniquilação de si mesmo, reencontra apenas, ao final dessa conversão suprema, a si próprio. Trata-se, portanto, de uma espécie de movimento sem resultado, pois que regido por uma lógica desesperadora em que a transformação é, ao mesmo tempo, a reiteração.

Em seu movimento reiterativo e catastrófico, o sacrifício de Mário de Andrade repete em sua esfera própria um processo histórico-social em que as mesmas contradições são repostas a cada avanço aparente.

Afinal, o regime da mudança como permanência está na base da modernização conservadora, ritmo fundamental, como se sabe, da formação histórica brasileira ${ }^{285}$, do qual a emancipação política do país é o momento inaugural e paradigmático ${ }^{286}$, mas de que a Revolução de 1930 constitui, provavelmente, seu exemplo mais preciso, pois que nela é que se trata, pela primeira vez no Brasil, a rigor, da inauguração de um processo de modernização. Este, contudo, não se deu mediante a ruptura com o "antigo regime". Ao contrário, realizou-se por meio da renovação da "dupla articulação" que marca a economia brasileira desde a Independência ou antes: no âmbito interno, a articulação do setor "moderno" ao setor arcaico; no âmbito externo, a articulação da economia local à expansão do capitalismo central, portanto a renovação da condição periférica do país, que permitia às nossas classes dominantes usufruir das vantagens do desenvolvimento econômico capitalista sem pagar o preço de uma revolução burguesa clássica ${ }^{287}$. Somese a isso a manutenção da exclusão política das classes populares sob o discurso do fim da concentração do poder no país, a preservação de estruturas "primitivas" de produção

\footnotetext{
285 Pasta Júnior, José Antonio; Penjon, Jacqueline. "Le rythme singulier d'une formation historique", in Littérature et modernisation au Brésil, Paris: Presses Sorbonne Nouvelle, 2004, pp. 6-12.

286 Novais, Fernando. Portugal e Brasil na crise do Antigo Sistema Colonial (1777-1808), São Paulo: Hucitec, 1995. Idem. "Passagens para o Novo Mundo", in Aproximações, São Paulo: Cosac Naify, 2005, pp. 183-194. Alencastro, Luiz Felipe de. "La traite négrière et l'unité nationale brésilienne", in Revue Française d'Histoire d'Outre-Mer, LXVI, 1979, no 244-245.
}

${ }^{287}$ Fernandes, Florestan. A revolução burguesa no Brasil, op. cit., pp. 280-325. 
no campo e a organização, sob a aparência de uma redefinição moderna das formas de exploração do trabalho, de uma legislação trabalhista que garantia a recriação ampliada dos modos arcaicos de acumulação capitalista, próprios do Brasil escravista, e teremos a imagem resumida de um processo de modernização conservadora total, que abrange, no campo como nas cidades, as esferas econômica, social e política do país ${ }^{288}$.

Historicamente, o movimento que levou Getúlio Vargas ao poder divide ao meio a produção poética marioandradina, que se inicia em torno de 1913 e se encerra em $1945^{289}$. Nesse sentido, pode-se dizer que a Revolução de 1930 , que prometia a extinção do nosso "antigo regime" e a superação da herança colonial, mas que não cumpriu nenhuma das duas coisas, constitui uma espécie de eixo em torno do qual se organiza a lírica de Mário de Andrade. Tomada em seu conjunto, a obra literária do autor de Caféprojeto de ópera que representa, impregnado de pathos trágico e de utopia, a revolução que 1930 ficou devendo ${ }^{290}$ - desenvolve-se sob o signo desse movimento histórico decepcionante, por que Mário de Andrade inicialmente se entusiasmou e com o qual, em pouco tempo, se decepcionou profundamente.

Foi a Revolução de 1930, com efeito, que permitiu ao escritor vislumbrar com animada confiança, particularmente em virtude da organização do Departamento de Cultura de São Paulo, a realização do objetivo que norteou sua atividade intelectual: a generalização e a conseqüente "tradicionalização" da cultura no Brasil. Foi justamente, contudo, o fato que consolidou a natureza regressiva do movimento "revolucionário", ou seja, o golpe de Estado de 1937, que destroçou as esperanças do escritor em relação às possibilidades de uma formação cultural brasileira - o que significava, para Mário de Andrade, que uma formação social também passava a estar fora do horizonte no Brasil. Nesse ponto, o escritor modernista reatualizava o vínculo, que remonta aos românticos e

\footnotetext{
288 Oliveira, Francisco de. Crítica à razão dualista/O ornitorrinco, São Paulo: Boitempo, 2003, pp. 25-69, 125-132. Fausto, Boris. A Revolução de 1930: historiografia e história, São Paulo: Brasiliense, 1976.

289 Ver "Poemas anteriores a 1917", in Alvarenga, Oneyda. Mário de Andrade, um pouco, op. cit., pp. 115-125. Desconsidero, nessa periodização elementar, os poemas escritos por Mário antes de 1913, tendo em vista que ele não os conservou, com a exceção do conhecido "Poema escrito aos dez anos", e que não constituem o início de uma atividade poética ininterrupta, ou de uma formação poética.

${ }^{290}$ Em carta a Paulo Duarte, por exemplo, Mário de Andrade define a situação do povo no Café, antes da conflagração do movimento revolucionário, como sendo "tragiquíssima". Duarte, Paulo. Op. cit., p. 256.
} 
passa por Sílvio Romero, entre o ideal de constituição de uma vida cultural brasileira orgânica e a estruturação sociopolítica do país ${ }^{291}$.

Assumindo integralmente, pois, as contradições centrais da nação marcada pelo regime histórico infernal, pois que dele não parece haver remissão, da ultrapassagem que não supera, Mário de Andrade padeceu, ao longo de sua vida, sofrimentos morais e físicos atrozes ${ }^{292}$, para os quais, quando estes alcançavam seu paroxismo, o escritor não pôde encontrar senão soluções de caráter sacrificial. Conforme dito, porém, o sacrifício não resolve as contradições que por seu intermédio se espera resolver, mas, ao contrário, as repõe e intensifica.

$\mathrm{Na}$ importante carta a Bandeira que estamos comentando, por meio da qual se pode acompanhar o círculo vicioso do sacrifício marioandradino, vimos, justamente, Mário de Andrade constatar, com muita angústia, que o sacrifício do individualismo em sua poesia resultara em uma poesia ainda mais individualista, portanto ainda menos social, de acordo com o pensamento estético do escritor. Vimos, também, que o paradoxo da solução sacrificial marioandradina, solução que agrava a contradição entre a arte e a sociedade no movimento mesmo pelo qual pretende superá-la, constituindo algo como um beco-sem-saída literário, leva o escritor, pois que este não renuncia ao conflito, quase à loucura. Com perdão da repetição, que creio necessária: "Minha inquietação agora atingiu uma grandeza verdadeiramente trágica e minha vida interior está transformada num delírio. [...] E o turtuveio é medonho em mim”. Nessa espécie de auge do sofrimento, quando a contradição se torna propriamente intolerável e a consciência ameaça soverter-se na loucura, Mário de Andrade, para resolver a antinomia insolúvel, recorre a um novo sacrifício, em maior escala. Assim, após relatar o delírio que dele se apoderou, Mário diz a Bandeira: "Nunca me esforcei tanto como agora pra

\footnotetext{
291 Arantes, Paulo Eduardo. "Providências de um crítico literário na periferia do capitalismo", in Arantes, Otília Beatriz Fiori; Arantes, Paulo Eduardo. Sentido da formação: três estudos sobre Antonio Candido, Gilda de Mello e Souza e Lúcio Costa, São Paulo, Paz e Terra, 1997, pp. 11-19.

292 Em 1926, o autor da "Cantiga do Ai” já afirmava a Manuel Bandeira: "O que posso garantir pra você é que foi enorme o que eu sofri”. No mesmo sentido, em 1944, Mário escreveu a Newton Freitas: "Lhe mando o meu retrato que mais gosto [...]. Gosto mais porque marca no meu rosto os caminhos do sofrimento". Ver Andrade, Mário de. Correspondência - Mário de Andrade \& Manuel Bandeira, op. cit., 321 e Idem. A lição do amigo, p. 39.
} 
compreender e amar os outros. [...] Não tem mais livro que não valha nada para mim. [...] Meu único ideal é sentir e amar os homens e gozar por isso"293.

O leitor terá sentido o travo cristão das palavras de Mário, nas quais subjaz, sob a forma de uma profissão de fé do amor universal pela humanidade, o ideal de uma santa abnegação. Para Mário de Andrade, com efeito, a noção de sacrifício funda-se na combinação de amor e renúncia, própria da santidade, assumindo o caráter, desse modo, de um anseio de um doce martírio, anseio que se exprime com nitidez nas primeiras estrofes do poema "Aspiração", nas quais é associado à imagem sacrificial do poeta que "se dissolve" no outro, tão freqüente na lírica marioandradina:

"Doçura da pobreza assim...

Perder tudo o que é seu, até o egoísmo de ser seu,

Tão pobre que possa apenas concorrer pra multidão...

Dei tudo o que era meu, me gastei no meu ser,

Fiquei apenas com o que tem de toda gente em mim...

Nem me sinto mais só, dissolvido nos homens iguais!

Eu caminhei. Ao longo do caminho,

Ficava no chão orvalhado da aurora,

A marca emproada dos meus passos.

Depois o Sol subiu, o calor vibrou no ar

Em partículas de luz doirando e sopro quente.” 294

Como se sabe, no ciclo de cultura a que pertence o Autor, o modelo mais recuado de assunção da pobreza por amor incondicional aos homens é ninguém menos que o próprio Cristo. O ideal da imitatio Christi, ou da imitação da vítima sacrificial

\footnotetext{
293 Andrade, Mário de. Correspondência - Mário de Andrade \& Manuel Bandeira, op. cit., p. 368. Ver, também, supra, p. 20.

294 O poema é de 1924. Andrade, Mário de. “Aspiração”, in Poesias completas, op. cit., p. 255.
} 
incomparável, marcou o espírito de Mário de Andrade desde os inícios de sua formação, em 1913. Naquele ano, o jovem Mário recebeu e leu o célebre livro devocional atribuído a Thomas de Kempis ${ }^{295}$, um presente de seu irmão mais velho, que procurava encorajá-lo a superar o abatimento profundo - a "neurastenia" que quase o matou, dizia Mário - provocado pela traumática morte de seu irmão mais moço. Já nesse episódio, vale notar, o sacrifício aparecia a Mário de Andrade como uma solução para a melancolia ${ }^{296}$. Posteriormente, o modelo crístico, que está no núcleo de Há uma gota de sangue em cada poema, como foi visto, terá parte importante no nacionalismo e no engajamento político do escritor, consolidando-se como um aspecto fundamental da atividade intelectual de Mário de Andrade e atravessando a literatura marioandradina do início ao fim - lembre-se, por exemplo, da cena de Café, um dos últimos trabalhos do escritor, na qual um chefe revolucionário morre nos braços de uma "mãe", na figuração de uma pietà. Por isso, dificilmente se compreenderá a obra de Mário de Andrade sem levar em consideração a presença do paradigma de Cristo e sem compreender-lhe o sentido, que tem profundas raízes histórico-sociais.

Um indício de que a importância do sacrifício cristão na reflexão estética e na produção literária de Mário de Andrade relaciona-se com a formação brasileira é a presença decisiva da solução sacrificial em muitas das obras centrais de nossa literatura, embora, é claro, com significados específicos em cada uma delas. Recorde-se o dilema de I-Juca Pirama, que deve escolher entre o sacrifício de si mesmo e a morte social; o complexo sacrificial nos romances indianistas de Alencar ${ }^{297}$; a morte voluntária de Lucíola e Helena, duas mulheres livres e pobres da sociedade imperial escravocrata, que se sacrificam pela honra dos homens ricos que amam; as renúncias, o auto-sequestro e o exílio forçado de Capitu, vítima do poder patriarcal do marido²98; a auto-imolação final de Macunaíma, derradeira e suprema tentativa de fazer com que o mesmo seja o

\footnotetext{
295 Kempis, Thomas de. A imitação de Cristo [séc.XV], São Paulo: Paulinas, 2009.

296 Sobre a influência do catolicismo na formação de Mário de Andrade, ver Lopez, Telê Porto Ancona. Mário de Andrade: ramais e caminho, op. cit., pp. 21-45.

297 Bosi, Alfredo. "Um mito sacrificial: o indianismo de José de Alencar”, in Dialética da colonização, São Paulo: Companhia das Letras, 1992, pp. 176-193.

298 Schwarz, Roberto. “A poesia envenenada de Dom Casmurro”, in Duas meninas, op. cit., pp. 9-41.
} 
outro ${ }^{299}$; e a comunhão, "ao preço de atravessar uma sensação de morte”, com o absolutamente outro, n'A Paixão Segundo G. H., romance marcado pelo sacrifício desde o seu título 300 .

Figurando no centro de alguns dos mais importantes livros do cânone literário nacional, a solução sacrificial adquire no trabalho de Mário de Andrade uma dimensão única em nossas letras, condicionando a totalidade da produção artística e teórica do escritor. Além disso, em Mário, o sacrifício vincula-se profundamente ao cristianismo, a religião sacrificial por excelência, que colocou o sacrifício no núcleo de seu sistema simbólico. Acima de tudo, entretanto, o sacrifício marioandradino adquire especial relevância e interesse porque se relaciona, explícita e essencialmente, às contradições implicadas nas possibilidades de formação individual, social e cultural no Brasil da primeira metade do século XX. Em outras palavras, é a relação visceral com a matéria brasileira que confere, aos sacrifícios de Mário de Andrade, um significado histórico profundo e um lugar privilegiado na extensa lista de imolações representadas ou, podese mesmo dizer, praticadas por nossa literatura.

Em um ensaio conhecido, Anatol Rosenfeld examina o fato de que, em virtude do caráter importado da cultura no Brasil, portanto em virtude da má-formação cultural brasileira, ou da ausência de cultura orgânica, integrada, no país, Mário de Andrade é levado à contradição de procurar a verdade na mentira, o autêntico no falso, o natural no artificial, a sinceridade no disfarce e, no limite, o ser no não-ser. Por exemplo, o esforço para encontrar a língua própria, que exprima a brasilidade, como não o faz o português castiço, consuma-se em uma linguagem que é uma criação estilizada, artificial, que os próprios brasileiros não podem entender sem dicionário ${ }^{301}$. Configura-se uma espécie de aporia em que o genuinidade é a dissimulação, em que o ser é o não ser e vice-versa. Vir a ser por meio do não ser, como vimos, não é o próprio esquema básico do sacrifício? Não por acaso, nos comentários de Rosenfeld sobre o processo de elaboração da língua

\footnotetext{
299 Pasta Júnior, José Antonio. "Tristes estrelas da Ursa - Macunaíma”, in Cadernos Porto \& Vírgula, op. cit., p. 32.

${ }^{300}$ Lispector, Clarice. A paixão segundo G. H., Rio de Janeiro: Rocco, 1998, p. 164.

301 Rosenfeld, Anatol. "Mário e o cabotitnismo", in Texto/Contexto I, São Paulo: Perspectiva, 1996, pp. 185-192.
} 
nacional a que Mário de Andrade se dedicou, o escritor aparece como uma espécie de vítima expiatória, aquela que assume em si mesma as contradições sociais e, por meio dessa incorporação, liberta a coletividade: "Essa língua é sintoma e parte de uma crise, ela como que a precipitou e desta forma contribuiu para que essa crise fosse superada. Ela tinha de ser criada, alguém tinha que suportar todo o peso dessa cisão, travando no campo da própria consciência a batalha inevitável [entre o autêntico e o artificial]"302. Subjaz, na imagem do homem que carrega o peso da crise moral de seu tempo e lugar, a imagem do santo.

Em suas cartas, Mário com freqüência se refere a sua disposição sacrificial como a uma santidade: "Só pode ganhar quem deu tudo de começo e ficou sem nada. Desde então minha vida não tem sido que um viver ganhando", escreveu ele a Drummond, em termos semelhantes aos do poema "Aspiração"303. Essa espécie de "voto de pobreza", que Mário de Andrade pronuncia tantas vezes, será percebido pelo escritor também como princípio de poética do canto gregoriano. Em "Crítica do Gregoriano", escrito em 1926, um de seus mais interessantes e belos ensaios musicais, no qual a sensibilidade profunda em relação ao objeto se alia, com raro equilíbrio, à originalidade e à criatividade características dos textos críticos do autor, diz Mário de Andrade: “O canto gregoriano é pobre. Abandonou a terra e as sensualidades terrestres. [...] Abandonou tudo, conservando apenas o som. [...] Abandonou o metro principalmente. [...] Abandonou também os gêneros. [...] Abandonou os instrumentos. Todos. [...] Mas dessa pobreza não apenas estética mas real e elementar, tirava a sua qualidade melhor: se apagava para se igualar. [...] Como a arte popular, a música gregoriana é por essência anônima. [...] A gente bem sabe que uma melodia popular foi criada por um indivíduo. Porém esse indivíduo, capaz de criar uma fórmula sonora que iria ser de todos, já tinha de ser tão pobre de sua individualidade, que se pudesse tornar assim, menos que um homem, um humano. [...] O gregoriano sintetiza a essência popular anônima e universal da religião de Cristo." 304

\footnotetext{
302 Idem. Ibidem, p. 192.

${ }^{303}$ Andrade, Mário de. A lição do amigo, op. cit., p. 129.

${ }^{304}$ Idem. "Crítica do Gregoriano", in Música, doce música, op. cit., pp. 28-31.
} 
Conforme o leitor terá percebido, Mário de Andrade faz uma clara associação, na passagem acima, entre arte popular e renúncia, expressão coletiva e sacrifício da subjetividade. Com base nisso, assim como em outros textos do autor sobre o assunto $^{305}$, pode-se afirmar que o projeto marioandradino de fazer lírica antiindividualista, ou poesia coletivista, constitui-se, em boa medida, como um programa sacrificial de matiz cristão, digno de um santo. Oneyda Alvarenga recorda que Mário de Andrade costumava referir-se à arte autônoma como a uma perigosa tentação: “Quando o artista atinge pleno domínio de sua técnica, plena consciência de sua arte e de que é um ser singular, no primeiro momento em que a vontade dirigida afrouxar o seu policiamento, ele cairá fatalmente na criação livremente estética"306.

Assim sendo, a intenção de produzir literatura social incluía não apenas a "pobreza" do indivíduo, mas a da própria forma estética, ou do próprio teor estético da arte. De fato, no mesmo ensaio sobre o gregoriano, Mário de Andrade argumenta que o abandono, por parte do cantochão, de todos os elementos - menos o som - que habitualmente fazem parte da música teve o sentido de uma renúncia a tudo o que é “hedonístico", ou seja, propriamente estético, na arte musical: "A música gregoriana tinha função litúrgica, já falei. O papel dela não era encantar nem atrair. Tal papel a gente há-de ainda encontrar noutras manifestações de música religiosa. O papel da música gregoriana foi realizar o cerimonial”307. Para Mário de Andrade, portanto, dar à obra de arte uma função social implica, em alguma medida, conferir-lhe o caráter de um rito. $\mathrm{Na}$ alta maturidade, ao defender a necessidade de uma espécie de "reforma da

\footnotetext{
${ }^{305}$ No artigo "A modinha e Lalo", por exemplo, diz Mário de Andrade, sobre o processo de "criação" da música folclórica, coletiva: "Se o improvisador está inventando, menos que invenção individualista, ele apenas está sendo um agenciador de constâncias coletivas que, de fato, a coletividade adota imediatamente". Como um xamã, o criador popular é o medium por meio do qual as formas sociais se organizam, se integram e falam. Em muitas de suas obras principais, como Macunaíma, Clã do Jabuti e Café, Mário procurou incorporar esse modelo não-dialético - ou, talvez fosse melhor dizer, esse modelo em que a dialética entra em uma espécie de curto-circuito - das relações entre o artista e a sociedade. $\mathrm{O}$ resultado, como temos observado, é a conversão ruinosa, negativa, de máxima desindividuação em extremo individualismo e vice-versa. Andrade, Mário de. "A modinha e Lalo", in Música, doce música, op. cit., p. 329. Sobre a presença e os resultados desse processo em Macunaíma, ver Pasta Júnior, José Antonio. "Tristes estrelas da Ursa - Macunaíma", in Cadernos Porto \& Vírgula, op. cit., p. 30.
}

${ }^{306}$ Alvarenga, Oneyda. Mário de Andrade, um pouco, op. cit., p. 81.

${ }^{307}$ Andrade, Mário de. "Crítica do Gregoriano", in Música, doce música, op. cit., p. 31. 
ópera" ${ }^{308}$, com a intenção de recuperar o valor social do teatro cantado - a ópera era considerada por Mário a forma artística com maior potencial socializante, por reunir, segundo ele, as duas artes "coletivistas" por excelência, ou seja, a música e o teatro -, Mário de Andrade propõe, justamente, o retorno às origens rituais do gênero, contra a apropriação da ópera pela burguesia e contra o que Brecht chamou de "ópera culinária"309.

Nada mais distante do pensamento do dramaturgo alemão, todavia, do que a revalorização direta dos aspectos ritualísticos do teatro, em grande parte responsáveis pela produção de processos identificatórios entre os atores e as personagens, assim como entre o público e a representação teatral ${ }^{310}$. Ora, é justamente a "identificação deslumbrada"311, a empatia entre o espectador/leitor e a obra que caracteriza, para Mário de Andrade, a verdadeira compreensão do objeto artístico, definida pelo escritor como "um ato superior do ser inteiro, pelo qual eu me integro e confundo com a obrade-arte, [...] numa integração, numa empatia em que eu sou Camões ou Magda Tagliaferro"312. Como, espero, se verá ao longo deste trabalho, essa identificação, que se vincula à identificação entre o próprio autor e a obra ${ }^{313}$, completando-se portanto como identificação entre autor, obra e público, é de natureza ritual. A socialização da arte se realiza para Mário de Andrade, portanto, sob o signo da pobreza, da renúncia integral: além da necessidade de o autor sacrificar a própria individualidade no processo de criação da obra, a arte mesma deve renunciar a seu teor estético, renúncia implicada na

308 Andrade, Mário de. "Do teatro cantado" e "Psicologia da criação", in Coli, Jorge. Op. cit., pp. 100-107.

309 Brecht, Bertolt. "Sur l'emploi de la musique pour un théâtre épique", in Écrits sur le théâtre, "La Pléiade", Paris: Gallimard, 2000, p. 705.

310 Ver, de Brecht, "Pequeno organon para o teatro" e "Crítica da identificação", in op. cit., pp. 353-390 e 813-817. Ver, também, sobre a crítica brechtiana da identificação no drama, as duas versões do ensaio de Walter Benjamin, "Qu'est-ce que le théâtre épique?", in Benjamin, Walter. Essais sur Brecht, Paris: La Fabrique, 2003, pp. 18-47.

${ }^{311}$ Andrade, Mário de. Mário de Andrade-Oneyda Alvarenga: cartas, op. cit., p. 285.

${ }^{312}$ Idem. Ibidem, pp. 278-279, grifo meu.

${ }^{313}$ Lembre-se, por exemplo, da tese, exposta no "Prefácio Interessantíssimo", de que a poesia deve ser a pura grafia do lirismo, ou do impulso lírico subconsciente do poeta, tese que se aproxima de uma defesa do princípio surrealista da escrita automática, e que supõe, no limite, conforme demonstrou Roberto Schwarz, que a linguagem seja uma extensão do subconsciente criador, de maneira que este fique como que fisicamente retido no poema. Ver Schwarz, Roberto. "O psicologismo na poética de Mário de Andrade", in A sereia e o desconfiado, op. cit., pp. 13-18. 
reversão da arte no rito. Escrevendo a Drummond, Mário qualifica sua literatura de "pseudo-arte" e afirma: "Minha arte aparente é antes de mais nada uma pregação"314.

Finalmente, para que o rito se consuma, o próprio espectador/leitor deve abolirse na obra. Provocar a "identificação ritual", ora com base no nacionalismo, ora em função do engajamento político, sempre tendo em vista a funcionalização social da arte, constituiu uma das finalidades principais da produção literária de Mário de Andrade, especialmente da poesia. Para isso, Mário impôs a si mesmo, ostensivamente, uma série de sacrifícios dolorosos, que começa com o sacrifício da qualidade artística das obras e culmina, conforme se verá adiante, numa espécie de suicídio. Ao percorrer e expor sua via-crúcis, o escritor procurou não apenas praticar religiosamente esse ideal de abnegação total, mas também servir de exemplo às gerações posteriores. Dizem os versos dos "Poemas da amiga":

"Um desejo de exemplo me inspirava
E você me aceitou entre os santos." 315

Mário de Andrade tinha mesmo o hábito de convocar os escritores mais jovens a seguirem seus passos. O início de sua correspondência com Drummond, por exemplo, é marcado por apelos dessa ordem: "Carlos, devote-se ao Brasil, junto comigo. Apesar de todo o ceticismo, $[\ldots]$ acredite que um sacrificio é lindo"316. A Manuel Bandeira, que questionava com freqüência a autenticidade dos exageros de sua "língua brasileira", Mário protesta: "Sobre isso, Manuel, estou disposto a me sacrificar. É preciso dar coragem a essa gentinha que ainda não tem coragem de escrever brasileiro" 317 . Finalmente, em “Cartaz”, uma espécie de manifesto nacionalista escrito por Mário de Andrade e publicado no "Mês Modernista", promovido pelo jornal carioca A Noite entre dezembro de 1925 e janeiro de 1926, o autor de Macunaíma convida os moços a

\footnotetext{
${ }^{314}$ Andrade, Mário de. A lição do amigo, op. cit., p. 26, grifo meu.

315 Andrade, Mário de. "Poemas da amiga", in Poesias completas, op. cit., p. 275.

316 Andrade, Mário de. A lição do amigo, op. cit., p. 5, grifos meus.

317 Andrade, Mário de. Correspondência - Mário de Andrade \& Manuel Bandeira, op. cit., p. 146.
} 
sacrificarem-se pelo país: “Precisa-se de rapazes bem bestas, acreditando no sacrifício, acreditando no desprendimento, acreditando no apostolado, acreditando na dor e na felicidade'. [...] Assim está escrito no anúncio vistoso de cores desesperadas pintado sobre o corpo indeciso do nosso Brasil" ${ }^{\text {318. O }}$. tom cristão da chamada, curiosamente misturado ao estilo de blague modernista, dispensa maiores comentários.

Nesse ponto, vale notar que é o Brasil, tanto em "Cartaz" como na missiva a Drummond, a entidade por que Mário de Andrade clama abnegação. De fato, a nação constitui a principal "beneficiária" dos sacrifícios marioandradinos - importante indício, além da freqüência com que o sacrifício aparece em nossas letras, de que a solução sacrificial se vincula, no pensamento e na obra de Mário de Andrade, a contradições histórico-sociais especificamente brasileiras. Pode-se dizer que o autor de Macunaíma levou às últimas conseqüências o esforço de "redenção das componentes recalcadas da nacionalidade" 319 , realizado pelos modernistas:

"Nós temos que dar ao Brasil o que ele não tem e que por isso até agora não viveu, nós temos que dar uma alma ao Brasil e para isso todo sacrifício é grandioso, é sublime. [...] Só no Brasil eu penso e por ele tudo sacrifiquei. A língua que escrevo, as ilusões que prezo, os modernismos que faço são pro Brasil. [...] Estraçalho a minha obra. Escrevo língua imbecil, penso ingênuo, só pra chamar a atenção dos mais fortes do que eu pra este monstro mole e indeciso que ainda é o Brasil.” 320

“Todas as questões que são de vida ou de morte prá organização definitiva da realidade brasileira nos levam

\footnotetext{
318 “Cartaz” [1926], in Batista, Marta Rossetti; Lopez, Telê Porto Ancona; Lima, Yone Soares de (orgs.). Brasil: $1^{\circ}$ tempo modernista - 1917/29, São Paulo: IEB/USP, 1972, p. 278.

319 Candido, Antonio. "Literatura e cultura de 1900 a 1945”, in Literatura e sociedade: estudos de teoria e história literária, São Paulo: T. A. Queiroz, 2000, p. 120.

${ }^{320}$ Andrade, Mário de. A lição do amigo, op. cit., p. 6.
} 
pra uma arte de caráter interessado que como todas as artes de fixação nacional só pode ser essencialmente religiosa. [...] E creio que você bem sabe os sacrifícios enormes de mim que fiz nesse sentido.” 321

"Pátria! Que palavra mais anedótica, mais indispensável, [...] essa palavra de milagre, 'encruzilhada' de macumbas, voz sacral mágica, inevitavelmente humaníssima, que faz a gente cair no santo, chorar, beijar a terra, amar os companheiros apesar, e praticar esse ato absolutamente estúpido e contraditório que é sacrificar a vida e morrer." 322

Não por acaso, ao recordar uma ocasião, na juventude, em que admitiu que escreveria até o hino nacional, se necessário fosse para unir os brasileiros, Mário de Andrade, pouco antes de sua morte, compara-se à heroína, mártir e santa nacional por excelência: "Dentro de mim havia um valor, um sabor de Joana d'Arc", escreveu ele 323. Em um ensaio dos anos 1980, Antonio Candido estuda os diferentes sentidos que a palavra "nacionalismo" assumiu ao longo do século XX no Brasil ${ }^{324}$. Para Mário de Andrade, pode-se dizer que, além de significar "desrecalque localista", como para os modernistas em geral, o termo possuía uma inequívoca e singular conotação sacrificial. "O sentimento de brasilidade que transpira ao longo da obra poética de Mário de Andrade é paixão, [...] suplício que redime”, escreveu Victor Knoll ${ }^{325}$. Pode-se mesmo

\footnotetext{
${ }^{321}$ Andrade, Mário de. Cartas de Mário de Andrade a Prudente de Moraes, neto - 1924/36 (organizado por Georgina Koifman), Rio de Janeiro: Nova Fronteira, 1985, p. 248, grifo meu.

${ }^{322}$ Apud Alvarenga, Oneyda. Mário de Andrade, um pouco, op. cit., p.92.

${ }^{323}$ Em carta de 1945 a Rodrigo Mello Franco de Andrade. Apud Andrade, Mário de. A lição do amigo, op. cit., p. 245.

${ }^{324}$ Candido, Antonio. "Uma palavra instável”, in Vários escritos, São Paulo: Duas Cidades, 1995, pp. 293-305.

${ }^{325}$ Knoll, Victor. Paciente arlequinada: uma leitura da obra poética de Mário de Andrade, São Paulo: Hucitec, 1983, p. 155.
} 
dizer que Mário de Andrade viveu e morreu de assumir, de forma irrestrita, fisicamente inclusive, as contradições histórico-sociais de seu país. Ao leitor que sinta, com razão, algum exagero nessa afirmação, vale lembrar que o exagero sempre foi um princípio de ação, de vivência e de expressão de Mário de Andrade e constitui parte essencial da lógica sacrificial marioandradina: "Você quando se apaixona", escreveu Manuel Bandeira a Mário de Andrade em 1928, “de certa maneira se prejudica, perde o senso do equilíbrio, vai sempre além do que deve. Creio que a sua sensibilidade normal já é apaixonada, de sorte que o que para os outros traz de bom o apaixonar-se, para você redunda sempre em excessos"326. A rigor, não há sacrifício sem hybris, ou seja, sem que se vá além de limites em princípio intransponíveis. Ritos sacrificiais invariavelmente envolvem a consagração desmedida da vítima e a transgressão dos limites, fundamentais, que separam a morte e a vida, o sagrado e o profano, o mesmo e o outro $^{327}$. O exagero, tão familiar ao autor de Paulicéia desvairada, é inerente à prática do sacrifício.

Por fim, além das incontáveis renúncias que Mário de Andrade propôs impor a si mesmo, duas características permanentes de sua vida, ou pelo menos da imagem que o escritor fazia de sua vida, contribuem para que sua trajetória tenha o aspecto de uma vita sancti: a pobreza material e o sofrimento físico ${ }^{328}$. Sabe-se que o autor de Macunaíma afirmava gostar de viver bem e que a falta de dinheiro de que padecia, ao contrário do que se lê sobre os santos, não era voluntária, embora o escritor sempre tenha procurado recusar o favor das elites. Em suas cartas, no entanto, Mário faz inúmeras referências às dificuldades financeiras que constantemente atravessava, de tal modo que o conjunto dessas menções passa ao leitor a impressão de uma vida marcada pela aliança com a

\footnotetext{
${ }^{326}$ Andrade, Mário de. Correspondência - Mário de Andrade \& Manuel Bandeira, op. cit., p. 375.

327 Sobre a extrapolação ou a supressão, no sacrifício, dos limites entre o sagrado e o profano, a vida e a morte, o mesmo e o outro, ver Hubert, Henri; Mauss, Marcel. "Ensaio sobre a natureza e a função do sacrifício", in Mauss, Marcel. Ensaios de sociologia, op. cit., pp. 141-227; Lévi-Strauss, Claude. $O$ pensamento selvagem, Campinas: Papirus, 2007, pp. 248-254. Sobre a relação entre excesso e sacrifício, ver Bataille, Georges. La part mandite, Paris: Minuit, 2007, pp. 83-115.

328 Por serem notavelmente freqüentes na correspondência marioandradina e, desse modo, por assinalarem dois aspectos marcantes da vida e da personalidade de Mário de Andrade, as notícias do escritor a respeito de sua penúria econômica e de seu sofrimento físico foram reunidas e publicadas por Carlos Drummond de Andrade, um de seus mais constantes interlocutores para esses assuntos, em especial para as questões relativas à saúde. In Andrade, Mário de. A lição do amigo, op. cit., "Anexos I e II".
} 
pobreza. De maneira análoga, o escritor queixava-se amargamente de seus incontáveis problemas de saúde, em termos que fazem lembrar as narrações dos suplícios dos mártires: “dores cruciantes”, “corpo escalavrado", "pontadas fortíssimas", "vertigens de dor" etc. Nesse sentido, além de numerosíssimas, as informações sobre os males físicos que o vitimavam são insolitamente minuciosas, o que permite entrever, combinado ao sofrimento, certo prazer, de teor masoquista, no ato de descrever os martírios recorrentes $^{329}$. Não é à toa que Mário pretendia escrever um estudo minucioso sobre o "Martírio dos Santos" no folclore brasileiro, prática que ele notava ser bastante comum entre as nossas crenças populares ${ }^{330}$.

\section{*** Afirmação do indivíduo}

No caso de Mário de Andrade, entretanto, a imitação de Cristo não culmina na liberação do escritor das contradições que o enredam. Ao contrário, se cada renúncia, cada negação da subjetividade em favor do social significa, ao mesmo tempo e paradoxalmente, conforme visto, a afirmação tirânica da subjetividade que suprime o social, então o extremo de desindividuação levado a efeito por intermédio da imitatio Christi produz, para desespero do sacrificado, o extremo individualismo. De fato, na carta a Manuel Bandeira que nos vem servindo de fio condutor, na qual o movimento do sacrifício marioandradino se expõe de forma concentrada e da qual partimos para comentar o tema da santidade em Mário de Andrade $^{331}$, a declaração da prática rigorosa da abnegação total converte-se inesperadamente na expansão hiperbólica da própria individualidade, como citado anteriormente, mas talvez necessário repetir aqui: "Nunca me esforcei tanto como agora pra compreender e amar os outros. [...] Não tem mais

\footnotetext{
329 Marcos Antonio de Moraes sugere a existência de certa "volúpia" nas descrições marionadradinas do sofrimento físico. Ver Andrade, Mário de. Correspondência - Mário de Andrade \& Manuel Bandeira, op. cit., p. 313.
}

330 Andrade, Mário de. As melodias do boi e outras peças (preparação, introdução e notas de Oneyda Alvarenga), São Paulo: Duas Cidades/ Instituto Nacional do Livro, 1987, pp. 12-13. Ver algumas descrições feitas por Mário de martírios infligidos às imagens de santos no Brasil em Idem. Música de feitiçaria no Brasil, op. cit., p. 131-132.

${ }^{331}$ Ver, supra, p. 31. 
livro que não valha nada para mim. [...] Meu único ideal é sentir e amar os homens e gozar por isso. [...] E é por esse meu estado de espírito que sou muito mais vasto que vocês". Difícil imaginar semelhante afirmação de si mesmo por parte de um santo. Analogamente, surpreende encontrar, após a profissão de fé do sacrifício do artista à coletividade, a declaração de que a própria coletividade é uma invenção do artista: “Tudo está em ser boneco consciente de sua bonequice, o que também é uma paixão, é amor e desse amor se morre... É a servitude et grandeur militaires do artista. [...] Eu amo o povo porque ele é uma projeção de mim”332. Em Mário de Andrade, o sacrifício tem menos o caráter de uma vocação - ou seja, de uma disposição natural -, como escreveu Jorge Coli, do que de uma decisão consciente, ou melhor, de uma imposição individual ${ }^{333}$.

Comentando a sua disposição de sacrificar a própria obra em beneficio da utilidade social de seu trabalho, Mário declara a Sousa da Silveira: "Não há um só gesto significativo em mim, que não seja uma atitude destinada, um ato consciente de vontade" 334 . Trata-se, portanto, de um verdadeiro programa sacrificial, claramente definido em suas razões, meios e finalidades, proposto de maneira rudimentar em cartas e artigos, baseado em ampla pesquisa e que tende, por tudo isso, a assumir a forma de um sistema. "Não pensem vocês, aí de Minas, que sou um qualquer leviano e estou dando por paus e por pedras sem saber bem o que estou fazendo. A aventura em que me meti é uma coisa séria já muito pensada e repensada”, escreveu Mário a Drummond, a respeito de seu projeto de estilizar o brasileiro vulgar ${ }^{335}$. Dessa força do indivíduo para organizar o próprio destino, Mário dá expressão eloqüente na "Louvação matinal", em cujos versos o poeta atrela o seu destino à vida de seu país:

"Possuir consciência de si mesmo isso é a felicidade,

\footnotetext{
332 Andrade, Mário de. O banquete, op. cit., pp. 63-64.

333 "João sublinha que toda decisão verdadeira na cultura tem um caráter sacrificial (decidere, digo-o novamente, é cortar a garganta da vítima)”. Girard, René. Le bouc émissaire, op. cit., p. 169.

${ }^{334}$ Andrade, Mário de. Mário de Andrade escreve cartas a Alceu, Meyer e outros, op. cit., p. 149.

335 Andrade, Mário de. A lição do amigo, op. cit., p. 25.
} 
Isso é a glória de ser, fazendo o que será. [...]

Sou daqueles que sabem o próprio futuro,

E quando a arraiada começa, não solto a rédea do dia,

Não deixo que siga pro acaso, livre das minhas vontades. [...]

Eu trago na vontade todo o futuro traçado! [...]

Chove tortura, estrala o mal, serenateia a alegria,

Futuro está gravado em pedra e não se apaga mais!" 336

Assim, se o sacrifício marioandradino, por um lado, opera-se como imolação apaixonada, como o gesto extremo realizado no momento paroxístico do desespero, quando a subjetividade, dilacerada por contradições insolúveis, encontra-se à beira da loucura, por outro lado a violência de Mário de Andrade contra si mesmo cumpre-se como um plano, um pouco à maneira de um masoquista que dispõe com método as condições de seu próprio castigo ${ }^{337}$, ou do engenheiro Kirilov, o personagem d'Os demônios, que se mata com base na dedução lógica, por ele realizada, da necessidade do suicídio. De acordo com um crítico, "foi Mário de Andrade um desses escritores que [...] se preparam para a posteridade com a minúcia dos suicidas"338.

Considerando-se a aproximação, sugerida por Roberto Schwarz, entre aspectos das literaturas de Brasil e Rússia do final do século XIX ${ }^{339}$, dois países agrários e préburgueses sob o influxo do prestígio das idéias liberais, vale lembrar que a noção cristã de sacrifício ocupa um lugar central nos romances de Dostoiévski, sendo já notável na expiação redentora de Raskólnikov e cristalizando-se na figura "santa” que é o príncipe Míchkine. Essa presença culmina na narração dramática da repetição, imaginada por Ivan Karamázov, do próprio sacrifício de Cristo, condenado pela Inquisição após descer

\footnotetext{
336 "Louvação matinal”, in Poesias completas, op. cit., pp. 256-257. Note-se que o poema é o segundo de Marco de viração, aparecendo portanto, significativamente, em seguida a "Aspiração", poema em que Mário de Andrade expressa, conforme visto, certo anseio de santidade. Desse modo, é como se Mário, logo após manifestar a aspiração de renunciar a si para unir-se aos homens, dissesse no poema seguinte que fez desse desejo um projeto de vida.

${ }^{337}$ Reik, Theodor. Op. cit., passim.

${ }^{338}$ Ivo, Lêdo. Lição de Mário de Andrade, op. cit., p. 11.

339 Schwarz, Roberto. Ao vencedor as batatas, op. cit., p. 28.
} 
novamente à Terra e tentar restaurar os valores genuínos do cristianismo ${ }^{340}$. No romance dostoiévskiano, as idéias, filhas da razão moderna, provindas do Ocidente, “devem ser purgadas para que nasça a verdade", como disse Roberto Schwarz, em um ensaio sobre Os demônios ${ }^{341}$. Na obra de Dostoiévski, o sacrifício tem o sentido de uma purificação, ou seja, ele proporciona uma redenção ${ }^{342}$, ainda que esta seja "uma utopia inversa", obtida por meio da queda e da destruição ${ }^{343}$. Crime e castigo, por exemplo, encerra-se com o protagonista penitente, beijando a terra da Rússia e convertendo-se ao cristianismo. Nessa linha, o sacrifício cristão, além de assegurar a salvação metafísica e existencial do indivíduo, propicia o revigoramento do sentimento da pátria, revertendo em uma síntese positiva na qual se combinam o resgate do espírito, a recuperação da identidade russa, a união fraternal dos homens e o repúdio das ideologias européias.

Estudar o teor conservador desse quadro, em que a crítica do individualismo inclui a ruína da razão, ultrapassa evidentemente os limites deste comentário. Não obstante, sua menção contribui para assinalar, desde já, certo conservadorismo de fundo na concepção sacrificial que estrutura o nacionalismo e o engajamento político de Mário de Andrade - ainda que o sacrifício marioandradino, ao contrário do dostoiévskiano, seja negativo em toda a linha. Nos romances de Alencar, por exemplo, nos quais a autoimolação do herói ou da heroína funciona positivamente, apesar das lágrimas vertidas, resolvendo as contradições histórico-sociais brasileiras e fundando um mundo novo, marcado pela harmonia, a lógica sacrificial faz parte de uma ideologia conservadora que justifica a colonização moderna e a ordem social injusta por meio da morte voluntária

\footnotetext{
340 "Na imagem do homem ideal ou na imagem de Cristo afigura-se a Dostoiévski a solução das buscas ideológicas. Essa imagem ou essa imagem suprema deve coroar o mundo de vozes, organizá-lo e subordiná-lo". Bakhtin, Mikhail. Problemas da poética de Dostoiévski, Rio de Janeiro: Forense, 2003, p. 97. Sobre a idéia do "suicídio lógico" em Dostoiévski e em Kirilov, ver Camus, Albert. Le mythe de Sisyphe: essai sur l'absurde, Paris: Gallimard, 1999, pp. 142-152.

${ }^{341}$ Schwarz, Roberto. "Para a fisionomia de Os demônios", in A sereia e o desconfiado, op. cit., pp. 73-80.

342 Para uma relativização desse juízo, ver Lukács, Georg. "Dostoievski”, in Ensaios sobre literatura, op. cit., pp. 155-173, especialmente as pp. 171-173.
}

${ }^{343}$ Idem. Ibidem, p. 77. 
do colonizado e dos desvalidos, morte que é representada pelo romancista como nobre gesto de generosidade extrema.

Na obra de Mário de Andrade, diferentemente, o sacrifício não liberta o sujeito nem a sociedade das tensões que os desagregam. Ao contrário, conforme dito, a solução sacrificial aprofunda e intensifica os graves problemas que por meio dela se pretende resolver - ela se dá como puro dilaceramento. Enquanto o sacrifício de Raskólnikov tem por finalidade e efetivamente promove a negação radical do individualismo exacerbado que levou a personagem ao crime, em Mário de Andrade o sacrifício, que também visa à negação do indivíduo, tem como resultado, paradoxalmente, a exacerbação dramática do individualismo. Por esse motivo, no caso marioandradino, cada renúncia exige outra renúncia maior, cada imolação, uma nova imolação, ainda mais violenta.

Conforme ensina a boa teoria, no caso do sacrifício, assim como no caso de todo rito, o regime da reiteração infinita é de rigor: "Há, no sangue vertido, uma virtude que tende a esgotar-se se sangue fresco, de tempos em tempos, não a vem reativar"344. Mesmo o sacrifício do Cristo, o sacrifício único, portador de eficácia absoluta e definitiva, oferecido até o fim dos tempos, o sacrifício que não se precisa portanto repetir, teve de ser inúmeras vezes reiterado pelos mártires e deve ser regularmente reatualizado, no sentido forte do termo, na missa, ainda que de modo cada vez mais simbólico $^{345}$. Para Mário de Andrade, todavia, repetir constantemente o sacrifício não tem propriamente o sentido de renovar as virtudes da solução sacrificial, pois esta, ao invés de purificar, envenena ainda mais. Assim, observa-se na vida, no pensamento e na obra do autor de Macunaíma, além da reiteração contínua das renúncias, uma verdadeira espiral de sacrifícios. Assim, não basta sacrificar a qualidade estética das obras em benefício da função social da arte, pois o resultado dessa operação, como vimos, foi a produção de trabalhos ainda menos sociais. São necessárias outras e maiores imolações.

\footnotetext{
344 Girard, René. Op. cit., p. 293. No mesmo sentido, escreve o Autor em outra obra: “Ao acabar com o círculo vicioso da violência, a violência contra a vítima expiatória ao mesmo tempo inicia outro círculo vicioso, o do rito sacrificial”. Girard, René. A violência e o sagrado, São Paulo: Paz e Terra, 1998, p. 122.

345 Herrenschmidt, Olivier. "Sacrifice symbolique ou sacrifice efficace", in Izard, Michel; Smith, Pierre (orgs.). La fonction symbolique: essais d'anthropologie, Paris: Gallimard, 1979, pp. 171-191.
} 
Dissemos que o caráter autônomo da criação artística, no qual Adorno via, justamente, o gestus mais importante de oposição, portanto de crítica, da obra de arte à sociedade $^{346}$, era considerado por Mário de Andrade, ao contrário, um sinal de indiferença social e de elitismo ${ }^{347}$. A esse juízo vincula-se uma concepção aristocrática da figura do artista, o que pode parecer surpreendente, em se tratando do escritor brasileiro que maiores esforços empreendeu para realizar e estimular o desenvolvimento de uma arte integrada ao povo e aos movimentos da sociedade. Mário de Andrade, o intelectual que celebrou, um a um, ritualisticamente, os funerais simbólicos dos poetas parnasianos, dos "mestres do passado"348, o autor que se dedicou intensamente a conhecer e assimilar as formas artísticas populares para aproximar da matéria histórica a sua obra literária, nunca deixou de acreditar que o artista, em virtude do refinamento de sua sensibilidade e de sua formação, pertence a uma aristocracia do espírito ${ }^{349}$. Por isso, ao final da explicação de Café, sua obra literária mais "social", Mário de Andrade lamentará: "Há-de ser sempre amargo ao artista verdadeiro, não sei si artista bom, mas verdadeiro, sentir que esperdiça deste jeito em problemas transitórios”350.

Dois anos mais tarde, n'O banquete, que pode ser considerado o "testamento estético" do escritor, o reconhecimento dessa natureza aristocrática do artista e da

\footnotetext{
346 "A arte se torna social por meio de sua oposição à sociedade, e ocupa essa posição somente como arte autônoma. [...] Cristalizando-se em si mesma como coisa única para si, em vez de obedecer às leis sociais e qualificar-se como 'socialmente útil', a arte critica a sociedade por sua simples existência. [...] Nada existe de puro, de completamente estruturado segundo sua lei imanente, que não exercite uma crítica sem palavras e denuncie a degradação provocada por uma situação que evolui para a sociedade de troca total, na qual tudo existe apenas para-outra-coisa. [...] Tanto quanto uma função social pode ser prevista para obras de arte, é a sua ausência de função". Adorno, Theodor W. Teoria Estética, op. cit., pp. 225-7.

${ }^{347}$ Salvo nos ensaios, já mencionados, em que Mário expõe a idéia de "técnica pessoal”, de acordo com a qual o cultivo da técnica é definido como processo de moralização e desalienação do artista. Ver "O artista e o artesão" e "Atualidade de Chopin", in O baile das quatro artes, op. cit., pp. 9-33, 137-165. Ver também "Elegia de abril", in Aspectos da literatura brasileira, op. cit., em especial as pp. 216-217.

348 Na série de artigos intitulada "Os mestres do passado", escrita em 1921 para o Jornal do Comércio, e que se encontra integralmente reproduzida em Brito, Mário da Silva. História do Modernismo brasileiro, I-Antecedentes da Semana de Arte Moderna, Rio de Janeiro: Civilização Brasileira, 1978, pp. 254-309. Vale notar que, no artigo sobre Vicente de Carvalho, o sexto da série, Mário separa beleza e expressão na poesia, ou seja, já nos textos de juventude Mário de Andrade opera os conceitos de sua poética de maneira não dialética. Ver $O p$. cit., p. 299.
}

${ }^{349}$ Ver Coli, Jorge. Música final, op. cit., p. 305.

${ }^{350}$ Andrade, Mário de. Café, in Poesias completas, op. cit., p. 422. 
distância irredutível que o separa do povo adquire uma feição dramática e conduz a uma representação trágica da condição do artista erudito. Quando o Pastor Fido sugere a Janjão que faça "arte de combate que alcance o povo", o compositor - que exprime, conforme dito, as opiniões e os sentimentos de Mário de Andrade - responde:

"Não creio, infelizmente, que seja esse o meu papel de artista erudito. Pelo menos enquanto o povo for folclórico, como falei. Seria me adaptar falsamente a sentimentos e tendências que não poderão nunca ser os meus. Eu sou de formação burguesa cem por cento, você esquece? E pela arte, pelo cultivo do espírito e refinamento gradativo, eu me aristocratizei cem por cento. Moral, intelectualmente, é incontestável que eu sou um aristocrata" 351 .

Sendo assim, a produção de arte engajada não implica apenas o sacrifício da qualidade artística da própria obra, mas os sacrifícios, muito mais difíceis e dolorosos, das tendências naturais, do gosto pessoal, dos interesses espontâneos e das aspirações íntimas do artista. Em 1930, portanto já depois de ter feito suas duas longas viagens ao norte do país e de ter publicado muitas de suas obras fundamentais, Mário expõe a Bandeira essa "dimensão maior” de seu sacrifício:

"Quando falei que houve um sacrifício de mim, e há, no que faço, creio que não me referi ao sacrifício da linguagem que embora exista, tenha existido principalmente nos primeiros tempos, não tem a mínima importância pra ninguém, nem pra mim. O sacrifício penoso é o das minhas liberdades morais cerceadas; o mais penoso ainda é o das

${ }^{351}$ Andrade, Mário de. O banquete, op. cit., p. 63. 
minhas verdades intelectuais, independentes até de mim, e por mim mesmo rejeitadas no que escrevo e ajo, em proveito da normalização, da fixação, da permanência de outras verdades humanas, sociais que eu friamente sei que são mais importantes." 352

A posição social e ideológica do intelectual, em particular a do escritor, tornouse especialmente problemática desde quando, na conhecida frase de Marx, "os fogos de artifício de Lamartine transformaram-se nas bombas incendiárias de Cavaignac"353, ou seja, quando a burguesia finalmente abandonou a máscara universalista de sua ideologia e se afirmou como classe dominante, nos massacres de junho de 1848 em Paris ${ }^{354}$. “Tantas promessas, tantos tiros de fuzil!", escreveu Baudelaire, com sua habitual ironia, sobre a carnificina, que o marcou decisivamente ${ }^{355}$. Configurada e declarada a nova luta de classes, a proletarização do escritor moderno, de formação burguesa, "não [se dará] sem lutas amargas, não sem conflitos extremamente difíceis”, como disse Benjamin ${ }^{356}$. O engajamento passa a implicar uma traição de classe, pois além de supor que o artista "mude de lado", presume que ele coloque sua formação intelectual a serviço da luta dos despossuídos ${ }^{357}$. No Brasil dos anos 1920-30, considerando-se que a desigualdade entre as classes era escandalosa e o grau de exclusão civil e cultural não diferia muito dos níveis da sociedade escravista do final do século XIX, o salto que era desafiado a dar o

\footnotetext{
352 Andrade, Mário de. Correspondência - Mário de Andrade \& Manuel Bandeira, op. cit., p. 520.

353 Marx, Karl. A luta de classes em França de 1848 a 1850, I - A derrota de junho de 1848. In Marx, Karl; Engels, Friedrich. Obras escolhidas - I, Lisboa: Avante, 1982, p. 230.

354 "Ao transformar o seu lugar de morte em lugar de nascimento da república burguesa, o proletariado obrigou-a ao mesmo tempo a manifestar-se na sua forma pura como Estado, cujo objetivo confesso é eternizar a dominação do capital e a escravidão do trabalho". Marx, Karl. Ibidem, p. 232.

355 Sobre o impacto exercido pelos massacres de junho de 1848 sobre os escritores mais importantes da época, ver o estudo de Dolf Oehler, O Velho Mundo desce aos infernos: auto-análise da modernidade após o trauma de junho de 1848 em Paris, São Paulo: Companhia das Letras, 1999. A citação de Baudelaire encontra-se nesse livro, p. 347.

356 Benjamin, Walter. "O autor como produtor", in Obras escolhidas, volume I-Magia e técnica, arte e política, op. cit., p. 135.

357 Schwarz, Roberto. "Nunca fomos tão engajados", in Seqüências brasileiras, São Paulo: Companhia das Letras, 1999, p. 172.
} 
intelectual que pretendia engajar-se era particularmente vertiginoso. Entre os escritores modernistas brasileiros, Mário de Andrade foi o que experimentou esses conflitos de modo mais amplo, dramático e consciente. Em carta de 1944, comentando "O carro da miséria", um de seus poemas mais explicitamente políticos, escrito em dois momentos pós-revolucionários - dezembro de 1930 e outubro de 1932 -, Mário se refere às lutas internas, que cindiam seu espírito nos inícios da Era Vargas, entre sua posição de classe e a disposição de negá-la:

"O assunto do poema [...] é a luta do burguês gostosão, satisfeito das suas regalias, filho-da-putamente encastoado nas prerrogativas da sua classe, a luta do burguês pra abandonar todos os seus preconceitos e prazeres em proveito de um ideal mais perfeito. Ideal a que a inteligência dele já tinha chegado por dedução, lógica e estudo, e que a noção moral aprovava e consentia, mas a que tudo o mais nele não consentia, não queria saber. [...] Todo esse drama foi um sofrimento muito grande em mim.” 358

Em seguida, na mesma carta, o autor de Café reconhece que jamais conseguiu levar a cabo esse processo, que é um processo de migração de classe:

"Evidentemente, como sensibilidade, eu não creio que eu possa, que ninguém possa superar a marca da sua classe e de toda a sua vida, a vida que o fez em menino e na mocidade. Isto é: superar, pode, porque a superação é

\footnotetext{
358 Andrade, Mário de. 71 cartas de Mário de Andrade, op. cit., p. 88.
} 
sempre um valor nascido na consciência e realizado na vontade. Mas não pode mudar." 359

Nesse quadro, a negação da posição de classe não pode ocorrer senão sob a forma do sacrifício:

"As datas do desfazimento em mim dos prazeres e prerrogativas da minha classe são essas: 1930, "O Carro da Miséria"; 1932, 2a versão e definitiva do mesmo; 1933, “Grão Cão do Outubro" e enfim, fins de 1934 o artigo me confessando 'coram populo' comunista. Sem sê-lo e sem sê-lo nenhum, hélas!" 360

As razões de a "proletarização" de Mário de Andrade assumir feição sacrificial, contudo, são mais objetivas do que subjetivas. Faltava, ou era muito tênue, na realidade social brasileira da época, a mediação que permitiria ao escritor completar essa conversão pessoal e deixar de conceber a arte e a política como atividades estranhas uma à outra, em outras palavras de compreender os teores estético e social da criação artística como essencialmente distintos: essa mediação seria a luta de classes $^{361}$. De acordo com uma historiadora, a repressão secular da organização das classes populares no Brasil, em especial a partir da abolição da escravatura, tornava quase impossível, nos anos 1930, identificar uma experiência unificada de resistência dos grupos oprimidos ${ }^{362}$.

Um incipiente movimento operário ganhara vitalidade ao longo da década de 1910, particularmente em São Paulo. Sua força manifestava-se em greves cada vez mais

\footnotetext{
${ }^{359}$ Idem. Ibidem, pp. 92-93.

${ }^{360}$ Idem. Ibidem, pp. 91-92.

361 "Mário de Andrade morreu numa hora em que os rumos políticos da sua terra ainda não se tinham definido". Alvarenga, Oneyda. Mário de Andrade, um pouco, op. cit., p. 101.

362 Dias, Maria Odila Leite da Silva. "Política e sociedade na obra de Sérgio Buarque de Holanda", in Candido, Antonio (org.) Sérgio Buarque de Holanda e o Brasil, São Paulo: Fundação Perseu Abramo, 1998, p. 18.
} 
freqüentes e amplas, por meio das quais os trabalhadores e os sindicatos dos vários setores da produção industrial paulista começavam a organizar-se como classe ${ }^{363}$. Os pontos mais altos desse processo, como é sabido, foram as greves gerais de 1917 e 1919, que paralisaram a capital: "1917 inaugura a fase revolucionária das greves: até 1919, elas atingem intensidade e um grau tático nunca alcançados. O operariado toma consciência de que pode açambarcar o poder. [...] As famosas paredes destes anos mostram a força e a possibilidade de vitórias gerais do proletariado"364. A partir de então, a repressão do movimento do proletariado, antes intermitente, embora não menos violenta, torna-se verdadeiramente sistemática, desdobrando-se em um aspecto propriamente repressivo, com base na aliança efetiva dos industriais com a polícia ${ }^{365}$, e em um aspecto "regulatório", baseado na ação do Estado, e que culminaria na legislação trabalhista de Vargas e na criação, durante o Estado Novo, de uma "estrutura sindical corporativa e oficialista" ${ }^{366}$, que transferia o controle dos sindicatos ao governo ${ }^{367}$. Noutras palavras, a organização dos trabalhadores, que começava a esboçar-se como força autônoma, estruturada e unificada, ou seja, como um autêntico movimento social de classe, passou a ser sistematicamente sufocada e desarticulada pelas classes dominantes e dirigentes do país, que não encontraram grandes dificuldades para desmanchar uma organização que sequer ultrapassara os rudimentos de seu processo de formação.

Um dado que ilustra o êxito dessa empresa repressiva, por meio da qual as elites nacionais, nos anos 1920-30, puseram um freio na luta de classes no Brasil, é o fato de que, enquanto o $1^{\circ}$ de maio de 1919 , no Rio de Janeiro, reuniu por volta de 60 mil

\footnotetext{
${ }^{363}$ Uma extensa reunião de documentos que fazem parte desse processo foi feita por Edgard Carone em Movimento operário no Brasil (1877-1944), São Paulo: Difel, 1984.

364 Carone, Edgard. A República Velha (instituições e classes sociais), op. cit., p. 226. Ver também Beiguelman, Paula. A formação do povo no complexo cafeeiro: aspectos politicos, op. cit., pp. 190-200.

365 Dean, Warren. A industrialização de São Paulo (1880-1945), São Paulo: Difel, s/d, pp. 174-180.

366 Alencastro, Luiz Felipe de. “A pré-revolução de 30", in Novos Estudos CEBRAP, nº 18, São Paulo: setembro de 1987, p. 20.

${ }^{367}$ Fausto, Boris. "Estado, classe trabalhadora e burguesia industrial (1920-1945): uma revisão", in Novos Estudos CEBRAP, no 20, São Paulo: março de 1988, pp. 6-37. Skidmore, Thomas. Brasil: de Getúlio a Castelo, São Paulo: Paz e Terra, 1992, pp. 62-63. Faoro, Raymundo. Os donos do poder: formação do patronato político brasileiro, São Paulo: Globo, 2008, pp. 754-757, 807.
} 
pessoas na Praça Mauá, apenas 20 mil pessoas, aproximadamente, compareceram ao meeting do $1^{\circ}$ de maio de 1929 , também na Capital Federal ${ }^{368}$. A organização proletária nascente se dissolveu: "No momento de refluxo, os líderes do movimento operário [...] não sabiam como dirigir um recuo organizado da massa em face da onda de repressão que se desencadeava"369.

Mário de Andrade, vale lembrar, abordou o assunto de forma direta. Seu conto “Primeiro de Maio", escrito entre 1934 e 1942, narra a decepcionante experiência de um carregador, o 35, que sai às ruas de São Paulo para comemorar o Dia do Trabalho e, em vez de encontrar uma festa proletária, depara uma cidade quase deserta, ocupada pela polícia, e uma celebração oficial no Palácio da Indústrias, presidida pelos patrões e pelo governo. Desse modo, Mário de Andrade expõe o controle e a repressão, por parte do Estado e dos industriais, do movimento operário e da luta de classes nos anos 1930-40 no Brasil, assim como a desarticulação da classe trabalhadora - uma "desorganização trágica", segundo o narrador -, resultante desse estado de coisas: em suas andanças pela cidade, o carregador não encontra um companheiro com quem se identifique ${ }^{370}$. "Mário de Andrade está dizendo que 35 é desorganizado em sentido político. Mesmo sendo área de influência do Partido Comunista (ou por isso mesmo), não recebeu nenhuma direção sobre o que fazer nesse Primeiro de Maio", escreveu Iná Camargo Costa, em um ensaio sobre o conto ${ }^{371}$. Nesse quadro, a natureza da celebração do Dia do Trabalho é confusa e indeterminada para o carregador, algo entre a festa e a luta, e sua disposição solidária e participativa se funda no sentimento cristão de fraternidade abstrata e na disposição para o sacrificio: "O 35 percebeu que se rasgava todo por 'drento' dum espírito generoso de sacrifício. Estava outra vez enormemente piedoso, morreria sorrindo, morrer..."372. Dada

\footnotetext{
368 Ver Pinheiro, Sérgio Paulo. “O proletariado industrial na Primeira República”, in Fausto, Boris (org.). História geral da civilização brasileira, tomo III: o Brasil Republicano, $2^{\circ}$ volume - sociedade e instituições (1889-1930). Rio de Janeiro: Bertrand Brasil, 1997, pp. 135-178.

369 Konder, Leandro. A derrota da dialética: a recepção das idéias de Marx no Brasil, até o começo dos anos 30, São Paulo: Expressão Popular, 2009, p. 160.

${ }^{370}$ Andrade, Mário de. "Primeiro de Maio", in Contos novos, Belo Horizonte: Itatiaia, 1999, pp. 35-42.

371 Costa, Iná Camargo. "Mário de Andrade e o Primeiro de Maio de 35", in Trans/Form/Ação: Revista de Filosofia, vol. 18., São Paulo, Unesp, 1995, p. 37. Outra leitura do conto marioandradino encontra-se em Rabello, Ivone Daré. A caminho do encontro, op. cit., pp. 63-74.
}

372 Andrade, Mário de. "Primeiro de Maio", in Contos novos, Belo Horizonte: Itatiaia, 1999, p. 38. 
a falta de organização política dos trabalhadores e a ausência de qualquer perspectiva de vitória do movimento operário, a única imagem nítida que o 35 tem de seu engajamento na luta de classes é uma imagem sacrificial. A realidade confirmará em parte a fantasia do carregador: sua decepcionante experiência no Primeiro de Maio assumirá a feição de uma via-crúcis, mas sem redenção ${ }^{373}$.

Além da debilidade da luta de classes no Brasil durante o período de atividade intelectual de Mário de Andrade, outro fator histórico contribuiu para que o escritor não tenha encontrado as mediações que lhe possibilitariam dialetizar as relações entre arte e política: trata-se da precariedade da divulgação e da recepção do pensamento de Marx no Brasil durante as décadas de 1920-30. Sem exagero, pode-se dizer que o marxismo brasileiro pautou-se de maneira quase exclusiva, à época, pelo modelo do socialismo russo, constituindo-se em grande medida sob a forma de uma divulgação maciça do estalinismo $^{374}$. Em um artigo de 1930, Mário demonstra ter consciência desse estado de coisas ao criticar a identificação das idéias comunistas com a Rússia e ao afirmar, a respeito da palavra "comunismo", que "ninguém sabe o que ela é"375. Todavia, o autor de Macunaíma travará contato menos superficial com as concepções de Marx apenas a partir de $1933^{376}$. Ao longo dos anos 1930, Mário de Andrade inclina-se ao comunismo, mas sempre de maneira hesitante e, sobretudo, sem jamais fundamentar sua simpatia em uma compreensão profunda do materialismo histórico e das condições de realização da luta revolucionária no Brasil.

Ao que tudo indica, eram os ideais de fraternidade humana e de redenção dos oprimidos que especialmente atraíam Mário de Andrade para o comunismo ${ }^{377}$. De fato, ao longo de sua trajetória ideológica, o escritor tentou constantemente unificar, em seu espírito e em seu pensamento, comunismo e cristianismo, dilacerando-se quando sentia

\footnotetext{
373 Costa, Iná Camargo. "Mário de Andrade e o Primeiro de Maio de 35”, in op. cit., pp. 37-41.

${ }^{374}$ Idem. Ibidem.

${ }^{375}$ Andrade, Mário de. “Comunismo”, in Táxi e crônicas do Diário Nacional, op. cit., pp. 231-233.

${ }^{376}$ Lopez, Telê Porto Ancona. Mário de Andrade: ramais e caminho, op. cit., p. 49.

377 Moacir Werneck de Castro considera "romântico" o marxismo de Mário. Ver Castro, Moacir Werneck de. Mário de Andrade: exílio no Rio, op. cit., pp. 75-76.
} 
que as duas doutrinas se negavam reciprocamente ${ }^{378}$. No Café, a obra mais engajada de Mário, a revolução social, além de calcada no modelo dos ritos de vegetação, é tingida por certo messianismo, na figuração de um êxodo ${ }^{379}$, na evocação do Homem Zangado, o "justiçador moreno" que tem vem libertar o povo e na promessa de uma idade ainda por vir, o "Dia Novo", em que todas as injustiças serão sanadas ${ }^{380}$. Em outra obra tardia, O banquete, o princípio revolucionário é identificado por Mário à idéia cristã de charitas, de tal maneira que o vermelho comunista é associado ao vermelho do amor fraternal $^{381}$. Não por acaso, Roberto Schwarz identificou, no projeto nacionalista marioandradino e no esforço sistemático do escritor de aproximar a sua arte dos pobres, uma generosidade de teor paternalista, "os melhores sentimentos de que seria capaz o paternalismo levado ao limite dele mesmo", o que restringe o alcance crítico e social do programa. Este, que à primeira vista objetivava a promoção do popular, tinha fundo elitista, e voltava-se antes de tudo à desalienação da elite cultivada do país ${ }^{382}$. O próprio escritor reconheceria, com pesar, em 1942, a natureza "aristocrática" de seu programa:

"Não tenho a mínima reserva em afirmar que toda a minha obra obra representa uma dedicação feliz a problemas do meu tempo e minha terra. Ajudei coisas, maquinei coisas, fiz coisas, muita coisa! E no entanto me sobra agora a sentença de que fiz muito pouco, porque todos os meus feitos derivaram duma ilusão vasta. E eu que sempre pensei, me senti mesmo, sadiamente banhado de amor humano, chego no declínio da vida à convicção

\footnotetext{
${ }^{378}$ Idem. Ibidem, pp. 47-71.

379 Sobre a relação entre êxodo e messianismo, ver Queiroz, Maria Isaura Pereira de. O messianismo no Brasil e no mundo, São Paulo: Dominus/USP, 1965, pp. 3, 142-194.

${ }^{380}$ Andrade, Mário de. Café, in Poesias completas, op. cit., pp. 442-449. Queiroz, Maria Isaura Pereira de. Op. cit., p. 3.

${ }^{381}$ Andrade, Mário de. O banquete, op. cit., p. 68-69.

382 Schwarz, Roberto. “Outra Capitu”, in Duas meninas, op. cit., pp. 137-144.
} 
de que faltou humanidade em mim. Meu aristocracismo me puniu. Minhas intenções me enganaram.” 383

Escrevendo sobre Mussórgsqui, mas também sobre si mesmo, Mário de Andrade explicita, de fato, a distância que o separa das massas populares, afirmando em seguida que a sua adesão ao povo é uma decisão individual que contraria sua disposição natural:

"Embora convivendo com o povo russo, Mussórgsqui está longe de ser um homem do povo, de se identificar com o povo, e nem sequer se poderá afirmar que tenha amado o povo. [...] Por vezes se percebe em Mussórgsqui uma complacência excessiva com o lado grotesco das pessoas do povo. [...] Tudo o que vê, tudo o que vive no povo lhe maltrata os instintos aristocráticos. [...] Mussórgsqui não sofre as desgraças do povo, mas se decide a aderir a ele. $\mathrm{O}$ gesto dele não deriva de amores instintivos, de nenhuma voz de classe. Tem toda a grandeza individual duma escolha e duma adesão. Mussórgsqui é um aristocrata que adere às forças populares do futuro. [...] Esse sacrificado [...] nos aparece hoje como um primeiro clarão da Rússia dos nossos dias. Porque na verdade, e conscientemente, ele adere à Rússia e ao seu destino." 384

Para Mário de Andrade, fazer arte de caráter social é, em última instância, um ato artificial, que vai de encontro a sua formação intelectual:

\footnotetext{
383 Andrade, Mário de. "O movimento modernista”, in Aspectos da literatura brasileira, op. cit., p. 277, grifo meu.

${ }^{384}$ Andrade, Mário de. "Mussórgsqui”, in Coli, Jorge. Música final, op. cit., p. 91, grifo meu.
} 
"Para nós, pros da nossa geração vinda dos 800, [...] nos é por assim dizer impossível obter qualquer espécie de.. de espontaneidade, meu Deus!, de solidariedade humana em estado poético, em estado de escritura!... Não é que não tenhamos essa solidariedade humana, mas pelo vício da educação artística que tivemos, e também pelo total desfibramento moral do fim do século, que foi o leite em que bebemos, essa solidariedade não consegue se transfundir por si mesma, por espontaneidade dela em poesia, em prosa de ficção, em artigo de inteligência lógica." 385

Mário de Andrade refere-se aos modernistas. Assim como ele, todas as figuras principais do modernismo eram da "geração vinda dos $800 " 386$. O trecho acima pertence a uma carta de 1944. Dois anos antes, em uma célebre conferência, o escritor criticara o caráter absenteísta e aristocrático do modernismo, enfatizando a proximidade existente entre o movimento modernista e a "nobreza local", ou seja, a oligarquia cafeeira de São Paulo 387.

De sua parte, Mário procurou superar a falta de compromisso político-social do movimento de 1922 - o que implicava superar o próprio nacionalismo festivo, de salão, deste - dando a seu engajamento uma dimensão propriamente sacrificial, o que confere a seus esforços de integrar a cultura da nação e de aproximar-se pessoal e artisticamente do povo uma dramaticidade de que o diagnóstico de Roberto Schwarz, comentado acima, surpreendentemente passa ao largo. Em carta de 1925 a Manuel Bandeira, Mário

\footnotetext{
${ }^{385}$ Andrade, Mário de. A lição do guru (cartas a Guilherme Figueiredo, 1937-1945), op. cit., p. 103.

386 Manuel Bandeira nasceu em 1886, assim como Tarsila do Amaral. Villa-Lobos, no ano seguinte. Anita Malfatti, em 1889. Oswald de Andrade, em 1890. Menotti del Picchia e Ronald de Carvalho, em 1892. Mário de Andrade, em 1893. Vítor Brecheret, em 1894.

387 Andrade, Mário de. "O movimento modernista" [1942], in Aspectos da literatura brasileira, op. cit., pp. 253-280.
} 
procura marcar a distância que o separava dos outros modernistas, uma distância que se funda, segundo ele, justamente em sua disposição para o sacrifício:

"Quando foi para destruir, tempo em que a blague e o espírito valem mais que o saber, estávamos todos juntos. Porém depois esse tempo passou. Eu fui o mais sacrificado jurei pra mim que havia de provar que não era o cabotino besta que pensavam e que a verdade em que estamos era justa e propícia. Minha vida e meus trabalhos não tem sido mais do que isso e como a minha verdade é apaixonante me apaixonei por ela e toda a minha vida se dedicou pra ela. Com uma sinceridade máscula com um desprendimento que é o meu verdadeiro título de glória. Tudo tenho sacrificado por ela. Tudo isto são coisas que os de dentro, os amigos percebem facilmente. E como não estão pra fazer o mesmo porque os sacrifícios são guaçus mesmo a comparação fatalmente se dará no espírito, na consciência deles. Como na minha. [...] Eu me dei um destino e eles ficaram sem se dar destino." 388

O sacrifício aparece a Mário de Andrade, pois, como a principal, senão única, mediação - extrema e intrinsecamente contraditória mediação, como temos observado por meio da qual o modernismo poderia afastar-se da oligarquia cafeeira, deixar de ser uma aristocracia do espírito e adquirir valor social. Nesse sentido, além da debilidade da luta de classes no Brasil da primeira metade do século XX, a própria estrutura préburguesa da sociedade brasileira à época, estrutura que fazia com que os intelectuais pertencessem à classe dominante ou desta dependessem, constituía uma das principais razões para que a produção de uma arte integrada ao povo passasse, no pensamento de

\footnotetext{
388 Andrade, Mário de. Correspondência-Mário de Andrade \& Manuel Bandeira, op. cit., p. 246.
} 
Mário de Andrade, pela solução sacrificial ${ }^{389}$. No âmbito de uma sociedade marcada por uma rudimentar divisão social do trabalho, cujas raízes remontam à prática multissecular do escravismo no Brasi ${ }^{390}$, assim como por um apenas embrionário mercado de trabalho intelectual, o imperativo de conferir eficácia política à arte implica, para Mário, não apenas o sacrifício da qualidade estética da obra de arte, mas a renúncia aos anseios de realização individual do próprio artista, na medida em que este, por nascimento, formação ou necessidade, vincula-se profundamente à "aristocracia": "Nós temos que adotar os princípios da arte-ação. Sacrificar as nossas liberdades, as nossas veleidades e pretensõezinhas pessoais; e colocar como cânone absoluto da nossa estética, o princípio de utilidade", escreve Mário n'O banquete ${ }^{391}$. A experiência do fracasso dessa disposição sacrificial, contudo, já se exprimira nos seguintes versos de Paulicéia desvairada:
"Os meus joelhos têm quedas muito crentes
Que vão bater no peito do Senhor;
Mas os meus suspiros muito louros
Entreteceram-se com a rama dos cafezais..." 392

Por suposto, a exigência de abdicação, em benefício da coletividade, dos anseios pessoais do artista conduz, no limite, à demanda do sacrifício da condição mesma de artista. Em 1942, Mário recordaria a realização, de sua parte, desse gesto sacrificial de grande monta:

\footnotetext{
389 Sobre a relação profunda entre os modernistas e as classes dominantes no Brasil, ver Miceli, Sérgio. "Intelectuais e classe dirigente no Brasil (1920-1945)", in Intelectuais à brasileira, São Paulo: Companhia das Letras, 2008, pp. 69-291.

390 Oliveira, Francisco de. "A emergência do modo de produção de mercadorias: uma interpretação teórica da economia da República Velha no Brasil”, in op. cit., pp. 402-407.

391 Andrade, Mário de. O banquete, op. cit., p. 130.

392 Andrade, Mário de. “As enfibraturas do Ipiranga", in Paulicéia desvairada, in Poesias completas, op. cit., p. 109.
} 
"Abandonei, traição consciente, a ficção, em favor de um homem-de-estudo que fundamentalmente não sou. Mas é que eu decidira impregnar tudo quanto fazia de um valor utilitário, um valor prático de vida, que fosse alguma coisa mais terrestre que ficção, prazer estético, a beleza divina." 393

A renúncia integral à própria condição de artista chegou a ser considerada como um suicídio por Mário de Andrade - que afirmava ser, antes de tudo, um poeta. Quando, em 1935, aceitou o convite de Paulo Duarte para dirigir o Departamento de Cultura de São Paulo, Mário encontrava-se dilacerado entre a sua sensibilidade de artista e o dever de participar das lutas sociais. Os poemas engajados que vinha de escrever, em especial o "Carro da miséria", e um artigo recente em que se declarara comunista não haviam diminuído suas angústias, muito menos tinham-no libertado das contradições insolúveis que o consumiam. Ao contrário, eles intensificaram o drama, pois tanto o engajamento do poema quanto a afirmação de que era comunista, de acordo com Mário de Andrade, “não passavam de uma mentira desesperada", que o enredava ainda mais "na indecisão tumultuária, na insolubilidade sufocante em que vivia" ${ }^{394}$. Nesse contexto, a proposta do Departamento de Cultura, segundo a expressão do próprio escritor, foi sua "salvação":

"O Departamento vinha me tirar do impasse asfixiante. [...] Ia agir. Me embebedar de ações de iniciativas, de trabalhos objetivos, de luta pela cultura. Certamente não posso encarar isso como uma perfeição do meu ser interior. [...] Mas era sempre me conservar utilitário, dando uma pacificação às minhas exigências morais de escritor, pois tirava o escritor de foco, botando o foco no funcionário que

\footnotetext{
393 Andrade, Mário de. "O movimento modernista”, in Aspectos da literatura brasileira, op. cit., p. 279.

394 Andrade, Mário de. 71 cartas de Mário de Andrade (coligidas e anotadas por Lygia Fernandes), Rio de Janeiro: São José, s/d, p. 87.
} 
surgia. Me suicidei sim. [...] Me lembro perfeitamente bem que disse também pra você que encarava isso como um suicídio. [...] Percebi a possibilidade de um suicídio satisfatório e me suicidei. O Departamento é o meu túmulo.” 395

Novamente, a prática do sacrifício - agora, um sacrifício próximo ao sacrifício supremo, o da própria vida - solucionava, in extremis, as contradições marioandradinas, as polaridades irredutíveis que cindiam o pensamento estético de Mário de Andrade. Vale notar que esse suicídio do artista vinha evitar o suicídio do homem: em carta de 1944 a Carlos Lacerda, Mário recorda que "as insolubilidades em 35 chegaram a um clímax tamanho, [...] que estava mesmo perseguido pela idéia de suicídio, quando a criação do Departamento de Cultura me salvou"396. Durante o tempo em que dirigiu o Departamento, Mário levou o seu sacrifício, como de hábito, às últimas conseqüências: nenhuma obra literária publicou, salvo duas ou três crônicas, abandonou por completo a prosa de ficção e não compôs senão alguns poucos poemas ${ }^{397}$. Dedicou-se integralmente às novas atividades, ligando-se "xifópagamente" ao Departamento, na expressão de Paulo Duarte:

"Você não imagina o que tem sido a minha vida. [...] Contei outro dia pro Carlos Lacerda, domingo passado, primeiro dia depois dm mês, em que eu fazia qualquer coisa que não fosse Departamento!!! [...] Não faço projetos, deixei os que tinha comigo pra mais tarde (ou quem sabe nunca?...), estou cheio, trabalhando com paixão, com violenta paixão, nesta primeira vida minha em que tomo contato burocrático

\footnotetext{
395 Andrade, Mário de. Cartas a Murilo Miranda (1934-1945), op. cit., pp. 39-41.

${ }^{396}$ Andrade, Mário de. 71 cartas de Mário de Andrade, op. cit., pp. 87-88.

397 Ver Lopez, Telê Porto Ancona. "Cronologia geral da obra de Mário de Andrade publicada em volume", in Revista do Instituto de Estudos Brasileiros, n 7, São Paulo: IEB/USP, 1969, pp. 139-172.
} 
com o povo e com a vida. Não recuso que a burocracia e este contato novo são horríveis, e experiências ferozes para mim, mas é a vida!" 398

Como se sabe, o golpe de Vargas interrompeu os trabalhos de Mário de Andrade quando estes apenas começavam a produzir seus primeiros resultados: "Muito pouco se preservou do Departamento de Cultura depois da saída de Mário de Andrade. [...] Quase todos os projetos foram interrompidos" ${ }^{" 399}$. Apenas três anos após sua criação, arruinavase o Departamento, com a mesma rapidez, segundo as impressões de Lévi-Strauss, com que as construções da São Paulo dos anos 1930 convertiam-se em ruína, mal haviam acabado erguer-se, portanto antes de terem uma história ${ }^{400}$. Em suma, a modernização conservadora, para cujas contradições Mário não encontrou senão a solução sacrificial, ao mesmo tempo impedia que o sacrifício se justificasse e não resultasse em pura destruição:

"Sacrifiquei por completo três anos de minha vida começada tarde, dirigindo o Departamento de Cultura. Digo por completo porque não consegui fazer a única coisa que, em minha consciência, justificaria o sacrifício: não consegui impor e normalizar o D. C. na vida paulistana. [...] Não me sinto propriamente triste com estas coisas, me sinto especialmente deserto. É uma vagueza, uma vacuidade monótona." 401

\footnotetext{
${ }^{398}$ Andrade, Mário de. Cartas a Murilo Miranda (1934-1945), op. cit., p. 18.

399 Abdanur, Elizabeth. "Parques infantis de Mário de Andrade", in Revista do Instituto de Estudos Brasileiros, $\mathrm{n}^{\circ}$ 36, São Paulo: IEB/USP, 1994, p. 270. Uma recordação apaixonada e minuciosa da idealização, das atividades e do desmanche do Departamento de Cultura é feita por Paulo Duarte, companheiro de Mário na empreitada, em Mário de Andrade por ele mesmo, op. cit., pp. 49-144.

${ }^{400}$ Lévi-Strauss, Claude. Tristes tropiques, Paris: Plon, 1966, pp. 78-79.

${ }^{401}$ Duarte, Paulo. Op. cit., pp. 158-159.
} 
As palavras de Mário de Andrade sugerem que ele perdeu, juntamente com o Departamento de Cultura, a si mesmo: "uma vacuidade monótona". Em verdade, era o conjunto de sacrifícios a que se entregara de corpo e alma ao longo de sua atividade intelectual, da publicação de Há uma gota de sangue em cada poema à "aventura" do Departamento, que aparecia a Mário de Andrade como um grande sacrifício infecundo, mais especificamente como um sacrifício fundador, ou como um bauopfer - o sacrifício sangrento celebrado no ato de fundação de uma casa ${ }^{402}$ - puramente ruinoso.

\section{*** Bildung sacrificial}

Com efeito, em um poema de juventude, o escritor, ainda confiante, comparou seu programa sacrificial a um "projeto de casa" 403 . A seu modo, tratava-se de um projeto ambicioso de formação da cultura nacional, o que implicava a realização de um processo formativo do indivíduo e a da sociedade ${ }^{404}$. Mário de Andrade, "o pensador do modernismo", como disse Antonio Candido ${ }^{405}$, foi quem levou mais longe a proposta modernista de "redescobrir" a cultura brasileira tendo em vista a sua integração no presente. Sem risco de exagero, pode-se dizer que toda a atividade intelectual de Mário, a partir do início dos anos 1920, se organiza com base na consciência do caráter por assim dizer rarefeito e inorgânico da formação dessa cultura, consciência que se desdobra nas constatações complementares de que "o Brasil, hélas! é uma coisa completamente... em formação ainda" e de que "a nossa formação nacional não é natural, não é espontânea", ou seja, de que o processo formativo era incipiente e não se

\footnotetext{
402 Eliade, Mircea. O sagrado e o profano, op. cit., pp. 52-55.

${ }^{403} \mathrm{Na}$ "Louvação matinal", que é de 1925. In Andrade, Mário de. Poesias completas, op. cit., p. 256.

${ }^{404}$ De acordo com Lafetá, a busca da identidade coletiva vincula-se intimamente, em Mário de Andrade, à procura da identidade individual. Lafetá, João Luiz. Figuração da intimidade: imagens na poesia de Mário de Andrade, São Paulo: Martins Fontes, 1986.
}

405 Candido, Antonio. “Uma palavra instável”, in Vários escritos, op. cit., p. 298. 
completaria por si mesmo, sem o empenho dos $\operatorname{artistas}^{406}$. À vista disso, Mário orienta seu trabalho em função de uma decidida e ampla operação de incorporar e atualizar a herança cultural, popular e erudita, do país: “nós já temos um passado guaçu e bonitão pesando em nossos gestos; o que carece é conquistar a consciência desse peso, sistematizá-lo e tradicionalizá-lo, isto é, referi-lo ao presente", disse o escritor em 1925 , em uma entrevista a um jornal carioca ${ }^{407}$. Noutras palavras, era preciso constituir uma tradição, ou seja, recolher e integrar em larga escala, sob o signo da atualidade, o passado cultural brasileiro, o que significa estabelecer com a nossa precária herança cultural e os seus problemas internos uma relação de continuidade, adensamento e superação que é, salvo engano, o próprio processo de formação, tal como entendido pela boa crítica, em especial por Antonio Candido e Roberto Schwarz ${ }^{408}$.

Solicitado, portanto, por uma formação mal resolvida, e movido por uma ilimitada disposição para o sacrifício, o que inclui o desejo de sobrepujar as próprias forças, Mário de Andrade se dedica a um colossal esforço construtivo e integrador, que se desdobra em um conjunto de providências que extrapola a literatura e abrange praticamente todas as áreas da cultura: "Resolvi trabalhar a 'matéria' brasileira, especificá-la, determiná-la o quanto em mim e na complexidade dela. [...] Não havia folclore musical brasileiro. Fiz folclore musical brasileiro. Não havia crítica de arte em S. Paulo, e a pouca existente era mais que péssima. Fiz crítica de arte. Não havia um tratado de poética, moderno, adaptável ao tempo. Fiz um. Não havia História da Música em nossa língua. As existentes eram simplesmente porcas. Fiz uma, bem milhor que as outras. Etc." ${ }^{409}$. No campo literário, Mário procede a uma verificação crítica da tradição

\footnotetext{
406 Andrade, Mário de. Correspondência - Mário de Andrade \& Manuel Bandeira, op. cit., p. 608; Idem. "Tristão de Ataíde" [1931], in Aspectos da literatura brasileira, op. cit., p. 16.

${ }^{407}$ Andrade, Mário de. “Assim falou o papa do futurismo”, in Entrevistas e depoimentos, op. cit., p. 19.

408 Ver Candido, Antonio. Formação da literatura brasileira, Belo Horizonte: Itatiaia, 1997. Schwarz, Roberto. "Sobra a Formação da literatura brasileira" e "Os sete fôlegos de um livro", in Seqüências brasileiras, op. cit., pp. 17-23, 46-58. Idem, "Nacional por subtração", in Que horas são?, op. cit., pp. 29-48. Idem. "Acumulação literária e nação periférica", in Um mestre na periferia do capitalismo, op. cit., pp. 221-243. Ver também Arantes, Paulo Euardo. "Providências de um crítico literário na periferia do capitalismo", in Arantes, Otília Beatriz Fiori; Arantes, Paulo Eduardo. Sentido da formação, op. cit., pp. 11-66.

409 Em carta de 1935 a Sousa da Silveira. Andrade, Mário de. Mário escreve cartas a Alceu, Meyer e outros, op. cit., p. 150.
} 
nacional em extensão e profundidade que somente se encontram no trabalho de Machado de Assis. Desse modo, a reflexão marioandradina compreende ensaios diversos sobre a poesia dos românticos, em especial sobre Gonçalves Dias, Álvares de Azevedo e Castro Alves, estudos específicos de obras capitais da nossa prosa, como os romances de Manuel Antônio de Almeida e de Raul Pompéia, um exame - em sua maior parte equivocado - da situação de Machado de Assis na literatura brasileira, balanços da produção contemporânea e inúmeros textos sobre a literatura popular. Mesmo o Parnasianismo, de que os modernistas propunham a abolição em toda linha, recebeu de Mário, em plena época de combate ao passadismo, uma série de estudos, já mencionada, em que o autor de Paulicéia desvairada analisa as obras dos principais poetas da escola de Bilac, ironicamente denominados "mestres do passado", os quais são negados, um a um, por Mário de Andrade, que mesmo nesse caso evitou fazer tabula rasa do passado. Este não era entendido pelo escritor "como peso morto, mas como elemento dinâmico e irresolvido, subjacente às contradições contemporâneas" ${ }^{\prime 410}$. Sua retomada extensa e profunda fazia parte do processo de "conquista do caráter específico [da literatura brasileira], daquele caráter em que ela é original, daquilo enfim em que ela representa uma contribuição insoluvelmente nacional à história da inteligência humana" ${ }^{411}$. A recuperação não-tradicionalista da tradição tinha como objetivo, portanto, a superação da dependência cultural e a formação de uma literatura autônoma, arraigada na matéria brasileira e, por isso mesmo, destituída de caráter provinciano - a seu modo, Mário sustentava a concepção dialética de que somente por meio do particular é possível alcançar o universal, embora essa passagem apareça muitas vezes, em suas reflexões e em sua literatura, como imediata.

Considerado em perspectiva histórica, o programa nacionalista de Mário reanima o "pragmatismo", como disse Antonio Candido, dos escritores românticos brasileiros, os quais, na esteira da Independência, esforçaram-se para dotar o país livre de uma literatura equivalente às européias, que exprimisse de maneira adequada a

\footnotetext{
${ }^{410}$ Schwarz, Roberto. "Nacional por subtração", in Que horas são?, op. cit., p. 31.

${ }^{411}$ Andrade, Mário de. "Literatura nacional” [1939], in O empalhador de passarinho, op. cit., p. 170.
} 
realidade nacional, o que tornou o Romantismo um dos momentos decisivos da formação da literatura brasileira ${ }^{412}$. O sentimento profundo de missão, a renúncia à liberdade criativa em favor da função prática da obra literária, o sacrifício da qualidade artística, a pesquisa que ultrapassa o terreno específico das belas-letras, entre outros aspectos que marcam o conjunto das obras dos nossos românticos, encontram-se, magnificados, no centro da atividade intelectual de Mário de Andrade: "Nós, os modernistas da minha geração, sacrificávamos conscientemente, pelo menos alguns, a possível beleza das nossas artes, em proveito de interesses utilitários. A arte se empobrecia de realidades estéticas, dissolvida em pesquisas. [...] Então, fomos descobrir, mais nas revistas de combate que nos livros de filosofia, a palavra salvadora que acalmava as nossas ambições estéticas maltratadas: pragmatismo. Aquilo, gente, eram pragmatismos também! Eram as necessidades da hora, as verdades utilitárias por que nos sacrificávamos" ${ }^{413}$. Noutros termos, o Modernismo recuperava a natureza empenhada que caracteriza alguns dos momentos mais fortes da literatura brasileira, e que se havia perdido por completo durante o "reinado" parnasiano. Todavia, se a retomada do nacionalismo romântico é um traço geral dos autores modernistas ${ }^{414}$, foi sobretudo Mário quem levou o compromisso com o país às suas últimas conseqüências, gravando-lhe a marca de sangue sobre cada página de sua obra - uma disposição que o escritor, embora lhe reconhecesse o caráter artificial, considerava imprescindível em países novos como o Brasil, onde a cultura, a sociedade e o indivíduo aguardavam definição.

Nas concepções de Mário, com efeito, a formação da cultura incluía, em grande medida, a formação da sociedade e a do indivíduo. Em plena Amazônia, Mário afirma que a falta de uma "civilização" própria "por detrás” provoca no “indivíduo" brasileiro uma "incapacidade realizadora do ser moral". Na mesma linha, ao lamentar que "não existe uma obra, em toda a ficção nacional, em que possamos seguir uma linha de

\footnotetext{
${ }^{412}$ Candido, Antonio. Formação da literatura brasileira, op. cit., vol. 1, pp. 26-28; vol 2, pp. 11-17.

${ }^{413}$ Andrade, Mário de. "Elegia de Abril" [1941], Aspectos da literatura brasileira, op. cit., p. 214.

414 Sobre as semelhanças entre o romantismo e o modernismo brasileiros, ver Candido, Antonio. "A literatura na evolução de uma comunidade", in Literatura e sociedade, op. cit., pp. 139-167, mais especificamente as pp. 160-167.
} 
pensamento, nem muito menos a evolução de um corpo de idéias", ou seja, ao deplorar a ausência de uma cultura orgânica, integrada, Mário observa que os heróis, no romance brasileiro de seu tempo, correspondem sempre a um modelo especial de "fracassado", distinto dos fracassados da literatura européia: "Um Dom Quixote fracassa, como fracassam Otelo e Madame Bovary. Mas estes, como quase todos os heróis da arte, são seres dotados de ideais, de ambições enormes, de forças morais, intelectuais, físicas. [...] são enfim seres capazes de se impor, conquistar suas pretensões vencer na vida, mas que no embate contra forças maiores são dominados e fracassam. Mas em nossa literatura de ficção, romance ou conto, o que está aparecendo com abundância não é este fracasso derivado de duas forças em luta, mas a descrição do ser sem força nenhuma, do indivíduo desfibrado, incompetente pra viver, e que não consegue opor elemento pessoal nenhum, nenhum traço de caráter, nenhum músculo como nenhum ideal, contra a vida ambiente" 415 . Pode-se dizer que Mário se queixa da ausência do "modelo individualista ou 'napoleônico', cujo pressuposto é a ordem burguesa moderna, modelo que seria decisivo para o romance europeu, de Julien Sorel e Rastignac a Raskolnikoff", e cuja inadequação na sociedade brasileira, em que se combinam formas sociais burguesas e pré-burguesas, e na literatura que a pretenda representar, foi observada por Roberto Schwarz ${ }^{416}$. Mário, por sua vez, via o fenômeno sob o prisma da "ausência de caráter" do brasileiro, que ele considerava decorrente da falta de cultura orgânica no país - os problemas da identidade individual e da constituição da linguagem nacional encontram-se, por exemplo, como notou Anatol Rosenfeld, intimamente entrelaçados no pensamento e na obra do escritor ${ }^{417}$. A formação de uma tradição cultural estável aparece, nesse quadro, como a condição principal - e muitas vezes suficiente - para a formação do indivíduo e da sociedade, pois também a formação social dependia, sobretudo, conforme o horizonte do programa nacionalista marioandradino, pelo menos até meados da década de 1930, da realização do processo formativo no âmbito da cultura. Na poesia de Mário, com efeito, a identidade do eu-lírico e a identidade

\footnotetext{
${ }^{415}$ Andrade, Mário de. "Elegia de Abril” [1941], Aspectos da literatura brasileira, op. cit., p. 212-213.

${ }^{416}$ Schwarz, Roberto. "Duas notas sobre Machado de Assis”, in Que horas são?, op. cit., p. 175.

417 Rosenfeld, Anatol. "Mário e o cabotitnismo", in op. cit., 185-192.
} 
coletiva não apenas se articulam como, na maioria das vezes, como se verá adiante, se superpõem sem mediação, sendo que ambas se relacionam à constituição dos próprios poemas, configurando um alinhamento das esferas subjetiva, social e cultural que se consuma em Macunaíma.

Ao alinhar esse três planos, o projeto artístico de Mário de Andrade tem algo de um projeto clássico. Referindo-se a Brecht, escreveu José Antonio Pasta Júnior: "Fazerse clássico [...] significa postular, basicamente, o mesmo valor de referência monumental e incontornável, os mesmos alcance coletivo e influência modelar - valor de paradigma -, contando, por isso, apenas com a força de seu próprio trabalho em marcha, com a capacidade de organizá-lo e potenciá-lo para a consecução de um fim que, por definição, parece exceder desmedidamente o seu alcance, por maior que ele seja"418. À sua maneira, Mário de Andrade confere a seu projeto artístico e cultural características semelhantes. Encontram-se, no programa do escritor, a natureza sistemática, a intenção de constituir referência privilegiada, a ambição desmedida e a capacidade de organização do trabalho tendo em vista a sua inscrição na história. Acrescente-se a isso a incorporação e o diálogo com a totalidade histórica, social e geográfica da formação cultural brasileira, constituindo-se a sua obra, "como trânsito entre as linguagens do mundo [do Brasil, no caso marioandradino] que nela encontram reunião e conflito" ${ }^{419}$. Por fim, Mário de Andrade dedicou-se a uma quantidade espantosa de gêneros e atividades: escreveu romances, poemas, contos, crônicas, cartas, diários de viagem, artigos jornalísticos, libretos de ópera, ensaios críticos sobre literatura, artes plásticas, música e cinema, estudos teóricos sobre estética, trabalhos sobre folclore e medicina, uma história da música e até uma peça musical; foi, também, administrador e legislador da cultura, professor de estética e pesquisador de campo. O conjunto indica um intelectual que organizou a sua obra de sorte que ela se inscrevesse profundamente na história da cultura brasileira, constituindo-se como referência e procurando adquirir, dessa forma, uma qualidade de permanência.

\footnotetext{
418 Pasta Júnior, José Antonio. Trabalho de Brecht, op. cit., p. 23.

${ }^{419}$ Idem. Ibidem, p. 21.
} 
Nessa linha, vale lembrar que Mário de Andrade iniciou, em 1943, a publicação de suas Obras completas, para as quais se previam vinte volumes. A essa altura, a crítica já o reconhecia como um clássico de nossas letras. Em 1944, a Revista Acadêmica, dirigida por Murilo Miranda, organizou um número de homenagem a Mário de Andrade e em 1946, um ano após a morte do escritor, Antonio Candido declarou: "Para encontrarmos, na literatura brasileira um morto da importância de Mário de Andrade, é preciso remontar ao ano de 1908, à morte de Machado de Assis" ${ }^{\text {"20 }}$. Oito anos mais tarde, a comparação com Machado de Assis seria retomada por Lêdo Ivo, em um ensaio tão original quanto unilateral, em que Mário de Andrade é praticamente apresentado como um escritor parnasiano. O texto pode ser considerado a culminação do processo de classicização do autor de Macunaíma pela crítica. De acordo com Lêdo Ivo, Mário de Andrade, "ourives insaciável do Construído, $[. .$.$] desde a mocidade se construiu para$ o esplendor das obras completas. [...] Tornado vivo e abordável pela morte, deixando à posteridade um nome que lhe assegura a posição de verdadeiro clássico do modernismo, ele é realmente uma lição, uma lição tão grande quanto a de Machado de Assis" ${ }^{421}$.

Entretanto, um dos pontos nos quais Mário mais insistia a respeito de seu programa estético era o da transitoriedade de sua obra. "Não tenho a mínima intenção de ficar. [...] Minhas forças, meu valor, meu destino, estou convencido disso, é ser transitório", escreveu ele a Bandeira, em 1924 $4^{422}$. Vinte anos depois, o escritor afirmaria exatamente o mesmo, o que confirma, no mínimo, a solidez da convicção: "Onde você se engana redondamente é no imaginar que pela interioridade do meu brilho eu possa 'ficar'. Não tem ninguém mais transitório que eu, me'rmão"'23. De certa forma, é como se Mário de Andrade pretendesse durar desaparecendo, gravar-se em pedra evolando-se em música... E não é a própria música, a arte que a literatura marioandradina incorporou em toda linha, uma exteriorização que vem a ser destruindo-se a si mesma, como disse

\footnotetext{
420 Candido, Antonio. "Mário de Andrade", in Revista do Arquivo Municipal, CVI, São Paulo: jan/fev de 1946, p. 69.

${ }^{421}$ Ivo, Lêdo. Lição de Mário de Andrade, op. cit., pp. 12-13, 22, grifo meu.

${ }^{422}$ Andrade, Mário de. Correspondência - Mário de Andrade \& Manuel Bandeira, op. cit., pp. 146-147

${ }^{423}$ Castro, Moacir Werneck de. Mário de Andrade: exílio no Rio, op. cit., p. 207
} 
Hegel $^{424}$, ou que somente adquire existência real mediante o seu próprio passamento ${ }^{425}$ ? “A minha vaidade hoje é de ser transitório", escreveu Mário a Drummond, registrando o paradoxo de uma intenção de permanência por meio da perecibilidade ${ }^{426}$.

Conforme visto, quando Mário afirmava que desejava ser um exemplo para as gerações futuras, era a sua ilimitada disposição sacrificial que ele se referia. O sacrifício está portanto no centro do projeto artístico e cultural marioandradino, do qual ele é a origem e o meio de realização. Por essa razão, o leitor não encontrará, no conjunto da obra de Mário de Andrade, a feição acabada, a distância, a clareza e a reprodutibilidade modelar próprias das obras clássicas ${ }^{427}$. Ao contrário, a arte de Mário, em especial sua poesia, é muitas vezes difícil, obscura e, em casos extremos, incompreensível; suas soluções formais e estilísticas, de tão pessoais, parecem irrepetíveis; suas estruturas, na maioria dos casos, dão a impressão do informe, como nos belos poemas longos, cujo andamento lembra o fluxo dos rios caudalosos, ou em Macunaíma, que é uma rapsódia e tem muito do andamento de uma improvisação; por fim, o próprio gesto da literatura marioandradina, tanto em relação ao leitor como em relação à matéria histórica sobre a qual ela trabalha, suprime a distância, conforme se verá neste trabalho. Ao todo, um conjunto de características opostas ao que se espera de uma classicidade.

Como se não bastasse, além de presentes na obra do escritor, essas qualidades anticlássicas são essenciais ao projeto estético-cultural de Mário e decorrem da aparente insolubilidade das contradições histórico-sociais que esse projeto gigantesco se dedica intensamente a resolver. Lembre-se, por exemplo, da necessidade de sacrificar a "forma perfeita", para que a literatura adquirisse eficácia social, ou da eliminação mutuamente destrutiva da distância entre o individual e o coletivo, para que a obra tivesse a função prática que norteava o programa nacionalista-engajado do escritor.

A própria obscuridade de tantos trabalhos marioandradinos, obscuridade que não raro culmina no hermetismo, relaciona-se à matéria brasileira sobre a qual se debruçou,

\footnotetext{
${ }^{424}$ Hegel, G. W. F. Curso de Estética: o Sistema das Artes, São Paulo: Martins Fontes, 1996, p. 289.

${ }^{425}$ Dahlhaus, Carl. Esthetics of music, Cambridge: Cambridge University Press, 1995, p. 12.

${ }^{426}$ Andrade, Mário de. A lição do amigo, op. cit., p. 6.

${ }^{427}$ Pasta Júnior, José Antonio. Trabalho de Brecht, op. cit., pp. 107-232, passim.
} 
com o objetivo de compreendê-la, alterá-la e dar-lhe forma, o projeto artístico e cultural do escritor. A linguagem obscura, muitas vezes cifrada, de inúmeras poesias de Mário parece ligar-se ao esforço de encontrar e exprimir o sentido de uma realidade históricosocial que "rouba o fôlego especulativo" 428 , pois marcada por paradoxos aparentemente irredutíveis: “a dor dos irreconciliáveis vive aqui”, escreveu Mário, refletindo sobre o Brasil 429 .

Particularmente, o quadro social que o escritor deparava caracterizava-se pelo vínculo, contraditório ao extremo, entre modernização vertiginosa e preservação do arcaísmo, vínculo que se atava com particular violência na São Paulo dos anos 1920-30, onde o surto modernizador nas esferas mercantil e industrial, a reboque da prosperidade do comércio cafeeiro e baseado na exploração maciça e desumana da força de trabalho, não representou a promoção da cidadania, muito pelo contrário. Como se sabe, as condições de trabalho durante a República Velha, tanto no campo como nas cidades, nas plantações de café como nas fábricas, podem ser consideradas, sem forçar a nota, uma variante da escravidão ${ }^{430}$. Após a Revolução de 1930, quando se criaram as condições institucionais para a acumulação industrial-urbana de capital, a situação não melhorou substancialmente, ao contrário das aparências: renovaram-se, ampliando-se, as relações e estruturas arcaicas do "antigo regime" no seio da "nova ordem". As leis do trabalho vinham, na prática, institucionalizar a tradicional compressão dos salários das massas trabalhadoras, garantindo à indústria o direito de exploração desumana da mão-de-obra. A derrubada das oligarquias conduzia à ditadura, em vez de à participação política das camadas populares - primeiramente, de 1930 a 1937, "uma ditadura de classe burguesa dissimulada e paternalista"; após o golpe que inaugura o Estado Novo, "uma ditadura de classe burguesa aberta e rígida"431.

\footnotetext{
${ }^{428}$ A expressão, que se refere ao quadro social brasileiro, é de Paulo Arantes. Ver, do Autor, "Providências de um crítico literário na periferia do capitalismo", in Arantes, Otília Beatriz Fiori; Arantes, Paulo Eduardo. Sentido da formação, op. cit., p. 12.

429 Andrade, Mário de. O turista aprendiz (estabelecimento do texto, introdução e notas de Telê Porto Ancona Lopez), Belo Horizonte: Itatiaia, 2002, p. 149.

${ }^{430}$ Carone, Edgard. A República Velha (instituições e classes sociais), op. cit., pp. 191-194. Beiguelman, Paula. A formação do povo no complexo cafeeiro: aspectos políticos, op. cit., pp. 57-216.

${ }^{431}$ Fernandes, Florestan. A revolução burguesa no Brasil, op. cit., p. 398.
} 
No plano econômico, o adensamento do mercado interno, baseado em investimentos externos, não formava uma economia autônoma, mas aumentava a dependência multissecular em relação ao capital estrangeiro ${ }^{432}$. Ao mesmo tempo em que prosperava, a burguesia inibia a expansão de uma ordem competitiva e a mudança da estrutura social, coligava-se aos setores "atrasados" das elites locais e, na posição de "sócio menor", unia-se ao "imperialismo econômico" ocidental. Adotava, assim, o espírito mandonista oligárquico e contribuía para a dominação econômica do país por parte das grandes corporações das nações hegemônicas. Tendo em vista que a sua força relativa baseava-se nas vantagens imediatas oferecidas pelo "desenvolvimento desigual e combinado" do país, a classe burguesa não pretendia a ruptura com as estruturas préburguesas e com a condição dependente do Brasil, muito pelo contrário. Assim, nos anos seguintes a 1930, mediante a compressão do preço da força de trabalho e por meio da instrumentalização do Estado em função de seus interesses particulares, as elites urbanas e rurais lograram bloquear a instauração de uma democracia burguesa no país e aumentar ainda mais a concentração social e regional da riqueza, que já era altíssima ${ }^{433}$. Potencializavam-se, em larga escala, os privilégios do Brasil velho - e os benefícios deles decorrentes -, nos quadros de uma ordem "moderna" que se fundava no arcaico e o repunha. Estas breves observações bastam para concluir que Mário de Andrade tinha diante de si uma realidade histórico-social singular, que desnorteava os que procuravam compreendê-la: “a expansão do capitalismo no Brasil se dá introduzindo relações novas no arcaico e reproduzindo relações arcaicas no novo", escreveu Francisco de Oliveira ao analisar o impulso de industrialização os anos 1930, formulando o paradoxo ${ }^{434}$.

A obscuridade de muitas poesias de Mário de Andrade constitui uma resposta, muitas vezes consciente, a uma matéria histórica que, por ser tão contraditória, parece inexplicável. Em outras palavras, a linguagem obscura, que em muitos casos se

\footnotetext{
432 Furtado, Celso. Formação econômica do Brasil, São Paulo: Companhia Editora Nacional, 2003, pp. 195-203, 233-242. Prado Júnior, Caio. História econômica do Brasil, São Paulo: Brasiliense, 2002, pp. $287-300$

433 Fernandes, Florestan. A revolução burguesa no Brasil, op. cit., pp. 280-325. Oliveira, Francisco de. "Crítica à razão dualista", in Crítica à razão dualista/O ornitorrinco, op. cit., pp. 29-69.

${ }^{434}$ Oliveira, Francisco de. Ibidem, p. 60.
} 
aproxima de uma língua secreta, com seus símbolos e significados próprios, coalhada de "sinais" e de "metaforismo contínuo", constitui-se como um modo ou um esforço de exprimir o que parece ser inexprimível, ou melhor, de dizer o sentido de uma realidade social marcada por paradoxos que lhe conferem uma feição incompreensível e misteriosa $^{435}$.

Para dar forma poética às suas impressões da São Paulo "arlequinal” dos anos 1920, burguesa e pré-burguesa, "meio fidalga, meio barregã"436, "feita de asfalto e de lamas de várzea"437. cujo progresso decorria de uma atividade econômica de natureza tipicamente... colonial, Mário de Andrade propõe o emprego de uma linguagem "sem exatidão aparente", de "forma dubitativa"438. O paradigma dessa nova linguagem, conforme explica o poeta no "Prefácio Interessantíssimo", é justamente a música, a arte na qual "o que é dito é determinado e oculto ao mesmo tempo"439, e que "reveste as coisas mais misteriosas em uma linguagem misteriosa" ${ }^{440}$. Paulicéia, a cidade superlativamente contraditória, onde convivem "luz e bruma", "cinza e ouro", onde se alternam a "escuridão dum meio-dia" e a "treva cor de cal", será apreendida por meio de uma linguagem de caráter musical. Particularmente, Mário de Andrade recorre à idéia de "harmonia", elaborando, no prefácio ao livro, o conceito de "verso harmônico", núcleo da poética de Paulicéia desvairada. Resultado de um aproveitamento original, algo simbolista, da técnica futurista das palavras em liberdade ${ }^{441}$, o verso harmônico, de acordo com o escritor, constitui-se por justaposição de vocábulos soltos, ou seja, que

435 Para Luiz Costa Lima, o "núcleo irremomível da poesia marioandradina", considerado pelo crítico também como o principal defeito desta, é "o caráter misterioso de sua clarificação", a "clarificação não clarificada”. Lima, Luiz Costa. Op. cit., p. 104.

436 Andrade, Mário de. Paulicéia desvairada, in Poesias completas, op. cit., p. 98.

${ }^{437}$ Idem. Ibidem, p. 83.

${ }^{438}$ Idem. "Prefácio Interessantíssimo", ibidem, pp. 65, 72.

439 Adorno, Theodor W. "Fragment sur les rapports entre musique et langage", in Quasi una fantasia, Paris: Gallimard, 1982, p. 4.

${ }^{440}$ A frase é de Wackenroder. Apud Dahlhaus, Carl. The idea of absolute music, Chicago: University of Chicago Press, 1991, p. 66.

${ }^{441}$ A "ponte" entre o Simbolismo e as vanguardas Mário a encontrou nas obras de Verhaeren e de Jules Romains, que estão entre as principais influências sofridas por Paulicéia desvairada. Em sentido análogo, a obra de Soffici teria apresentado ao poeta brasileiro as possibilidades de um futurismo humanista, de tendência impressionista. Porto Ancona Lopez, Telê. "Arlequim e modernidade", in Mariodeandradiando, op. cit., pp. 17-36. 
não se organizam segundo a lógica da sintaxe, como no exemplo seguinte: “Arroubos... Lutas... Setas... Cantigas... Povoar!". Desse modo, o sentido do verso se forma à medida que as ressonâncias das palavras se sobrepõem e combinam: "Si pronuncio 'Arroubos', como não faz parte de frase (melodia), a palavra chama a atenção para seu insulamento e fica vibrando [...]. 'Lutas' não dá conclusão alguma a 'Arroubos'; e, nas mesmas condições, fica vibrando com ela"442. Desprovido de estrutura sintática, o verso harmônico não contém, segundo Mário, "pensamento inteligível”, sendo por isso mais apropriado para registrar realidades obscuras, como a do inconsciente, onde mora o lirismo, do que o "verso melódico", o verso tradicional, que exprime idéias precisas. O argumento ganha interesse na medida em que a teoria de Mário de Andrade se refere a poemas que representam uma experiência lírica específica: a da São Paulo dos anos 1920, uma capital "moderna" da periferia do capitalismo. Com efeito, Mário afirmou certa vez que, em Paulicéia desvairada, "canta regionalmente a cidade materna", de modo que o conjunto de poemas representa uma tentativa de apreensão integral das dissonâncias da capital paulista no auge da modernização conservadora baseada na riqueza do café ${ }^{443}$.

Como disse Adorno, “a transformação da linguagem em uma justaposição em que os elementos se articulam de modo diverso de como o fazem no juízo apodíctico é de natureza musical"444. Na mesma linha, ao associar a elisão da sintaxe à música, Mário deixa claro que as "harmonias poéticas" produzem sínteses não-conceituais. O modelo musical da linguagem de Paulicéia desvairada não é, nesse sentido, a música de Rousseau, fundada na melodia e próxima da palavra, capaz de exprimir com relativa clareza os sentimentos do homem segundo as suas inflexões sucessivas ${ }^{445}$. A harmonia

\footnotetext{
${ }^{442}$ Idem. Ibidem, pp. 68-69.

443 Andrade, Mário de. "O movimento modernista", in Aspectos da literatura brasileira, op. cit., p. 258, grifo meu. Analogamente, escreveu Tristão de Athaíde que Paulicéia, "é profundamente brasileiro de sentimento, paulista, sobretudo, pecando até de regionalismo". Athaíde, Tristão de. "Vida literária" [1923], in Batista, Marta Rossetti; Lopez, Telê Porto Ancona; Lima, Yone Soares de (orgs.). Brasil: $1^{\circ}$ tempo modernista - 1917/29, op. cit., p. 202.
}

${ }^{444}$ Adorno, Theodor W. "Parataxe”, in Notes sur la littérature, op. cit., p. 331.

445 "A melodia faz precisamente na música o que o desenho faz na pintura", escreveu Rousseau, sobre a precisão representativa da melodia. Rousseau, Jean-Jacques. Essai sur l'origine des langues, Paris: Gallimard, 1990, p. 118. Para a concepção musical de Rousseau, ver as pp. 114-142. Ver também Idem. Dictionnaire de musique, Arles: Actes Sud, 2007, pp. 274-276, 305-317. 
marioandradina, ao contrário, procura transmitir impressões indeterminadas mediante a sobreposição de palavras ${ }^{446}$. Uma das principais vantagens do verso harmônico sobre o melódico, diz o poeta, é a capacidade de registrar simultaneidades, ou seja, de representar a coexistência de realidades múltiplas, em particular a coexistência de contrários $^{447}$. Mais do que isso, porém, o abandono das mediações sintáticas, na medida em que se vincula à noção de harmonia, possibilita articular misteriosamente os opostos em uma unidade. Com efeito, em sua origem, que remonta ao pensamento filosóficomusical pitagórico, depois retomado pelo platonismo, o conceito de harmonia significa antes de tudo a união de contrários, ou o vínculo obscuro por meio do qual os opostos perdem suas características específicas e se combinam ${ }^{448}$. A técnica marioandradina do verso harmônico procura justamente apreender e reproduzir as misteriosas mediações que articulavam, modificando-lhes o sentido próprio, os opostos aparentemente irredutíveis de uma cidade simultaneamente burguesa e pré-burguesa. Nos "acordes de palavras" de Paulicéia desvairada, os contrários se opõem e se fundem ao mesmo tempo:

$$
\begin{aligned}
& \text { “Marasmos... Estremeções..." } \\
& \text { “A engrenagem trepida... A bruma neva..." } 449
\end{aligned}
$$

A sintaxe, ou seja, o conjunto de mediações precisas de uma frase, é substituída pelas reticências, que sugerem a presença de mediações indiziveis: "as reticências revelam que ainda há algo a ser dito, $[\ldots]$ mas que este é inexprimível’"450. A linguagem reticente situa-se à beira do inefável. Para dizê-lo, a poesia de Paulicéia desvairada

\footnotetext{
446 No "Prefácio Interessantíssimo", Mário reconhece explicitamente o caráter em parte impressionista do livro: "Livro evidentemente impressionista. Ora, segundo os modernos, erro grave o Impressionismo". Andrade, Mário de. "Prefácio Interessantíssimo", in op. cit., p. 60.

${ }^{447}$ Andrade, Mário de. "Prefácio Interessantíssimo", in op. cit., p. 70.

448 Fubini, Enrico. L'estetica musicale dall'antichità al Settecento, Torino: Einaudi, 2002, pp. 18-23. Moutsopoulos, Evanghélos. La musique dans l'oeuvre de Platon, op. cit., pp. 332-340. Vale lembrar que, na Teogonia, Harmonia é filha de Ares, deus da guerra selvagem, e de Afrodite, deusa do amor. Ver Hesíodo. Teogonia: a origem dos deuses, São Paulo: Iluminuras, 2007, p. 153.

${ }^{449}$ Idem. Ibidem, pp. 96, 85, 94.

${ }^{450}$ Staiger, Emil. Conceitos fundamentais da Poética, Rio de Janeiro: Tempo Brasileiro, 1997, p. 71.
} 
pretende transfigurar-se em música, entre as artes a mais apropriada para dizer o que não pode ser dito, tendo em vista que é a mais abstrata entre elas ${ }^{451}$. No verso harmônico marioandradino, as reticências representam a liberação do significado e a passagem das palavras ao estado de ressonância. Volatilizadas na "suprema inconsistência" da música, os vocábulos tendem a fundir-se em uma espécie de nebulosa, em que se confundem as imagens, os conceitos e as sonoridades das palavras. A bruma, imagem mais constante de Paulicéia, é também um princípio formal do livro, por meio do qual o eu-lírico procura apreender e configurar as contradições irredutíveis da cidade ${ }^{452}$. Conforme dizem os versos de "Tristura", o batismo da filha - a poesia que o poeta teve com Paulicéia, sua "noiva", foi feito pelo "Sr. cura Bruma", com a “água-benta das garoas monótonas". Não raro, além das palavras no interior dos versos, os próprios versos - ou melhor, os ecos dos próprios versos - se confundem, de maneira que o poema inteiro constitui-se como bruma:

"São Paulo! Comoção de minha vida....

Os meus amores são flores feitas de original!...

Arlequinal!... Trajes de losangos... Cinza e ouro...

Luz e bruma... Forno e inverno morno...

Elegâncias sutis sem escândalos, sem ciúmes...

Perfumes de Paris... Arys!

Bofetadas líricas no Trianon... Algodoal!...

São Paulo! Comoção de minha vida...

Galicismo a berrar nos desertos da América." ${ }^{453}$

\footnotetext{
${ }^{451}$ Jankélévitch, Vladimir. La Musique et l'Ineffable, Paris: Seuil, 2002.

452 Victor Knoll assinala o "caráter brumoso" da poesia marioandradina em Paciente arlequinada, op. cit., p. 47.

${ }^{453}$ Andrade, Mário de. "Inspiração", in Paulicéia desvairada, in op. cit., p. 83.
} 
O conjunto sugere uma impalpável coincidência de contrários de toda sorte. Mediada pelas reticências, ou seja, pela bruma de palavras, a sobreposição de substantivos, adjetivos, verbos etc. deixa de ser abrupta e áspera, consumando-se suavemente em um contexto bastante "desmaterializado", etéreo. As dissonâncias se formam, mas lentamente e no âmbito rarefeito das vibrações, o que atenua sua estridência. Assim, ao mesmo tempo em que permite apreender dualismos que desafiam a expressão verbal, a técnica neblinosa do verso harmônico dilui as contradições implicadas nas ambivalências apreendidas. Adaptado em chave impressionistasimbolista, o princípio moderno da justaposição promove uma espécie de unio mystica das palavras, ao invés das rupturas que, no contexto do vanguardismo europeu, teve a função de produzir - a parataxe, escreveu Adorno, realiza um "atentado contra a harmonia" ${ }^{\prime 45}$. Em vez de expor, asperamente, as fendas do real, o verso harmônico desfaz em fumaça os antagonismos que o compõem. Por meio dessa composição vaporosa, Mário procura representar poeticamente uma matéria histórica em que os "caminhões" convivem com as "carroças", onde o moderno encontra-se atrelado ao antigo:

\footnotetext{
"Os caminhões rodando, as carroças rodando,

Rápidas as ruas se desenrolando,

Rumor surdo e rouco, estrépidos, estalidos....

E o largo coro de ouro das sacas de café!...." 455
}

Orquestrada pela modernização conservadora promovida pela prosperidade da economia cafeeira, a sinfonia da metrópole na periferia do capitalismo oferece desafios específicos ao escritor que a procura captar e transmitir, pois nela as dissonâncias são, ao mesmo tempo, consonâncias. Por meio do verso harmônico, Mário de Andrade procura representar essa "paisagem sonora" composta por timbres que não poderiam

\footnotetext{
${ }^{454}$ Adorno, Theodor W. "Parataxe", in Notes sur la littérature, op. cit., p. 340.

${ }^{455}$ Andrade, Mário de. "Paisagem no 4", in Paulicéia desvairada, in op. cit., p. 102.
} 
coexistir sem conflito, mas que em São Paulo não apenas se combinavam como se determinavam reciprocamente. Amortecida pelas reticências, a sobreposição de palavras não reproduz a experiência do choque, própria das grandes cidades no apogeu da civilização burguesa ${ }^{456}$, mas a dissolução das contradições na capital simultaneamente moderna e pré-moderna, "risco de aeroplano entre Mogi e Paris" ${ }^{457}$. Na medida em que constitui uma forma específica destinada a apreender uma matéria histórica peculiar, o princípio estrutural do verso harmônico é movido por um ânimo realista, apesar de sua tendência à abstração e à obscuridade - ou melhor, é justamente a tendência para o abstrato, para o obscuro e para a música que confere uma natureza realista às harmonias poéticas de Paulicéia, sendo este um dos paradoxos mais interessantes do livro.

Nessa linha, é preciso retificar a idéia, muito comum no âmbito da crítica marioandradina, de que Paulicéia desvairada registra a experiência do sujeito na cidade moderna. Com efeito, a modernidade vivenciada na São Paulo dos "frementes anos 1920" tem no livro feições bastante distintas da modernité, de que Baudelaire foi, nas palavras de Oehler, o "fenomenólogo e o analista" $"$. Ao perambular pelas ruas da capital paulista, o eu-lírico de Paulicéia desvairada encontra uma série de tipos sociais que compõem a imagem de uma cidade provinciana, apesar das pretensões cosmopolitas: o filho do imigrante nouveau-riche desfilando com seu automóvel, o vendedor de batatas do Cambuci berrando um pregão tradicional, o poeta modernista à procura de talentos, os deputados bajulando o governador, as costureirinhas que parecem bailarinas, as "rolas" da Escola Normal, o guarda-cívico prendendo um vagabundo, o mulato que toca violão na madrugada, o burguês que compra todos os perfumes de Paris, o fazendeiro que foge para a fazenda, assustado com a baixa do café, entre outros. Por si, muitas dessas personagens indicam uma cidade que está longe de ser uma metrópole moderna. Não obstante, particularizadas pelo poeta em seus traços distintivos, elas dão uma feição ainda mais local ao quadro urbano. Assim, se por um

\footnotetext{
456 Benjamin, Walter. "Sur quelques thèmes baudelairiens", in Charles Baudelaire: un poète lyrique à l'apogée du capitalisme, Paris: Payot, 1990, pp. 149-208.

${ }^{457}$ Andrade, Mário de. “Tu”, in Paulicéia desvairada, in op. cit., p. 98.

458 Oehler, Dolf. O Velho Mundo desce aos infernos, op. cit., p. 289. Benjamin, Walter. "A modernidade", in A modernidade e os modernos, Rio de Janeiro: Tempo Brasileiro, 2000, pp. 7-31.
} 
lado o retrato das variadas figuras sociais de São Paulo assinala o caráter cosmopolita da capital, registrando a diversidade de sua população, por outro a caracterização pitoresca dos "tipos da cidade" faz pensar em uma vila de província, pois nas massas das grandes cidades as diferenças entre os homens tendem a tornar-se indiscerníveis ${ }^{459}$.

No começo de seu ensaio sobre o flâneur, Benjamin assinala os limites estreitos - literários e ideológicos - das chamadas fisiologias, textos que procuravam caracterizar em forma de anedota os "curiosos" tipos da grande cidade. Essa literatura, que esteve na moda nos anos 1840 em Paris, escamoteava a nova - e inquietante - realidade das ruas das capitais do século XIX: as pessoas não podiam mais ser diferençadas facilmente umas das outras, sua aparência se tornara uniforme, sua profissão e seu caráter, indecifráveis à primeira vista. Com base nisso, Benjamin enfatiza a natureza ilusória do projeto de um folhetinista da época, que "pretendia poder analisar o público de Paris em seus estratos diferentes com a facilidade com que um geólogo distingue as camadas de uma rocha" ${ }^{460}$. A intenção do folhetinista não poderia realizar-se, diz o pensador alemão, pois o processo de generalização da forma mercadoria - de que a multidão urbana é um dos resultados -, ao completar-se, dera aos indivíduos a aparência de autômatos idênticos.

Em Paulicéia desvairada, a caracterização da população de São Paulo "em seus diferentes estratos" ainda é possível: a origem, a atividade profissional e a natureza

\footnotetext{
459 Analogamente, em Paulicéia desvairada, Mário procura localizar os poemas nas ruas e nos bairros de São Paulo, associando os tipos sociais a lugares específicos da cidade. Visto sob essa perspectiva, o livro tem algo de um conjunto de pitorescos cartões-postais paulistanos, nos quais se retratam as cenas quotidianas peculiares aos diferentes logradouros públicos da capital - Paulicéia, vale lembrar, contém quatro poemas que recebem o título de "Paisagem". Desse modo, surgem ao longo do livro, com as personagens correspondentes, o Trianon, a rua de São Bento, a Assembléia, o rio Tietê, a avenida São João, o Vale do Anhangabaú, o largo do Arouche, a igreja de Santa Cecília, os bairros operários (a Moóca, o Cambuci e o Bom Retiro), a Escola Normal, o bairro dos ricos (Higienópolis), Santa Efigênia, o Teatro Municipal, o Jardim América etc. A “iconografia topográfica” paulistana do livro de Mário de Andrade contrasta com a quase ausência de referências a lugares específicos de Paris n'As flores do mal. Quando Baudelaire menciona a Place du Carrousel, ele o faz justamente para deplorar a desaparição da antiga praça, assim como dos bairros, ruas e edifícios da velha Paris, demolida por Haussmann: "Le vieux Paris n'est plus (la forme d'une ville/ Change plus vite, hélas! que le coeur d'un mortel!)"388. A modernidade aparece sob o signo da precariedade, da modificação incessante, de tal maneira que, na capital moderna, o lugar característico deixa de existir; por sua vez, a poesia baudelairiana acompanha esse movimento de apagamento dos nomes dos locais da cidade. Assim, os cenários dos poemas dos "Quadros parisienses" são "a triste rua", "a rua ensurdecedora", "estes cais poeirentos", "os velhos subúrbios", enquanto a cidade é a "ville", a "cité" raramente nomeada.

460 Benjamin, Walter. "La Paris du Second Empire chez Baudelaire", in Charles Baudelaire: un poète lyrique à l'apogée du capitalisme, op. cit., p. 61.
} 
moral dos tipos sociais paulistanos podem ser identificadas à primeira vista. Nas calçadas paulistanas, o eu-lírico de Paulicéia desvairada não experimenta o choque em meio a multidões de seres idênticos, experiência decisiva da modernidade ${ }^{461}$. Ao contrário, há uma certa familiaridade no modo como o poeta se refere aos habitantes da cidade, com os quais estabelece, em alguns casos, conversas bastante informais. Não raro, os próprios "personagens de São Paulo" são flagrados pelo escritor em colóquios sem cerimônia, que assinalam a informalidade na esfera pública, própria do Brasil préburguês $^{462}$, valorizada pelos modernistas como atributo positivo da sociabilidade brasileira. Assim, no livro que inaugura nosso modernismo, as ruas de São Paulo são o lugar do diálogo pitoresco e não, como nas metrópoles modernas, o espaço em que se evidencia, em meio à multidão, o isolamento do indivíduo no apogeu da sociedade burguesa. Sob esse aspecto, apesar da linguagem parcialmente vanguardista, o livro é uma reunião de pequenas cenas de gênero, algo impensável em uma obra como $A s$ flores do mal, marcada pela "multidão inumerável onde ninguém é inteiramente decifrável para seu vizinho"463. Nos "Quadros parisienses", os seres que o eu-lírico entrevê nas ruas da fourmillante cité nunca falam, e um abismo os separa do poeta e os isola uns dos outros. Alguns são cegos como manequins, de modo que nada se lhes pode ler nos olhos "feitos de vazio e de trevas", outros são "sombras encarquilhadas", “espectros barrocos", e é sempre impossível saber de onde vêm e para onde vão. Na "multidão" paulistana, ao contrário, os indivíduos se cumprimentam com intimidade:

"Monotonias das minhas retinas...

Serpentinas de entes frementes a se desenrolar...

Todos os sempres das minhas visões! "Bon giorno, caro". 464

\footnotetext{
461 Para uma interpretação em sentido oposto, ver Bolle, Willi. "A cidade sem nenhum caráter: leitura de Paulicéia desvairada de Mário de Andrade”, in Revista Espaço \& Debates, n 27, São Paulo: Annablume, 1989, pp. 14-27.

462 Holanda, Sério Buarque de. Raízes do Brasil, São Paulo: Companhia das Letras, 2002, pp. 141-151.

463 Benjamin, Walter. "La Paris du Second Empire chez Baudelaire", in Charles Baudelaire: un poète lyrique à l'apogée du capitalisme, op. cit., p. 74.

${ }^{464}$ Andrade, Mário de. “Os cortejos”, in Paulicéia desvairada, in op. cit., p. 84.
} 
Nesse contexto "de paróquia", em que todos se reconhecem, o eu-lírico deve ocultar-se atrás de uma máscara para não ser notado:

"Ali em frente...

- Mário, põe a máscara!

- Tens razão, minha Loucura, tens razão.

O rei de Tule jogou a taça ao mar..." 465

Nas metrópoles modernas, ainda conforme os estudos de Benjamin, a multidão é justamente o que permite ao indivíduo percorrer incógnito as ruas da cidade, como se estivesse em seu apartamento: "a massa é o último asilo que protege o indivíduo antisocial de seus perseguidores" ${ }^{" 466}$. Nas ruas de Paulicéia, ao invés disso, o poeta modernista - o "desafinado", o "contrabandista"467 - precisa disfarçar-se, pois do contrário seria facilmente identificado. Como o rei da balada de Goethe, ele tem de resguardar, dos que estão à sua volta, seu bem mais íntimo: sua loucura, sua condição de transgressor das normas estéticas e morais da sociedade. As ruas de São Paulo em Paulicéia não são, portanto, como as ruas de Paris ou de Londres, o intérieur do "desajustado", mas o lugar onde este se encontra exposto. Enquanto as multidões das grandes cidades são o abrigo do criminoso, de sorte que nas metrópoles, segundo um relatório policial citado por Benjamin, "é quase impossível manter os bons costumes"468, em Paulicéia o infrator é encontrado sem demora:

\section{"Paisagem n" 1}

Minha Londres das neblinas finas...

\footnotetext{
465 Idem. "Paisagem no 2", in Paulicéia desvairada, in op. cit., p. 84.

466 Benjamin, Walter. "La Paris du Second Empire chez Baudelaire”, in op. cit., pp. 62-63.

${ }^{467}$ Andrade, Mário de. Paulicéia desvairada, in op. cit., pp. 73, 106.

${ }^{468}$ Idem. Ibidem, pp. 62-67.
} 
Pleno verão. Os dez milhões de rosas paulistanas.

Há neves de perfumes no ar.

Faz frio, muito frio...

$[\ldots]$

Passa um São Bobo, cantando, sob os plátanos

Um tralalá... A guarda-cívica! Prisão!

Necessidade a prisão

Para que haja civilização?" 469

Em seu quadro natural, descrito na primeira estrofe - o frio, a neblina, os plátanos -, São Paulo se assemelha a Londres, mas a cena retratada na segunda estrofe seria inverossímil na capital inglesa. A contravenção do passante de Paulicéia desvairada sequer seria notada, muito menos considerada perturbação da ordem pública, em meio ao barulho das ruas londrinas ${ }^{470}$, ou na rua ensurdecedora em que a célebre passante d'As flores do mal é entrevista. Na rua paulistana, porém, ouve-se com nitidez o "tralalá" da personagem, tal como somente o permitiria o silêncio das ruas semi-desertas... Assim como seu irmão parisiense, o "flâneur paulistano" caminha sob plátanos; diferentemente dele, no entanto, não caminha em meio às massas. Sensível à matéria histórica, a poesia de Paulicéia trai o programa modernista que a anima: "No palco de nosso século se representa essa ópera barulhentíssima a que Leigh Henry lembrou o nome: Men-in-the-street... Representemo-la"471. Em outras palavras, em "Paisagem no 1", assim como em outros poemas de Paulicéia desvairada, a intenção cosmopolita e atualizadora esbarra na notação localista, que a desautoriza ${ }^{472}$, configurando-se no poema um desacordo cheio de significado: no centro da paisagem

\footnotetext{
${ }^{469}$ Andrade, Mário de. "Paisagem no 1", in Paulicéia desvairada, in op. cit., p. 87, grifo meu.

${ }^{470}$ Benjamin, Walter. Passagens, Belo Horizonte: UFMG, 2007, p. 470.

${ }^{471}$ Andrade, Mário de. A escrava que não é Isaura, in op. cit., p. 224.

472 Conforme demonstrou Roberto Schwarz, uma equação parecida está na base das contradições formais do romance de José de Alencar. Ver Schwarz, Roberto. "A importação do romance e suas contradições em Alencar", in Ao vencedor as batatas, op. cit., pp. 35-79.
} 
"londrina" da metrópole que aspira à modernidade, assistimos a uma cena própria de uma cidade pré-moderna. A dissonância relativiza o progresso paulista, mas a despeito do eu-lírico, para quem o acontecimento é típico de uma sociedade burguesa:

\author{
"Necessidade a prisão \\ Para que haja civilização?”
}

A pergunta, considerando-se o contexto em que é feita, poderia ser traduzida por “o recalque, representado na repressão ao canto livre, é inerente à modernização?” e inclui uma segunda questão, desdobramento da primeira: "não seria possível combinar progresso e ausência de culpa?”. Nos anos seguintes à publicação de Paulicéia desvairada, a utopia de uma modernidade desrecalcada seria uma das bandeiras do nacionalismo modernista. A negação da ratio burguesa coincidiria com a valorização da informalidade característica das relações do familismo brasileiro, as quais deveriam estender-se ao espaço social, de modo a flexibilizar a dimensão normativa da esfera pública $^{473}$. O protesto contra as interdições - psíquicas e sociais - próprias da civilização burguesa teria como contrapartida a exaltação de formas de sociabilidade do Brasil pré-burguês: nosso atraso seria interpretado como vantagem, nossas deficiências, como superioridade ${ }^{474}$. A feição moderna desse ideário era dada em grande parte pela assimilação das vanguardas, as quais, na medida em que faziam a crítica da racionalização total da vida, aclimatavam-se com relativa facilidade ao programa dos

\footnotetext{
${ }^{473}$ Schwarz, Roberto. “Outra Capitu”, in Duas meninas, op. cit., p. 139.

${ }^{474}$ Candido, Antonio. "Literatura e cultura de 1900 a 1945", in Literatura e sociedade, op. cit., p. 120; Schwarz, Roberto. "A carroça, o bonde e o poeta modernista", in Que horas são?, op. cit., pp. 11-28. Entretanto, no caso de Mário de Andrade, conforme dito, as coisas não são simples assim. O núcleo do nacionalismo marioandradino é o seu pathos trágico e a adesão do escritor a formas sociais pré-burguesas envolve sempre, em alguma medida, a prática do sacrifício. Ao final de Macunaíma, como se sabe, o herói decide, em um gesto de recusa da modernidade, ir-se embora de São Paulo e regressar ao Uraricoera. Seu retorno ao mundo primitivo, contudo, configura-se como uma via crúcis e culmina com a auto-imolação de Macunaíma. Similarmente, o "Rito do irmão pequeno", por meio do qual o poeta nega os valores da civilização burguesa, constitui-se como uma agonia e resulta em uma espécie de semimorte. As obras nacionalistas de Mário, de modo geral, produzem "sínteses negativas", das quais o sacrifício é a principal. Vale lembrar, por fim, que o samba, talvez o gênero musical brasileiro por excelência, era considerado "trágico" por Mário de Andrade. Ver, do autor, "Música popular" [1939], in Música, doce música, op. cit., pp. 268-269.
} 
$\operatorname{modernistas}^{475}$. Por essa via, a estética do modernismo brasileiro entroncava-se na experiência da aristocracia cafeeira paulista, que esperava poder modernizar o país preservando a estrutura socioeconômica formada pela monocultura de exportação. Sem toda a coloração nativista que assumiria pouco depois ${ }^{476}$, o ideal de uma ordem moderna, mas sem recalque, já se encontra postulado no "desvairismo" proposto no "Prefácio Interessantíssimo", poética na qual convergem as exigências de alinhamento com a contemporaneidade e de libertação do inconsciente ${ }^{477}$.

Na medida em que a crítica da linguagem por ele representada não contém uma crítica da sociedade à mesma altura, o clamor libertário do "desvairismo" contra as restrições impostas à criação poética pelas regras do parnasianismo assemelha-se, em certo grau, ao empenho com que a oligarquia de São Paulo, sempre tendo em vista a expansão de sua liberdade no campo econômico, apoiara a abolição da escravatura e a consolidação do regime republicano, mas sem exigir que essas transformações institucionais resultassem na expansão da cidadania. Lembremos ainda uma vez: "Os meus suspiros muito louros/ Entreteceram-se com a rama dos cafezais" ${ }^{\prime 478}$. Exigência de uma liberdade sem qualquer compromisso, o grito de laissez faire! dado em Paulicéia tem muito da "negação pura e simples de uma autoridade incômoda", a que se refere Sérgio Buarque de Holanda, própria do modo superficial e parcial como nossas elites, nos momentos em que promoveram o "rompimento" com a velha ordem, assumiram historicamente os princípios do liberalismo democrático, de forma que estes se

\footnotetext{
475 Sobre a natureza irracional das relações sociais forjadas no ambiente da família patriarcal brasileira, ver Holanda, Sérgio Buarque de. Raizes do Brasil, op. cit., pp. 141-151; Schwarz, Roberto. "As idéias fora do lugar", in Ao vencedor as batatas, op. cit., pp. 11-31.

476 Já em Paulicéia, não obstante, encontram-se prenúncios do nacionalismo posterior de Mário de Andrade: em "Anhangabaú", o poeta lamenta a falta de bananeiras nos jardins do centro de São Paulo, afrancesados por demais; em "O domador", propõe em tom de sátira uma letra nativista para o hino nacional; no "Prefácio Interessantíssimo", defende o "falar brasileiro", assim como deplora, em "O trovador", a condição de autótoctone obrigado a cantar em língua européia. Finalmente, no oratório "As Enfibraturas do Ipiranga", que fecha o livro, a reivindicação nacionalista se torna explícita e dominante,

477 Passada a fase de combate à estética tradicional e de atualização da cultura do país com base nos parâmetros da arte européia, fase de que a publicação de Paulicéia desvairada é provavelmente o momento mais marcante, Mário assumiria um ponto de vista cada vez mais crítico em relação à racionalização e à alienação que o progresso impõe ao mundo. Essa recusa dos valores modernos por parte do autor é dramatizada no "Rito do irmão pequeno" [1931], importante poema de Livro azul. Andrade, Mário de. Poesias completas, op. cit., pp. 331-335.
}

${ }^{478}$ Idem. "As enfribaturas do Ipiranga", in Paulicéia desvairada, in op. cit., p. 109. 
acomodassem aos velhos privilégios que tinham sido, no Velho Mundo, o alvo do combate da burguesia contra os aristocratas ${ }^{479}$. No fim da vida, como é sabido, Mário de Andrade criticaria o vínculo do modernismo com a elite cafeeira paulista, assim como a natureza aristocrática do movimento, decorrente da combinação, segundo o escritor, de "internacionalismo modernista", "nacionalismo embrabecido", "dogmatismo prepotente" e "gratuidade antipopular", entre outras coisas ${ }^{480}$ - características que também definiam a experiência da aristocracia do café, e que se encontram, em maior ou menor medida, no coração da poética "desvairista" marioandradina. Ao leitor provavelmente não passará despercebido o teor elitista do desdém que o poeta manifesta acerca das possibilidades de compreensão de sua "nova poesia": "Canto da minha maneira. Que me importa si me não entendem? [...] Novo Anfião moreno e caixad'óculos, farei que as próprias pedras se reunam em muralhas à magia do meu cantar. E dentro dessas muralhas esconderemos a nossa tribo"481. Nesse contexto, possui uma insuspeitada ressonância conservadora a epígrafe libertária do "Prefácio Interessantíssimo", extraída de um poema de Verhaeren: "Dans mon pays de fiel et d'or j’en suis la loi". O verso proclama a "ditadura do imaginário" característica de uma vertente da poesia moderna, defendendo a liberdade criativa absoluta do eu, por meio da qual a subjetividade, na esfera simbólica, se desagrava das alienações do mundo moderno ${ }^{482}$. Colocada na abertura do "manifesto" marioandradino, a frase sintetiza a negação, que o "Prefácio" e os poemas de Paulicéia procuram levar a cabo, das rígidas

\footnotetext{
479 Holanda, Sérgio Buarque de. Raízes do Brasil, op. cit., p. 160. Ver também Costa, Emília Viotti da "Liberalismo: teoria e prática", in Da Monarquia à República: momentos decisivos, São Paulo: Unesp, 1999, pp. 131-168. Na Independência, a defesa das idéias liberais praticamente se restringira à exigência de emancipação dos estamentos senhoriais das limitações oriundas do estatuto colonial, ou seja, à demanda de internalização dos centros de poder, que passariam a ser controlados pelas classes dominantes locais, sem alteração substancial da estrutura socioeconômica do país. A República, por sua vez, inspirada na retórica da Revolução Francesa, não representara muito mais do que o afastamento da Coroa, que durante o Império conservara para si o primado das decisões políticas fundamentais, e a consolidação do poder incontrastável das oligarquias estaduais, em particular o da oligarquia paulista: "Não vindo acompanhadas por expansão significativa da cidadania política, [as mudanças trazidas pela República] resultaram em entregar o governo mais diretamente nas mãos dos setores dominantes, tanto rurais quanto urbanos. O Império tornara-se um empecilho ao dinamismo destes setores, sobretudo os de São Paulo". Carvalho, José Murilo de. Os bestializados: o Rio de Janeiro e a República que não foi, São Paulo: Companhia das Letras, 2008, pp. 45-46.

${ }^{480}$ Andrade, Mário de. “O movimento modernista”, in Aspectos da literatura brasileira, op. cit., p. 259.

${ }^{481}$ Idem. "Prefácio Interessantíssimo", in Paulicéia desvairada, in op. cit., pp. 75-76.

${ }^{482}$ Friedrich, Hugo. Structure de la poésie moderne, op. cit., 2004, pp. 112-116.
} 
regras parnasianas de composição poética, as quais imperavam no ambiente literário brasileiro da época. Não obstante, considerando-se que a exigência de liberação artística não corresponde, no livro, a uma exigência de liberação social, a epígrafe do "Prefácio Interessantíssimo" parece também traduzir a experiência concreta de uma classe que se apropriara do Estado e o pusera a serviço de seus interesses próprios, de maneira que, encontrando-se no auge de seu poderio polítco-econômico quando Paulicéia foi escrita, podia declarar com confiança: l'État, c'est moi. Não é à toa que o vanguardismo do livro de Mário de Andrade, longe de ser radical, combina-se em Paulicéia com certo tradicionalismo literário, inclusive com o aproveitamento de formas parnasianas e, em especial, simbolistas.

À coexistência de modernidade e tradição no plano das formas literárias corresponde uma convivência semelhante no travejamento ideológico de Paulicéia. Olhando bem, a figura do São Bobo, de "Paisagem n ${ }^{\circ}$ 1", tem afinidades com o poeta modernista, ou pelo menos com a imagem que este procurava passar de si mesmo no livro: o artista santo e louco perseguido pelas forças da ordem por cantar com liberdade ${ }^{483}$. A mesma irreverência, entretanto, não a demonstra o eu-lírico em "Noturno", poema que tem como matriz o "Crépuscule du soir" dos Tableaux parisiens, de Baudelaire. Assim como no modelo francês, nos versos marioandradinos a noite é o momento do crime, particularmente da prostituição, e sua atmosfera é carregada de demônios ${ }^{484}$. Mário assimila da composição baudelairiana a representação da sexualidade irreprimida e criminosa nas ruas obscuras da cidade. Articulado a uma plataforma de libertação e combate, ou seja, de negação das instituições sociais, o tratamento não-convencional do sexo em As flores do mal já estivera na base da “importação" da poesia de Baudelaire por parte de um grupo de poetas realistas durante a década de 1870 , conforme demonstrou Antonio Candido ${ }^{485}$. Por sua vez, a partir dos

\footnotetext{
483 Para Lafetá, em sentido análogo, o São Bobo "é talvez uma boa e irônica alegoria da 'loucura' modernista". Lafetá, João Luiz. "A representação do sujeito lírico na Paulicéia desvairada", in op. cit., p. 369.

${ }^{484}$ A matriz baudelairiana do poema de Mário foi notada por Telê Porto Ancona Lopez em “Arlequim e modernidade", in Lopez, Telê Porto Ancona. Mariodeandradiando, op. cit., p. 28.

485 Candido, Antonio. "Os primeiros baudelairianos", in A educação pela noite \& outros ensaios, São Paulo: Ática, 2000, pp. 23-38.
} 
anos 1880, "nossos corretos parnasianos", na expressão do crítico, abafaram essas ousadias e optaram, entre as influências européias, pelo reacionarismo de Leconte de Lisle. O autor d'As flores do mal tornara-se, entre os escritores brasileiros, sinônimo de revolta e desmistificação. Nesse contexto, é natural que em Paulicéia desvairada, livro que foi escrito e publicado com a finalidade explícita de promover agressivamente a contestação dos valores tradicionais e a renovação da cultura nacional, recuperasse Baudelaire, o poeta maldito.

Em "Noturno", contudo, onde a inspiração baudelairiana é explícita - as prostitutas são metaforicamente nomeadas "flores do mal" -, Mário de Andrade é surpreendentemente tímido para os padrões de um iconoclasta: ao contrário do autor de "Crépuscule du soir", o eu-lírico de Paulicéia evita a todo custo chamar a prostituição pelo nome, de modo que o poema, na contramão das intenções de causar escândalo próprias do livro, é encoberto por uma atmosfera de decoro, à qual corresponde a bruma que turva a imagem dos crimes que se praticam à noite nas ruas do Cambuci. O pudor em relação à prostituição liga-se decerto ao conhecido peso da formação católica em Mário, formação que o poeta reafirma, como se pedisse perdão pelas ousadias literárias e morais contidas em Paulicéia, no penúltimo poema do livro, "Religião", uma inflamada profissão de fé no catolicismo - "em verso também se peca”, adverte Carlos, em carta de 1914 ao irmão Mário de Andrade ${ }^{486}$. Nisso, o "Noturno" de Paulicéia antecipa o "Canto do mal de amor", de 1924, onde o conflito entre sexualidade e repressão moral durante a caminhada noturna assume uma feição dramática exacerbada ${ }^{487}$. Não obstante, o recato do escritor em "Noturno" tem também um significado histórico-social e aponta para as relações pessoais e sobretudo ideológicas dos modernistas com a aristocracia cafeeira paulista, comentadas acima.

\footnotetext{
486 "Por que [...] não serás, poeta, o mesmo católico que és de convicção? [...] Em verso também se peca". Carta de Carlos de Moraes Andrade a Mário de Andrade, 12 de fevereiro de 1914. Arquivo MA, IEBUSP.

487 Uma interpretação do poema é feita por João Luiz Lafetá em Figuração da intimidade, op. cit., pp. $38-46$.
} 
Como disse Benjamin, "quanto mais o trabalho se aproxima da prostituição, mais tentador torna-se qualificar a prostituição como um trabalho" 488 . À vista disso, a distância que o eu-lírico marioandradino toma em relação à prostituição significa não apenas uma timidez cristã, mas também uma recusa dolorosa da forma mercadoria dolorosa, pois o mundo da mercadoria aparece no poema como tentador. Mário recua diante da mercantilização da força de trabalho em seu grau mais degradante, embora revele certo desejo secreto e fervoroso de participar do mercado do amor. A ambivalência do poeta modernista a respeito da prostituição lembra a duplicidade própria da condição histórica da oligarquia cafeeira paulista no apogeu da República Velha: por um lado, uma classe ciosa de sua natureza aristocrática e de sua nacionalidade ${ }^{489}$, portanto de seu caráter genuíno e de sua diferença em relação à tosca burguesia emergente de São Paulo, composta em grande parte por imigrantes; por outro lado, uma aristocracia cuja eminência baseava-se na venda de um produto primário para o exterior e que procurava assimilar as novidades ideológicas e materiais do mundo burguês. Paris, a capital mundial do fetichismo da mercadoria ${ }^{490}$, não fascinava apenas, entre as elites paulistas, o burguês ridículo satirizado em Paulicéia desvairada - "Tenho todos os perfumes de Paris!", diz o burguês do poema "Colloque sentimental" -, mas também a fração intelectualizada e refinada da oligarquia, obcecada por formas requintadas de consumo ${ }^{491}$.

Mário de Andrade, ao contrário de Oswald, não pertencia às elites paulistas, sendo uma espécie de "primo pobre" entre os modernistas, o que torna mais complexas as relações entre sua poesia e a ambivalente experiência ideológica daquela classe em relação à generalização da forma mercadoria. Não obstante, no início dos anos 1920,

\footnotetext{
${ }^{488}$ Benjamin, Walter. Passagens, op. cit., p. 406.

489 "Sejamos agora de novo, no cumprimento de uma missão étnica e protetora, jacobinamente brasileiros". Prado, Paulo. "Poesia Pau-Brasil", in Andrade, Oswald de. Poesias reunidas, Rio de Janeiro: Civilização Brasileira, 1974, p. 69. Nesse texto, Paulo Prado faz questão de distinguir-se dos "novos-ricos da Arte", assim como dos "empregados públicos da literatura, Acadêmicos de fardão, Gênios das províncias, Poetas do 'Diário Oficial"', colocando-se desse modo como representante de uma aristocracia cosmopolita, moderna e liberal, que apóia a nova e legítima arte brasileira.

490 Benjamin, Walter. "Paris, capitale du XIX" siècle”, in Écrits français, op. cit., pp. 374-400.

491 Miceli, Sérgio. "Intelectuais e classe dirigente no Brasil (1920-1945)”, in Intelectuais à brasileira, op. cit., pp. 103-104.
} 
quando publicou Paulicéia desvairada, Mário fazia parte, inclusive como uma de suas principais figuras, do círculo intelectual patrocinado pelos "Prados e Penteados e Amarais", conforme ele recorda na célebre conferência de 1942 sobre o movimento modernista ${ }^{492}$. De fato, Oswald de Andrade, "apresentando" o autor de Paulicéia desvairada ao público paulistano em um artigo de 1921, ressalta a "aristocrática alma íntima" de Mário, talvez procurando minimizar a importância de diferenças socioeconômicas, que pareceriam insignificantes ao lado das "afinidades eletivas espirituais" existentes entre o poeta de classe média e os círculos abastados freqüentados pelos "novos de São Paulo"493.

Embora tivesse consciência lancinante de sua posição social e evitasse a todo custo as situações humilhantes que seu convívio com a oligarquia freqüentemente criava, o próprio Mário jamais deixou de referir-se a si mesmo como a um "aristocrata do espírito", como vimos anteriormente. Em Paulicéia desvairada, ele procura fazer "poesia citadina", como disse Oswald, ou seja, poesia moderna sobre a cidade moderna, porém salvaguardando a pureza de seu lirismo, esse "estado afetivo sublime", análogo à "sacra fúria"494. A crítica da reificação burguesa empreendida no livro confunde-se, portanto, com a valorização de aspectos do mundo pré-burguês, tais como a "sagrada reverência da exaltação devota", que a burguesia, segundo Marx, "afogou nas águas geladas do cálculo egoísta", mas que era, ela mesma, um índice da exploração social “encoberta com ilusões religiosas" 495 . Assim como a "nobreza regional" que o apóia, Mário de Andrade quer assimilar a modernidade sem perder sua aura, sua genuinidade. Entre outras coisas, o "Prefácio Interessantíssimo" é uma autêntica profissão de fé do lirismo genuíno, antípoda da muse vénale de Baudelaire, à qual se dirigem os versos seguintes d'As flores do mal:

\footnotetext{
492 Andrade, Mário de. "O movimento modernista”, in Aspectos da literatura brasileira, op. cit., pp. 253-280.

493 Andrade, Oswald de. "O meu poeta futurista" [1921], in Brasil: 1' tempo modernista - 1917/29, op. cit., pp. 183-187.

494 Andrade, Mário de. "Prefácio Interessantíssimo", in Paulicéia desvairada, in op. cit., p. 72. Idem. A escrava que não é Isaura, in Obra imatura, Belo Horizonte: Itatiaia, 1980, p. 224.

495 Ver, por exemplo, o poema "Religião". A citação de Marx encontra-se em Marx, Karl; Engels, Friedrich. Manifesto do partido comunista, in Obras escolhidas - I, op. cit., 109.
} 
"Il te faut, pour gagner ton pain de chaque soir,

Comme un enfant de choeur, jouer de l'encensoir,

Chanter des Te Deum auxquels tu ne crois guère." 496

Ao longo de sua obra, Baudelaire comparou diversas vezes o escritor à prostituta $^{497}$. Nos Pequenos poemas em prosa, por exemplo, ele se refere à "santa prostituição da alma que se entrega inteira [...] ao desconhecido que passa" ${ }^{\circledR 498}$. Com ironia e sem ilusão, percebia - e a assumia para melhor criticá-la ${ }^{499}$ - a degradante situação do escritor e da literatura na sociedade burguesa: "Por mais bela que seja uma casa, ela é antes de tudo - antes que sua beleza fique demonstrada - tantos metros de altura por tantos metros de largura. - Da mesma maneira a literatura, a matéria mais inapreciável, - é antes de mais nada uma série de colunas; e o arquiteto literário, cujo nome apenas não é uma probabilidade de benefício, deve vender a qualquer preço" ${ }^{\circ 00}$. O desencantamento que marca a posição de Baudelaire a respeito da situação do escritor na modernidade relaciona-se essencialmente à compreensão da generalização da forma mercadoria na sociedade parisiense do século XIX. No "Crépuscule du soir", a prostituição está em toda parte da cidade, e os demônios noturnos que povoam a atmosfera da capital francesa são "como homens de negócios". A mercantilização da produção literária é parte desse quadro histórico-social, no qual todas as atividades humanas se encontram submetidas ao regime de compra-e-venda, ou à "prostituição

\footnotetext{
${ }^{496}$ Baudelaire, Charles. "La muse vénale", in Les fleurs du mal, vIII. Op. cit., p. 11.

497 Benjamin, Walter. "La Paris du Second Empire chez Baudelaire", in Charles Baudelaire: un poète lyrique à l'apogée du capitalisme, op. cit., pp. 48-54.

498 Baudelaire, Charles. Petits poèmes en prose, XII, "Les foules”, in Oeuvres complètes, op. cit., p. 170.

499 "Embora se oponha à sociedade, [a arte] não é contudo capaz de obter um ponto de vista que lhe seja exterior; somente consegue opor-se ao identificar-se com aquilo contra que se insurje". Theodor W. Adorno, Teoria Estética, op. cit., p. 155.

${ }^{500}$ Baudelaire, Charles. "Conseils aux jeunes littérateurs. Des salaires”, in op. cit., p. 318 . O autor d'As flores do mal, todavia, nunca fez "sucesso" no mercado literário de sua época, muito pelo contrário. Afinal, sua obra constitui uma crítica radical do mundo da mercadoria, cujas leis ela assimila apenas na medida em que, desse modo, pode combatê-lo de frente, em um movimento dialético de negação determinada, e não de negação abstrata.
} 
geral”, como escreveu Marx ${ }^{501}$. Enquanto um mercado de literatura bastante lucrativo já se havia consolidado na Paris baudelairiana, a situação era muito distinta na São Paulo dos anos 1920, especialmente no que dizia respeito às obras do modernismo, as quais "se destinavam a um círculo bastante reduzido de iniciados, pertencentes às famílias abastadas da oligarquia local, e que detinham as chaves para decifrar tais obras ${ }^{\prime 502}$. As edições dos livros modernistas eram "empreendimentos editoriais financiados pelos próprios autores ou por seus mecenas, e ostentavam as características de uma produção artesanal de luxo"503. Encontravam-se, desse modo, virtualmente excluídas do mercado mais amplo, em si mesmo incipiente e restrito.

No "Noturno" de Paulicéia desvairada, o recuo do eu-lírico diante da prostituição tem a marca de uma sociedade em que ainda é possível, para um grupo de privilegiados, ter a ilusão de levar uma vida imune à degradação inerente às relações comerciais. Assim, a prática da prostituição restringe-se, no poema de Mário, aos limites de um bairro de São Paulo - justamente um bairro operário, o Cambuci -, ao contrário do que ocorre no "Crépuscule du soir", onde ela se espalha por toda a cidade. Na mesma linha, assim como no modelo baudelairiano, também no "Noturno" marioandradino “diabos andam no ar", mas nos versos do poeta paulistano os demônios não são comparados a negociantes, apenas carregam "corpos de nuas" - ou seja, enquanto em Baudelaire a prostituição é apresentada como um dos fenômenos por excelência da decomposição da vida social no apogeu do capitalismo, em Mário ela é considerada segundo uma perspectiva moralista: as prostitutas são nomeadas "flores do mal".

A recusa do mercado do amor no "Noturno", todavia, é contraditória e dolorosa, tal como costuma ser a negação do mundo da mercadoria na obra de Mário. O regresso de Macunaíma ao universo mítico do Uraricoera, por exemplo, não se dá como volta

\footnotetext{
${ }^{501}$ Marx, Karl. Elementos fundamentales para la crítica de la economía política (Grundrisse) 1857-1858, I, México: Siglo Veintiuno, 2007, p. 90.

502 Miceli, Sérgio. "Intelectuais e classe dirigente no Brasil (1920-1945)", in Intelectuais à brasileira, op. cit., p. 97.

${ }^{503}$ Idem, ibidem.
} 
triunfal; ao contrário, assemelha-se a uma via-crúcis ${ }^{504}$ e culmina na auto-imolação do herói. No "Rito do irmão pequeno", onde a renúncia da civilização burguesa assume a feição de um programa, o eu-lírico convida o leitor para o exercício de uma autêntica agonia ritualística, para um conjunto de práticas sacrificiais. Diferentemente do que se costuma dizer, portanto, a negação dos valores da sociedade burguesa, que no ideário modernista significa a recusa da existência à européia, não reverte, na literatura marioandradina, na afirmação positiva do caráter nacional. Este se manifesta sob forma de crise, no sentido forte do termo, ou seja, como traspasse, como passagem para a morte. Está em jogo, nesse caso, a conhecida dialética brasileira entre o não-ser e o ser outro, formulada por Paulo Emílio Salles Gomes: "não somos europeus nem americanos do norte, mas destituídos de cultura original, nada nos é estrangeiro, pois tudo o é. A penosa construção de nós mesmos se desenvolve na dialética rarefeita entre o não ser e o ser outro"505. Em Mário, pode-se dizer que essa dialética assume feição penosíssima, dramática e negativa. Em sua vertiginosa negatividade, a obra do autor de Macunaíma diferencia-se do progressismo conservador e otimista da aristocracia cafeeira. No "Noturno", o recuo diante da mulher-mercadoria não se dá sem sofrimento e tem algo do "medo do amor" que Mário estudou nos poetas românticos brasileiros"506: o eu-lírico reprime seus instintos sexuais e não rompe as "grades em girândolas de jasmins", sua pureza, sua intimidade incorruptível, como faria uma cela monástica, mas que exasperam, intoxicando a atmosfera com os perfumes do desejo, as contradições entre o magnetismo exercido pela mercadoria e as suscetibilidades católicas e "aristocráticas"

\footnotetext{
504 Como notou a professora Maria Augusta Fonseca em texto ainda inédito, que ela gentilmente me permitiu ler e citar.

${ }^{505}$ Apud Arantes, Paulo Eduardo. Sentimento da dialética na experiência intelectual brasileira, op. cit., p. 15.

506 Andrade, Mário de. "Amor e medo", in Aspectos da literatura brasileira, op. cit., pp. 221-252. Sobre o medo do amor dos nossos escritores românticos, escreveu Mário, em palavras que valem, em alguma medida, para sua obra: "Não tem dúvida nenhuma que um dos mais terríveis fantasmas que perseguem o rapaz é o medo do amor, principalmente entendido como realização sexual. Causa de noites de insônia, de misticismos ferozes que depois de vencidos se substituem por irreligiosidades igualmente ferozes e falsas; causa de fugas, de idealizações inócuas, de vícios, de prolongamentos e infantilismo, de neurastenia, o medo do amor toma variadíssimos aspectos. No geral poucos o denunciam claro, guardam-no no segredo de si mesmos, porque o mundo caçoa disso, converte o medo do amor numa inferioridade fisiológica risível. Mas na verdade as suas causas ora são puramente históricas, provenientes de educação, de convívios; ora são temperamentais, provenientes da nossa psicologia, da nossa fisiologia, da nossa sensibilidade e suas delicadezas e respeitos". Idem. Ibidem, p. 222.
} 
do poeta: "E meu céu é todo um rojão de lágrimas!...". Ao lado da ousadia baudelairiana, a timidez cristã do eu-lírico marioandradino produz uma penosa impressão de provincianismo, de modernidade diminuída. Algo como um "tamanho paulista" se revela no poema, nessa configuração de satanismo no Cambuci, a indicar um descompasso a que a combinação de técnica vanguardista e grandiloqüência tradicional corresponde no plano da linguagem.

O princípio formal do verso harmônico, conforme dito, procura integrar essa matéria artística social e individual desconjuntada, que constitui um desafio à própria elaboração de uma lírica moderna. Por meio das harmonias de palavras, Mário de Andrade aspira a unir, em poesia, os contrários que misteriosamente se combinavam na realidade paulistana: as multidões e a familiaridade, a prostituição satânica e o carolismo, o gosto da mercadoria e a suscetibilidade aristocrática, a celebração da modernidade e a nostalgia do passado pré-moderno, o tupi e o alaúde, a uiara e a Bolsa de Valores, o asfalto e a lama, a República e o espírito de corte, as "romas de Petrônio" e o leito virginal, entre outros pares de opostos que o poeta encontra, em São Paulo, sob a forma de estranhas associações. Nesse sentido, a bruma de vocábulos mistifica e esclarece ao mesmo tempo. Nela, a cidade se dá a ver... ocultando-se. No movimento mesmo em que se torna obscura por meio da poesia, Paulicéia se revela. A bruma obscurece o real, mas é somente por meio dela, ou melhor, é somente nela que o real se torna visível. É claro que a visão, nessas circunstâncias, não é uma visão por assim dizer mais "apolínea", distanciada, com a qual opera, por exemplo, a poesia de Oswald de Andrade $^{507}$. Ela tem algo da visão dos místicos, de uma docta ignorantia, na qual coincidem a mais indevassável obscuridade e a mais lúcida clarividência ${ }^{508}$ : "Mas à chuva dos rosais/O êxtase fará sempre Sol!", dizem os versos da conhecida "Ode ao burguês"509.

\footnotetext{
507 Schwarz, Roberto. "A carroça, o bonde e o poeta modernista", in Que horas são?, op. cit., pp. 17-19. Ver, também, as primeiras páginas do ensaio "Uma poética da radicalidade", de Haroldo de Campos, in Andrade, Oswald de. Pau-Brasil, op. cit., pp. 7-27. Nessas páginas, o crítico assinala as diferenças entre a "lirismo objetivo e antiilusionista" de Oswald e o "mal da eloqüência" parnaso-simbolista em Mário de Andrade.

${ }^{508}$ Bastide, Roger. Les problèmes de la vie mystique, op. cit., pp. 68-69.

${ }^{509}$ Andrade, Mário de. Paulicéia desvairada, in op. cit., p. 88, grifos meus.
} 
Em Paulicéia desvairada, o conhecimento da realidade, impossível de traduzir para a linguagem discursiva, ocorre sob a forma de fulgurações em meio à turvação: "De repente/ Um raio de Sol arisco/ Risca o chuvisco ao meio" 510 . Nesse quadro, as visões da cidade têm a natureza de alucinações visuais e sonoras, características também do êxtase místico, em particular do êxtase cristão ${ }^{511}$ - dirigindo-se a São Paulo, escreve o poeta: "E serás sempre, morrente chama esgalga/ Meio fidalga, meio barregã,/As alucinações crucificantes/ De todas as auroras do meu jardim!" rebanho", por exemplo, o eu-lírico vê os deputados paulistas transformarem-se em cabras e irem pastar, docilmente, nas proximidades do Palácio do Governo. De modo semelhante, em "Os cortejos", os homens da cidade assemelham-se a macacos, quando postos sob os "olhos ricos" do escritor. Nos dois casos, as transformações são como momentos de verdade, ou seja, nelas vem à tona o significado profundo da realidade, que se encontrava oculto sob as aparências. A lucidez, nesse contexto, advém no instante do "eclipse da razão" - a loucura, de fato, é uma espécie de ponto de vista da obra, como forma privilegiada de conhecimento do sujeito lírico e da cidade ${ }^{513}$.

De acordo com esse regime contraditório, quanto mais densas as trevas, mais claras as luzes: “A noite é toda um véu-de-noiva ao luar!”, exclama o eu-lírico no poema "Colloque sentimental" 514 , sintetizando na dúplice imagem a "dialética" de opacidade e transparência própria de Paulicéia desvairada - dialética singular, em que a "síntese" se produz quando os contrários entram em uma espécie de curto-circuito, e não quando se dá, entre eles, uma síntese superior. No livro de estréia do modernismo brasileiro, os esforços de apreensão da matéria histórica encontram sua consumação na "treva cor de cal" ${ }^{15}$, em uma espécie de noite radiante, própria dos cultos de mistério e

\footnotetext{
${ }^{510}$ Idem. "Paisagem no 3", in Paulicéia desvairada, in op. cit., p. 99.

511 Rouget, Gilbert. La musique et la transe, Paris: Gallimard, 2004, pp. 51-52.

512 Andrade, Mário de. "Tu”, in Paulicéia desvairada, in op. cit., p. 98.

513 Lopez, Telê Porto Ancona. Mariodeandradiando, op. cit., pp. 19-27. No "Prefácio Interessantíssimo", Mário de Andrade postula a existência de uma "ordem imprevista" nas livres associações de imagens, "uma ordem inda mais alta" que a das frases organizadas segundo as regras da sintaxe. Andrade, Mário de. "Prefácio Interessantíssimo", in op. cit., pp. 66-67.
}

${ }^{514}$ Idem. "Coloque sentimental", ibidem, p. 99.

515 Idem. "Noturno", ibidem, p. 95. 
do misticismo medieval ${ }^{516}$. Trata-se, em última instância, de obter a visão na morte: de acordo com os versos finais de Paulicéia, o sacrifício dos modernistas, em que se consuma a missão de fazer a cultura brasileira voltar seus olhos para o próprio país, será resgatado "no luto em luz,/ das praias sem borrascas" 517.

Na lírica de Mário de Andrade, a imagem do esplendor noturno reaparece no final do "Noturno de Belo Horizonte" [1924], no momento paroxístico das alucinações do eu-lírico, alucinações que procuram "reunir os Brasis", e das quais a fulguração na noite é uma síntese negativa e efêmera:

"O Sol explode em fogaréus...

O dia é frio sem nuvens, de brilhos vidrilhos...

Não é dia! Não tem Sol explodindo no céu!

É o delírio noturno de Belo Horizonte..." 518

Cinco anos mais tarde, nos "Poemas da negra", que relatam a experiência de um êxtase amoroso em atmosfera nativista, o eu-lírico se transfigura em luz à medida que se dissolve na "escureza suave" do corpo da amada. Representado em chiaroscuro intimista, o fenômeno da noite rútila aparece como a culminação de certo erotismo ritualístico, recebendo uma inequívoca marca religiosa ${ }^{519}$. Por fim, de modo solene e dramático, o tema da fulguração noturna encontra-se no coração da grandiosa "Meditação sobre o Tietê", onde ele se configura na plenitude de sua significação, essencialmente relacionado ao esforço desesperado de compreensão da matéria histórica brasileira, em particular da versão paulista desta. No momento de maior adensamento da noite, quando as águas do rio se tornam espessas e negras, carregadas das sombras soturnas que se expandem por todos os lados, “o rio esplende em luzes inumeráveis", de

\footnotetext{
516 Sobre a paradoxal simbologia da noite utilizada pelo misticismo cristão, ver os comentários de Leo Spitzer sobre o poema "Em uma noite escura", de San Juan de la Cruz, in Spitzer, Leo. Três poemas sobre o êxtase, São Paulo: CosacNaify, 2003, pp. 56-82.

${ }^{517}$ Andrade, Mário de. “As enfibraturas do Ipiranga”, in Paulicéia desvairada, in op. cit., p. 114.

${ }^{518}$ Idem. "Noturno de Belo Horizonte", in Clã do jabuti, in Poesias completas, op. cit., 189.

${ }^{519}$ Idem. "Poemas da negra", in Remate de males, in Poesias completas, op. cit., pp. 247-252.
} 
modo que, por um instante, nele brilha a imagem de São Paulo, com seus arranha-céus, palácios e ruas, com seus habitantes transformados em dinossauros, "bichos blau" e gatos verdes... Por um momento, a cidade fulgura em sua verdade ${ }^{520}$.

A figura oximoresca da escuridão resplandecente traduz uma experiência que muitos dos poemas mais importantes de Mário de Andrade, pelo menos desde Paulicéia desvairada, reproduzem em sua própria fatura: a obscuridade, levada ao limite de si mesma, converte-se em revelação. O paradoxo chegou a ser formulado por Mário em um ensaio de 1940: “A Poesia obscura, por qualquer razão, estética ou técnica, difícil de se compreender, deve ter seus limites. É possível a gente aceitar, e eu aceito, as obscuridades ilimitáveis, mas com risco de me tornar eu mesmo obscuro, reconheço que esta indelimitação terá de ser sempre um limite. [...] E o poema se torna claríssimo em sua escureza retinta" 521 . Por sua vez, todavia, a luminosidade superlativa, produzida nesse momento de suprema obscuridade e revelação, ofusca o olhar do eu-lírico - e o do leitor -, por demasiado excessiva. As iluminações, em Paulicéia desvairada, têm a natureza de uma "escuridão dum meio-dia"522, elas ocorrem no apogeu da luz, no instante em que a claridade, em sua intensidade máxima, extingue a visão, equivalendo ao negrume. Assim, a "coroa de luz" do rapsodo modernista é a coroa de luz "da loucura", não a da razão iluminista: a coincidentia oppositorum, que o poeta depara na cidade em plena modernização conservadora, desafia as categorias do entendimento e o regime do conceito ${ }^{523}$.

Para dizer uma formação histórico-social em que o princípio de contradição aparenta não valer - na qual o moderno, ao mesmo tempo em que é o moderno, é também o arcaico e vice-versa -, a linguagem discursiva parecerá insuficiente, e Mário de Andrade assumirá, em Paulicéia desvairada e depois, a música como paradigma de sua poesia: "onde falta a palavra, começa a música", escreveu Jankélévich, considerando que "a música ignora o princípio de contradição". Sendo assim, "a

\footnotetext{
${ }^{520}$ Idem. "Meditação sobre o Tietê", in Lira paulistana, in Poesias completas, op. cit., pp. 386-396.

${ }^{521}$ Idem. "Da obscuridade", in O empalhador de passarinho, op. cit., p. 201.

${ }^{522}$ Idem. "Paisagem no 2", in Paulicéia desvairada, in Poesias completas, op. cit., p. 96.

${ }^{523}$ Idem. "Religião", ibidem, p. 101.
} 
coincidência dos opostos é o regime corrente, embora incompreensível", da arte musical ${ }^{524}$. Nesse ponto, o filósofo francês retoma a concepção romântica, e posteriormente simbolista, de que a música é uma "linguagem acima da linguagem", capaz de exprimir o inexprimível, de representar o irrepresentável - em última instância, de dizer o Absoluto, idéia esta que seria retomada por Adorno ${ }^{525}$. A coincidentia oppositorum, com efeito, é uma das formas clássicas por meio das quais se concebe o Absoluto; a intenção de apreendê-la e representá-la, que se encontra na base de Paulicéia desvairada, possui portanto uma dimensão fáustica, que Pasta Júnior tem demonstrado ser regular na literatura brasileira, na medida em que se trata de demandar o impossível ${ }^{526}$. A representação literária da matéria histórica brasileira tenderá a assumir, na lírica de Mário de Andrade, assim como em Macunaíma, a forma da enunciação do Verbo, da palavra absoluta, ambivalente, em que os opostos coincidem: “A linguagem musical é de um tipo diverso da linguagem significante. Nisso reside seu aspecto religioso. [...] Toda música tem por Idéia a forma do Nome divino. Prece desmitificada [...], a música representa a tentativa humana, ainda que vã, de enunciar o Nome ele-mesmo, ao invés de comunicar significações" 527.

Noutros termos, para representar-se o que não pode, por princípio, ser representado, é preciso que a linguagem seja liberada de sua "função referencial" 528 , ou seja, que sua natureza denotativa seja negada em absoluto, a ponto de a palavra, transgredindo os limites de si mesma, ultrapassar a ordem da representação e tornar-se, como a palavra mítica, a pura presença da coisa mesma que ela anseia dizer ${ }^{529}$. Noutros termos, a distância entre o significante e o significado, distância que confere à linguagem seu caráter de mediação, precisa ser suprimida, de modo que a linguagem

\footnotetext{
524 Jankélévitch, Vladimir. La Musique et l’Ineffable, op. cit., pp. 28, 93-95.

${ }^{525}$ Dahlhaus, Carl. The idea of absolute music, op. cit.

526 Pasta Júnior, José Antonio. “O romance de Rosa - temas do Grande sertão e do Brasil”, in op. cit., p. 69.

${ }^{527}$ Adorno, Theodor W. "Fragment sur les rapports entre musique et langage”, in op. cit., p. 4.

528 Jakobson, Roman. "Linguistique et poétique", in Essais de lingustique générale - 1. Les fondations du langage, Paris: Minuit, 1991, pp. 213-218.

${ }^{529}$ Cassirer, Ernst. Linguagem e mito, São Paulo: Perspectiva, 2003, pp. 74-79.
} 
possa aceder ao estatuto que José Antonio Pasta Júnior definiu como sendo o da mediação que se constitui como imediatidade, um modo paradoxal de aparição da linguagem, vinculado às contradições histórico-sociais brasileiras ${ }^{530}$. Nesse sentido, o lirismo de Paulicéia desvairada se afasta da tendência dominante da poesia moderna ${ }^{531}$.

Entre as artes, a música, justamente, tende a abolir a separação entre a linguagem e o referente, o que levou um filósofo setecentista, atualmente esquecido, a afirmar que "os sons não são a expressão da coisa, eles são a coisa mesma" ${ }^{32}$. A idéia seria desenvolvida por Schopenhauer, para quem a música representa imediatamente a coisa-em-si, a "essência íntima" dos fenômenos, que escapa à apreensão figurativa ou conceitual. De acordo com esse argumento, a música não deixa de ser uma mediação, uma forma de representação, mas é uma "mediação que se apresenta como imediatidade": "Da analogia com as demais artes podemos concluir que também ela, de certa maneira, tem de estar para o mundo como a exposição para o exposto, a cópia para o modelo. [...] Contudo, o ponto de comparação da música com o mundo, a maneira pela qual a primeira está para este como cópia ou repetição, encontra-se profundamente oculto" 533 . Essa colusão, própria da linguagem musical, de mediação e imediatidade decorre, segundo Schopenhauer, do fato de que a música representa algo que, essencialmente, nunca se pode tornar representação, isto é, a "essência do mundo", o universal anterior a toda individuação - em suma, a Vontade ${ }^{534}$. Por isso, "ela é para nós ao mesmo tempo perfeitamente inteligível e completamente inexplicável”, simultânea e superlativamente evidente e obscura ${ }^{535}$.

\footnotetext{
530 O conceito de mediação como imediatidade encontra-se no núcleo do pensamento de Pasta Júnior, e permite a compreensão da coincidência, que o crítico verifica ser recorrente em obras canônicas de nossas letras, de distância e não-distância entre as palavras e as coisas. Pasta Júnior, José Antonio. Pompéia: a metafisica ruinosa d'O Ateneu, op. cit., pp. 170-175. Ver também, do Autor, "O romance de Rosa - temas do Grande sertão e do Brasil”, in op. cit., pp. 61-70.

531 "A distância entre o significado e o significante é um fato constante na poesia moderna". Friedrich, Hugo. Structure de la poésie moderne, op. cit., p. 211.

532 A frase é de Michel-Paul-Guy de Chabanon (1730-1792), violinista, compositor e filósofo da música. Apud Lévi-Strauss, Claude. Regarder écouter lire, Paris: Plon, 1993, p. 96.

533 Schopenhauer, Arthur. Metafisica do Belo, São Paulo: Unesp, 2001, p. 228. Ver também, Idem. O mundo como vontade e representação, Rio de Janeiro: Contraponto, 2001, pp. 269-281.

${ }^{534}$ Schopenhauer, Arthur. Metafisica do Belo, op. cit., p. 229.

${ }^{535}$ Idem. O mundo como vontade e representação, op. cit., p. 278.
} 
Em contexto teórico muito diferente, o pensamento musical de Schopenhauer tem alguma ressonância nas reflexões de Adorno sobre as relações entre a música e a linguagem, reflexões nas quais o autor, para definir a natureza paradoxal da linguagem musical, utiliza, de modo bastante significativo para nós, a imagem da luz que cega, do clarão negro, da visão obscura, que vimos ser recorrente na poesia marioandradina, poesia impregnada de música: “A linguagem significante procura dizer o absoluto de forma mediata, e este absoluto não cessa de lhe escapar, deixando cada intenção particular, dada sua finitude, bem longe atrás si. A música, por sua vez, atinge o absoluto imediatamente, mas ao mesmo tempo ele se lhe torna obscuro, assim como um olho é cegado por uma luz excessiva, e não pode mais ver o que é perfeitamente visível" 536 .

Nos diários de sua famosa viagem à Amazônia, realizada em 1927, Mário de Andrade descreve a experiência de uma luminosidade obcecante como uma autêntica experiência da "vida equatorial", que ele considerava "mais brasileira", por assim dizer, do que a vida no Sul do país. Nesse sentido, ele descreve a experiência de um meio-dia na Ilha de Marajó: “O céu está branco e reflete numa água totalmente branca, um branco feroz, desesperante, luminosíssimo, absurdo, que penetra pelos olhos, pelas narinas, poros, não se resiste, sinto que vou morrer, misericórdia! O melhor é ficar imóvel, nem falar. E a gente vai vivendo de uma outra vida, uma vida metálica, dura, sem entranhas. Não existo. [...] A alma das coisas desapareceu"537. No contexto dos diários marioandradinos, assim como no âmbito mais amplo das reflexões nativistas do escritor, a experiência da luz que cega e "mata" o sujeito tem o significado de uma experiência do Brasil, como tantas outras narradas nas anotações amazônicas.

Conforme o leitor terá percebido, há nessa experiência brasileira uma dimensão sacrificial marcante: envolvido pela luz superlativa, o indivíduo acede a uma "outra vida" por meio da violenta aniquilação de si mesmo. Ao combinar os temas da visão que cega, da perda da alma e do corpo imóvel, a descrição de Mário de Andrade assemelha-

\footnotetext{
536 Adorno, Theodor W. "Fragment sur les rapports entre musique et langage", in Quasi una fantasia, Paris: Gallimard, 1982, p. 6.

${ }^{537}$ Andrade, Mário de. O turista aprendiz, op. cit., p. 162.
} 
se com efeito ao relato de um êxtase místico, semelhança que se revela em um crônica de 1930, quando Mário recorda aquele meio-dia em Marajó: "E aquele meio-dia fulgurante no Arari em Marajó, quando o maior Sol do universo, batendo de chapa no espelho do lago branco: um branco inenarrável, maléfico, num estardalhaço de mil sinos tocando, me envolveu todo como uma presença real de Deus. Tive a impressão de ser engulido, uma coisa ao mesmo tempo sublime e dolorosíssima. O meu espírito desapareceu"538. Ora, o êxtase místico consiste, em última análise, em uma experiência sacrificial sublime, esplêndida: "O corpo, durante o êxtase, parece privado de vida: a respiração torna-se lenta, imperceptível, as extremidades dos membros ficam frias, como se o sangue as tivesse abandonado, e o corpo permanece paralisado na posição em que o êxtase o surpreendeu. [...] A imobilidade é absoluta: o corpo paralisa em uma atitude, em geral a da crucificação, [...] enquanto surge, das profundezas sombrias do inconsciente, [... o eu iluminado" 539 . O êxtase equivale portanto à morte, mas não a uma morte qualquer: ele corresponde, na tradição cristã, em que a experiência extática mais se aproxima de seu próprio conceito, ao traspasse ao mesmo tempo "doloroso e delicioso" do sacrifício - a culminação da imitatio Christi, a repetição do martírio supremo, sob cujo signo, conforme visto, a vida e a obra de Mário de Andrade se organizaram em grande medida.

Note-se, contudo, que no "êxtase" do "turista aprendiz", transcrito acima, ocorre uma inversão do êxtase cristão: neste, o corpo está morto, enquanto a alma, unida à essência divina, vive intensamente; naquele, ao contrário, o espírito se extingue, calcinado, ao passo que a vida se concentra na matéria. Assim, enquanto o êxtase cristão eleva, o êxtase amazônico abate: "Tem monotonias insuportáveis e tem monotonias que a gente não se cansa de gozar. Assim esta do Amazonas. [...] É uma gostosura niilisante. [...] O êxtase vai me abatendo cada vez mais. Me entreguei com uma volúpia que nunca possuí à contemplação dessas coisas, e não tenho por isso o mínimo controle sobre mim mesmo. A inteligência não há meios de reagir nem aquele poucadinho necessário pra

\footnotetext{
${ }^{538}$ Idem. "Cores do Brasil”, in Táxi e crônicas no Diário Nacional, op. cit., p. 219.

${ }^{539}$ Bastide, Roger. Les problèmes de la vie mystique, op. cit., p. 76, 126, 134.
} 
realizar em dados ou em bases de consciência o que os sentidos vão recebendo. Estou ganzlich [completamente] animalizado. [...] Não encontro aquela clarividência discrecionária que pra uso pessoal sempre conservei, mesmo nos momentos de maior prazer. O abatimento intelectual é quase que completo. Vivo de arrastão numa vida de pura sensibilidade" ${ }^{540}$. Assim, se no transporte místico cristão o movimento é de transcendência, na "experiência do Norte" marioandradina, inversamente, ele é de redução à pura imanência, configurando uma espécie de êxtase negativo ${ }^{541}$, por meio do qual o sujeito, ao invés de emancipar-se do mundo material e da finitude, torna-se ainda mais preso a elas, o que configura uma espécie de má-infinidade. Ao contrário de seu próprio modelo - a Paixão de Cristo -, o sacrifício, na vida e na obra de Mário, não liberta.

Essa lógica infernal do martírio marioandradino encontra-se no núcleo de Paulicéia desvairada. "Colloque sentimental", poema que expõe o esforço improfícuo do eu-lírico para despertar, no imigrante aburguesado, um sentimento de piedade social pelos operários da cidade, esforço que assinala os limites ideológicos do próprio livro, abre-se com um verso de evidente conotação sacrificial: "Tenho os pés chagados nos espinhos das calçadas..." ${ }^{542}$. A tarefa, que o eu-lírico assume, de resolver as contradições da cidade - no caso, de favorecer a união entre o rico e o pobre - aparece no poema sob o signo do martírio cristão. Na mesma linha, na dramática "Paisagem no 2", em pleno meio-dia em trevas, meio-dia invernal, o eu-lírico se apresenta como a vítima sacrificial de São Paulo, como a personagem principal de uma espécie de Sagração do Inverno paulistana, cujo rito ele exerce no próprio poema, sem a esperança da renovação da vida, tradicionalmente celebrada nos sacrifícios primaveris, nos quais se inspira, como se sabe, o Sacre de Stravinski, para o qual Nijinski criou uma de suas mais escandalosas coreografias:

\footnotetext{
${ }^{540}$ Carta de Mário de Andrade a Manuel Bandeira, enviada da Amazônia em 1927. In Andrade, Mário de. Correspondência - Mário de Andrade \& Manuel Bandeira, op. cit., p. 346.

${ }^{541}$ Sobre o "êxtase negativo", ver Idem. Ibidem, pp. 108-109, 136.

542 Já em Paulicéia desvairada, portanto, a tentativa de aproximar as classes abastadas dos pobres se realiza na forma do martírio. Andrade, Mário de. "Colloque sentimental", in Paulicéia desvairada, in op. cit., p. 99.
} 
"Escuridão dum meio-dia de invernia...

Marasmos... Estremeções... Brancos...

O céu é toda uma batalha convencional de confetti brancos;

$[\ldots]$

Deus recortou a alma de Paulicéia

num cor de cinza sem odor...

Oh! para além vivem as primaveras eternas!...

$[\ldots]$

São Paulo é um palco de bailados russos.

Sarabandam a tísica, a ambição, as invejas, os crimes

e também as apoteoses da ilusão...

Mas o Nijinsky sou eu!

E vem a Morte, minha Karsavina!

Quá, quá, quá! Vamos dançar o fox-trot da desesperança." 543

Colocando-se no centro da vertigem paulistana, o eu-lírico chama sobre si mesmo, contrai em seu próprio corpo os antagonismos da cidade e os deixa atuar dramaticamente. Desse modo, assume a posição trágica da vítima sacrificial: "sobre a vítima expiatória são rejeitadas todas as contradições da sociedade”, escreveu Girard ${ }^{544}$. A vítima encarna as antíteses sociais, nela convergem os opostos irredutíveis que dilaceram a comunidade. A dualidade, aspecto marcante dos principais heróis de nossas letras ${ }^{545}$, é portanto uma característica essencial da vítima expiatória: “a vítima

\footnotetext{
${ }^{543}$ Idem. "Paisagem no 2", ibidem, p. 97. Sobre o significado histórico-social do sacrifício na Sagração da Primavera, de Stravinski, ver Adorno, Theodor W. Philosophie de la nouvelle musique, op. cit., pp. 157-171.

${ }^{544}$ Girard, René. A violência e o sagrado, op. cit., p. 345.

545 Candido, Antonio. "O homem dos avessos", in Tese e antitese, São Paulo: T. A. Queiroz, 2002, pp. 121-139; "Dialética da malandragem", in $O$ discurso e a cidade, op. cit., pp. 17-46; "De cortiço a cortiço", ibidem, pp. 105-129; "Estrutura literária e função histórica", in Literatura e sociedade, op. cit., pp. 169-192. Schwarz, Roberto. Um mestre na periferia do capitalismo, São Paulo: Editora 34/Duas Cidades, 2000. Pasta Júnior, José Antonio. "O romance de Rosa - temas do Grande sertão e do Brasil", in op. cit., pp. 61-70. Idem. "Tristes estrelas da Ursa - Macunaíma", in op. cit., pp. 27-32. Idem. « Changement et idée fixe (L'autre dans le roman brésilien) », in op. cit.
} 
representa tanto a morte como a vida, a doença como a saúde, o pecado como o mérito, a falsidade como a verdade" 546 . No instante do sacrifício, paroxismo de toda vida religiosa, os opostos concentrados no corpo e na alma da vítima coincidem, identificamse e passam um no outro, em uma brevíssima e aterrorizante união de contrários, que se encontra inclusive no tom de deboche de humor negro da gargalhada do último verso do poema acima. Quando o carrasco golpeia o "bode expiatório”, o sagrado é o profano e o profano, o sagrado; a morte é a vida e a vida, a morte; o veneno é o remédio e o remédio, o veneno; o crime é a reparação e a reparação, o crime. Logo em seguida à imolação, é verdade, o rito tratará de recompor essas distinções, marcará as diferenças entre os deuses e os homens, entre o bem e o mal, entre o "mesmo" e o "outro", garantindo dessa forma a sobrevivência da sociedade e da cultura. No instante sacrificial, entretanto, tem vigência uma espécie de suprema coincidentia oppositorum, pois que nele as contradições superlativas, as polarizações diametrais, as oposições absolutas, aquelas que estruturam a natureza e a civilização, são canceladas, ao mesmo tempo em que se apresentam em seu momento de acirramento máximo.

À vista disso, considerando-se que o anseio maior do eu-lírico de Paulicéia consiste não apenas em representar os paradoxos, antíteses, ambigüidades, hibridismos, reversibilidades etc. característicos da São Paulo dos frementes anos 1920, mas em última instância em dizer a coincidência dos contrários que o sujeito depara, a todo momento, na cidade violentamente marcada pela modernização conservadora, não surpreende o fato de que o livro se encerre, no oratório "As enfibraturas do Ipiranga", com as palavras expirantes de vítimas sacrificiais - os modernistas - que, após declararem, exasperados, os princípios da poética renovadora, chamam para si o martírio crístico:

\footnotetext{
“A passiflora! o espanto!... a loucura! o desejo!...

Cravos!... Mais cravos... para... a nossa..."
}

\footnotetext{
546 Hubert, Henri; Mauss, Marcel. "Ensaio sobre a natureza e a função do sacrifício", in Mauss, Marcel. Ensaios de sociologia, op. cit., p. 196.
} 
A palavra faltante, os modernistas tombam no solo antes de pronunciá-la, é a palavra "cruz", conforme aparições anteriores do mesmo verso, nas quais este ainda é declamado com energia: “Cravos! mais cravos para a nossa cruz!”. Além disso, como o leitor terá notado, Mário menciona a passiflora, que corresponde ao maracujá e a sua flor, a flor-da-Paixão, a qual, segundo as interpretações tradicionais, carrega os signos da crucificação de Cristo: a coroa de espinhos, as chagas, os cravos etc.

Proferida em conjunto com a pregação dos novos valores artísticos, a invocação do martírio revela a natureza apostólica e sacrificial que a missão de modernizar e nacionalizar a literatura brasileira possui em Paulicéia desvairada547. No "oratório profano" que fecha o livro, apostolado e sacrifício são dramatizados, consumando-se desse modo uma tendência presente em Paulicéia tanto no "Prefácio Interessantíssimo", onde se estabelece um colóquio explícito com o leitor ${ }^{548}$, como em quase todos os poemas que compõem o livro, repletos de diálogos, interpelações, ordens, invocações, súplicas, convocações, insultos etc ${ }^{549}$. Nas "Enfibraturas do Ipiranga", a poesia se converte afinal em drama, e tende ao rito: o oratório, gênero dramático, tem como um de seus temas mais fortes a representação da Paixão de Cristo ${ }^{550}$.

A classificação do oratório como "profano", que Mário de Andrade confere às "Enfibraturas", indicando que o texto não tem origem bíblica e que o assunto da peça não é religioso, não diminui o caráter ritual da obra, considerando-se que este depende, sobretudo, do modo como os temas se precipitam em forma literária, sejam eles "sagrados" ou não. Ademais, no pensamento e nas obras de Mário de Andrade, o

\footnotetext{
547 Vale lembrar que a motivação imediata da composição de Paulicéia, segundo os relatos do próprio Mário de Andrade, foi uma discussão acalorada que o escritor teve com a família sobre a Cabeça de Cristo, de Brecheret. Os parentes de Mário não aceitavam a representação modernista de Jesus.

548 "Desculpe-me por estar tão atrasado dos movimentos artísticos atuais. [...] Você já leu São João Evangelista? Walt Whitman? Mallarmé? Verhaeren? [...] Sei construir teorias engenhosas. Quer ver? [...] Você está vendo como costumo andar sozinho... [...] Há no meu livro, e não me desagrada, tendência pronunciadamente intelectualista. Que quer você? [...] Pronomes? Escrevo brasileiro. [...]”. Andrade, Mário de. "Prefácio Interessantíssimo", in op. cit., pp. 58-77.

549 Valem-se de recursos dramáticos os poemas "Inspiração", "A escalada", "Rua de São Bento", "Tietê", "Paisagem no 1", "Ode ao burguês", "Domingo", "O domador", "Anhangabaú", "Noturno", "Paisagem no 2", “Tu”, "Paisagem no 3", "Colloque sentimental", "Religião" e "Paisagem no 4".

550 Sob outro ângulo, o teor sacrificial de "As enfribaturas do Ipiranga" é comentado por José Miguel Wisnik em Dança dramática (poesia/ música brasileira), Tese de Doutoramento em Teoria Literária e Literatura Comparada apresentada à Faculdade de Filosofia, Letras e Ciências Humanas da USP, São Paulo, 1979, pp. 119-124.
} 
sagrado e o profano, categorias absolutamente heterogêneas por princípio ${ }^{551}$, funcionam justamente segundo um regime em que se convertem um no outro, de modo que sua significação somente será compreendida nesse contexto de conversão recíproca. Em resumo, os aspectos míticos e rituais da literatura marioandradina prendem-se aos problemas históricos que ela procura especificar e equacionar; seu sentido - e seu interesse - reside nesse vínculo essencial com a matéria social, de cujas contradições eles surgem como soluções extremas.

Pense-se, por exemplo, na natureza mágico-religiosa que a crise da economia cafeeira e a decorrente revolução comunista possuem no Café, ópera que Mário define como uma "tragédia secular", assim como classifica "As enfibraturas do Ipiranga" como "oratório profano". Sem exagero, pode-se mesmo dizer que Café é a obra mais "histórica" de Mário de Andrade, aquela em que é mais marcante a "intenção intelectual e estética" de "celebrar o panorama dramático da história", de acordo com as palavras do escritor acerca de Bóris Godunov, a ópera de Mussórgski que o inspirou na composição de sua própria ópera ${ }^{552}$. Nesse sentido, como notou Jorge Coli, Café vincula-se à tradição do Grand Opéra, em que a História. Ora, no Café, embora a história esteja em toda parte, é o “princípio místico de ‘morte e ressurreição' do deus da natureza", na expressão do próprio Mário, que explica a instabilidade econômica brasileira e propicia a conflagração de um movimento revolucionário em São Paulo: "A oscilação da economia paulista determina-se pela morte e ressurreição ânua do café [...]. Desde que depereceu o produto que faz a riqueza normal duma terra, vem a insatisfação pública que acaba se revoltando e mudando o regime"553. Desse modo, o caráter precário da economia da República Velha, resultante da radicalização da "vocação agrícola" do país nos três primeiros decênios do século XX, prende-se na ópera de Mário de Andrade a uma lei mítica que tem por base uma lei natural, portanto a um "mito da natureza", no qual o café, o "grão pequenino", figura como deus, sendo invocado ao longo de todo o texto, inclusive durante revolução, por meio da qual o povo pretende

\footnotetext{
${ }^{551}$ Durkheim, Émile. As formas elementares da vida religiosa, op. cit., pp. 19-24.

${ }^{552}$ Andrade, Mário de. “Boris Godunov", [1943], in Coli, Jorge. Música final, op. cit., p. 94.

${ }^{553}$ Idem. "Psicologia da criação" [1943], ibidem, p. 105.
} 
ressuscitá-lo: "Logo eu te acordarei da paz falsa da morte/ E tu reviverás, razão da minha vida,/ Grão pequenino do café!"’. O processo histórico é movido, portanto, por um princípio que não apenas o transcende como o contraria, pois que determina um regime de tempo cíclico, marcado pelo eterno retorno do mesmo, e estabelece uma trágica dinâmica fatalista da história.

Não obstante, o salto mítico que ocorre no Café decorre de contradições históricas profundas, que ainda hoje roubam o fôlego dos especialistas que as procuram compreender e especificar, e que Mário de Andrade, apesar de um esforço extremo em contrário, não conseguiu resolver. São elas, em síntese, o intrincado conjunto de contradições em que se baseava a economia cafeeira e o paradoxo de que, ao final da República Velha, "tudo exigia uma revolução, mas nada permitia a sua efetiva realização" "554. Embora oculte as verdadeiras causas econômicas da débâcle do café em São Paulo, ou seja, os processos humanos, internacionais inclusive, que estavam na origem da "catástrofe", a feição mágico-religiosa que a crise e a revolução assumem na ópera de Mário aponta para tensões sociais específicas do Brasil da época. A economia submetida a leis naturais ou míticas, exteriores e superiores a ela, constitui uma imagem eloqüente, ainda que enganosa, pois que não-distanciada, de um sistema econômico totalmente dependente das oscilações do mercado externo. $\mathrm{Na}$ mesma linha, a irracionalidade de um sistema econômico que se auto-consumia, que se condenava à medida que se expandia, no qual produção e destruição condicionavam-se reciprocamente, "resolve-se" na irracionalidade do mito, segundo a qual "tudo o que acontece deve expiar uma pena pelo fato de ter acontecido" 555 .

Como é sabido, a economia cafeeira exigirá, no paroxismo de suas contradições, a queima, a destruição, o sacrifício, em suma, do próprio café produzido, sobre o que escreveu Mário de Andrade, em artigo de 1932: “Agora estão queimando café aqui mesmo, nas barbas da cidade. Da minha casa se enxerga. [...] É o trabalho paulista queimando. [...] O que acaba com a gente é isso: presenciar noite e dia toda essa

\footnotetext{
554 José Antonio Pasta Júnior, “Tristes estrelas da Ursa - Macunaíma”, in op. cit., p. 31.

${ }^{555}$ Adorno, Theodor W.; Horkheimer, Max. Dialética do Esclarecimento, op. cit., p. 26.
} 
prodigiosa massa de trabalho humano, de esperança de salvação, de ambições, de fadiga, engenho, atividade, tudo sacrificado pela estupidez... humana"556. A queima do café impregna a atmosfera da ópera de Mário. Os colonos abandonam os campos sob o seu signo: "Como o fumo ácido afugenta os insetos de beira-rio, eles também partiam de seus chãos, afugentados pela fumaça torva do café queimado" ${ }^{\text {557 }}$. O êxodo se dá sobre o "fundo vermelho da tarde" e, mesmo quando escurece, persiste no horizonte "uma faixa encarnada violenta", um "listrão encarnado do último sol", que lembra o de um grande incêndio distante. Café, vale lembrar, encerra-se com a vitória da revolução em meio a um incêndio prodigioso, anunciado já na primeira cena, no porto parado, e que configura uma paradoxal imagem apocalíptica de um Dia Novo, quando a revolta se desata "com seu rancho de peste e de morte/ Varrendo tudo na batucada infernal". "Os incêndios tomaram tanto a cidade que tudo está claro agora, violentamente clareado numa luz vermelha", explica Mário, descrevendo a última cena da ópera, em que os revolucionários bradam: “- Fogo e mais fogo! Fogo até morrer! [...] É de parte a parte/ Fogo na nação!" 558 .

Mais precisamente, de acordo com as indicações do escritor o pano deve cair no instante em que o incêndio atinge seu grau máximo, ou seja, quando o clarão, de tão intenso, tudo ofusca: "Os holofotes estraçalham as últimas escurezas esparsas no ar", indica o autor ${ }^{559}$. A visão da sociedade liberada culmina portanto na visão, já familiar para nós, que cega por excesso de luz, paroxismo de vida que é morte absoluta, vida e morte no fogo. Com efeito, nos termos de Bachelard, o fogo é "ultra-vivente" e provoca "a morte total, sem traços"; ou seja, ele é duplo ao extremo: "entre todos os fenômenos, o fogo é verdadeiramente o único que pode receber nitidamente os dois valores: o bem e

\footnotetext{
${ }^{556}$ Andrade, Mário de. “Café queimado”, in Táxi e crônicas do Diário Nacional, op. cit., p. 419.

${ }^{557}$ Idem. Café, in Poesias completas, op. cit., p. 413.

558 Idem. Ibidem, pp. 421, 446-447. A ópera tem afinidades eletivas com o fogo. Não são poucas as obras do gênero que terminam com incêndios colossais, como o Crepúsculo dos deuses, de Wagner, ou mesmo as que se encerram com sacrifícios no fogo, como A Valquíria, do mesmo autor, e a Norma, de Bellini. Vale lembrar, ainda, que são raras as casas de ópera que não se incendiaram elas mesmas pelo menos uma vez na história, e que uma das mais célebres, a ópera de Veneza, se chama Fênix... Borel, Vincent. Un curieux à l'opéra, Arles: Actes Sud, 2006, pp. 49-55.
}

${ }^{559}$ Andrade, Mário de. Café, in op. cit., p. 421. 
o mal. Ele brilha no Paraíso. Ele queima no Inferno"560. Devido a sua dualidade essencial, como elemento que dá a vida e a morte, o fogo é o fenômeno privilegiado em que se manifesta o sagrado, sendo também, portanto, o elemento sacrificial por excelência, tendo em vista que o sacrifício consiste sobretudo na consagração de uma vítima $^{561}$. Ao ser consumida pelo fogo, a vítima é consumida pelo próprio sagrado, de modo que a imolação no fogo configura a imagem mesma da consagração: “O sagrado é o incêndio ilimitado, ele se propaga, ele irradia calor e luz, ele incendeia e cega" ${ }^{" 562}$. No limite, toda consagração é em alguma medida um sacrifício, pois supõe que o objeto deve morrer como profano para que possa nascer como sagrado ${ }^{563}$. Sendo assim, o sacrifício, por sua vez, é a forma suprema da consagração e o fogo, o meio em que esta se realiza em seu mais alto grau: se, no sacrifício, a vítima passa ao domínio do sagrado à medida que é destruída, nada melhor para consagrá-la ao máximo do que o fogo, que destrói por completo as coisas. Aniquilada no mundo profano, a vítima renasce por inteiro no além. No grande incêndio final de Café, quando São Paulo inteira queima em sacrifício coletivo, projeta-se a utopia.

$\mathrm{Na}$ ópera de Mário, a revolução tem, de fato, uma natureza sacrificial: a revolta popular insere-se, conforme dito, no interior da lógica mais ampla do princípio de morte e ressurreição próprio dos cultos de vegetação, princípio que tem em seu núcleo o sacrifício, de acordo com o estudo clássico de Frazer, que Mário de Andrade conhecia bem $^{564}$. Nesse contexto, uma série de imagens e de referências sacrificiais atravessa os quadros que compõem Café. Na cena "Câmara Ballet", por exemplo, a dolorosa e delirante endeixa em que a Mãe profetiza a revolução incorpora o Canto da Verônica, que constitui, no Brasil, um momento dramático da Procissão dos Passos da Paixão, quando a Verônica lutuosa desenrola lentamente o "vero ícone", o pano com a marca em

\footnotetext{
${ }^{560}$ Bachelard, Gaston. La psychanalyse du feu, Paris: Gallimard, 2006, p. 23.

561 Hubert, Henri; Mauss, Marcel. "Ensaio sobre a natureza e a função do sacrifício”, in Mauss, Marcel. Ensaios de sociologia, op. cit., p. 147.

562 Bataille, Georges. Théorie de la religion, Paris: Gallimard, 1973.

${ }^{563}$ Durkheim, Émile. As formas elementares da vida religiosa, op. cit., pp. 22-23.

${ }^{564}$ Frazer, James George. Le Rameau d'Or, op.cit..
} 
sangue do rosto de Cristo, enquanto entoa, em agudos pungentes, o verso tristíssimo: “Falai si há dor que se compare à minha!"(Si est dolor sicut dolor meo $)^{565}$. Como se sabe, Verônica, segundo a tradição cristã, é a mulher que enxugou a face ensangüentada de Jesus na sexta estação da Via-Crúcis, daí seu canto fazer parte dos ritos Semana Santa. Na ópera de Mário, a endeixa da Mãe descreve justamente a imagem de um cortejo, o êxodo dos colonos, que abandonam as fazendas de café rumo a São Paulo. Assim como Verônica expõe a imagem do Cristo supliciado a caminho do Calvário, a Mãe de Café apresenta ao público o quadro dos colonos percorrendo uma espécie de Via Dolorosa:

"Falai si há dor que se compare à minha!..

Nos caminhos da noite pressaga

Os infelizes vêm chegando, vêm chegando

Conduzidos pela estrela da cidade.

$[\ldots]$

São os famintos, são os rotos, são os escravos,

São os mil e um cativos da vida em procissão.

Falai!...

Falai si há dor que se compare à minha!..." 566

Nos termos do próprio Mário de Andrade, o êxodo dos colonos configura-se como uma "marcha de supliciados" em direção à cidade: "Naquele estrondar de uivos, de lamentos lancinantes, os grupos vão atravessando a cena toda e desaparecem. Ritmo cadenciado, lento, aos empuxões pesados. Ritmo de coisa que marcha por desgraça,

\footnotetext{
565 A endeixa, ou endecha, é um "canto triste, fúnebre". Andrade, Mário de. Dicionário musical brasileiro (coordenação de Oneyda Alvarenga e Flávia Camargo Toni), Belo Horizonte: Itatiaia, 1999, p. 201.

566 Andrade, Mário de. Café, in op. cit., p. 437.
} 
ritmo de supliciados"567. Enquanto a crucifixão é o ponto de chegada da Via-Crúcis, a revolução é termo da "Paixão" dos colonos de Café. Não por acaso, a cena da luta tem em seu centro a imagem de uma Pietà, um chefe revolucionário morto nos braços de uma mulher que chora sobre seu corpo. É com o chefe sacrificado a seus pés que a Mãe se imobiliza, como se se tornasse uma estátua, e canta o "hino da vitória da vida", no último quadro da ópera. A idéia mística da ressurreição, a que a revolução social aqui se vincula, tem no Café a marca decisiva do sacrifício.

Antes, porém, da apoteose final, a morte do chefe leva as mulheres, que aguardavam notícias e cuidavam dos feridos, a "entranharem-se na sanha da luta", o que logo produz outra cena sacrificial, cujo modelo, desta vez, não é o martírio de Cristo, mas o sacrifício ligado ao culto de Dioniso. Conforme a luta se intensifica, um soldado governista pula no pátio do cortiço, onde as mulheres se encontram, e ajoelha-se a seus pés, pedindo-lhes que lhe poupem a vida, mas "elas caem sobre ele e o estraçalham sem piedade, sanhudas" ${ }^{568}$. Noutros termos, as pietás convertem-se em mênades e, em transe, "sanhudas", despedaçam o soldado governista, imagem que remete de modo inequívoco à realização do sparagmós, o sacrifício por despedaçamento coletivo da vítima, culminação tradicional do transe dionisíaco das bacantes ${ }^{569}$. A revolução aparece, então, como sacrifício do inimigo. Concluída a "matança" (a expressão é dos próprios revolucionários), as mulheres se reúnem no palco, compondo um quadro verdadeiramente bacântico, como tivessem acabado de devorar Penteu: "No delírio da vitória, vem a Mãe, [...] vem completamente louca, delirando. [...] Avança, corre, seguida de muitas mulheres tão selvagens como ela, tão assanhadas, tão doidas, manchadas de sangue, rasgadas, muitos revoltosos as seguem cercando o grupo feroz.

567 Idem. Ibidem, p. 414. Salvo engano, este cortejo de Café tem pelo menos dois predecessores na tradição operística. São eles a procissão dos penitentes de Tanhäuser e a passagem dos peregrinos em lamentação na abertura de Bóris Godunov, provavelmente o modelo mais imediato da cena composta por Mário de Andrade. Sob esse ângulo, pode-se dizer que o êxodo de Café reúne o caráter sacrificial da procissão wagneriana e a destinação política do préstito de Mussórgski, pois que a marcha dos colonos se converterá na revolução.

568 Idem. Ibidem, p. 419.

569 Jeanmaire, Henri. Dionysos: histoire du culte de Bacchus, Paris: Payot, 1991, pp. 157-219. A conversão de pietás em mênades na cena final do Café foi identificada por Sérgio Ricardo de Carvalho em $O$ drama impossível: teatro modernista de António de Alcântara Machado, Oswald de Andrade e Mário de Andrade. Tese de Doutoramento em Literatura Brasileira apresentada à Faculdade de Filosofia, Letras e Ciências Humanas da USP, São Paulo, 2003, pp. 175-200. 
Ferozes, ferozes, todos rindo em esgares horríveis, caras numa exaltação primária, são monstros admiráveis irracionais, faz medo olhar" ${ }^{570}$.

Não obstante, o transe dionisíaco das mulheres, que contagia afinal todos os revolucionários, constitui uma experiência sacrificial em si mesma. Conforme se verá ao longo deste trabalho, o lado católico e o lado dionisíaco de Mário de Andrade, o aspecto sacrificial e o aspecto coreográfico de sua literatura, a disposição para o sofrimento e a disposição para o gozo da vida, por fim, encontram-se intimamente relacionados na vida e na obra do escritor. Eles são, com efeito, formas específicas de uma mesma experiência fundamental: a passagem do ser ao não-ser, como solução paroxística e paradoxal de contradições histórico-sociais duríssimas, que Mário de Andrade, como nenhum outro intelectual brasileiro, até onde sei, "chamava sobre si mesmo, assumia em seu próprio corpo e deixava atuar", sem recuar diante do dilaceramento que a exasperação desses conflitos implicava ${ }^{571}$. No Café, cristianismo e dionisismo, sacrifício e transe convergem na imagem do vinho, evocado no "Hino da Fonte da Vida", o canto final da ópera, em que há uma reminiscência da "Ode ao burguês":

\author{
"Eu odeio os que amontoam (reservam) \\ Eu odeio os esquecidos \\ Que não provam deste vinho \\ Sangüíneo das multidões."
}

O vinho é o sangue de Cristo e a embriaguez de Dioniso ao mesmo tempo. Seu vínculo simbólico com o sacrifício e sua virtude inebriante estão intimamente relacionados: o vinho provoca o enthousiasmós justamente porque é o sangue divino, o sangue da vítima sacrificial, consagrada. Beber o vinho significa ingerir o próprio sagrado, assumir o sagrado no interior do próprio corpo, tornar-se também, portanto,

\footnotetext{
570 Andrade, Mário de. Café, in op. cit., p. 420.

${ }^{571}$ Pasta Júnior, José Antonio. “Tristes estrelas da Ursa - Macunaíma”, in op. cit., p. 31.
} 
vítima sacrificial ${ }^{572}$. O sujeito que dele se embriaga arde em transe, seu sangue ferve, pois o vinho é de "natureza ígnea", e sua ação provoca, assim como o fogo mítico, a vida por meio da morte, a morte por meio da vida ${ }^{573}$. No fundo, pois, o transe dionisíaco constitui uma experiência sacrificial: "entre as convulsões da vítima sacrificial nos transes de sua agonia e a agitação convulsiva do possuído, interpretadas como manifestações de uma presença e de uma possessão divinas, uma expressa analogia pode ser percebida" 574 .

Com efeito, o transe de possessão, como o sacrifício, é uma forma de sacralização do indivíduo por meio de seu próprio aniquilamento, com a diferença de que, na possessão, a morte é temporária. De todo modo, ser possuído significa morrer como pessoa e tornar-se o próprio deus ${ }^{575}$. Em transe, o sujeito passa de forma violenta para o que lhe é absolutamente outro, ou seja, para o sagrado e para a morte ${ }^{76}$. No êxtase dionisíaco, essa passagem se radicaliza. Dioniso, o Estrangeiro, encarna a figura do Outro ${ }^{577}$, e embora seja o deus da renovação da vegetação - ou, por isso mesmo -, Dioniso é a própria morte: “O profundo Heráclito de Éfeso sabia e dizia que Dioniso e Hades são o mesmo" 578 . O transe, em suma, é um traspasse, de forma que o possuído está presente e ausente ao mesmo tempo - corpo presente, espírito ausente. Ora, como terá inferido o leitor, o objeto por excelência em que se expressa essa presença-ausência a que nos referimos é o cadáver e, no caso específico do transe de possessão, o cadáver da vítima sacrificial, ou seja, o corpo sacralizado. Dioniso conduz seus seguidores às beatitudes de uma vida além-túmulo579: "para os fiéis, em comunhão feliz com o deus,

\footnotetext{
572 A associação entre o sangue da vítima expiatória e a bebida que embriaga e leva ao transe é notada pelo próprio Mário de Andrade em uma crônica de 1944. Andrade, Mário de. "Cantador cachaceiro - I", in Vida do cantador (ed. de Raimunda de Brito Batista), Belo Horizonte: Villa Rica, 1993, pp. 91-96.

573 Detienne, Marcel. Dionysos à ciel ouvert, Paris: Hachette, 1998, pp. 56-57.

574 Jeanmaire, Henri. Dionysos: histoire du culte de Bacchus, op. cit., p. 158.

575 Rouget, Gilbert. La musique et la transe, op. cit., pp. 39-85.

576 Sobre o sagrado como ganz andere, como "absolutamente outro", ver Otto, Rudolf, Le sacré, op. cit. Sobre a morte como "outro absoluto", ver Jankélévitch, Vladimir. La mort, Paris: Flammarion, 1999.

577 Vernant, Jean-Pierre. Mythe et religion en Grèce ancienne, Paris: Seuil, 1990, p. 99.

578 Jeanmaire, Henri. Dionysos: histoire du culte de Bacchus, op. cit., p. 56.

${ }^{579}$ Idem. Ibidem, p. 430.
} 
ele traz a alegria sobrenatural de uma evasão momentânea para um mundo de idade de ouro, onde todas as criaturas se reencontram fraternalmente misturadas" ${ }^{\circ 80}$. De modo análogo, em Café, no apogeu do transe dionisíaco projeta-se a utopia.

Mas assim como a feição mítica da crise, também a marca utópica da revolução procede da história na ópera de Mário, pois se origina do fato de que as condições histórico-sociais, no Brasil dos anos 1920-30, pediam com urgência uma revolução, ao mesmo tempo em que nada, nelas, permitia a efetiva realização de um movimento revolucionário. O princípio de morte e ressurreição do espírito da vegetação, que move a revolta contra o estado de coisas - "A lei maior te fataliza o braço", diz um dos coros ao povo - substitui, na economia interna da obra, a ausência de reais condições revolucionárias no Brasil da época ${ }^{581}$. Em Café, o povo não quer realizar a revolução, mas a crise leva a miséria a um estágio que não se pode mais suportar: "Tem momentos nesta vida dura em que a gente se revolta, não é porque queira decididamente se revoltar, mas porque uma força maior move a gente e se fica sem capacidade mais pra não se revoltar", escreve Mário na "Concepção Melodramática"582. A revolução “estoura”, em boa medida, contra a vontade do povo, motivada por uma pressão social intolerável: "[A revolução] acabou estourando mesmo. Chegara enfim o tempo em que o povo não tivera capacidade mais pra não se revoltar, se revoltara”. A fome é a causa social da revolta, mas ela somente se converte em luta social por causa do influxo do espírito vegetal: "De cada planta o cafezal distila o veneno do ódio". É o grão pequenino e sagrado do café que revela aos trabalhadores o sentido revolucionário da fome eles estão passando: "Aquela fome que eles sentiam não era apenas uma fome de alimento, mas outra maior, a fome milenar dos subjugados, fome de outra justiça na terra, de outra igualdade de direitos para lutar e vencer”. A revolução, no Café, é presidida por uma espécie de fatalismo grandioso - o que a ela confere um pathos trágico, de acordo com as concepções de Mário: nas palavras do escritor, o elemento

\footnotetext{
${ }^{580}$ Vernant, Jean-Pierre. Mythe et religion en Grèce ancienne, op. cit., p. 101.

581 Fausto, Boris. "Estado, classe trabalhadora e burguesia industrial (1920-1945): uma revisão", in op. cit., pp. 6-21.

582 Andrade, Mário de. Café, in op. cit., p. 406.
} 
essencial do trágico, é “a grandiosidade do Fatum”, ou seja, do destino; trágico, para Mário de Andrade, é o grande acontecimento provocado por leis superiores aos homens ${ }^{583}$.

A falta de condições prévias para a realização de uma revolução no país, que passou a interessar Mário de Andrade a partir do movimento de 1930, parece ter recebido do escritor uma atenção especial em 1942, quando foi escrita a a última versão de Café. Nesse ano, Mário concluiu o conto "Primeiro de Maio", em que ele estuda, como vimos anteriormente, o êxito dos mecanismos de desmobilização do proletariado utilizados no decênio de 1930 pelo Estado getulista e pelas elites pauslitanas, e a conseqüente desorganização política em que se encontravam os trabalhadores de São Paulo na época. Também em 1942, em carta a Paulo Duarte, Mário comenta o absenteísmo medíocre e covarde da "classe média" brasileira, a qual, segundo ele, embore tenha o desejo de derrubar Getúlio, não se dispõe a trocar a cômoda rotina da vida privada pela ação política: "Coisas incríveis, coisas impossíveis, em que só transparecem os desejos, as aspirações, homem, creio que de uma imensa maioria. Mas essa maioria, nem pensa em fazer nada. Vai pra casa, vai pro servicinho, se irrita com o racionamento de gasolina" 584 .

Mário de Andrade pretendia representar o baixo grau de politização da população brasileira no romance Café, que ele começou a escrever antes de optar pela forma da ópera. Em carta a Moacir Werneck de Castro, resumindo o enredo que tinha em mente, conta Mário que a personagem principal do romance, Chico Antônio, cantador nordestino imigrado para São Paulo, se alistaria "por medo", "em sua gratuidade de quase-escravo", nas hostes de Júlio Prestes, e se encontraria, no final do romance, “completamente safadizado, embarcando na multidão e dando vivas a Getúlio Vargas..." ${ }^{985}$. Nem a adesão do cantador à marcha de 1927 nem o seu entusiasmo com o golpe de Vargas seriam representadas como opções políticas, ao contrário: nos dois casos, Chico Antônio não saberia o que o motivava. Desse modo, Mário tinha a intenção

\footnotetext{
583 Idem. "Do Trágico" [1939], in O empalhador de passarinho, op. cit., p. 114.

${ }^{584}$ Duarte, Paulo. Mário de Andrade por ele mesmo, op. cit., p. 234.

585 Andrade, Mário de. 71 cartas de Mário de Andrade, op. cit., p. 139.
} 
de concluir seu romance histórico com a vitória da Revolução de 1930, mas apresentando-a como uma falsa revolução. Na ópera, diferentemente, onde o propósito de coletivizar o povo suplanta o desígnio, que norteava a composição do romance, de representar de maneira distanciada o processo histórico, ele optou por encenar uma verdadeira revolução popular no palco - a revolução que 1930 ficara devendo. Revolução imaginária, tão urgente quanto improvável, a que somente um princípio mágico-religioso poderia, em última instância, dar sustentação. Como se sabe, o mito consiste, entre outras coisas, em uma "solução imaginária para tensões, conflitos e contradições que não encontram caminhos para serem resolvidos no nível da realidade"586. Do acirramento da contradição entre a necessidade premente de uma revolução e a ausência de situação revolucionária deriva o salto metafísico por meio do qual se realiza a revolta social em Café.

O impulso da obra para a esfera mágico-religiosa assinala também as dificuldades específicas de realização de uma literatura engajada em uma sociedade marcada pela extrema rarefação da luta de classes. O longo período que separa a concepção e a composição da obra sugere, por si mesmo, a existência e a importância desses impasses: idealizada no início dos anos 1930, a "tragédia secular" de Mário de Andrade somente seria redigida nos últimos meses de 1942. Segundo o escritor, assim como a revolução constitui-se no Café como fatalidade, ou seja, participa da ordem mítica - do destino, também a composição da ópera coletivista somente pôde realizar-se quando movida por um princípio exterior, "superior" ao mundo dos homens: em carta de 1944 a Drummond, escreve Mário que Café, “ideado por 1933”, "só chegou em outubro de 42", pois para escrevê-lo, diz, foi preciso "estar fatalizado, ser mandado por qualquer coisa que eu não sei bem o que é, que independe de mim, que é superior a mim, e me manda, e sou obrigado a obedecer"587.

\footnotetext{
${ }^{586}$ Chauí, Marilena. Brasil, mito fundador e sociedade autoritária, São Paulo: Perseu Abramo, 2001, p. 8.

${ }^{587}$ Idem. A lição do amigo, op. cit., p. 233, grifo meu. Mário dedicou uma atenção especial ao processo de criação de Café, analisando-o em cartas e até mesmo em um artigo sobre a gênese da obra. Ver, do autor, "Psicologia da criação", in Coli, Jorge. Op. cit., pp. 104-107.
} 
Na literatura marioandradina, portanto, a representação da história tende a produzir configurações míticas ${ }^{588}$, ao passo que o mito se prende à "precariedade" das contingências históricas, perdendo seu "valor intrínseco" de "estrutura permanente”, nos termos de Lévi-Strauss ${ }^{589}$. Sendo assim, pode-se dizer, com José Antonio Pasta Júnior, que a obra de Mário "não acede a uma transcendência autêntica - ou a uma metafísica propriamente dita - assim como tampouco se instala num aquém isento de dimensão transcendental”590. A presença infalível dessa lógica paradoxal nas obras centrais de Mário de Andrade, ou seja, naquelas que procuram dar forma à matéria brasileira, assinala que as passagens do sagrado no profano e do profano no sagrado a que nos referimos não são fortuitas, mas resultam do embate do escritor com a especificidades da formação histórica que ele buscava apreender.

Nada mais distante do resultado dessa combinação de história e religião na produção artística de Mário de Andrade, todavia, do que a configuração de uma plenitude em que a existência humana e as esferas metafísicas, unidas em harmonia, iluminam-se reciprocamente e produzem, por meio dessa correspondência, uma síntese superior, restaurando formas de representação de "culturas fechadas", anteriores à experiência da vida contingente, ou seja, às divisões, próprias da modernidade, que tornam alheios entre si os homens e os deuses, a existência e o destino ${ }^{591}$. Caso afirmasse essa síntese estável, a literatura marioandradina se constituiria em ideologia, por apresentar como totalidade integrada uma sociedade fraturada ${ }^{592}$. Ao invés disso, porém, nas obras de Mário o processo de conversão recíproca entre o profano e o sagrado, entre a história e o mito, é propriamente ruinoso, e seus resultados costumam

\footnotetext{
${ }^{588}$ É também o caso de Macunaíma, a principal obra Mário de Andrade: "Essa forte, bela e problemática imagem do Brasil, que é Macunaíma [...], resolve-se em uma grande combinatória de feição mítica, cujos elementos parecem mover-se autonomamente, de modo anônino e impessoal". Pasta Júnior, José Antonio. "Tristes estrelas da Ursa-Macunaíma", in op. cit., pp. 30-31.

589 Lévi-Strauss, Claude. "A estrutura dos mitos", in Antropologia estrutural, Rio de Janeiro: Tempo Brasileiro, 2003, p. 241. Uma espécie de "degradação" do mito se verifica, por exemplo, na "carnavalização" da busca do Santo Graal em Macunaíma. Ver Souza, Gilda de Mello e. O tupi e o alaúde: uma interpretação de Macunaíma, São Paulo: Editora 34/Duas Cidades, 2003, pp 59-85.

${ }^{590}$ Pasta Júnior, José Antonio. Pompéia: a metafísica ruinosa d’O Ateneu, op. cit., p. 150.

${ }^{591}$ Lukács, Georg. A teoria do romance, São Paulo: Duas Cidades/ Editora 34, 2000, pp. 25-36.

592 Eagleton, Terry. Ideologia: uma introdução, São Paulo: Boitempo, 1997.
} 
ser negativos. Assim, no final de Macunaíma, por exemplo, "subir ao céu e virar estrela é caminho mitológico universal que soluciona estruturalmente o romance [...], mas que não resolve a problemática do herói incaracterístico; não o faz 'achar a verdade'" 593 . Em outras palavras, "Macunaíma resolve-se não se resolvendo", ou seja, "a fixação última de Macunaíma em estrela [...] oferece-nos algo como uma síntese que não supera ou, com licença da expressão, uma síntese negativa. [...] O brilho da estrela macunaímica é, antes de tudo, a fulguração de um malogro"594. Em carta de 1942, Mário de Andrade escreve, com melancolia, que "quando no fim Macunaíma [...] prefere ir viver o brilho ‘inútil' das estrelas, meus olhos se encheram de lágrimas" ${ }^{\text {995. A }}$ ascensão e a transfiguração de Macunaíma, que se seguem a sua auto-imolação final, não representam, portanto, a superação da finitude e a integração no Absoluto, como a ressurreição de Cristo $^{596}$, mas instauram uma espécie de má infinidade, ou seja, eternizam as contradições do "herói de nossa gente" - que são as próprias contradições fundamentais da formação histórica e cultural brasileira ${ }^{597}$.

Isso posto, voltemos às "Enfibraturas do Ipiranga", o oratório que encerra Paulicéia desvairada, e em cujo final também se encontram, como em Macunaíma, o sacrifício e o mau infinito, o martírio que não resgata.

Basicamente, as "Enfibraturas" constituem uma batalha antifonal entre modernistas e passadistas - estes, aliados à burguesia -, batalha que evolui rapidamente de exaltadas profissões de fé artísticas para um exasperado confronto de ordens, emitidas pelos "mestres do passado", contra insultos, lançados pelos "novos de São Paulo". Na obra de Mário, a crítica à burguesia paulistana tende com efeito a assumir a forma do insulto, como na famosa "Ode ao burguês", e tem a vibração da sacra fúria, do "rancor inebriante", dirigido contra o comerciante "de giolhos,/ cheirando religião e

\footnotetext{
${ }^{593}$ Lopez, Telê Porto Ancona. Macunaima: a margem e o texto, op. cit., p. 82.

594 Pasta Júnior, José Antonio. “Tristes estrelas da Ursa - Macunaíma”, in op. cit., pp. 27-28.

595 Andrade, Mário de. Cartas a um jovem escritor e suas respostas, op. cit., p. 24.

${ }^{596}$ Hegel, G. W. F. Curso de Estética: o Belo na Arte, op. cit., pp. 587-592.

${ }^{597}$ Pasta Júnior, José Antonio. “Tristes estrelas da Ursa - Macunaíma”, in op. cit., pp. 27-28.
} 
que não crê em Deus!"598. Em um conto de juventude, Mário representa Jesus em pessoa desembarcando em São Paulo na noite de Natal, invadindo o prestigiado baile do Trianon, uma "orgia escancarada", e fustigando violentamente a "comparsaria" de ricaços presente, revirando mesas e cadeiras como no episódio bíblico da expulsão dos vendilhões do templo, até ser agarrado e linchado pela multidão como um bode expiatório, vindo a expirar, estendido no chão, na posição de um crucificado $^{599}$. Nas "Enfibraturas do Ipiranga", os insultos coléricos proferidos pelos modernistas contra os passadistas e a burguesia também culminam no martírio da crucificação. No apogeu do conflito de palavras, após terem xingado seus adversários de "cães”, "boçais", "borras”, "infames", "burros", "bêbedos" etc., os modernistas proferem uma espécie de insulto superlativo, impronunciável, que visa a devastar o oponente - algo como a bomba atômica da linguagem -, e que é imediatamente seguido pela invocação da experiência sacrificial, na qual os jovens artistas se afirmam e se negam ao mesmo tempo - ou melhor, afirmam-se negando-se. O conjunto dos versos configura uma espécie de grito expressionista em que a máxima expressão da subjetividade coincide com $o$ aniquilamento da própria instância subjetiva e com a destruição completa do outro:

"Seus $! ! !$

(A maior palavra feia que o leitor conhecer)

Nós somos as Juvenilidades Auriverdes!

A passiflora! o espanto!... a loucura! o desejo!...

Cravos!... Mais cravos... para... a nossa... [cruz]" 600

Ao desfalecimento dos modernistas, segue-se um acalanto, algo como um epílogo da obra, em que os tons de uma consolação se misturam aos de uma lamentação, o conforto, ao desespero:

\footnotetext{
598 Andrade, Mário de. “Ode ao burguês”, in Paulicéia desvairada, op. cit., p. 89.

${ }^{599}$ Idem. "Conto do Natal” [1914], in Primeiro andar, in Obra imatura, op. cit., pp. 49-58

${ }^{600}$ Idem. "As enfibraturas do Ipiranga”, in Paulicéia desvairada, in op. cit., p. 113.
} 
“Chorai! Chorai! Depois dormi!

Venham os descansos veludosos

Vestir os vossos membros!... Descansai!

Diuturnamente cantareis e tombareis.

As rosas... As borboletas... Os orvalhos...

O todo-dia dos imolados sem razão...

Fechai vossos peitos!

Que a noite venha depor seus cabelos aléns

Nas feridas de ardor dos cutilados!

E enfim no luto em luz, (Chorai!)

Das praias sem borrascas, (Chorai!)

Das florestas sem traições de guaranis

(Depois dormi!)

Que vos sepulte a Paz Invulnerável!

Venham os descansos veludosos

Vestir os vossos membros... Descansai!

(quase a sorrir, dormindo)

Eu... os desertos... os Caíns... a maldição...

\section{LAUS DEO" 601}

Ainda que prenuncie, a certa altura, a ressurreição dos artistas e da natureza em um paraíso post mortem, a berceuse se esvai, em seu último verso, em palavras desesperadas, que apontam para a perpetuação da desgraça. Paulicéia desvairada termina portanto sem terminar, estendendo virtualmente ao infinito, por meio de suas palavras finais, as contradições que o eu-lírico procura ao longo do livro ressentir, até a

${ }^{601}$ Andrade, Mário de. “As enfibraturas do Ipiranga”, in Paulicéia desvairada, in op. cit., pp. 114-115. 
dilaceração, em seu próprio corpo, na intenção de libertar, por meio desse gesto extremo, sua poesia, sua cidade e a si mesmo.

Essa assunção das antinomias da matéria histórica no próprio corpo se expressa na imagem do Arlequim, em cujas vestes se reúnem as oposições paulistanas: "Arlequinal!... Trajes de losangos... Cinza e ouro.../ Luz e bruma... Forno e inverno morno..." ${ }^{902}$. Os contrastes da roupa do Arlequim são os próprios contrastes da metrópole: "a dualidade das cores que lutam no traje de losangos é a dualidade dos elementos que lutam na Paulicéia"603. Na mesma linha, escreveu Bastide: "Poesia feita de contrastes e de oposições, de pedaços e de cores diferentes - poesia do manto de Arlequim, afinal. Justaposição, sobre o mesmo tecido, dos nevoeiros de Londres e das rosas de verão, do Martinelli e das cabras silvestres"604.

$\mathrm{Na}$ medida em que incorpora os antagonismos da sociedade em sentido catártico - "Oh! minhas culpas e meus tresvarios!" -, o Arlequim marioandradino é a vítima sacrificial. Como toda vítima expiatória, ele se constitui simultaneamente, no livro, como o mesmo e o outro da cidade ${ }^{605}$. Por um lado, conforme notou muitas vezes a crítica, eu-lírico e São Paulo identificam-se ao longo de toda a obra: "Minha alma corcunda como a Avenida São João...”. O tumulto interior do escritor, que a poética desvairista propõe registrar de maneira imediata, é o próprio tumulto da cidade desvairada. O inconsciente, sede do "lirismo absoluto" em Paulicéia, chega a ser definido no "Prefacio Interessantíssimo" como uma "alma coletiva", como uma multidão de vozes que o poeta, à maneira de um possuído, deve transcrever ${ }^{606}$. Em carta de 1936, Mário recorda a escrita do livro: "Fui pro meu quarto, peguei num livro em branco já com umas escrituras ensaiantes, e escrevi numa folha: Paulicéia Desvairada e principiei escrevendo frases e poesias num estado palavra que quando recordo ele me

\footnotetext{
${ }^{602}$ Idem. "Inspiração", ibidem, p. 83. Conforme escreveu Jankélévich, o traje do Arlequim é uma imagem da "coincidência irracional dos contrários". Jankélévich, Vladimir. La musique et les heures, Paris: Seuil, 1988, p. 232.

${ }^{603}$ Lafetá, João Luiz. “A representação do sujeito lírico na Paulicéia desvairada”, in op. cit., p. 361.

${ }^{604}$ Bastide, Roger. Poetas do Brasil, São Paulo: Edusp, 1997, pp. 73-74.

${ }^{605}$ Girard, René. A violência e o sagrado, op. cit., pp. 338-339.

${ }^{606}$ Andrade, Mário de. "Prefácio Interessantíssimo", in Paulicéia desvairada, in op. cit., p. 67.
} 
parece que o desvairado era mesmo eu"607. As "paisagens do eu profundo", conforme a expressão usada no "Prefácio Interessantíssimo" para definir os versos do livro, são as próprias paisagens paulistanas, e vice-versa. Por outro lado, ao mesmo tempo em que se identifica à cidade, o eu-lírico dela se diferencia como o seu contrário. Assim, à ausência de poesia, às ambições generalizadas, ao catolicismo de fachada, à cautela burguesa, ao controle policial, à prostituição noturna, aos jardins afrancesados e à cultura tradicional, entre outras marcas de Paulicéia, o poeta opõe, ponto por ponto, muitas vezes com violência e sarcasmo, a celebração do lirismo, o desprezo pela ascensão social, a crença religiosa autêntica, a loucura artística, a defesa da liberdade, a pureza sexual, a linguagem brasileira e a proposta de renovação cultural. Em suma, em Paulicéia desvairada, o eu-lírico é a cidade mesma e seu contrário ao mesmo tempo: noutros termos, ele é o duplo da cidade ${ }^{608}$. Essa, justamente, é a condição da vítima expiatória em relação à comunidade ${ }^{609}$. A vítima deve ser idêntica ao sacrificante, para que possa substituí-lo, mas deve ser estranha a ele, para que este não compartilhe a sua sorte. Por isso, ela é escolhida entre os que se encontram à margem da ordem social, ou seja, ao mesmo tempo dentro e fora da sociedade - os pharmakoi -, posição marginal que o eu-lírico de Paulicéia ocupa em São Paulo: ele se define, conforme visto, como o "desafinado", o "contrabandista", o vagabundo que cantarola ao ar livre e é preso pela polícia; a cidade é sua "mãe" e sua "madrasta", ele pertence e não pertence a ela ${ }^{610}$.

Como vítima sacrificial, o poeta-Arlequim assume fisicamente as contradições da matéria histórica e, nesse movimento mesmo, pretende resolvê-las. Incorpora os crimes da cidade e, levando essa incorporação ao extremo, espera expiá-los: "Santa Maria dos olhos verdes, verdes,/ venho depositar aos vossos pés verdes/ a coroa de luz da minha loucura!", exclama o eu-lírico penitente, oferecendo à Virgem o princípio

\footnotetext{
607 Carta a Álvaro Moreyra. In Andrade, Mário de. Mário de Andrade escreve cartas a Alceu, Meyer e outros, op. cit., p. 51.

608 Vernant, Jean-Pierre. "A categoria psicológica do 'duplo"”, in Mito e pensamento entre os gregos, Difusão Européia do Livro/ Edusp, 1973, pp. 263-276.

609 “A vítima expiatória coincide com o duplo”. Girard, René. A violência e o sagrado, op. cit., p. 338.

${ }^{610}$ Andrade, Mário de. “Tu”, in Paulicéia desvairada, in op. cit., p. 98.
} 
mesmo de composição de seus poemas ${ }^{611}$. A redenção está mesmo no horizonte de Paulicéia desvairada. De acordo com as instruções de Mário de Andrade, a execução das "Enfibraturas do Ipiranga", o oratório que encerra o livro e culmina na crucifixão simbólica dos modernistas, se dá "na Aurora do Novo Dia”.

Vimos, contudo, que o sacrifício das Juvenilidades Auriverdes não redime a cidade. Ao contrário, embora prediga o advento dos "ouros do amanhã", das "floradas virginais", das "praias sem borrascas" e das "florestas sem traições", apesar de antever a "branca fecundação" realizada pelas lágrimas e pelas almas dos artistas imolados "Ponde os lábios na terra! Ponde os olhos na terra!/ Vossos beijos finais, vossas lágrimas primeiras/ Para a branca fecundação!/ Espalhai vossas almas sobre o verde!” -, apesar disso, o acalanto final de Paulicéia se encerra, após o adormecimento - ou, a morte sacrificial - dos modernistas, com a afirmação dos campos estéreis, das traições nefandas, da maldição perpétua: "Eu... os desertos... os Caíns... a maldição...". Dispostas na forma do verso harmônico, as palavras nefastas do último verso de Paulicéia "ficam vibrando", conforme escreve Mário de Andrade sobre suas harmonias poéticas. A obra acaba sem acabar, perenizando a má infinidade da culpa irremissível em um dos poemas do livro, a cidade é comparada a Lady Macbeth -, culpa que o lirismo sacrificial de Paulicéia pretendia expurgar. O trágico verso final do livro exprime, portanto, o fracasso do desvairismo. Com efeito, ele é recitado, assim como todo o acalanto, por Minha Loucura, personagem alegórica que representa, na poética desvairista, o próprio "estado lírico", a mediação por que o poeta apreende a matéria histórica e a converte em poesia.

A maldição que pesa sobre esse lirismo decorre de que ele participa, no sentido forte - mágico-religioso - do termo ${ }^{612}$, das contradições que procura figurar. Mais precisamente, a má-infinidade a que a poesia de Paulicéia está condenada prende-se ao fato de que a figuração poética dos problemas históricos, segundo a própria lógica

${ }^{611}$ Idem. "Religião", in Paulicéia desvairada, in op. cit., p. 101.

612 Brühl, Lévy. Les fonctions mentales dans les sociétés inférieures, Paris: Felix Alcan, 1910. Assim como outros modernistas, Mário de Andrade conhecia as idéias de Lévy Brühl sobre o pensamento mágico-religioso e a chamada "lei da participação". Esta, inclusive, era considerada por Mário "uma conquista definitiva" das ciências humanas. Lopez, Telê Porto Ancona. Mário de Andrade: ramais e caminho, op. cit., p. 99. 
interna do desvairismo, se dá justamente por meio do aprofundamento, ao extremo, da participação da poesia nas antinomias da cidade de São Paulo, no apogeu da economia cafeeira. No horizonte do esquema teórico do "Prefácio Interantíssimo", encontra-se a supressão das mediações entre a cidade e o poeta, o poeta e o poema, o poema e a cidade $^{613}$. A loucura ruinosa da metrópole na periferia do capitalismo é apreendida na medida em que o eu-lírico se torna ele próprio, por inteiro e sem distância, essa loucura mesma. Essa identificação que caracteriza as relações entre o eu-lírico e a cidade é de natureza mágico-religiosa: São Paulo inspira o poeta, o possui, propiciando-lhe o enthousiasmós - "São Paulo! comoção da minha vida...", exclama o "trovador" paulistano, invocando a musa à maneira dos antigos, no verso de abertura do livro. Assim, segundo a boa crítica, o poeta funde-se com a cidade ${ }^{614}$ - como nas extáticas núpcias místicas, diríamos nós:

“Paulicéia, minha noiva... Há matrimônios assim...

Ninguém os assistirá jamais! As permanências de ser um na febre!"’15.

Por sua vez, também a relação entre o poeta e o poema tem, no contexto de uma defesa do "lirismo imediato", a marca da continuidade mágica ${ }^{616}$. Roberto Schwarz escreveu que, na poética de Paulicéia desvairada, "mesmo as resistências do medium expressivo, a linguagem estruturada, devem ser rompidas. [...] $\mathrm{O}$ impulso [subconsciente, portanto a "impulsão lírica", segundo o desvairismo] ficaria como que fisicamente retido na matéria poética, sendo liberado por ocasião da leitura. A experiência da poesia abandonaria o nível simbólico para fazer-se, absurdamente, em forma de obscura transferência energética" ${ }^{\prime 17}$. Sendo assim, a cadeia mágica de

\footnotetext{
613 De modo que, em sua capa, que reproduz a roupa do Arlequim, "o livro exibe-se como se fosse a própria cidade". Lopez, Telê Porto Ancona. Mariodeandradiando, op. cit., p. 23.

${ }^{614}$ Idem. Mário de Andrade: ramais e caminho, op. cit., p. 215.

${ }^{615}$ Andrade, Mário de. "Tristura”, in Paulicéia desvairada, in op. cit., p. 90.

${ }^{616}$ Mauss, Marcel. "Esboço de uma teoria geral da magia”, in op. cit., pp. 99-104

${ }^{617}$ Schwarz, Roberto. “O psicologismo na poética de Mário de Andrade”, in op.cit., p. 16, grifo meu.
} 
identificações propiciadas pelo lirismo estende-se ao próprio leitor: "Canto é agente simpático: faz renascer na alma dum outro [...] o mesmo estado lírico provocado em nós por alegrias, sofrimentos, ideais", escreve Mário ${ }^{618}$. Noutros termos, a poesia encanta o leitor, à semelhança do canto órfico: "farei com que as próprias pedras se reunam em muralhas à magia do meu cantar". Também por isso, a linguagem de Paulicéia procura assumir estruturas musicais, tendo em vista as "afinidades eletivas" entre a música e a magia, afinidades que Mário de Andrade conhecia tão bem ${ }^{619}$, e que remontam a um vínculo originário, que se exprime na palavra carmen, que designava uma fórmula mágica e um canto ao mesmo tempo ${ }^{620}$. De acordo com o pensamento platônico, o canto, ou a música em geral, devido a suas virtudes mágicas, penetra a alma do ouvinte e a faz vibrar em uníssono com a alma do poeta ${ }^{621}$. Nessa linha, Mário de Andrade escreve a Manuel Baneira que os grandes artistas são "os que ecoam nos outros", enquanto Bandeira lhe diz que os poemas de Paulicéia desvairada, ao serem declamados por Mário em sua presença, "deixaram em mim a ressonância de inumerávais harmônicos"622. Em Paulicéia o leitor é chamado a reviver, como nos ritos, os poemas que o poeta, por sua vez, pretende ter vivido, mais do que escrito. Por isso, Mário adverte: “Quem não souber cantar não leia Paisagem n 1. Quem não souber urrar não leia Ode ao Burguês. Quem não souber rezar não leia Religião"623. Às avessas, o lirismo desvairista é um lirismo para iniciados.

Em todos os níveis compositivos da obra que inaugura nosso modernismo literário, portanto, a dialética entre o particular e o universal, entre o indivíduo e a sociedade, entre a poesia e a história e entre a poesia e o leitor tende a converter-se em participação mágico-religiosa. Essa participação, como de regra, possui em Paulicéia

\footnotetext{
${ }^{618}$ Andrade, Mário de. "Prefácio Interessantíssimo", in op. cit., p. 76.

619 “A música é uma parceira instintiva, imediata e necessária, tanto das práticas da alta magia das civilizações espirituais, como da baixa magia das civilizações naturais". Idem. Música de feitiçaria no Brasil, op. cit., p. 23.

620 Sobre as relações entre a música e a magia, ver Combarieu, Jules. La musique et la magie, Genebra: Minkoff, 1978.

${ }^{621}$ Moutsopoulos, Evanghélos. La musique dans l'oeuvre de Platon, op. cit., p. 247.

${ }^{622}$ Andrade, Mário de. Correspondência - Mário de Andrade \& Manuel Bandeira, pp. 69, 545.

${ }^{623}$ Idem. "Prefácio Interessantíssimo", in op. cit., p. 76.
} 
desvairada uma natureza sacrificial, que se revela em imagens, conforme visto, mas que também está no núcleo da poética do livro: de acordo com o desvairismo, o eu-lírico se constitui na loucura, perdendo-se a si mesmo, sendo possuído pela cidade, assim como a vítima expiatória é possuída pelo sagrado na consumação do sacrifício.

Considerando-se que sacrifício é barbárie, a participação que está em jogo no desvairismo, como notou José Antonio Pasta Júnior acerca de muitas de nossas obras capitais, tem o caráter do que Adorno chamou de methexis [participação] nas trevas ${ }^{624}$. No poema "Religião", o eu-lírico se apresenta à Virgem como pertencente ao grupo dos "Jamais Iluminados"625. Ele participa das trevas paulistanas: São Paulo, com efeito, bebe "de longe em longe uma chávena da treva bem forte", diz um verso do livro626. Dessa treva, que é o próprio café paulista, o sangue da modernização conservadora da cidade, o eu-lírico de Paulicéia desvairada se embriaga. A crítica e a negação da sociedade confundem-se com a fascinação e o gozo que os paradoxos da matéria social despertam: "Gosto dos teus desejos de crime turco/ E das tuas ambições retorcidas como roubos!”, declara o poeta à cidade arlequinal ${ }^{627}$. O grito que atravessa a obra de ponta a ponta, rasgando as brumas impressionistas das "harmonias poéticas", é portanto um grito de dor superlativa, mas também de máximo prazer. A poesia de Paulicéia desvairada reitera as contradições históricas no movimento mesmo em que as configura: ela celebra o sacrifício, não o submete à distância que o colocaria em perspectiva crítica, ou seja, como fenômeno vinculado à matéria social, mas que deve, como esta, ser negado. Ao contrário, Mário de Andrade espera liberar a história e a cultura entranhando-se nas estruturas sociais vigentes, incorporando-as até as últimas conseqüências. Desse modo, por um lado, leva os antagonismos paulistanos ao esgotamento; por outro, entretanto, os reatualiza. O sacrifício, experiência-limite dessa capacidade desejada de ressentir as contradições da sociedade, reproduz em sua

\footnotetext{
624 “Uma conversa com José Antonio Pasta Júnior”, in Sinal de Menos, no 4, São Paulo: 2010, pp. 6-7.

${ }^{625}$ Idem. "Religião", in op.cit., p. 97.

${ }^{626}$ Andrade, Mário de. "Tu”, in Paulicéia desvairada, in op cit., p. 98

${ }^{627}$ Idem. Ibidem, p. 97.
} 
dinâmica ruinosa a má-infinidade que está no coração da lógica da modernização conservadora.

A natureza sacrificial do lirismo desvairista se consuma no sacrifício da linguagem, implicado na transfiguração da palavra em música, transfiguração que está no horizonte das propostas estéticas do "Prefácio Interessantíssimo". Vimos que para representar as dualidades paulistanas Mário de Andrade é levado a renunciar, em grande medida, ao que ele chamava de valor inteligível das palavras, ou seja, a qualidade significativa dos vocábulos, que constitui a seu ver a essência da linguagem ${ }^{628}$. No importante "Ensaio sobre a música brasileira", Mário enfatiza as dificuldades de registrar com precisão, por escrito, a música popular brasileira, uma vez que o ritmo, a harmonia, a melodia e o próprio timbre são quase sempre ambíguos nessa tradição ${ }^{629}$. A metrópole na periferia do capitalismo, onde as contradições brasileiras se concentravam violentamente, não oferecia menores dificuldades ao escritor que a procurava apreender por meio das palavras. Embora se configure como um movimento gozoso e libertário, a tendência da linguagem delirante de Paulicéia desvairada a tornar-se puramente musical relaciona-se ao desespero do escritor em relação às possibilidades de resolver, por meio de sínteses, as aporias que constituíam a sociedade e a cultura no Brasil - é em função de contradições históricas profundas que "a poesia, para Mário, deve [...] tocar as fronteiras da música, deve ser música”, conforme escreveu um crítico em $1946^{630}$. Mário quer dizer o específico, e no entanto deve recorrer à música, que a seu ver é "vaguíssima" para a consciência ${ }^{631}$. Ele deseja especificar a matéria local, captar a "nossa exatidão", nas palavras do "Carro da Miséria", mas somente crê alcançá-lo por meio da expressão musical, por si mesma incapaz, ele diz, de exprimir exatamente qualquer coisa, quer do mundo exterior, quer do mundo interior ${ }^{632}$.

\footnotetext{
628 Andrade, Mário de. Introdução a Estética musical, op. cit., p. 46. Ver também Sapir, Edward. Le langage: introduction à l'étude de la parole, Paris: Payot, 2001, pp. 9-32

${ }^{629}$ Andrade, Mário de. Ensaio sobre a música brasileira, op. cit.

${ }^{630}$ Haddad, Jamil Almansur. "A poética de Mário de Andrade”, in Revista do Arquivo Municipal, CVI, São Paulo: jan/fev de 1946, p. 123.

${ }^{631}$ Idem. Introdução à Estética musical, op. cit., pp. 37-51.

${ }^{632}$ Idem. "Romantismo musical", in O baile das quatro artes, op. cit., pp. 37-66.
} 
Sobretudo, portanto, a passagem para a música tem uma natureza sacrificial porque implica a renúncia ao sentido - “o som musical não tem sentido algum”633 -, ao passo que é justamente o sentido da formação histórica nacional - em sua versão paulistana, no caso de Paulicéia - que o poeta, ao realizar essa passagem, pretende apreender e transmitir. Sem abusar do gosto do paradoxo, e levando as propostas de Mário até o fim, pode-se dizer que a linguagem capaz de dar forma às contradições da sociedade brasileira se constitui, de acordo com o desvairismo, por meio de sua supressão como linguagem. N'A escrava que não é Isaura [1924], ensaio em que reformula as propostas do "Prefácio Interessantíssimo", Mário recorda, realizando uma autocrítica, o sacrifício praticado em Paulicéia: "A musicalidade encanta e sensualiza grande parte da poesia modernista. É um dos maiores defeitos de 'Paulicéia desvairada'. Há musicalidade musical e musicalidade oral. Realizei ou procurei realizar muitas vezes a primeira com prejuizo da clareza do discurso"634.

Ademais, a passagem da palavra na música significa, no limite, segundo a estética de Mário, uma passagem da palavra em seu ganz andere, isto é, em seu inteiramente outro: "É coisa bem sabida que em todos os tempos o canto viveu em luta com a poesia. Música e poesia têm exigências e destinos diferentes, que põem em [...] irreconciliável conflito a voz falada e a voz cantada". Mário dirá que o canto quer a "imediata intensidade fisiológica do som musical", enquanto a palavra quer “inteligibilidade". "Não haverá talvez conflito mais insolúvel”, conclui o escritor ${ }^{635}$. Nesse quadro, palavra e música se opõem como o profano e o sagrado, e a passagem da palavra na música, como toda passagem do mesmo no seu absolutamente outro, é uma passagem sacrificial.

\footnotetext{
${ }^{633}$ Idem. "Terapêutica musical”, in Namoros com a medicina, Belo Horizonte: Itatiaia,1980, p. 14.

634 Idem. A escrava que não é Isaura, in op. cit., p. 260. A abdicação do "significado inteligível" da linguagem não consistia, portanto, uma renúncia menor para Mário de Andrade. Em carta de 1925 a Manuel Bandeira, o autor das Danças chega a declarar: "Agora meu desejo é esse: construir o poema pau, o poema que não tem nenhuma excitação exterior [...]. O poema poesia construído com pensamento condicionando o lirismo [...]. Quero construir o poema [...] que não carece de ser recitado, ao contrário que perde quando recitado (o tempo dos rapsodos e dos menestréis já passou) o poema que carece ser lido e entendido". Todavia, uma vez que o Brasil, segundo o escritor, "arromba toda concepção que a gente faça dele", a poesia de Mário retornaria logo e sempre, até o fim, à "doce música", que dissolve contradições. Idem. Correspondência - Mário de Andrade \& Manuel Bandeira, op. cit., p. 263; Idem. "Sinhô" [1929], in Táxi e crônicas do Diário Nacional, op. cit., p. 84.
} 
O conhecido poema "O trovador", de Paulicéia desvairada, tem como assunto as dualidades principais, sob a perspectiva dos modernistas, que marcam o poeta no Brasil: nacional e europeu, primitivo e moderno, o trovador brasileiro se vê enredado na contradição histórica de cantar em língua estrangeira - como um "desterrado em sua terra", diríamos, parafraseando a formulação de Sérgio Buarque de Holanda sobre o caráter importado, portanto artificial, das nossas instituições ${ }^{636}$. O problema da falta de um meio expressivo correspondente às condições brasileiras, problema a que Mário dedicou grande parte de sua atividade intelectual, é o núcleo do poema, constitui o seu tema ${ }^{637}$. Não é à toa que o aspecto sonoro das palavras, valorizado em toda Paulicéia, possui em "O trovador" uma importância especial, de maneira que a linguagem se transfigura ao longo do poema, pouco a pouco, em pura música, para dissolver-se, enfim, na nebulosa das reticências, que representam o ecoar dos sinos, e no silêncio, antes de precipitar-se em um grito ao mesmo tempo sarcástico e desesperado:

\section{“O TROVADOR}

Sentimentos em mim do asperamente

dos homens das primeiras eras...

As primaveras de sarcasmo

intermitentemente no meu coração arlequinal...

Intermitentemente...

Outras vezes é um doente, um frio

na minha alma doente como um longo som redondo...

Cantabona! Cantabona!

Dlorom...

\footnotetext{
${ }^{636}$ Holanda, Sério Buarque de. Raizes do Brasil, op. cit., p. 31.

${ }^{637}$ Mário de Andrade distinguiu assunto e tema, em poesia, nos seguintes termos: "O assunto, em poesia, tem de ser o que é a melodia infinita em música, um elemento geral e genérico, dentro do qual os movimentos do ser vagueiam entre descaminhos, encruzilhadas, quedas em abismos [...]. Ao passo que o tema em poesia é a restrição do assunto a um ponto só da sua caminhada, da mesma forma que em música é um elemento curto retirado da melodia". Andrade, Mário. "Castro Alves", in Aspectos da literatura brasileira, op. cit., p. 140.
} 
Sou um tupi tangendo um alaúde!"

Pode-se dizer que o primeiro bloco do poema forma uma espécie de "nebulosa eloqüente em que as próprias palavras são valores imensos cósmicos de música", como Mário se referiu certa vez aos cantos dos cantadores populares ${ }^{638}$. A predominância das sonoridades anasaladas, organizadas em um conjunto riquíssimo de rimas internas, a presença recorrente das reticências, nas quais os versos se esvaem, e a reprodução da ressonância dos sinos - "Dlorom..." - concorrem para a constituição de uma espécie de nuvem de vibrações sonoras em suspensão, onde as antíteses que dividem o eu-lírico se desfazem em fumaça ${ }^{639}$. A oposição conceitual entre as "primeiras eras" (o antigo) e as "primaveras" (o novo), por exemplo, dissolve-se na semelhança das sonoridades das duas expressões, assim como o "sarcasmo" e sua "intermitência" perdem o gume na melodia lenta, longa, solene e melancólica de "intermitentemente...". A batida repentina e violenta dos sinos - "Cantabona! Cantabona!" -, com suas oclusivas muito marcadas e seus pontos de exclamação, perturba o fluxo contínuo das palavras, mas não fratura a paisagem sonora do poema. Nas nasais dobradas - "Cantabona" - ressoam as "harmonias" dos versos anteriores, prolongando a musicalidade do conjunto. Em especial, a tônica - bo(n) - não apenas dá continuidade ao "longo som redondo", como constitui, em função da consoante $b$, uma espécie de apogeu festivo dessa sonoridade. Com efeito, esse verso constitui o ápice do movimento progressivo, que se verifica desde o início do poema, de transformação das palavras em entidades musicais. É em “Cantabona! Cantabona!” que se opera a passagem da linguagem significativa para a música: ao mesmo tempo em que designa o nome de um tipo específico de sino, “Cantabona!” é também, no poema de Mário, a onomatopéia do repique festivo desses

${ }^{638}$ Idem. "Vida do Cantador (5 Lição)" [1943], in Vida do cantador, op. cit., p. 59.

${ }^{639} \mathrm{~A}$ ênfase dada pelo autor às nasais, em um poema que denuncia a inadequação da língua portuguesa às necessidades expressivas do poeta brasileiro, talvez não seja casual. De acordo com Mário de Andrade, a nasalidade é uma marca da fala no Brasil: "a voz brasileira tem uma timbração nasal muito especificamente sua, muito característica, que a mim me parece deliciosa". Andrade, Mário de. "Os compositores e a língua nacional" [1937], in Aspectos da música brasileira, Aspectos da música brasileira, Belo Horizonte/Rio de Janeiro: Villa Rica, 1991, p. 41. 
sinos. Ou seja, a palavra funciona simultaneamente como um signo lingüístico e como um elemento puramente musical, realizando-se desse modo a transição para a musicalidade livre de "Dlorom...", termo que nada significa, mas somente reproduz a ressonância do som dos sinos, do "longo som redondo" que é também a própria "alma doente" do poeta.

Em suas cartas, diários e poesias, Mário com freqüência afirma "vibrar" com as coisas - obras de arte, fenômenos naturais, ambientes populares, relações amorosas etc. -, como se fosse, ele mesmo, um instrumento musical, em que ressoam a sociedade, a história e a natureza brasileiras: "Tudo retumba tanto em mim!", ele exclama, em carta de 1926, a Drummond ${ }^{640}$. Ao assumir, como se o fizesse de modo físico, a condição de instrumento musical, em especial a dos instrumentos de percussão, Mário de Andrade se coloca também na posição de vítima sacrificial.

As afinidades profundas entre a vítima expiatória e o instrumento de música não se reduzem ao fato, bastante significativo todavia, de que tambores e cordas sejam feitos com tripas e peles de animais. Como se sabe, o próprio Mário o afirma, a grande maioria das culturas primitivas e antigas atribuía uma origem divina à música: "Ninguém considera a música como criação humana. Há quase unanimidade entre primitivos e Antigos no atribuir aos deuses a invenção da arte musical" ${ }^{441}$. Essa atribuição, segundo o escritor, verifica-se por toda parte entre os índios do Brasil, para os quais a música "faz parte constantemente das forças sobrenaturais" ${ }^{642}$. Nesses casos, os sons e o ritmo, as melodias e as harmonias emitidas pelos instrumentos são consideradas a voz mesma dos deuses, de maneira que, especialmente nos ritos, quando as entidades mitológicas se tornam presentes entre os homens, os instrumentos tocados pelos músicos são tidos como o lugar em que os deuses se instalam ou, no limite, como os próprios deuses ${ }^{643}$. Mário de Andrade conhecia bem esse tipo de identificação: "Não é raro que um instrumento seja tido como um deus por si mesmo", registra o escritor, ao

\footnotetext{
640 Andrade, Mário de. A lição do amigo, op. cit., p. 67.

${ }^{641}$ Idem. Música de feitiçaria no Brasil, op. cit., p. 44.

${ }^{642}$ Idem. Ibidem, pp. 46-47.

${ }^{643}$ Rouget, Gilbert. La musique et la transe, op. cit., pp. 219-221.
} 
tratar da música de feitiçaria no Brasil ${ }^{644}$. Ora, os deuses são as vítimas sacrificiais por excelência. De acordo com Mauss, "é no sacrifício de uma pessoa divina que a noção do sacrifício chega à mais alta expressão" ${ }^{645}$, e pode-se mesmo dizer que todo sacrifício, a rigor, é o sacrifício do deus, pois que a vítima deve estar, no instante da imolação, inteiramente possuída pelo sagrado. Nos ritos mágico-religiosos, portanto, ao golpear os tambores, tanger os sinos, repinicar as violas etc., ao ferir seus instrumentos, o músico golpeia ou fere nada mais, nada menos, que o próprio deus.

A identificação entre o instrumento musical, o sagrado e a vítima sacrificial se verifica, por exemplo, no candomblé, em que os tambores "bebem" o sangue de um animal sacrificado, tornando-se desse modo sagrados e aptos para serem usados nos ritos $^{646}$. Na mesma linha de associações, nos rituais de possessão, golpear os instrumentos é ao mesmo tempo golpear os participantes, que entram em transe sob o efeito desses golpes. A percussão, diz Mário, “mortifica” os possuídos ${ }^{647}$. Para o escritor brasileiro, a natureza mortífera simbólica dos instrumentos musicais remonta a uma origem em que estes serviam para causar a morte realmente: "Dizem os arqueólogos e etnógrafos que o arco primitivo foi ao mesmo tempo instrumento de morte e de música. Desferindo a flecha, o arco servia ao homem para matar mas dedilhado e vibrante servia para dar sons musicais" $" 648$. Em sentido análogo, de acordo com um estudioso do assunto, nas práticas de tarantulismo, no momento da possessão, o violinista aproximase de tal forma do participante que seu arco parece ter por violino o próprio corpo convulso do possuído, o qual, conforme dito, é uma variante da vítima expiatória ${ }^{649}$.

\footnotetext{
${ }^{644}$ Andrade, Mário de. Música de feitiçaria no Brasil, op. cit., p. 36.

645 Hubert, Henri; Mauss, Marcel. "Ensaio sobre a natureza e a função do sacrifício", in Mauss, Marcel. Ensaios de sociologia, op. cit., p. 209. Ver também Frazer, James George. Le Rameau d'Or, op. cit.

${ }^{646}$ Bastide, Roger. Le candomblé de Bahia (rite Nagô), Paris: Plon, 2000, pp. 48, 119-120.

${ }^{647}$ Andrade, Mário de. Música de feitiçaria no Brasil, op. cit., p. 35.

${ }^{648}$ Idem. Aspectos da música brasileira, op. cit., p. 32.

649 Rouget, Gilbert. La musique et la transe, op. cit., pp. 218. O tarantulismo, como se sabe, é uma afecção nervosa convulsiva, popularmente atribuída à picada da aranha (tarântula), e que se manifesta pelo desejo incontrolável de dançar. Ao mesmo tempo em que expressa a doença, a dança é tida como o meio de eliminar o veneno. As práticas de tarantulismo constituem uma espécie de ritualização dessa dança, de modo a provocar ou acelerar a eliminação do veneno.
} 
Sob essa perspectiva, a execução musical aparece como um simulacro do assassinato ritualístico ${ }^{650}$. Não é à toa que, ao afirmar o sacrifício da perenidade de sua obra em favor da utilidade transitória de seu trabalho, Mário compara-se a um sino que badala o momento histórico brasileiro: "Não tenho a mínima pretensão de ficar. O que eu quero é viver meu destino, é ser badalo do momento. Minha obra toda badala assim: 'Brasileiros, chegou a hora de realizar o Brasil'" ${ }^{651}$. Na mesma linha, como se viu, ele descreve o êxtase místico que sofreu na Ilha de Marajó, experiência de inequívoca conotação sacrificial, como um "estardalhaço de mil sinos tocando". O eu-lírico de "O trovador", por sua vez, equipara sua alma ao som dos sinos no contexto da conversão sacrificial da palavra em música, conversão por meio da qual ele anseia obter a linguagem capaz de formular a experiência da matéria local, de modo a superar, no sentido dialético do termo, as contradições brasileiras que marcam sua subjetividade primitiva e moderna, indígena e européia.

Mário de Andrade concebia a "língua brasileira" como uma língua musical. Nos esboços da Gramatiquinha da fala brasileira que pretendia escrever, ele adverte para a natureza heteróclita e contraditória da formação da linguagem no Brasil, esse “monstrengo político", de "corpo mal costurado", onde "existe uma língua oficial emprestada", que não é falada, e "um poder de outras línguas" faladas por minorias variadas. Por isso, diz o escritor, a "fala brasileira", se vier a se constituir um dia, "nunca será pura nem unida, dados os erros sociológicos que formam a pseudonação"652. Mário identifica, não obstante, uma característica brasileira no campo lingüístico - a "verdadeira musicalidade" do falar no país: "o caipira quando fala,

\footnotetext{
${ }^{650}$ Attali, Jacques. Bruits, op. cit., pp. 37-74. Segundo o argumento de Attali, baseado na teoria social de René Girard, o caráter sacrificial da música decorre de que ela consiste, essencialmente, em dar forma e sentido à violência do ruído. A música absorve e ritualiza a violência generalizada e desordenada do barulho, canalizando-a e transformando-a em harmonia: "A função fundamental da música é a de mostrar que a violência é controlável, portanto que a sociedade é possível. Mais precisamente, o barulho é uma arma e a música é a sua formalização, a sua domesticação em um simulacro do assassínio ritual, [...] metáfora do sacrifício fundador de toda ordem social". Idem. Ibidem, pp. 27, 43.

${ }^{651}$ Andrade, Mário de. Correspondência - Mário de Andrade \& Manuel Bandeira, pp. 146-147.

652 Pinto, Edith Pimentel. A Gramatiquinha de Mário de Andrade: texto e contexto, São Paulo: Duas Cidades, 1990, pp. 321-324. Mário apresenta uma opinião diferente em "Fala brasileira - I" [1929], in Táxi e crônicas no Diário Nacional, op. cit., pp. 90-92.
} 
sobretudo o mulato, canta" ${ }^{653}$. A musicalidade aparece como uma constância em meio à diversidade e à contradição, o que correspondia a uma realidade social: embora considere que o povo brasileiro ainda seja um "simulacro de povo", um povo sem caráter definido, Mário nota que "o Brasileiro é um povo esplendidamente musical”654. “Grande número de viajantes estranhos atestaram a propensão do brasileiro para a música", observa, concluindo que "Von Weech afirma que 'a musicalidade é inata ao povo' [do Brasil]" 655 . Nessa linha, Mário escreve a Manuel Bandeira: "O que me surpreende no caso brasileiro é que literariamente, politicamente, sociologicamente e uma porção de outros mentes, mal nos distinguimos como nacionalidade; e no entretanto musicalmente temos nacionalidade marcante" ${ }^{956}$. A língua brasileira deve nascer, pois, sob o signo da música, como a escrita de Macunaíma, que é canto e cachiri, ou seja, melodia que embriaga, organizada por estruturas musicais ${ }^{657}$, lembrando desse modo, em certa medida, a linguagem original, carregada de natureza, imaginada por Rousseau ${ }^{658}$.

Inversamente, em um ensaio de 1939 sobre Castro Alves, Mário sustenta que a redução das palavras a seu sentido exato é própria da sociedade burguesa européia, uma prática ligada ao império da racionalidade instrumental: “O sentido como o pensamento lógico são expressões de burguesice. A burguesia renega as vaguezas, as evanescências; é anti-musical por excelência", e transforma a linguagem em "escultura" ${ }^{659}$. Na tradição da lírica, o apogeu da redução da palavra a sua "objetividade escultórica” ocorre na poesia do Parnasianismo, considerada pelos modernistas uma literatura importada da

${ }^{653}$ Idem. Ibidem, p. 416.

${ }^{654}$ Andrade, Mário de. Ensaio sobre a música brasileira, op. cit., 56. Em outro livro, ele observa: “

${ }^{655}$ Idem. Pequena história da música, op. cit., p. 179.

${ }^{656}$ Idem. Correspondência - Mário de Andrade \& Manuel Bandeira, op. cit., p. 310.

657 “Então o pássaro principiou falando numa fala mansa, muito nova, muito! que era canto e que era cachiri com mel-de-pau, que era boa e possuía a traição das frutas desconhecidas do mato". Andrade, Mário de. Macunaíma, o herói sem nenhum caráter, op. cit., p. 168. Sobre as estruturas musicais do livro, ver Souza, Gilda de Mello e. O tupi e o alaúde: uma interpretação de Macunaíma, op. cit, pp. 9-29.

${ }^{658}$ Rousseau, Jean-Jacques. Essai sur l'origine des langues, op. cit., pp. 59-145.

${ }^{659}$ Andrade, Mário de. “Castro Alves”, in Aspectos da literatura brasileira, op. cit., p. 139. 
França e descolada da matéria brasileira ${ }^{660}$. Como se sabe, Paulicéia desvairada é uma obra movida por um forte espírito anti-burguês, assume a loucura como princípio de composição, postula uma reação à poética parnasiana - ainda que os poemas conservem marcas dessa poética - e realiza uma crítica violenta à prática da imitação cultural, em especial da imitação da cultura francesa belle époque em São Paulo. O livro se volta para a matéria local e procura apreender as duplicidades do progresso no contexto brasileiro, em especial as combinações contraditórias de padrões burgueses e préburgueses, cosmopolitas e provincianos, que estruturavam a sociedade paulistana no início do decênio de 1920. Nessa linha, Mário defende, no "Prefácio", o emprego da "língua brasileira", que ele afirma ser "uma das mais sonoras" que existem. A proposta desvairista de que a poesia assuma como seu paradigma a música, em oposição à escultura, deve ser compreendida nesse contexto de tentativa de expressão do específico nacional.

Em Clã do Jabuti [1927], o propósito nacionalista, incipiente em Paulicéia, torna-se mais abrangente, e a incorporação da música se aprofunda. "Livro estupendamente brasileiro", como disse Bandeira ${ }^{661}$, em que Mário de Andrade procura reunir simbolicamente os homens e as culturas das várias regiões do Brasil, Clã do Jabuti é inteiramente composto, salvo duas ou três exceções, por poemas calcados em formas musicais - a moda, o côco, a toada, o rondó, o samba, a síncopa, o noturno e o acalanto. A relação entre expressão brasileira e expressão musical não se limita, contudo, ao plano das formas, e alcança o plano da própria linguagem. Logo no poema de abertura do livro, o poeta anuncia que seu canto se produz em "língua brasileira": "Brasil.../ Mastigado na gostosura quente do amendoim.../ Falado numa língua curumim/ De palavras incertas num remeleixo melado melancólico.../ Saem lentas frescas trituradas pelos meus dentes bons..."662. A palavra brasileira é "incerta", isto é, assim como os motivos musicais, não tem significado preciso. Assim, quando o eulírico procura caracterizá-la, a linguagem praticamente se transforma em um puro

\footnotetext{
${ }^{660}$ Idem. "Parnasianismo" [1938], in O empalhador de passarinho, op. cit., pp. 13-14.

${ }^{661}$ Idem. Correspondência - Mário de Andrade \& Manuel Bandeira, op. cit., p. 226.

${ }^{662}$ Idem. “O poeta come amendoim”, in Clã do Jabuti, in Poesias completas, op. cit., p. 126.
} 
elemento rítmico-melódico - "remeleixo melado melancólico" -, processo recorrente nos poemas do livro. Volta e meia, a linguagem de Clã do Jabuti encontra-se na iminência de se converter em música - "Fanfarras fanfarrans/ fenferrens/ finfirrins...", "Maravilhas de milhares de brilhos vidrilhos", "Esmeraldas esmeraldas esperanças!". Por fim, o livro, que contém uma série de referências à magia do canto, se "encerra" com a repetição ad infinitum, encantatória, de versos de ninar, por meio da qual as palavras gradualmente perdem seu valor semântico e se tornam valores musicais: "Brasileiro, dorme./ Brasileiro, dorme./ Brasileiro... dorme.../ Brasileiro... dorme...".

No caso de Paulicéia desvairada, a defesa da utilização musical da palavra se dá nos quadros de uma profissão de fé do "lirismo absoluto", definido por Mário nos seguintes termos: "lirismo absoluto, quase automático e sobrerrealista, intelectualmente incompreensível, ou melhor, paralógico [...], os tais versos de louco" ${ }^{663}$. Ao decretar a obediência incondicional às exigências de "Dom Lirismo", de modo que se cristalize nos poemas "a naturalidade livre do lirismo objetivado", a poética desvairista defende que a poesia, produzida em condições "agônicas", ultrapasse a natureza referencial da linguagem e se torne música.

Nesse sentido, o lirismo absoluto marioandradino assemelha-se ao canto novo, produzido pelos cantadores nordestinos no momento de paroxismo da inspiração criativa, que fascinava Mário de Andrade. Nele, diz o autor de Macunaíma, o cantador “descreve de maneira moderníssima e impressionante, $[\ldots]$ pouco se amolando com a claridade do sentido. O que o embala é a música. As palavras pra ele não passam de valores musicais" 664 . O canto novo é uma improvisação desenfreada com base em um conjunto extenso de formas tradicionais retidas na memória, uma espécie de turbilhão

\footnotetext{
${ }^{663}$ Idem. A lição do amigo, op. cit., p. 153.

${ }^{664}$ Idem. "Chico Antônio" [1929], in Vida do cantador, op. cit., p. 169. Vale lembrar que, para Nietzsche, a natureza "musical" da palavra é própria de toda canção popular, o que está no horizonte, também, do pensamento de Mário de Andrade: "Na poesia da canção popular, vemos a linguagem empenhada ao máximo em imitar a música: [...] a palavra, a imagem, o conceito buscam uma expressão análoga à música e sofrem agora em si mesmos o poder da música". Ainda assim, para o filósofo alemão, a poesia, uma vez que figura a música por imagens e conceitos, isto é, por meio da linguagem, não pode "alcançar por completo o simbolismo universal da música"; em outras palavras, há um limite entre a poesia e a música que é, segundo Nietzsche, impossível transpor. Mário, por sua vez, em seu pensamento e em sua literatura, não raro procura ultrapassar esse limite que, mesmo nas reflexões de um pensador "dionisíaco" como o autor d'O nascimento da tragédia, era considerado intransponível. Nietzsche, Friedrich. $O$ nascimento da tragédia, São Paulo: Companhia das Letras, 1999, pp. 49-51.
} 
surrealista de signos, no qual a totalidade dos materiais da tradição é mobilizada e organizada de forma original, surpreendente e sem lógica aparente. No transe do cantador, a tradição e o sujeito passam por completo um no outro, resultando dessa possessão recíproca um canto hiper-individual e hiper-coletivo ao mesmo tempo, diferente dos que pertencem ao repertório decorado - nesse sentido, Macunaíma, como notou Gilda de Mello e Souza, é o canto novo por excelência de Mário de Andrade ${ }^{665}$.

Sendo assim, pode-se dizer que a linguagem, no canto novo, se constitui abolindo-se a si mesma. Acede ao estatuto de uma linguagem absoluta, liberada da função referencial, portanto uma linguagem não alienada, em que forma e conteúdo são uma e a mesma coisa, mas ao preço de destruir-se todo significado: o sentido pleno coincide com a completa ausência de sentido. No contexto, portanto, do pensamento marioandradino, o canto novo é a fulguração, a "lucilação sobre-humana" de uma linguagem impossivel, capaz de expressar o Brasil, a paradoxal formação histórica brasileira, mas ao preço de aniquilar-se como linguagem significativa ${ }^{666}$. Por isso, se não deixa de ser um momento de plenitude, o canto novo é também, e principalmente, um canto agônico. Ora, por si mesma, toda improvisação, gênero em que a música opera sempre in extremis, ou seja, no limite de sua própria desaparição, é agônica, assim como a morte, diz Jankélévich, é a improvisação por excelência, uma vez que "o homem está sempre desarmado para a suprema aventura, aquela que ocorre sempre pela primeira e última vez. [...] O homem não tem uma conduta para a morte [...], e tendo em vista que morrer é ao mesmo tempo começar e terminar, começar terminando, terminar começando, morrer é por definição mesmo improvisar"667. Na obra de Mário de Andrade, entretanto, o canto novo não é apenas agônico, mas também sacrificial. No

\footnotetext{
${ }^{665}$ Souza, Gilda de Mello e. O tupi e o alaúde, op. cit., pp. 22-29. A comparação entre o processo de composição de Macunaíma e o do canto dos cantadores é sugerida pelo próprio Mário, em uma carta aberta sobre o livro, na qual o autor responde a um crítico. "A Raimundo Moraes", in Táxi e crônicas no Diário Nacional, op. cit., pp. 344-346.
}

666 " [...] texto inventado e sem nexo, multiplicando versos-feitos sobre sertão, despedidas, bois, amor e trabalhos de engenho, numa lucilação sobre-humana em que todo o Nordeste se expandia com fragor". Andrade, Mário de. "Vida do Cantador (3 Lição)" [1943], in Vida do cantador, op. cit., p. 47.

${ }^{667}$ Jankélévitch, Vladimir. Liszt: rhapsodie et improvisation, Paris: Flammarion, 1998, p. 170-171. 
momento em que tira o canto novo, o rapsodo, diz Mário, encontra-se "divinizado", isto é, possuído pela divindade, como a vítima no instante do sacrifício.

Na última crônica da série "Vida do Cantador", por exemplo, Chico Antônio tira o canto novo para acalmar os bois da fazenda, que choram reunidos, num "lamento insuportável", em torno da poça de sangue de um novilho assassinado ${ }^{668}$. Como se sabe, o sacrifício do boi é uma imagem recorrente na reflexão de Mário de Andrade sobre o Brasil. O animal era tido pelo escritor como "o bicho nacional por excelência", uma espécie de totem da nação ${ }^{669}$, e seu sacrifício simbólico constitui o núcleo daquela que Mário considerava a única dança dramática propriamente nacional, o Bumba-meuBoi ${ }^{670}$. Em Macunaíma, o sacrifício do Boi Bumbá é descrito no final do livro, e antecipa o sacrifício do "herói de nossa gente"671. Pode-se dizer, portanto, que a Paixão do Boi representava, na meditação marioandradina acerca da nacionalidade, o próprio pathos brasileiro672. Assim, o Boi Paciência, espécie de alegoria do povo do Brasil imaginada por Mário, o boi que suporta o sofrimento continuado, figura no poema "Brasão" como uma espécie de alegoria do Brasil e reaparece afogado no rio, como se tivesse sido entregue às piranhas, na "Meditação sobre o Tietê", quando o poeta reflete sobre a má-infinidade nacional. No "Rito do Irmão Pequeno", a imolação dos "bois pesados" é o ato decisivo do processo de negação dos valores europeus e burgueses: "Só isso deixará da gente o mundo tão longínqüo...”, diz o eu-lírico, referindo-se à imolação dos bois. Para Mário de Andrade, portanto, no sacrifício do boi reside algo como o momento de verdade do Brasil. A dor que tem origem nesse sacrifício encontrará sua expressão mais pungente no canto novo de Chico Antônio, na cena final das crônicas de "Vida do cantador": "Foi quando se escutou um grito que subia, um grito sobrehumano, agudíssimo, tão nítido que feria, tão forte que dominou a voz lamentosa dos bois. Chico Antônio trepado no mourão mais alto da porteira grande, aboiava”. A

\footnotetext{
${ }^{668}$ Andrade, Mário de. "Vida do Cantador (Última Lição)" [1943], in Vida do cantador, op. cit., p. 62.

${ }^{669}$ Lopez, Telê Porto Ancona. Mário de Andrade: ramais e caminho, op. cit., pp. 126-136.

${ }^{670}$ Andrade, Mário de. Danças dramáticas do Brasil, Belo Horizonte: Itatiaia, 2002.

${ }^{671}$ Souza, Gilda de Mello e. O tupi e o alaúde, op. cit., p. 18.

${ }^{672}$ Knoll, Victor. Paciente arlequinada, op. cit., pp. 211-217.
} 
tristeza dos animais se concentra e se exprime ao extremo no cântico de Chico Antônio. A música incorpora o sofrimento e o eleva a sua expressão suprema, enquanto o cantador assume ele mesmo o destino do Boi: ao final do canto, ele liberta o rebanho e, ao fazê-lo, é morto por um zebu.

Também no Café encontra-se um canto novo, e também nesse caso ele é um canto sacrificial. Trata-se da "Endeixa da Mãe", produzida quando a personagem, chamada a falar diante dos deputados, alucina, esquece o discurso que decorara, assim como os cantadores no apogeu da inspiração, e profere um canto delirante e original. Ora, conforme visto algumas páginas atrás, a "Endeixa da Mãe" incorpora o canto de Verônica, durante o qual a cantora apresenta ao público a marca de sangue do rosto do Cristo supliciado. O teor sacrificial da "Endeixa", entretanto, não se limita à referência à Paixão de Cristo. De acordo com Mário de Andrade, é o próprio sofrimento histórico das massas populares no Brasil, sofrimento entendido como sacrifício, que canta por meio da Mãe: "Sem resolver, sem decidir, sem consciência, sem nada, apenas movida por um martírio secular que a desgraça transmite aos seus herdeiros, ela se põe a falar. Não são dela as palavras que movem-lhe a boca, são do martírio secular"673. Possuída pelo sacrifício do povo, a Mãe entra em transe e canta. Nesse contexto, o canto novo é a expressão imediata do pathos trágico, o pathos nacional - Café, vale lembrar, é definida por seu autor como uma "tragédia secular"; nela, vimos, a própria "revolução brasileira" é uma revolução trágica ${ }^{674}$.

De certo modo, Paulicéia desvairada constitui-se também como um canto novo, embora Mário de Andrade, à época em que escreveu o livro, ainda não tivesse estudado os processos de criação dos cantadores nordestinos e apenas esboçasse as suas pesquisas folclóricas e a incorporação de modelos da arte popular em sua literatura. No canto novo de Paulicéia, os materiais agenciados pelo turbilhão criativo incluem as formas e as imagens da poesia clássica, alguns elementos da cultura popular e, principalmente, os

\footnotetext{
${ }^{673}$ Andrade, Mário de. Café, in Poesias completas, op. cit., p. 410.

${ }^{674}$ Em carta de 1927 a Alceu Amoroso Lima, Mário afirma que "todo o Clã do Jabuti”, livro que aspira a uma síntese nacional, como vimos, é marcado pelo "sentimento trágico da vida". Idem. 71 cartas de Mário de Andrade, op. cit., p. 21.
} 
espaços diversos da cidade de São Paulo. Quando compôs a obra, Mário conhecia e dominava com virtuosismo, como os "rapsodos" nordestinos, o repertório das formas tradicionais. Em carta de 1935, recorda "o parsaniano que sempre fora, o virtuoso de estilos que ora fazia um soneto camoniano, ora outro a Cláudio Manoel da Costa, e sabia de cor uma quantidade fenomenal de versos de Camões, Bilac, Macedo Papança, Vicente de Carvalho e Gonçalves Dias"675. No "Prefácio Interessantíssimo", apresenta um soneto de sua autoria para mostrar que sabe compor poemas clássicos, e afirma que “podia publicar meus versos metrificados". Publica, porém, uma "poesia nova", de que a tradição também participa - "Não desdenho os baloiços dançarinos de redondilhas e decassílabos" ${ }^{\prime 676}$-, mas de modo fragmentário, combinado aos mais diversos materiais em uma "ordem imprevista". Entre esses materiais variados que atuam no poeta, predominam os elementos da própria cidade arlequinal, que são agenciados de maneira surpreendente, muitas vezes surrealista, pelo poeta em transe.

Como se sabe, assim como o canto novo, os poemas de Paulicéia foram produzidos em um transe de criação, que Mário recorda como um jorro irreprimível de palavras que se organizam sem significado aparente ${ }^{677}$. Da mesma forma que o transe do cantador na obra de Mário, o "estouro" de Paulicéia não deixa de ter conotações sacrificiais, uma vez que a motivação imediata da composição do livro, de acordo com os relatos de Mário, foi uma discussão acalorada que o escritor teve com a família sobre a Cabeça de Cristo, de Brecheret - pois os parentes não aceitavam a representação modernista de Jesus. De certo modo, a defesa do modernismo e a idéia do sacrifício de Cristo se associavam, no momento de criação de Paulicéia desvairada, no imaginário marioandradino. A imagem da crucifixão dos modernistas, sugerida no final das "Enfibraturas do Ipiranga", parece confirmar essa hipótese.

Que a metrópole desvairada produz no observador um estado de espírito semelhante ao transe criativo do cantador nordestino se revela na penúltima crônica de "Vida do Cantador", de 1943. Nesse texto, Chico Antônio, o cantador por excelência,

\footnotetext{
${ }^{675}$ Idem. Ibidem, p. 160.

${ }^{676}$ Idem. "Prefácio Interessantíssimo", in Paulicéia desvairada, in op. cit., p. 66.

${ }^{677}$ Idem. Mário de Andrade escreve cartas a Alceu, Meyer e outros, op. cit., pp. 51-52.
} 
desembarca em São Paulo e a metrópole desvairada lhe provoca um transe semelhante àquele em que se produz o canto novo: "Andava depressa mas com muita dificuldade por causa daquele povaréu maravilhoso como nunca vira. Luzes encarnadas, azuis, verdes, apagavam, acendiam, casas iluminadíssimas, pra quê tanta luz! enfieiras de bondes, moças passeando, misturada formidável. Chico Antônio sorriu. Seu João falava sempre, mas havia também as frases dos outros, se entendia quase tudo, muitas moças passeando, mas que rua incomparável, maior que o Recife! tanta moça linda enfeitada, automóvel que não acabava mais, quedele o prêmio que a morena me mandou, buzinas, uma porta era teatro, músicos, deléns de mais bondes enormes chegando. Chico Antônio estava tonto. Principalmente estava deliciado. Gozava por dentro um chuáá contínuo, enlanguescente, nirvanizante, muito cômodo e conhecido, que era ele. Se repetia um daqueles momentos de paroxismo a que atingia no coco, quando após muito esforço de canto, muito giro de corpo, cachaça operando, desintelectualizado, ai vou montar no carrossel, pra onde vais mulher! todo ele se fundia numa nebulosa eloqüente em que as próprias palavras eram valores imensos cósmicos de música. Era maravilhoso o que estava sentindo" 678 . São Paulo desvaira Chico Antônio, assim como desvaira o poeta de Paulicéia.

No canto novo concebido por Mário de Andrade, a conversão da palavra em música, ou o sacrifício da linguagem, corresponde, no plano da forma, ao sacrifício do cantador, possuído pelo sagrado. $\mathrm{Na}$ obra de Mário, em particular no poema "O trovador", essa conversão sacrificial consiste em uma solução extrema para o beco sem saída do escritor modernista brasileiro, que procura mostrar como somos diferentes da Europa e como, por isso mesmo, devemos exprimir diversamente as coisas ${ }^{679}$ : "Ele não pode deixar de viver pendurado no Ocidente e ele deve tentar não viver pendurado no Ocidente. Ele tem de tentar fazer uma cultura dele, mas a cultura que ele pode fazer é uma cultura pendurada no Ocidente" ${ }^{800}$. Trata-se, em síntese, da famosa "tragédia de

\footnotetext{
${ }^{678}$ Idem. "Vida do Cantador (5ª Lição)" [1943], in Vida do cantador, op. cit., p. 59, grifo meu.

${ }^{679}$ Candido, Antonio. “Literatura e cultura de 1900 a 1945”, in Literatura e sociedade, op. cit., p. 121.

680 Idem, intervenção em debate sobre Paulo Emílio. Apud, Arantes, Paulo Eduardo. Sentimento da dialética na experiência intelectual brasileira, op. cit., p. 16.
} 
Nabuco", expressão com que Drummond se referiu, em carta a Mário de Andrade, a uma importante, inescapável e desesperadora experiência intelectual brasileira, a que o eminente abolicionista deu feição clássica: "Na América falta à paisagem, à vida, ao horizonte, à arquitetura, a tudo o que nos cerca, o fundo histórico, a perspectiva humana; na Europa nos falta a pátria. [...] O sentimento em nós é brasileiro, a imaginação [estética ou histórica, portanto a cultura] é européia" ${ }^{981}$. Mário, por sua vez, conferiu a essa sensação de dualidade, de "despaisamento" do homem culto no Brasil, o nome de "moléstia de Nabuco", uma vez que para o trágico não há saída, ao passo que o mal-estar da cultura brasileira, para Mário, podia ser curado. $\mathrm{O}$ antídoto consistia no "trabalho de abrasileiramento do Brasil", o que implica "sentir e viver a nação" e, sobretudo, "tradicionalizar" a cultura brasileira, ou seja, incorporar em larga escala os elementos dispersos da tradição nacional: "Moléstia-de-Nabuco é isso de vocês andarem sentindo saudade do cais do Sena em plena Quinta da Boa Vista e é isso de você falar dum jeito e escrever covardemente colocando o pronome carolinamichaelismente. Estilize a sua fala, sinta a Quinta da Boa Vista pelo que é e foi e estará curado da moléstia-de-Nabuco. Nós já temos um passado guaçu e bonitão pesando em nossos gestos; o que carece é conquistar a consciência desse peso, sistematizá-lo e tradicionalizá-lo, isto é, referi-lo ao presente" ${ }^{982}$. Em suma, conforme dito, era preciso realizar o processo de formação de nossa cultura, processo que tinha de ser movido pelos homens, uma vez que não era espontâneo entre nós ${ }^{683}$. Para isso, Mário propõe, na expressão de Antonio Candido, o "desrecalque localista”, ou a valorização - "poder-seia até dizer redenção", diz o crítico - do dado local em oposição à norma européia, o aproveitamento das formas sociais e artísticas que se encontravam no país, em especial

\footnotetext{
${ }^{681}$ Nabuco, Joaquim. Minha formação, op. cit., pp. 58-59.

682 Entrevista ao jornal A Noite, "Assim falou o papa do futurismo" [1925]. In Andrade, Mário de. Entrevistas e depoimentos, op. cit., pp. 18-19.

683 É preciso "forçar a nota", diz Mário em carta de 1935. In Mário de Andrade escreve cartas a Alceu, Meyer e outros, op. cit., p. 153.
} 
entre as camadas populares, em detrimento da imitação dos modelos do Velho Mundo 684 .

Mário de Andrade, entretanto, sabia que a tarefa exigia um tour de force: "a tentativa em que me lancei é uma coisa imensa, enorme, nunca foi pra um homem só", escreve em 1925 a Manuel Bandeira ${ }^{685}$. Assumindo essa empreitada monumental como a razão de ser de seu trabalho, Mário decidiu dedicar a totalidade de sua atividade intelectual à formação cultural brasileira: "balanços de época, poemas meditativos, programas de estudo ou instituições culturais bem planejadas, tudo convergia, solicitado por uma 'formação' ainda mal resolvida" ${ }^{686}$. Nesse contexto, o problema da linguagem brasileira, a linguagem que permitiria aos brasileiros "expressarem-se com identidade" ${ }^{987}$, tornou-se uma das preocupações teóricas e práticas mais constantes do escritor. Tratava-se de realizar a "codificação das tendências e constâncias da expressão língüística nacional", de modo a permitir a "estilização culta da linguagem popular da roça como da cidade, do passado como do presente" ${ }^{988}$. Como disse Roberto Schwarz, o autor de Macunaíma pretendia "reunir e abraçar no jeito erudito-informal da prosa o conjunto drasticamente desnivelado das regiões, culturas e classes do país" ${ }^{689}$. No limite, o programa visava, de acordo com o próprio escritor, a "criar uma linguagem culta brasileira" ${ }^{690}$, não obstante Mário afirmasse muitas vezes que não tinha qualquer pretensão de criar "a Língua Brasileira".

\footnotetext{
${ }^{684}$ Candido, Antonio. "Literatura e cultura de 1900 a 1945", in Literatura e sociedade, op. cit., 119-123. Mário costumava advertir que a incorporação das formas populares deveria dar-se sempre no sentido de uma aproveitamento "culto", erudito, das manifestações artísticas do povo. Assim, acerca da necessidade de nacionalizar a música brasileira, ele escreve: "Si de fato agora que é período de formação devemos empregar com freqüência e abuso o elemento direto fornecido pelo folclore, carece que a gente não esqueça que msica artística não é fenômeno popular porém desenvolvimento deste". Andrade, Mário de. Ensaio sobre a música brasileira, op. cit., p. 30.

${ }^{685}$ Andrade, Mário de. Correspondência-Mário de Andrade \& Manuel Bandeira, op. cit., p. 181.

${ }^{686}$ Arantes, Otília Beatriz Fiori; Arantes, Paulo Eduardo. Sentido da formação, op. cit., p. 18.

${ }^{687}$ Andrade, Mário de. "O movimento modernista”, in Aspectos da literatura brasileira, op. cit., p. 268.

${ }^{688}$ Idem. Ibidem, p. 270. Idem. A lição do amigo, op. cit., p. 23.

${ }^{689}$ Schwarz, Roberto. “Outra Capitu”, in Duas meninas, op. cit., p. 140.

${ }^{690}$ Andrade, Mário de. A lição do amigo, op. cit., p. 24.
} 
Iniciado no começo dos anos 1920, o trabalho de abrasileirar a linguagem se consuma em Macunaíma [1928], que procura realizar, no campo lingüístico como em tantos outros, uma síntese totalizadora: "copiei todos, [...] copiei o Brasil”, conclui Mário sobre o livro, notando que a linguagem de sua rapsódia recolhe e mistura fontes das diversas regiões e épocas do Brasil ${ }^{691}$. Manuel Bandeira chegou a sugerir que a obra “esgotava o Brasil literatizável”692. Com efeito, os materiais reunidos vão da Carta de Caminha às vanguardas, e incluem os cronistas do período colonial, lendas nacionais e estrangeiras, os viajantes-naturalistas do século XIX, provérbios e expressões populares, regionalismos, falas de índios, oratória fradesca, fórmulas mágico-religiosas, discurso doutoral, estrangeirismos, prosa poética romântica etc. A impressionante abrangência da incorporação levou parte da crítica a considerar que a própria dimensão da autoria desvanece nesse texto plural, que se constitui por meio da apropriação e do agenciamento de discursos múltiplos ${ }^{693}$. Sob essa perspectiva, a rapsódia de Mário de Andrade aparece como obra coletiva, extra-individual, um "esqueleto de tradições" que a criação individual se limitou a unificar e ornamentar ${ }^{694}$.

Mário, contudo, afirmava no fim da vida que seu programa lingüístico produzira o resultado contrário ao esperado. Sobre Macunaíma, ele comentou: "Quis escrever um livro em todos os linguajares regionais do Brasil. O resultado foi que, como já disseram, me fiz incompreensível até para os brasileiros" ${ }^{995}$. Em outras palavras, concebida como nacional, a linguagem da rapsódia era reconhecida por seu próprio autor, por fim, como uma linguagem ultra-individual. Já à época da publicação do romance, como vimos, o escritor notava um paradoxo semelhante em suas poesias: "Eis a miséria: é que os poemas, estes, muito menos individualistas na forma e no pensamento geral, atingiram o máximo de individualismo, já não podem mais interessar ninguém senão eu"696. O

\footnotetext{
${ }^{691}$ Idem. “A Raimundo Moraes”, in Táxi e crônicas no Diário Nacional, op. cit., p. 345.

${ }^{692}$ Idem. Correspondência - Mário de Andrade \& Manuel Bandeira, op. cit., p. 404.

${ }^{693}$ Souza, Eneida Maria de. A pedra mágica do discurso, Belo Horizonte: Editora UFMG, 1999.

${ }^{694}$ Campos, Haroldo. Morfologia do Macunaíma, São Paulo: Perspectiva, 2008.

695 Em entrevista de 1944. Andrade, Mário de. Entrevistas e depoimentos, op. cit., p. 105.

${ }^{696}$ Idem. Correspondência - Mário de Andrade \& Manuel Bandeira, op. cit., p. 377.
} 
caráter pessoal de Macunaíma e da "linguagem brasileira" elaborada por Mário de Andrade não escapou a alguns críticos. Gilda de Mello e Souza, em seu estudo clássico, ressaltou a marca individual da rapsódia ${ }^{697}$, e Roberto Schwarz afirmou a respeito da linguagem marioandradina: "Nada mais pessoal e intransferível que a fisionomia dessa escrita que se queria funcional, como que indicando que seu gigantismo não era repetível. Com efeito, hoje ela se lê como uma extraordinária façanha de expressão individual, associada ao desejo de aperfeiçoar a nacionalidade" ${ }^{998}$.

Nesse ponto, vale recuperar, ainda que de forma breve, a boa lição de Adorno, segundo a qual "a linguagem estabelece a mediação entre lírica e sociedade no que há de mais intrínseco. [...] O instante do auto-esquecimento, no qual o sujeito submerge na linguagem, não consiste no sacrifício do sujeito ao Ser. Não é um instante de violência, nem sequer de violência contra o sujeito, mas um instante de reconciliação"699. Pode-se dizer, portanto, que o programa lingüístico de Mário parte da tomada de consciência de que, no Brasil, essa mediação entre o indivíduo e a sociedade falta ao poeta; ele tem por base o desejo de elaborar essa instância mediadora, o que significa dar sentido à poesia lírica e, no limite, torná-la possível. Mário, entretanto, em grande medida em função das próprias condições históricas que o levaram a buscar, a todo custo, uma linguagem que instaurasse uma mediação autêntica entre a sua subjetividade e o Brasil, concebe e realiza esse busca sob a forma do sacrifício de si mesmo. Sendo assim, conforme dito, a linguagem construída por Mário tem por um lado um caráter hipercoletivo, visto que, nela, o sujeito se aniquila, e de tal maneira que ela incorpora, ou pretende incorporar, a totalidade do material lingüístico nacional; por outro lado, uma vez que seu fundamento tem de ser sacrificial, essa linguagem é altamente artificial, portanto ela possui também um caráter hiperindividualizado, o que é próprio da literatura, mas não da formação das línguas nacionais. Nesse sentido, não se deve ver nessa coincidência do individual e do coletivo uma síntese autêntica, ao contrário. Elevados à sua potência máxima em função do esquema sacrificial, indivíduo e sociedade suprimem-se mutuamente nessa língua, de

\footnotetext{
${ }^{697}$ Souza, Gilda de Mello e. O tupi e o alaúde, op. cit.

698 Schwarz, Roberto. “Outra Capitu”, in Duas meninas, op. cit., p. 142.

${ }^{699}$ Adorno, Theodor W. "Palestra sobre lírica e sociedade”, in Notas deliteratura I, op. cit., p. 74.
} 
modo que esta, ao mesmo tempo em que pessoalísssima e coletivíssima, não é pessoal nem coletiva.

A matéria histórica resistia às soluções literárias de Mário, pautadas pelos ideal da cultura nacional orgânica. Mais precisamente, a má formação brasileira frustrava o programa lingüístico do escritor e invertia o significado da "mestiçagem lingüística" promovida em Macunaíma. Se há um fracasso na "obra-prima ratada" que, segundo o escritor, é Macunaíma, ele é o fracasso da história na obra de arte, como disse Adorno sobre a Missa Solemnis, a "obra-prima alienada" de Beethoven ${ }^{700}$. Daí o aparente paradoxo de consumar-se na abstração uma de nossas obras mais profunda e amplamente arraigadas na matéria nacional: ao levar a cabo a exigência histórica de uma síntese que a história todavia não permitia realizar, o romance se afasta da realidade e realiza um salto metafísico - não por acaso, Macunaíma termina, segundo o próprio Mário, com a imagem da "contemplação extática da Divindade"701. Isso posto, voltando ao problema da linguagem, assim como a "desgeograficação" da fauna, da flora, dos mitos, dos costumes etc. produz uma imagem abstrata, embora coalhada de "concretos", da realidade brasileira, a linguagem macunaímica, em que sedimentam as linguagens de "todas" as classes, regiões e tempos do Brasil, tende a resolver-se na abstração musical.

A resistência que a má formação nacional impunha ao programa de síntese lingüística elaborado por Mário nos anos 1920 encontra-se no núcleo do último poema do Clã do Jabuti, obra irmã de Macunaíma, uma vez que foi publicada poucos meses antes da rapsódia e, como esta última, também é movida pelo desejo de plasmar a linguagem brasileira. No acalanto que encerra o livro, o segundo dos "Dois poemas acreanos", o eu-lírico paulistano desespera-se ao querer cantar para fazer dormir um seringueiro amazônico que lhe surge na memória. Apesar dos esforços, ele não acha a “palavra brasileira”, capaz de adormecer o irmão desconhecido:

\footnotetext{
700 À medida que incorpora esse fracasso por meio da sátira que permeia toda a prosa e da negatividade das páginas finais, Macunaíma ameaça submeter distância as contradições brasileiras que todavia não chega a superar. Para a idéia de Adorno mencionada, ver "The alienated Magnus Opus: On the Missa Solemnis", Beethoven: The Philosophy of Music, op cit., pp. 141-153.

${ }^{701}$ Andrade, Mário de. Mário de Andrade escreve cartas a Alceu, Meyer e outros, op. cit., p. 15.
} 
"Seringueiro brasileiro,

$\mathrm{Na}$ escureza da floresta,

Seringueiro, dorme.

Ponteando o amor eu forcejo

Pra cantar uma cantiga

Que faça você dormir.

Que dificuldade enorme!

Quero cantar e não posso,

Quero sentir e não sinto

A palavra brasileira

Que faça você dormir...

Seringueiro, dorme..."

Acalanto paradoxal, cujo tema é a própria impossibilidade de acalantar. As palavras discorrem sobre a ausência de qualquer experiência compartilhada entre o eulírico e o seringueiro, ao passo que é essencial aos acalantos o cunho da tradição comum, tendo em vista que sua eficácia depende da mobilização de temas pertencentes à cultura tradicional, que permitem a construção de um universo mítico, em que o acalentado se projeta e reconforta ${ }^{702}$., Nos "Dois poemas acreanos", assim como a morte em relação à vida e o sagrado em relação ao profano, o seringueiro do Acre aparece ao poeta modernista de São Paulo como o estranho ${ }^{703}$, ou melhor, como o outro absoluto, outro de todo, com quem nenhuma comunicação pode ser concebida. Somente quando o significado das palavras perde importância e a musicalidade, sob a forma do puro vaivém do ritmo pendular da berceuse, assume o primeiro plano da composição,

\footnotetext{
${ }^{702}$ Fernandes, Florestan. "Contribuição para o estudo sociológico das cantigas de ninar", in Folclore e mudança social na cidade de São Paulo, São Paulo: Martins Fontes, 2004, p. 321-341.

703 Alguns aspectos da aparição do seringueiro aproximam-no do Unheimlich freudiano: a aparição é fantasmagórica e perturbadora, produz o horror terrífico da alteridade radical, surge das sombras, como algo que se encontrava oculto e que vem subitamente à tona no pensamento do eu-lírico, figura como a imagem de uma vida "primitiva" que a razão, representada pela erudição do escritor, deixou para trás, e representa àquilo que pertence e não pertence à mesma pátria. Freud, Sigmund. "L'inquiétante étrangenté", in L'inquiétante étrangenté et autres essais, Paris: Gallimard, 2003, pp. 211-263.
} 
uma relação se estabelece entre os dois desconhecidos, que se tornam brasileiros enfim, e o eu-lírico alcança embalar o sono do seringueiro. No limite, trata-se de constranger os opostos a se identificarem por meio da virtude da música:

"Porém eu sou seu amigo

E quero ver si consigo

Não passar na sua vida

Numa indiferença enorme.

Meu desejo e pensamento

(...numa indiferença enorme...)

Ronda sob as seringueiras

(...numa indiferença enorme...)

Num amor-de-amigo enorme...

Seringueiro, dorme!

Num amor-de-amigo enorme

Brasileiro, dorme!

Brasileiro, dorme.

Num amor-de-amigo enorme

Brasileiro, dorme.

Brasileiro, dorme,

Brasileiro... dorme...

Brasileiro... dorme..."

Dada a ausência de toda mediação possível entre o eu-lírico e o seringueiro - em especial, dada a ausência da mediação por excelência, a língua -, e uma vez que o eulírico insiste em confraternizar os dois desconhecidos ("Porém eu sou seu amigo/ E 
quero ver si consigo/ Não passar na sua vida/ Numa indiferença enorme.”), o poema recorre a mediações que tendem a abolir a distância entre o mesmo e o outro, ou seja, a mediações que se põem, conforme o conceito de José Antonio Pasta Júnior examinado anteriormente, como imediatidade: a magia, o amor e, sobretudo, a música.

A magia, que nasce da onipotência do pensamento ${ }^{704}$ e tem em seu núcleo a idéia da eficácia imediata do desejo ${ }^{705}$, “age à distância e no entanto por conexão direta, quando não por contato, móvel e movente sem mover-se, impessoal e assumindo formas pessoais, divisível e contínua"706; nela, "o elemento da distância é desprezado; em outras palavras, a telepatia é admitida como certa"707: "Meu desejo e pensamento/ Ronda sob as seringueiras/ Num amor-de-amigo enorme...". No "Acalanto", a enunciação mesma das palavras transporta o espírito do eu-lírico de São Paulo para floresta amazônica e realiza, de modo sobrenatural, o desejado processo de aproximação com o seringueiro. Nesse sentido, a distância suprimida pelos versos mágicos não se restringe à distância continental que separa São Paulo do Amazonas. Uma vez que seu princípio é a onipotência do pensamento, a magia tende a suprimir a distância entre as palavras e as coisas, entre o signo e o objeto - ela tende a forçar a barreira simbólica: "A linguagem mágica, sob suas formas mais específica, escapa não somente ao conceito, mas também ao sistema mesmo da língua, deformando as palavras ao ponto de as tornar irreconhecíveis. [...] O paradoxo do 'símbolo' mágico é o de escapar parcialmente ao simbólico, de ser utilizado como um instrumento destinado a provocar uma espécie de curto-circuito entre o desejo e o real"708. À vista disso, e considerandose que na música, justamente, a distinção entre significante e significado tende a desaparecer, a linguagem mágica tende a assumir a forma de uma "música das letras"709.

\footnotetext{
${ }^{704}$ Freud, Sigmund. Totem et tabou, in Oeuvres complètes, XI, Paris: PUF, 1998, pp. 283-310.

${ }^{705}$ Bastide, Roger. Éléments de sociologie religieuse, Paris: Stock, 1997, pp. 20-23.

${ }^{706}$ Mauss, Marcel. "Esboço de uma teoria geral da magia”, in op. cit., p. 151.

${ }^{707}$ Freud, Sigmund. Op. cit.

708 Vadé, Yves. L'enchantement littéraire: écriture et magie de Chateaubriand à Rimbaud, op. cit., p. 16.

${ }^{709}$ Kristeva, Julia. La Révolution du langage poétique, Paris: Seuil, 1974, p. 62.
} 
Como se verá, a música, mais que a palavra, conduz no "Acalanto" de Mário a transmigração da alma do eu-lírico e sua comunhão com o seringueiro desconhecido.

O sentimento que está na raiz dessa operação mágica é o "amor-de-amigo"710. Amor-de-amigo, e mesmo o amor em geral, para Mário de Andrade, é essencialmente ser o outro, isto é, suprimir toda distância que separa o mesmo do outro. Em carta a Drummond, o autor de Amar, verbo intransitivo caracteriza nos seguintes termos o modo de amar do poeta itabirano, distinguindo-o tacitamente do seu: "Você ama e com que amor ansiado! Solidariza, participa, digamos que se entregue. Mas você não se integra, não se dissolve em. Você não se transpõe. Se transporta, mas permanece um insolúvel'"711. Nesse sentido, não é raro encontrarmos na correspondência de Mário com seus amigos expressões como "você eu vivo demais", "eu viverei você", "você afinal sou eu mesmo", "vivi o seu dia feliz"712. Nas Poesias, por sua vez, a realização do amor sexual costuma ser representada como a consumação de uma identificação com o outro, a qual é invariavelmente apresentada como uma identificação mortal ${ }^{713}$. Ao final, por exemplo, do "Girassol da madrugada", o último dos grandes poemas de amor de Mário, o "olhar estagnado" da amada é a "lagoa" em que o eu-lírico, como "Narciso", dizem os versos, contempla sua própria imagem refletida ${ }^{714}$. Assim como a Medusa, a mulher tem “a morte nos olhos": neles, o eu-lírico vê a si mesmo no outro, mas a um si mesmo que é outro, isto é, o duplo de si mesmo, o morto de si mesmo, o mesmo no além ${ }^{715}$. O objeto amado, na lírica marioandradina, é o estranho, o Outro que é o mesmo invertido. No "Acalanto do seringueiro", é a própria formação do país que se almeja alcançar por

\footnotetext{
710 “A magia tem sua raiz no sentimento”. Bastide, Roger. Op. cit., p. 20.

${ }^{711}$ Andrade, Mário de. A lição do amigo, op. cit., p. 240.

712 Idem. Ibidem, pp. 38, 239; Idem. Correspondência - Mário de Andrade \& Manuel Bandeira, op. cit., pp. 286, 290.
}

713 Em Mário, não há grande distinção entre amor-de-amigo e amor sexual, uma vez que ambos são regidos por uma estrutura semelhante, a da supressão da alteridade. Essa indistinção está no centro dos "Poemas da amiga".

714 Na simbologia marioandradina, a lagoa é um lugar de morte, seja esta violenta ou pacífica. No "Grifo da morte", poema de 1933, o "instante do lago" é o momento da "benfeitora morte", que pacifica a alma do eu-lírico. Em Macunaíma, a lagoa é o lugar onde reside a irresistível e mortal Uiara, que estraçalha o herói. Andrade, Mário de. Poesias completas, op. cit., p. 348.

715 Vernant, Jean-Pierre. La mort dans les yeux: figure de l'Autre en Grèce ancienne, Paris: Hachette, 1998, pp. 75-82. 
meio desse amor - ideal de que Aristóteles apontou a contradição: "E Sócrates é enfático ao louvar a unidade do Estado, o qual, como ele afirma expressamente, é um dos produtos do sentimento e da amizade./ Porém essa unidade seria como a dos amantes do Symposium, os quais, como diz Aristófanes, desejam desenvolver sua afeição até se tornar um só ser em vez de dois, caso em que um ou outro, ou ambos, deve perecer" $" 716$.

Nesse ponto, deparamos problemas que foram examinados a fundo por José Antonio Pasta Júnior em seus trabalhos sobre literatura brasileira. Uma síntese de algumas idéias centrais desenvolvidas pelo crítico nos permitirá compreender melhor não somente a forma do amor marioandradino, mas também a base histórico-social em que essa forma se radica. Como vimos na primeira parte deste trabalho, Dd acordo com Pasta, a conjunção contraditória de capitalismo e escravidão, que modelou de maneira decisiva a sociedade brasileira desde a constituição do país e que nunca foi inteiramente superada, produz a vigência simultânea de dois regimes opostos de relação interpessoal: "Por um lado, um regime antes de tudo moderno que corresponde, grosso modo, às relações capitalistas de produção, que prescreve a separação ou a diferença entre o mesmo e o outro; e, por outro lado, um regime que não reconhece a diferença entre o mesmo e o outro, no qual essa diferença é mesmo rigorosamente inconcebível, isto é, um regime que, por sua vez, corresponde aos laços do patriarcalismo escravista" 717. Sendo assim, afirma o crítico, e uma vez que essa combinação contraditória não foi superada pela Independência nem pela Abolição, perpetuando-se ao longo da República Velha e além, "a contradição e as infinitas complicações que derivam do fato de que a alteridade - ou a autonomia - do outro seja ao mesmo tempo reconhecida e negada, pressuposta e inconcebível, constituem em profundidade o imaginário paradoxal das relações interpessoais e intersubjetivas no Brasil"718.

\footnotetext{
716 Aristóteles. "Política”, in Os Pensadores - Aristóteles, São Paulo: Nova Cultural, 2000, p. 174.

717 Pasta Júnior, José Antonio. "Volubilidade e idéia fixa (o outro no romance brasileiro)", in Sinal de menos, nº4, São Paulo: 2010, p. 18.

718 Idem. "O romance de Rosa - temas do Grande Sertão e do Brasil”, in op. cit., p. 67.
} 
Isso posto, pergunta Pasta: “como estabelecer uma relação com o outro onde a alteridade é negada e afirmada ao mesmo tempo?"; "[como pode] a subjetividade obedecer à exigência de que ela seja distinta do outro, e, ao mesmo tempo, indistinta do outro?"719. A rigor, diz o crítico, “só há um modo de fazê-lo: 'afirmar' que o outro é o mesmo - o que a um tempo preserva a referida distinção e a abole"720. O outro é o mesmo ou, simplesmente invertendo, o mesmo é o outro, eis a resposta, conclui Pasta, que as personagens mais representativas da literatura brasileira dão à "esfinge brasileira: elas são elas mesmas sendo igualmente o outro que lhes faz face, de modo que se pode dizer que elas se formam passando no seu outro: elas vêm a ser tornando-se o outro" isto é, suprimindo o outro ${ }^{721}$. Ao mesmo tempo, se o mesmo vem a ser sendo o outro, "ele vem a ser no e pelo movimento mesmo em que deixa de ser: ele se forma suprimindo-se"722 A identificação do mesmo e do outro de que se trata aqui, portanto, não produz a plenitude, mas a supressão recíproca: “cada passagem do mesmo no outro é, por assim dizer, mediada apenas pela destruição, pois se o mesmo suprime o outro apossando-se dele, por seu turno este o aniquila, ocupando-lhe o lugar" 723 . Esta é a lógica de o que Pasta definiu como a da formação supressiva, em que o leitor terá percebido também a dinâmica da luta de morte, exposta anteriormente, e que só pode terminar, de acordo com o crítico, por meio da aniquilação recíproca dos contendores, isto é, por um duplo e simultâneo gesto sacrificial. A luta de morte, pode-se dizer, é um momento da formação supressiva. Seu regime, demonstra Pasta, profundamente ancorado na matéria histórica brasileira, encontra-se no núcleo das obras capitais de nossas letras.

Quando o amor marioandradino se consuma, o mesmo é o outro e o outro é o mesmo. A vigência desse regime se observa não apenas nas cartas e na poesia, mas também em Macunaíma. Nos amores do herói com $\mathrm{Ci}$, a identidade sexual das

\footnotetext{
${ }^{719}$ Idem. "Volubilidade e idéia fixa (o outro no romance brasileiro)", in op. cit., p. 18.

${ }^{720}$ Idem. "O romance de Rosa - temas do Grande Sertão e do Brasil”, in op. cit., p. 64.

${ }^{721} \mathrm{Idem}$. "Volubilidade e idéia fixa (o outro no romance brasileiro)", in op. cit., p. 19.

${ }^{722}$ Idem. "O romance de Rosa - temas do Grande Sertão e do Brasil”, in op. cit., p. 64.

${ }^{723}$ Idem. Ibidem, p. 65.
} 
personagens, conforme observa Pasta, é trocada ${ }^{724}$. As brincadeiras eróticas de Macunaíma com Sofará, por sua vez, assumem variadas formas sadomasoquistas - ora, no sadomasoquismo, a dor dá prazer e o prazer dói, o carrasco é a vítima e a vítima, o carrasco, a submissão é a dominação e a dominação, a submissão ${ }^{725}$ : "Depois das festinhas de cotucar, fizeram a das cócegas, depois se enterraram na areia, depois se queimaram com fogo de palha, isso foram muitas festinhas. Macunaíma pegou num tronco de copaíba e se escondeu por detrás, da piranheira. Quando Sofará veio correndo, ele deu com o pau na cabeça dela. Fez uma brecha que a moça caiu torcendo de riso aos pés dele. Puxou-o por uma perna. Macunaíma gemia de gosto se agarrando no tronco gigante. Então a moça abocanhou o dedão do pé dele e engoliu. [...] Macunaíma principiou atirando pedras nela e quando feria, Sofará gritava de excitação tatuando o corpo dele em baixo com o sangue espirrado. Afinal uma pedra lascou o canto da boca da moça e moeu três dentes. Ela pulou do galho e juque! tombou sentada na barriga do herói que a envolveu com o corpo todo, uivando de prazer. E brincaram mais outra vez"726. A liberdade e a "inocência" com que os amantes se entregam ao jogo sadomasoquista, configurando a imagem de uma sexualidade desrecalcada - ou, como disse Antonio Candido acerca das Memórias de um sargento de milícias, de um "mundo sem culpa"727 - não anula o caráter violento dessas relações. A relação amorosa, nos momentos mais fortes da obra de Mário, realiza-se segundo os regimes da luta de morte e da formação supressiva - nesse sentido, a consumação do amor é também um rito sacrificial em que perecem o sacrificante e o sacrificado.

Nos cinco poemas de "Grã Cão do Outubro", a representação da relação erótica como luta de morte salta aos olhos. À amada, que tem uma "boca hitlerista", insta o

\footnotetext{
724 "Macunaíma desposa Ci, a "Mãe do Mato" - mulher guerreira, espécie de amazona. Enquanto ela parte para a guerra - sempre, aliás -, ele fica em casa, onde adormece molemente, ou cuida do bebê que, apesar de tudo, eles tiveram. Quando ela retorna, lança-o sobre a rede e o possui com furor, diversas vezes, embora ele queira parar no meio". Idem. "Volubilidade e idéia fixa (o outro no romance brasileiro)", in op. cit., p. 21.
}

725 Reik, Theodor. Le masochisme, op. cit. A tendência brasileira para o sadomasoquismo, e seu vínculo originário com a organização patriarcal e escravista da sociedade colonial, foi assinalada por Gilberto Freyre em Casa-grande \& senzala, Rio de Janeiro: Record, 1989, pp. 48-52

${ }^{726}$ Andrade, Mário de. Macunaíma, o herói sem nenhum caráter, op. cit., pp. 12-13
${ }^{727}$ Candido, Antonio. “Dialética da malandragem”, in O discurso e a cidade, op. cit., pp. 40-46. 
poeta: "Me beija! me sufoca em teus braços!/ Que eu só quero ser vencido logo/ Para te perfurar com a cadência do dia e da noite/ E sermos anulados numa paz sem colisão...”. No "Poema tridente", a luta sexual se torna ainda mais violenta: "Ôh besta fera maldita,/ [...] Eu te amo de um amor educado no inferno! Te mordo no peito até o sangue escorrer/ [...] Nos debatemos, o braço esfomeado braceja,/ Golpeia aqui, matou centenas de operários/ [...] Nos odiando no mesmo abraço confundidos/ [...] E agora nem de perdão carecemos/ No mesmo abraço desaparecidos". De certo modo, o amor marioandradino, em que predomina a experiência do gozo, é sempre um liebestod, uma morte de amor, uma morte de amor por excesso de vida, um excesso de vida amorosa que só pode ser morte ${ }^{728}$ : "Boiando nas enxurradas/ Nosso corpo de amor.../ Que beijos, que beijos que eu dou!// Vamos enrolados pelas enxurradas/ Em que boiam corpos, em que boiam os mortos/ [...] Nós vamos com as enxurradas,/ Com a perfeita inocência dos fenômenos da terra,/ Voluptuosamente mortos"729.

Evidente em "Grã Cão do Outubro", a figura da luta de morte também se encontra, embora oculta, nos poemas em que o amor se consuma de maneira "suavíssima". Assim, a despeito da delicadeza que parece presidir o erotismo dos "Poemas da Negra", diz o eu-lírico a certa altura: “Tu me adivinhas, meu amor,/ Porém não queres ser escrava!// Flores!/ Apaixonadamente meus braços desgalham-se,/ Flores!/ Flores amarelas do pau-darco secular!/ [...] Te cobrirei de flores amarelas!// Apaixonadamente/ Eu me defenderei!". Na luta sexual, o amante se constitui passando no seu outro, portanto ele se constitui abolindo-se: "Eu me inundo de vossas riquezas!/ Não sou mais eu!". O amor, desse modo, é uma passagem para a morte: "Não sei si estou vivo.... Estou morto"730. Em outras palavras, mesmo quando sublime, a realização amorosa implica, na lírica de Mário, a supressão da alteridade - "Não sei por que

\footnotetext{
728 Žižek, Slavoj. La Seconde mort de l'Opéra, Paris: Circé, 2006, pp. 7-35.

${ }^{729}$ Andrade, Mário de. "Os gatos”, in Poesias completas, op. cit., p. 314.

730 Vale notar que, segundo Gilda de Mello e Souza e Antonio Candido, a morte também "entra a cada passo, como mediação e limite", na lírica amorosa de Manuel Bandeira, tão diferente, quanto ao mais, da poesia de Mário. Souza, Gilda de Mello e/ Candido, Antonio. "Introdução", in Bandeira, Manuel. Estrela da vida inteira, Rio de Janeiro: Nova Fronteira, 1993, pp. 3-4. As relações entre amor, morte e música em um poema de Bandeira foram examinadas por Davi Arrigucci Jr. em Humildade, paixão e morte: a poesia de Manuel Bandeira, São Paulo: Companhia das Letras, 1999, pp. 165-198.
} 
espírito antigo/ Ficamos assim impossíveis..." - por meio de uma operação identificatória ruinosa, negativa e, em última instância, sacrificial. Na lírica de Mário, a relação erótica é o exercício ritual de uma paixão ${ }^{731}$, um ato "soleníssimo", como diz um verso do "Girassol da madrugada", dramatizado em linguagem soleníssima, por meio do qual se realiza um traspasse conjunto.

No "Girassol da madrugada", o eu-lírico espera escapar ao regime da luta de morte, que impera nos poemas anteriores, de "Grã Cão do Outubro": "Diga ao menos que nem você quer mais desses gestos traiçoeiros/ Em que o amor se compõe feito uma luta;/ Isso trará mais paz, porquanto o caminho foi longo,/ Abrindo o nosso passo através dos espelhos maduros" ${ }^{\prime 732}$. Paralisa-se a luta, e os contendores, em estado de espelho, se refletem: "Nosso par aguarda, soleníssimo,/ Radiando luz, nesse esplendor dos que não sabem mais pra onde ir/ [...] Não há senão Narciso entre nós dois, lagoa/ Já se perdeu saciado o desperdício das uiaras". O movimento pendular de supressão recíproca dos amantes é detido, o "um ou outro" da luta de morte paralisa-se no "um é outro" do espelho ${ }^{733}$. Todavia, de acordo com Pasta, "se o mesmo é o outro, o ser é o não-ser"734. Paralisada, portanto, a báscula da luta de morte entre o mesmo e o outro, inicia-se a báscula entre o ser e o não-ser, de modo que a dinâmica ruinosa da luta de morte se repõe, uma vez que a passagem do mesmo no outro, própria da luta de morte, é também, como vimos, uma passagem do ser no não-ser - se o mesmo vem a ser passando no outro, ele vem a ser deixando de ser.

Com efeito, presos no estado de espelho, os amantes, "que não sabem mais pra onde ir", volatilizam-se, passam para o não-ser: "Ôh que pureza sem impaciência nos calma/ Numa fragrância imaterial, enquanto os dois corpos se agradam/ Impossíveis que nem a morte”. Como notou Lafetá, permeado por um espírito religioso, o poema coloca

\footnotetext{
731 Sobre o amour-passion e a combinação de misticismo e violência nele implicada, ver Rougemont, Denis de. L'amour et l'Occident, Paris: Plon, 2006. Ver também Barthes, Roland. Fragmentos de um discurso amoroso, São Paulo: Martins Fontes, 2003, pp. 3-8.

732 Todas as citações do poema feitas a seguir encontram-se em Andrade, Mário de. "Girassol da madrugada" [1931], in Poesias completas, op. cit., pp. 339-341

${ }^{733}$ Ver Pasta Jr., José Antonio. Pompéia: a metafísica ruinosa d’O Ateneu, op. cit., p. 186.

${ }^{734}$ Idem. “O romance de Rosa - temas do Grande Sertão e do Brasil”, in op. cit., p. 64.
} 
em prática uma espécie de método de desvanecimento - como os métodos de ascese mística, diríamos nós - por meio do qual, passo a passo, os corpos se desmaterializam: “O vosso corpo está delindo no ar/ [...] os teus lábios/ são crianças que se esvaecem”. Por sua vez, a musicalidade riquíssima da linguagem, que se organiza principalmente sob a forma de uma magistral "orquestração de fonemas", "dissolve o sentido lógico [das palavras], ampliando e insinuando conotações múltiplas"735. A música realiza na linguagem, portanto, a mesma evanescência que sofrem as imagens do poema.

Todavia, ao mesmo tempo em que tudo se volatiliza no "Girassol da madrugada", em nenhum momento essa desmaterialização se completa, o que afinal resolveria, ainda que de forma negativa, as contradições que estão na base do poema. Ao contrário, combinado ao movimento ascensional de evanescência, configura-se a cada passo, nos versos do "Girassol", um movimento inverso de descida. Ao mesmo tempo em que multiplica as imagens de leveza e descorporificação, o poema contém imagens de pesadume e mergulho na matéria: "Por que a Divindade muito naturalmente virá./ Agressiva Ela virá sentar em nosso teto,/ E seus monstruosos pés pesarão sobre nossas cabeças,/ De-noite, sobre nossas cabeças inutilizadas pelo amor"; “Agora pouso, agora vou beber vosso olhar estagnado, ôh minha lagoa!’. Na mesma linha, o esplendor e a transparência desdobram-se na escuridão e na opacidade, ao mesmo tempo em que delas são também o desdobramento: "Você apenas esconde os olhos no meu braço e encontra a paz na escuridão./ A noite se esvai lá fora serena sobre os telhados,/ Enquanto o nosso par aguarda, soleníssimo,/ Radiando luz, nesse esplendor dos que não sabem mais pra onde ir"; "Vem chegando a manhã. Porém, mais compacta que a morte,/ Para nós é a sonolenta noite que nasce detrás das carícias esparsas”. Assim, pode-se dizer com Pasta, que identificou um movimento semelhante n'O Ateneu: no "Girassol da madrugada", "tudo que é sólido se quer volatilizar e tudo que é etéreo se quer precipitar em cristalização firme e palpável"736.

\footnotetext{
${ }^{735}$ Lafetá, João Luiz. Figuração da intimidade, op. cit., pp. 161-196.

736 Pasta Jr., José Antonio. Pompéia: a metafísica ruinosa d'O Ateneu, op. cit., p. 254. O estudo da conversão recíproca de evanescência e cristalização encontra-se nas pp. 240-255.
} 
Esse movimento se concentra na imagem paradoxal do êxtase inverso, que não sobe aos céus, mas que desce à terra, cuja descrição também se encontra, como vimos, nos diários de viagem d'O turista aprendiz. Diz o eu-lírico: “Há só meu êxtase pousando devagar sobre você". Há decerto uma atmosfera de misticismo no "Girassol da madrugada", assim como nos "Poemas da negra". O "delírio de união", a "alegria calma", a evanescência metodizada, entre outras coisas, remetem às experiências místicas autênticas ${ }^{737}$. O êxtase, entretanto, o do misticismo, é por definição um movimento ascensional, por meio do qual a alma se libera do corpo e ascende à divindade. No poema de Mário, ao contrário, a alma sai do eu-lírico e desce ao corpo da amada.

Em síntese, no "Girassol da madrugada", o vôo e a prostração, o espírito e a matéria, alternam e convertem-se um no outro, como duas formas de morrer que, combinadas, impedem que se consuma a morte definitiva, uma vez que a evanescência e a materialização, no instante em que se perfazem, convertem-se em seu contrário, desenhando-se desse modo um movimento interminável de trânsito da imanência para a transcendência, e vice-versa. Nesse sentido, o poema figura não a morte que pacifica, mas um morrer que não acaba de morrer, uma agonia perpétua, em que se eterniza a passagem ruinosa para o não-ser. "Eu amo a morte que acaba tudo", escreveu Mário a Bandeira $^{738}$. Sua lírica, entretanto, não cessa de repor a imagem da morte que não termina de acabar. Assim, o poema seguinte ao "Girassol”, "O grifo da morte", que se inicia sob o signo da melancolia e da oscilação infindável entre o mesmo e o outro "Salta o bicho roxo./ Depois ficou ruim,/ Depois ficou roxo,/ Depois ficou ruim,/ Depois ficou roxo,/ Ruim-roxo, ruim-roxo" -, procura levar a cabo a passagem

\footnotetext{
${ }^{737}$ Bastide, Roger. Les problèmes de la vie mystique, op. cit..

${ }^{738}$ Andrade, Mário de. Correspondência-Mário de Andrade \& Manuel Bandeira, op. cit., p. 182.
} 
ritualística para o não-ser ${ }^{739}$ : "Êi-vem a morte/ - ruim-roxo... -/ Consoladora.../ [...] A alma sem tristeza/ Pouco a pouco vai/ Desabrochando/ O instante do lago.// Morte, benfeitora morte,/ Eu vos proclamo/ Benfeitora, ôh morte!/ Benfeitora morte!/ Morte, morte...". Todavia, em seguida, em uma imagem em que não apenas se combinam, mas coincidem, a evanescência e a sedimentação, isto é, o mesmo e o outro, o poema se encerra em uma passagem lentíssima para a morte, morte no gerúndio: "Se escuta no fundo/ A sombra das águas, / - calma serenata... - Se depositando/ Para nunca mais". É como se o poema não pudesse terminar, estendendo ao infinito o processo de extinção contínua do ser e da vida, fixando a imagem de uma infinidade ruinosa.

Nesse limbo entre o ser e o não-ser instala-se o "Rito do irmão pequeno", poema escrito em 1931, no qual o eu-lírico, através de uma série de estações e passagens, chega ao "êxtase parado", ao exercício da "preguiça organizada", "semi-morte igualitária", em que o ser é o não-ser ${ }^{740}$. A essa figura literária subjaz nada menos que a estrutura da formação histórica brasileira, composta sobretudo pelas passagens simultâneas do moderno no arcaico e do arcaico no moderno, movimento que não conhece autêntica superação e que se reatualizava por meio da Revolução de 1930. Uma vez que é, essencialmente, a passagem das formas socioeconômicas burguesas nas formas socioeconômicas pré-burguesas, pode-se dizer que a modernização conservadora, ritmo fundamental de nossa história, tem em seu núcleo mesmo a passagem ruinosa do mesmo no outro, e deste naquele. Dizendo de outro modo, a modernização conservadora consiste ela própria em um vir a ser por meio do não-ser. De sua parte, a lírica de Mário apresenta as passagens do mesmo no outro, do sujeito no

\footnotetext{
739 Vale notar que a "grave melancolia" relaciona-se ao momento histórico em que foi escrito o poema, em 1933. Após mencionar o bicho "ruim-roxo, ruim-roxo", que "salta" representando perigo e ameaça, o eu-lírico exclama: "Milhões de bandeiras!// Os camisas pretas,/ Os camisas pardas,/ Os camisas roxas,/ Ruim-roxo, ruim-roxo/ Milhões de bandeiras!/ Milhões de castigos!". Os versos se referem aos fascistas, chamados, como se sabe, de "camisas negras", e à SA, força paramilitar nazista dos primeiros anos de Hitler no poder, que seria substituída pela SS e cujos membros eram conhecidos como os "camisas pardas". Assim, pode-se dizer que "O grifo da morte", ao mesmo tempo em que se constitui como um rito de passagem para o não-ser, é também uma meditação sombria sobre a história contemporânea.

740 As expressões entre aspas são do próprio escritor. Andrade, Mário de. "Maleita - I e II", in Táxi e crônicas no Diário Nacional, op. cit., pp. 361-365.
} 
objeto, do ser no não-ser, como uma experiência brasileira ${ }^{741}$, mas não submete essa experiência à distância, muito pelo contrário: os poemas "vivem com religião", como dizia o escritor, todos esses transes. Em seus versos, Mário procura ressentir até o fim, sob as suas mais variadas formas, a experiência paradoxal de que o mesmo é o outro. Desse modo, ao mesmo tempo em que sua poesia apreende e praticamente leva ao esgotamento as aporias nacionais, ela as reproduz, prendendo-se no círculo sem saída da matéria a que aspira dar forma e superar.

No caso do amor, o poeta percebeu que essa lógica infeliz prende-se a estruturas históricas: "Ôh, doce amiga, é certo que seríamos felizes/ Na ausência deste calamitoso Brasil!...", exclama o eu-lírico dos "Poemas da amiga"742. No "Acalanto do seringueiro", onde esse vínculo com a matéria brasileira se evidencia, o amor-de-amigo se consuma na identificação mortal propiciada por uma espécie de hipnose materna, que induz o outro a regredir ao seio indiferenciador de uma mãe primordial, em que se aniquila o indivíduo - como se sabe, por meio da hipnose instaura-se um processo de absorção ritual do outro, em que este é levado a entregar a própria vontade ao hipnotista, com o qual acaba por confundir-se inteiramente ${ }^{743}$. Assim, pensando no sistema teórico de José Antonio Pasta Jr., a berceuse nacionalista encena dramaticamente - a passagem do mesmo no outro, que é também, nesse caso, a passagem da vida na morte, a da cultura na natureza, a da consciência na inconsciência, a da palavra na música. Nessas passagens, e somente nelas, o Brasil se constitui, sob a forma de um obscuro vínculo cultural que irmana o eu-lírico e o seringueiro constituição todavia paradoxal e ruinosa, uma vez que se realiza por meio da dissolução do indivíduo, da cultura, da razão, da linguagem etc. Noutros termos, é como se a cultura brasileira não pudesse unificar-se senão no trânsito para a natureza e, no limite, para o não-ser, e como se a identidade nacional não pudesse formar-se senão por meio

\footnotetext{
741 Nos "Poemas da negra", por exemplo, o corpo do eu-lírico se volatiliza e confunde com os ventos mornos de Pernambuco. No "Rito do irmão pequeno", o exercício agônico da preguiça é desejado como uma negação da civilização utilitarista burguesa.

${ }^{742}$ Idem. "Poemas da amiga", in Remate de males, in Poesias completas, op. cit., p. 275.

743 Heusch, Luc de. "Possédés somnambules et chamans allucinés", in La transe, Bruxelas: Complexe, 2006, pp. 69-84.
} 
da supressão de toda identidade: ‘a questão ‘quem sou eu?’ desagrega-se na queda no sono, $[\ldots .$.$] que mergulha o sujeito em si - fora de si tombado" " 744$.

Conforme dito, no "Acalanto", o momento da passagem do ser no não-ser coincide com a passagem, presidida pela berceuse, da palavra na música. "Balanço entre o nada e o ser, entre nada e ser alguma coisa, ser nada, [...] quase nada"745, a berceuse, que tem afinidades eletivas com a marcha fúnebre, instaura o trânsito para o não-ser, por meio do qual o eu-lírico espera nada menos que "obter" a nação. Em verdade, a música mesma, não apenas sob a forma do acalanto, tem uma natureza crepuscular, constitui essa passagem contínua para o não-ser, considerando-se que o som, como disse Hegel, "é uma exteriorização que destrói a si mesma e no próprio momento em que nasce" 746 . Por isso, porque a música realiza em si mesma a passagem da matéria para o espírito, o filósofo alemão a colocou no limite entre as artes materiais e as artes espirituais. Noutros termos, a música ainda é um fenômeno e não é mais um fenômeno" ${ }^{747}$. "Ela existe e não existe, ela é uma realidade e uma abstração"748, ela sugere em todos os seus níveis, portanto, a indistinção entre o mesmo e o outro: forma e conteúdo, significante e significado, verticalidade e horizontalidade, transitividade e permanência, movimento e paralisação, na música, são uma e a mesma coisa.

Compreende-se, pois, que as passagens em jogo no "Acalanto" coincidem com o momento em que a palavra, que estabelece distinções, tende a converter-se em música. A própria passagem da palavra para a música, conforme visto, é uma passagem do mesmo no seu outro. Assim, quando o eu-lírico começa a proferir as "frases mágicas" "Meu desejo e pensamento/ Ronda sob as seringueiras" - o poema se desdobra, um verso se destaca entre parênteses e acompanha, repetindo-se como um som constante e

\footnotetext{
${ }^{744}$ Nancy, Jean-Luc, Tombe de sommeil, Paris: Galilée, 2007, pp. 29, 79.

${ }^{745}$ Idem. Ibidem, p. 64

${ }^{746}$ Hegel, G. W. F. Curso de Estética: o Sistema das Artes, op cit., p. 289.

${ }^{747}$ Vale lembrar que todo o Livro azul, que tem em seu núcleo a idéia de limite, procura representar, como disse Lafetá, estados de "fenomenalidade sem fenômenos", ou de "fenomenalidade mínima", nos quais o eu-lírico espera apaziguar os antagonismos que o dilaceravam nos poemas de seu livro anterior, $A$ costela do Grã Cão. Ver Lafetá, João Luiz. Figuração da intimidade, op. cit., p. 167.

${ }^{748}$ Ingarden, Roman. Qu'est-ce qu'une oeuvre musicale?, Paris: Christian Bourgois, 1989, p. 7.
} 
monótono, a recitação do poema e a transmigração do espírito do eu-lírico para a Amazônia: “(...numa indiferença enorme...), (...numa indiferença enorme...)”. As reticências, a repetição dos versos e os parênteses sugerem uma espécie de ressonância continuada, que se renova a cada enunciação. Em carta a Bandeira, com efeito, Mário afirma que o verso "fica batendo que nem o sino do prelúdio de Chopin" $"$. Como se sabe com Freud, a emissão de sons monótonos, em especial por meio da percussão repetida de objetos de metal, é uma das formas clássicas de induzir a identificação hipnótica ${ }^{750}$. O próprio Mário reconhecia o poder da "música monótona, [...] buscando favorecer, pela própria monotonia depauperando a consciência, os efeitos mágicos da encantação"751. No "Acalanto", enquanto a alma do eu-lírico se aproxima do seringueiro, o verso-sino dobra e ressoa, em cadência ritualística, solene, como se acompanhasse um ato religioso, induzindo a passagem do mesmo no outro.

Vale notar que o sintagma - “...numa indiferença enorme..." -, ambíguo como um tema musical, sugere ao mesmo tempo a distância extrema que separa os dois brasileiros, distância que os torna indiferentes um ao outro, e a supressão dessa mesma distância, supressão que cancela toda diferença entre ambos. Em outras palavras, o verso significa, simultaneamente, a alteridade absoluta e a identidade completa, portanto ele concentra em si mesmo a ambigüidade central do poema, cuja atmosfera é saturada de hibridismos. Como o leitor terá notado, essa ambigüidade não é uma ambigüidade qualquer. Em sua fluidez semântica, o verso sugere os dois regimes contraditórios de relação intersubjetiva que coexistem, como vimos com Pasta, na sociedade brasileira: um regime que prescreve a diferença entre o mesmo e o outro, e um regime em que essa diferença não é reconhecida.

Não é à toa que o amor, em que também coincidem, na obra de Mário, a alteridade absoluta e a supressão de toda alteridade, instaura-se sob o influxo e à imagem desse verso musical, de que é uma espécie de variação: “(...numa indiferença

\footnotetext{
${ }^{749}$ Andrade, Mário de. Correspondência - Mário de Andrade \& Manuel Bandeira, op. cit., p. 233.

${ }^{750}$ Freud, Sigmund. "Psicologia de grupo e análise do ego", in Obras completas, XVIII, Rio de Janeiro: Imago, 1976, p. 159.

${ }^{751}$ Andrade, Mário de. Pequena história da música, op. cit., p. 17.
} 
enorme...)/ Num amor-de-amigo enorme...". Como mana, a música, no "Acalanto do seringueiro", é a força mágica, misteriosa, que propicia a passagem do mesmo no outro. Ela põe em andamento o rito do amor marioandradino:

\author{
"Meu desejo e pensamento \\ (...numa indiferença enorme...) \\ Ronda sob as seringueiras \\ (...numa indiferença enorme...)
}

Num amor-de-amigo enorme..."

A partir de então, o conteúdo significativo da linguagem praticamente desaparece, reduzido à pura "ordem" de dormir, ao passo que o ritmo e as sonoridades monótonas e repetitivas vêm ao primeiro plano. Nesse momento, o eu-lírico passa a dirigir-se ao seringueiro como "brasileiro", e o poder do acalanto passa a ter efeito. Noutros termos, a nacionalidade, sob a forma do sentimento de grupo, constitui-se apenas no instante da passagem supressiva, propiciada pela música encantatória, do sujeito no seu outro, isto é, a nacionalidade se forma somente à medida que se arruina:

"Seringueiro, dorme!

Num amor-de-amigo enorme

Brasileiro, dorme!

Brasileiro, dorme.

Num amor-de-amigo enorme

Brasileiro, dorme.

Brasileiro, dorme,

Brasileiro... dorme...

Brasileiro... dorme..." 
A transição, nos últimos versos, do ponto final para as vírgulas, e destas para as reticências, sugere a dissolução progressiva da consciência, da linguagem e do próprio poema, o qual se esvai em estrofes cada vez mais reduzidas. As reticências derradeiras, contudo, sugerem que a passagem para o sono, em seus vários níveis, encontra-se no limite de sua própria conclusão, mas não se completa. Como outros poemas de Mário, o "Acalanto do seringueiro" termina sem terminar, em uma espécie de deslizamento infinito para o não-ser, movimento que encontra na berceuse uma de suas formas por excelência, uma vez que ela "torna definitivo o transitivo", como disse Jankélévitch ${ }^{752}$.

Não se deve subestimar o quanto há de desespero nesse poema, onde a formação cultural brasileira somente pode tomar corpo em contexto agônico, desmanchando-se, onde a identificação com o "irmão" da terra pode dar-se apenas à custa da supressão do outro, dada a ausência de mediações - em especial, a ausência da linguagem comum que permitam a instituição de uma relação. Em carta a Bandeira, Mário definiu o “Acalanto do seringueiro" como um poema "trágico, dolorosíssimo", e afirmando que o núcleo dessa tragédia está justamente no problema da linguagem: "Fiz uma espécie de cantiga de berço [...]. É muito comprido, senão mandava. Trágico, dolorosíssimo em eu quero cantar pro tal de seringueiro dormir e não acho 'a palavra brasileira que faça você dormir'. Hei de te mandar. Quis exprimir nessa poesia este mal-estar de pátria tão despatriada"753. O trágico, como vimos com Goethe e Kierkegaard, é a contradição "inconciliável” e "sofredora", que não permite qualquer solução. Nessa linha, em seus diários da Amazônia, escritos dois anos após o "Acalanto do seringueiro”, Mário afirma que a "dor dos irreconciliáveis vive aqui" - isto é, no Brasil -, uma vez que falta ao país, segundo ele, uma "civilização" própria, "por detrás" do indivíduo ${ }^{754}$. Como se sabe, a única "solução" para o conflito trágico é a solução sacrificial: às contradições

\footnotetext{
752 Jankélévitch, Vladimir. Liszt: rhapsodie et improvisation, op. cit., p. 145.

${ }^{753}$ Andrade, Mário de. Correspondência - Mário de Andrade \& Manuel Bandeira, op. cit., 233.

${ }^{754}$ Idem. O turista aprendiz, op. cit., pp. 148-149.
} 
que não o permitem encontrar a linguagem brasileira, Mário responderá, muitas vezes, com o sacrifício da linguagem, por meio da conversão da palavra em música.

A contradição "inconciliável" que está na base do problema da "linguagem brasileira" encontra-se, conforme visto, no núcleo, como tema e como forma, do poema "O trovador", de Paulicéia desvairada, do qual é preciso concluir a análise, para que se demonstre em sua totalidade o movimento do esforço realizado por Mário de Andrade para obter a língua capaz de formular a experiência do país.

Pode-se dizer que a questão da língua nacional aparece em "O trovador" sob a forma de um impasse: constituído por uma "imundície de contrastes" - a expressão é do próprio Mário, que a empregou referindo-se ao Brasil e aos brasileiros ${ }^{755}$-, o poeta brasileiro deve expressar-se em uma língua nativa, que lhe falta, mas não pode obter uma linguagem que não seja estrangeira - dualidade irredutível, traduzida na imagem do tupi tangendo um alaúde, que se encontra no final do poema, sintetizando a identificação e a dissociação concomitantes do artista nacional em relação à cultura européia. Noutros termos, o "trovador" modernista se vê condenado, no Brasil, a oscilar entre a ausência de linguagem original e a linguagem européia, portanto entre o não ser e o ser outro, segundo a conhecida formulação de Paulo Emílio, por meio da qual o crítico definiu a dialética de nossa cultura - dialética negativa, que Mário de Andrade teve o mérito de levar até o fim: "Não somos europeus nem americanos do norte, mas destituídos de cultura original, nada nos é estrangeiro, pois tudo o é. A penosa construção de nós mesmos se desenvolve na dialética rarefeita entre o não ser e o ser outro" $" 756$.

A solução para esse trágico impasse, como vimos, estaria para Mário no “desrecalque localista", o que significa, no plano da língua, desenvolver uma linguagem enraizada na matéria histórica local e capaz de apreendê-la. Vimos também, contudo, que a elaboração dessa linguagem, dadas as contradições insolúveis envolvidas no programa nacionalista da Mário, somente se consuma quando a palavra é abolida e

\footnotetext{
755 Idem. "Tristão de Ataíde" [1931], in Aspectos da literatura brasileira, op. cit., p. 16.

756 Apud, Arantes, Paulo Eduardo. Sentimento da dialética na experiência intelectual brasileira, op. cit., p. 15.
} 
passa no seu outro, a música. Sendo assim, a expressão "desrecalque localista” é particularmente pertinente em Paulicéia, uma vez que a música, a arte capaz de captar e exprimir a coexistência de contrários na São Paulo dos anos 1920, é também, segundo o desvairismo, o meio de expressão do subconsciente. Considerando-se, de acordo com as observações realizadas nas páginas precedentes, que a passagem da palavra para a música tem uma natureza sacrificial, pode-se dizer que o "desrecalque localista", em Paulicéia desvairada, é uma operação sacrificial.

O sacrifício, entretanto, como temos repetido ao longo deste trabalho, consiste em uma solução paradoxal para as contradições insolúveis que é chamado a resolver: ele reproduz essas contradições no movimento mesmo em que as resolve. A conversão da palavra em música, gesto extremo por que as obras de Mário esperam obter a linguagem brasileira, repõe o problema da falta da linguagem específica, adequada à expressão da matéria local. A música é a linguagem abstrata por excelência, uma vez que "enuncia com a universalidade da forma pura"757. Seu regime é o "regime ambíguo do Espressivo que nada exprime"758, ou seja, ela diz tudo e nada ao mesmo tempo, contém a uma só vez a plenitude de sentido e a ausência de sentido: "a música remete à verdadeira linguagem, uma linguagem na qual o teor mesmo se encontraria revelado, mas ao preço da univocidade" ${ }^{\Re 59}$. Noutros termos, a música sugere que o significado se expressa no significante, e não por meio dele, o que a torna uma linguagem especialmente eloqüente, porém à custa de se tornar, no limite, uma linguagem que diz a si mesma. Por isso, segundo Benjamin, “a música é a última linguagem universal depois da torre de Babel"760, nela reside a lembrança da linguagem anterior à Queda na linguagem significante e na multiplicidade das línguas ${ }^{761}$. Em suma, a busca

\footnotetext{
${ }^{757}$ Schopenhauer, Arthur. O mundo como vontade e representação, op. cit., p. 277.

758 Jankélévitch, Vladimir. La Musique et l'Ineffable, op. cit., p. 94.

${ }^{759}$ Adorno, Theodor W. "Fragment sur les rapports entre musique et langage”, in op. cit., p. 5, grifo meu.

760 Benjamin, Walter. Origem do drama barroco alemão, op. cit., p. 235.

${ }^{761}$ Idem. "On language as such and on the language of man", in Reflections, New York: Schocken, 1989, pp. 314-332.
} 
marioandradina da linguagem específica brasileira culmina, em seus momentos extremos, na produção da mais "inespecífica" das linguagens.

Ao longo de suas reflexões estéticas, Mário de Andrade revela-se ambivalente em relação à ausência de significado intelectual da música. Por um lado, em inúmeros momentos de sua obra, ele fez a crítica da "precariedade utilitária da linguagem" e da restrição da palavra ao "significado intelectual" e à "terra curta do pensamento lógico"762. A música, segundo essa perspectiva, proporciona ao artista uma expressão liberada do regime do conceito, mais ampla e menos rígida, capaz dar forma a ambigüidades que escapam à razão. Por outro lado, a "incompreensibilidade" do som constituía para Mário um obstáculo à função social da obra de arte e, em especial, um problema para a arte engajada, que deve transmitir mensagens políticas. Em seus textos tardios, mais politizados, Mário valoriza a música vocal, defende o resgate do ethos musical e recomenda aos compositores o emprego de recursos extra-musicais, como os títulos e os prefácios, que esclareçam o sentido das obras ${ }^{763}$. Por não conter “imagens que sejam representações inteligíveis", por "ter em si mesma o objeto da sua representação", a música era considerada por Mário de Andrade a mais pura das $\operatorname{artes}^{764}$ : “única arte que realiza o Movimento Puro, desinteressado, ininteligível”, diz ele ${ }^{765}$. Ora, vimos que Mário condenou a "Arte Pura" durante toda a sua atividade intelectual. Por isso, ao final de sua Pequena história da música, quando prevê, com o triunfo do atonalismo, a consagração da música pura, conclui com angústia: "Esses pensamentos

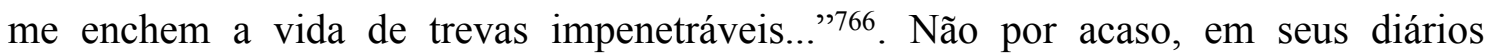
amazônicos, Mário imagina uma tribo de índios brasileiros cuja língua é a música em suas infinitas sutilezas, porém dotada de significados intelectuais muito precisos, de

\footnotetext{
762 Andrade, Mário de. “A linguagem - I” [1929], in Táxi e crônicas no Diário Nacional, op. cit., p. 69; Introdução à Estética musical, op. cit., p. 46; "Castro Alves", in Aspectos da literatura brasileira, op. cit., p. 139.

763 Idem. "Elegia" [1943] e "Introdução a Shostacovich", in Coli, Jorge. Música final, op. cit., p. 110 e pp. 396-407. Não obstante, Mário sustenta, em diversas ocasiões, que a música é "a mais socializadora das artes".

${ }^{764}$ Idem. Namoros com a medicina, op. cit., p. 20; Introdução à Estética musical, op. cit., p. 46.

${ }^{765}$ Idem. Pequena história da música, op. cit., p. 202.

${ }^{766}$ Idem. Ibidem, p. 205.
} 
modo que cada combinação de sons exprime idéias exatas ${ }^{767}$. Vale notar que essa fantasia de uma língua musical entre bons selvagens distingue-se, embora com ela se pareça, da conhecida utopia pré-romântica de Rousseau, em que a linguagem e a expressão musical amorosamente se combinam em uma síntese ${ }^{768}$; na fantasia de Mário, não há síntese superior, mas conversão sacrificial da música e dos valores musicais, que se tornam palavras exatas.

Em “O trovador”, após a conversão festiva da palavra em música, realizada, como vimos, em "Cantabona! Cantabona!"769, a linguagem puramente musical se reduz, no poema, a um ecoar melancólico, a uma evanescência - "Dlorom...". Transformada em música, a linguagem se esvai como o fumo da vítima sacrificial. Consuma-se, desse modo, a tendência à volatilização das palavras que se verifica desde o início do poema, de modo que toda a primeira estrofe - que é quase todo o poema -forma uma espécie de nebulosa de harmonias, na qual se desfazem as oposições - brasileiras - que dissociam o eu-lírico.

O poeta, contudo, diferentemente dos simbolistas, não se compraz em "sugerir o mistério" 770 , pois ele busca, na linguagem misteriosa, a matéria histórica. Não raro, o Brasil aparece na obra de Mário como uma espécie de mysterium fascinans, que está além do maravilhoso e que não pode ser descrito por palavras ou representado por noções claras 771 : “que adianta dizer 'maravilhoso'! não dá a entender o que foi, não posso descrever", diz Mário acerca de uma de suas experiências amazônicas ${ }^{772}$. Em seu diário de viagem, são comuns as passagens que expressam observações parecidas, em que Mário registra seu estupor em relação à natureza e à cultura do país: "Não sei, quero resumir minhas impressões desta viagem litorânea por nordeste e norte do Brasil, não

\footnotetext{
${ }^{767}$ Idem. O turista aprendiz, op. cit., pp. 117-147.

${ }^{768}$ Rousseau, Jean-Jacques. Essai sur l'origine des langues, op. cit..

769 O sacrifício, vale lembrar, é o conteúdo privilegiado da festa. Caillois, Roger. L’homme et le sacré, op. cit., p. 129.

${ }^{770}$ Raymond, Marcel. De Baudelaire ao Surrealismo, op. cit., p. 47.

${ }^{771}$ Sobre o mysterium fascinans, ver Otto, Rudolf. Le sacré, op. cit., pp. 55-86.

${ }^{772}$ Andrade, Mário de. O turista aprendiz, op. cit., p. 66.
} 
consigo bem, estou um bocado aturdido, maravilhado, mas não sei..."773. Assim como o mysterium, o Brasil, além de incompreensível e inefável, aparecia ao autor de Macunaíma como propriamente inconcebível: “[o Brasil] arromba toda concepção que a gente faça dele"774, escreveu Mário no apogeu de sua fase nacionalista, portanto depois de vários anos de pesquisa dedicada a conhecer o país, que se revelava paradoxal em toda linha, uma "imundície de contrastes". Na origem da natureza inapreensível e inconcebível do mistério, está justamente o paradoxo e, no limite, a coincidentia oppositorum. Em 1930, Mário elegeria a vitória-régia como a "flor nacional", como um símbolo do Brasil, uma vez que, composta por "dualidades" e "contradições" de toda sorte, constituía um "mistério profundo", ou melhor, reunia em si uma "mistura de mistérios", que oferecia uma "dificuldade enorme" aos que a procuravam compreender e explicar ${ }^{775}$. Em síntese, mesmo depois de uma década de nacionalismo militante, Mário de Andrade representava seu país como uma "entidade" misteriosa - os estudos e as viagens haviam-lhe tornado o sentido da formação brasileira ainda mais obscuro -, que se oculta no instante mesmo em que se revela.

Mas se o mistério é inacessível às palavras, as palavras, segundo o escritor, tornam-se elas próprias misteriosas à medida que se constituem e organizam como valores musicais 776 . A música, escreveu Mário, constitui um "mistério assombrado"777: em carta de 1928, o escritor sustenta que a música, assim como Deus, somente pode ser objeto de uma "compreensão paralógica"778. Desse modo, diante do mistério nacional, a linguagem marioandradina tenderá a converter-se em música, de modo a expressar e reproduzir o mistério em sua obscuridade mesma. A valorização da sonoridade das palavras, uma das propostas das vanguardas européias, é assimilada por Mário de

\footnotetext{
${ }^{773}$ Idem. Ibidem, p. 59.

${ }^{774}$ Idem. "Sinhô" [1929], in Táxi e crônicas do Diário Nacional, op. cit., p. 84.

775 Idem. "Flor nacional" [1930], in Táxi e crônicas do Diário Nacional, op. cit., pp. 153-154; Idem. Correspondência - Mário de Andrade \& Manuel Bandeira, op. cit., p. 355; Idem. O turista aprendiz, op. cit., pp. 82-83.

776 Idem. "Parnasianismo", in O empalhador de passarinho, op. cit., p. 14.

${ }^{777}$ Idem. "Terapêutica musical”, in Namoros com a medicina, op cit., p. 20.

${ }^{778}$ Idem. Mário escreve cartas a Alceu, Meyer e outros, op. cit., p. 60.
} 
Andrade como um meio privilegiado de apreensão da sociedade brasileira, de modo que a música estará sempre, em sua obra, no horizonte da linguagem que procura dar forma à matéria nacional, matéria estruturada por paradoxos inextricáveis, que roubam o fôlego especulativo e conferem muitas vezes ao país uma feição altamente enigmática e, em casos extremos, misteriosa.

Não são poucas as obras literárias de Mário que assumem em sua estrutura mesma, sob o signo da música, o elemento do mistério. Mencione-se "apenas" Macunaíma, a obra-prima do escritor, em que se revela o desígnio de levar a representação das contradições brasileiras ao esgotamento, e que se conclui, segundo o próprio autor, quando o herói vai para o céu e se transforma em estrela, na “contemplatividade puramente de adoração que existe na reza e no êxtase", no "estado extático de misticismo (religioso) que terá de ser a contemplação da Divindade"779. Macunaíma, que encerra uma profunda reflexão sobre o Brasil, termina portanto com a imagem da contemplação do mistério. Como notou José Antonio Pasta Jr., diferentemente dos enigmas, que pedem decifração, clarificação conceitual, definição, os mistérios demandam contemplação, envultamento, celebração ${ }^{780}$. A obra de Mário de Andrade, que se dedica de forma exaustiva a decifrar e definir o enigma Brasil, não raro suspende-se na celebração do mistério. Sem levar em conta o fundamento históricosocial que explica esse movimento para a obscuridade, um crítico notou todavia com acerto que a "clarificação misteriosa" da realidade constitui um dos princípios de composição mais constantes da lírica de Mário ${ }^{781}$.

A obra de Mário, contudo, pela mesma razão - o esforço de entender e explicar o Brasil - que a leva, em um gesto extremo, a infundir o mistério em suas obras, a praticálo sem distância, recusa igualmente a configuração obscurantista. A suspensão misteriosa contém sempre uma dimensão dramática ou de tristeza na literatura marioandradina - ela é uma das formas que assume o desespero do escritor em relação às possibilidades de apreensão da matéria histórica. Em Macunaíma, por exemplo,

\footnotetext{
${ }^{779}$ Idem. Ibidem, p. 15. Idem, 71 cartas de Mário de Andrade, op. cit., p. 38.

${ }^{780}$ Pasta Júnior, José Antonio. Pompéia: a metafísica ruinosa d’O Ateneu, op. cit., p. 212.

${ }^{781}$ Lima, Luiz Costa. Lira e antilira, op. cit., pp. 47-128.
} 
vimos que a fixação última do herói em estrela não o faz "encontrar a verdade" e constitui a imagem de uma má-infinidade, uma vez que representa a imobilização do herói, e da própria obra, no trânsito entre o ser e o não-ser. Daí a melancolia, assinalada por José Antonio Pasta Jr., das estrelas macunaímicas, de "brilho bonito mas inútil porém”, melancolia que levava Mário de Andrade às lágrimas ${ }^{782}$. Ao mesmo tempo em que a literatura marioandradina tende ao mistério, ela tende, também, à evidência gritante.

Assim, no poema "O trovador”, após a palavra esvair-se em música e a música, em silêncio, o eu-lírico recupera a palavra com nitidez absurda e profere, em fortissimo, uma frase por assim dizer lapidar, em que por fim se formula, em uma espécie de equação, a contradição irresolúvel que o condena à oscilação perpétua entre não-ser e ser outro, e que o levara a saturar a poesia de sugestões musicais e de reticências:

"Sou um tupi tangendo um alaúde!"

Não é por acaso que esse verso se tornou o mais conhecido do nosso modernismo - pelo menos do modernismo do chamado "período heróico", uma vez que o célebre "tinha uma pedra no meio do caminho", de Drummond, pertencente à segunda fase do movimento, lhe disputa a primazia - e deu o nome ao principal estudo já realizado sobre seu autor ${ }^{783}$. A carga de sentido que se concentra na frase é propriamente excessiva: ela pretende nada menos do que sintetizar o paradoxo que constitui a verdade do sujeito e da cultura no Brasil, seu arco de referência recuando, a partir da contemporaneidade, aos séculos anteriores à colonização. Em seu excesso de sentido, a frase aspira a ultrapassar os limites estreitos da linguagem - uma configuração contraditória que José Antonio Pasta Jr. identificou e teorizou ao estudar OAteneu e o romance de Machado de Assis, como se verá logo adiante. Com efeito, o sinal de exclamação tem aqui a significação que lhe atribuiu Adorno, ou seja, a de um

\footnotetext{
782 Pasta, Júnior. José Antonio. "Tristes estrelas da Ursa-Macunaíma”, in op. cit., p. 28.

783 Souza, Gilda de Mello e. O tupi e o alaúde, op. cit..
} 
“desesperado gesto de escrita, que busca em vão escapar para além da linguagem"784. Em virtude da sobrecarga semântica que se condensa no verso, a linguagem é levada a seu limite. O núcleo do sentido do verso, isto é, a afirmação da contradição irresolúvel, mais precisamente do paradoxo de que o mesmo é ao mesmo tempo o mesmo e o outro, contribui para esse movimento, em que a palavra pretende exceder a si mesma.

Isso posto, o leitor terá notado que a evidência excessiva do verso final de " $\mathrm{O}$ trovador" confina com a obscuridade misteriosa da primeira estrofe do poema. Em verdade, a evidência funciona no poema, e na obra de Mário em geral, segundo um regime especial, complexo e paradoxal, que foi compreendido e exposto por José Antonio Pasta Jr. em sua análise d'O Ateneu. De acordo com o crítico, a linguagem, no romance de Pompéia, caracteriza-se por um "excesso de sentido", isto é, por uma "evidência superlativa" que a conduz ao limiar em que o "despotismo de luz" é também a "obnubilação", em que "a evidência passa no mistério": "o paroxismo da nitidez eleva a voltagem da frase até um ponto de fusão que põe em curto-circuito a evidência e o mistério. O excesso incomportável de sentido, seu paroxismo, precipita-se no seu contrário"785. Em outras palavras, a "pletora de significação" leva as frases d'O Ateneu “a decolar em direção a um além da linguagem, a uma esfera tradicionalmente identificada com a transcendência mística"786.

Desse regime, diz Pasta, o superlativo - que Mário de Andrade, como se sabe, tinha o hábito de utilizar - é uma espécie de "manifestação quintessencial". A ênfase que lhe é constitutiva "assinala um desses raros pontos da linguagem - sob o patrocínio da norma e no âmbito da morfologia regular - em que se dão a ver as afinidades virtuais entre intensificação de sentido e a esfera mágico-religiosa. Nele se guarda algo como um empuxe para o absoluto, no qual a linguagem parece tatear os seus limites" ${ }^{\text {"787. }}$. Modo supremo de magnificação no campo da linguagem, o superlativo absolutiza o significado, pois realiza o "movimento paroxístico que arranca o predicado da esfera

\footnotetext{
${ }^{784}$ Adorno, Theodor W. "Sinais de pontuação", in Notas deliteratura I, op. cit., p. 144.

${ }^{785}$ Pasta Júnior, José Antonio. Pompéia: a metafisica ruinosa d’O Ateneu, op. cit., p. 15. Ver pp. 14-68.

${ }^{786}$ Idem. Ibidem, p. 52.

${ }^{787}$ Idem. Ibidem, p. 38.
} 
das comparações - infinitas e relativizadoras - e o alça de um lance único a uma altura que aspira ao além da linguagem, esfera acima de toda crise de significado, de onde ele pode contemplar, fixo e altíssimo, a luta mesquinha das significações enredadas na sua remissão recíproca e incessante"788. Nesse salto para o Absoluto, a linguagem parece "contradizer o seu aspecto de mediadora por excelência" e postular uma "universalidade imediata", de modo que surge "nimbada pelas auras de uma verdadeira aparição". No superlativo, o paroxismo da evidência se converte em mistério.

A passagem inversa, da obscuridade máxima na evidência obcecante, também se verifica na obra de Mário de Andrade, conforme examinado anteriormente. A lógica, embora invertida, é a mesma da que se encontra no superlativo: o esbatimento de significados - a obscuridade -, quando conduzido até os extremos da indefinição semântica, converte-se em revelação, ou seja, na plenitude de sentido. Mário, vimos, chegou mesmo a expor essa idéia, ao afirmar a "ilimitação" da obscuridade é ela mesma "um limite", no qual o poema, obscuro ao máximo, "se torna claríssimo em sua escureza retinta" - o superlativo, vale notar, não figura à toa na frase: a opacificação superlativa é a transparência superlativa; levada ao limite de si mesma, converte-se no seu contrário. Olhando bem, esse é o próprio movimento que realizam os versos de " $\mathrm{O}$ trovador". Desde as palavras iniciais, vimos, o poema realiza uma progressiva diluição do sentido que culmina na dissolução da palavra em música e, por fim, no silêncio, momento em que a composição se precipita na enunciação hiperdefinida do último verso, a qual, por sua vez, relança a palavra às esferas do mistério. Nessa passagem recíproca da obscuridade na transparência e da transparência na obscuridade, o poema reproduz, sem resolver, a lógica de base da contradição histórica que ele procura, a todo custo, apreender - a lógica ruinosa, nos termos de Pasta, da passagem do mesmo no seu outro: do moderno no arcaico e do arcaico no moderno, do nacional no estrangeiro e do estrangeiro no nacional etc.

Sem risco de exagero, pode-se dizer que a alternância entre mistério e evidência, tal como examinada acima, se verifica em toda Paulicéia desvairada, registrando-se na 
pontuação que atravessa o livro, sob a forma de uma alternância entre reticências (de inspiração impressionista) e pontos de exclamação (de inspiração expressionista) - a presença marcante, ou mesmo o excesso, dos sinais de pontuação em Paulicéia constitui mais um aspecto do caráter musical dos poemas do livro, se considerarmos, com Adorno, que "em nenhum de seus elementos a linguagem é tão semelhante à música quanto nos sinais de pontuação", dada a "essência mimética" deles, que aproxima a escrita da fala ${ }^{789}$. Em outros planos da composição, a conversão recíproca de mistério e evidência se manifesta como oscilação entre versos rarefeitos e gritos hiperconcentrados, entre abstração simbolista e matéria bruta, religiosidade e sátira mordaz - sátira que, praticada sem distância, animada por uma espécie de sacra fúria, reverte na seriedade superlativa da disposição religiosa.

Em “O trovador", como em outros poemas de Paulicéia desvairada, a "dialética negativa" da evidência e do mistério é também a dialética das sugestões musicais e da sentença lapidar. O último verso, de fato, na medida em que realiza uma síntese do poema e arremata a composição com uma imagem de grande efeito, assemelha-se a um "verso de ouro" parnasiano, embora o tema seja modernista. A poética do Parnasianismo, como vimos, emprega segundo Mário a "palavra escultoricamente concebida" ${ }^{990}$. Com efeito, destacada do conjunto do poema, encerrando em si mesma um pensamento de ordem geral, a frase assume o aspecto de uma inscrição, como o epitáfio gravado em pedra por Macunaíma logo antes de deixar o mundo. Mas assim como o "herói de nossa gente" inscreve na laje que "não veio no mundo pra ser pedra" e sobe ao céu logo após gravar a sentença, o verso lapidar de "O trovador" contém sua própria negação e aponta para além dos limites a que o "estado de pedra" submete a linguagem ${ }^{791}$. Noutros termos, assim como a escrita do epitáfio eleva Macunaíma às alturas celestes, o excesso de densidade semântica da fórmula de "O trovador" relança

\footnotetext{
${ }^{789}$ Adorno, Theodor W. “Sinais de pontuação”, in op. cit., pp. 142, 149.

${ }^{790}$ Andrade, Mário de. "Parnasianismo", in O empalhador de passarinho, op. cit., p. 14.

791 O movimento ruinoso de conversão recíproca de volatilização e petrificação foi identificado por José Antonio Pasta Jr. em seu estudo sobre O Ateneu, onde o crítico também se refere a Macunaíma. Ver Pasta Júnior, José Antonio. Pompéia: a metafísica ruinosa d'O Ateneu, op. cit., pp. 249-256.
} 
as palavras às esferas musicais. Esse impulso, vimos, é sinalizado na exclamação, e decorre da própria mensagem da sentença, que declara uma contradição irresolvida.

Presa no impasse histórico que procura formular, a poesia de Mário, em Paulicéia desvairada e além, se elevará regularmente à música, movimento que representa, nesse contexto, um salto metafísico: "Sou um tupi tangendo um alaúde/ E a trágica mixórdia dos fenômenos terrestres/ Eu celestizo em euritmias soberanas", exclama o eu-lírico do "Carnaval carioca"792. Sobre a música, todavia, pesa a "maldição do equívoco", como disse Adorno ${ }^{793}$. Na mesma linha, escreveu Jankélévitch que "ela fornece uma transparência especiosa, que não é senão uma impenetrável opacidade, uma pseudo-evidência que não é senão uma confusão"794. Em outras palavras, na música, a passagem da evidência e do mistério se reatualiza. Não por acaso, poemas como o "Carnaval carioca", a que pertence o verso triunfante acima, em que o poeta celebra a sublimação das contradições históricas por meio da música, costumam encerrar-se em figurações da melancolia. Mário, conforme dito, busca na música o sentido da história, porém a música oculta o sentido no instante mesmo em que o revela, como as aparições sagradas - daí, em certa medida, o desafio que essa poesia representa ao crítico: tendendo ao estatuto da música, a lírica de Mário se apresenta, assim como a arte dos sons, como algo que "se subtrai à 'apreensão' do conceito", que “escapa ao 'olhar teórico"'795.

De certa forma, Mário intuiu que na música, uma vez que ela opera, em todos os seus níveis, a passagem do mesmo no seu outro, se encontra de certa forma a verdade da formação histórica brasileira. Com efeito, dizendo de uma forma um tanto brusca, apreender a essência dessa formação não significa sobretudo em apreender a "misteriosa" passagem do moderno no seu outro, o arcaico, e vice-versa, ou seja, em apreender o movimento desconcertante da modernização conservadora, que parece escapar à apreensão conceitual? Sendo assim, embora a produção de sentido seja

\footnotetext{
792 Idem. "Carnaval carioca", in Clã do Jabuti, in Poesias completas, op. cit., p. 166.

${ }^{793}$ Adorno, Theodor W. "Fragment sur les rapports entre musique et langage", in op. cit., p. 5.

${ }^{794}$ Jankélévitch, Vladimir. La Musique et l'Ineffable, op. cit., p. 124.

795 Mallet, Marie-Louise. La musique en respect, Paris: Galilée, 2002, p. 11.
} 
paradoxal na música - ou por isso mesmo -, a poesia do autor de Café incorporará profundamente a música de ponta a ponta, o que se consuma na produção de um libreto de ópera, no qual Mário disse ter "sugado a musicalidade da música, a pondo no meu texto", "roubando" desse modo o compositor, cujo trabalho posterior se tornara, por essa razão, difícil ${ }^{796}$. Por um lado, intoxicando-se de música, a lírica de Mário dramatiza, de modo eloqüente, estruturas históricas profundas; por outro, contudo, visto que essa incorporação não se realiza de forma distanciada, mas, ao contrário, se dá por meio da supressão das distâncias constitutivas da literatura - entre autor e obra, entre obra e sociedade -, a poesia marionadradina, conforme dito outras vezes neste trabalho, reproduz as estruturas históricas que ela apreende à exaustão. Nesse sentido, a relação dessa poesia com a matéria brasileira tem algo de infernal: ela não se liberta, em momento algum, das contradições sociais que ela quer mimetizar sem mediação - não por acaso, ao refletir, em seu poema derradeiro, sobre o seu próprio destino, o poeta comporá a imagem do rio que o arrasta, sempre, de volta à terra dos homens.

Sob o influxo da música, a poesia de Mário re-presenta, portanto, a obscuridade da matéria brasileira, obscuridade que constitui, como vimos, uma das características anticlássicas do programa "clássico" de formação cultural em que se organiza a obra de Mário de Andrade, programa que tem no seu centro, conforme dito, a elaboração de uma linguagem capaz de formular a experiência brasileira. A esse problema vincula-se também o aspecto difícil que a linguagem nacionalista de Mário muitas vezes assume. A dificuldade dessa linguagem vincula-se especialmente: 1) à constatação de que a formação cultural brasileira é elitista, não integrada e européia; 2) à intenção de criticar e combater a má-formação por meio da exponenciação provocativa dessa mesma falta de integração. Lembre-se, por exemplo, do "Lundu do escritor difícil", onde essa estratégia se explicita e é exercida com bastante virtuosismo, ou da dificuldade do vocabulário de Macunaíma, que inclui um conjunto numerosíssimo de expressões populares e indígenas, de referências a frutas, árvores e animais do Brasil profundo, desconhecidos da maioria dos leitores do livro, formada pelas elites cultas das principais

\footnotetext{
${ }^{796}$ Em uma importante carta sobre o Café, escrita em 1943 para Antonio Candido. Andrade, Mário de. 71 cartas de Mário de Andrade, op. cit., p. 53.
} 
capitais do país. Tratava-se, para o escritor, de uma forma de convidar essas elites a estudar, conhecer e valorizar o próprio país, lançando-lhes ao rosto a sua pouca impregnação nacional, a sua ignorância a respeito da realidade brasileira e a sua adesão ridícula aos valores europeus. Nesse sentido, como escreveu Roberto Schwarz, "a reforma [proposta por Mário de Andrade] dizia respeito prioritariamente às classes cultivadas, instadas a trocar de lealdade", do que aos despossuídos ${ }^{797}$. Supunha, portanto, que as elites poderiam dedicar-se a sanar a falta de cultura nacional orgânica no país, o que implicava diminuir, em alguma medida, a segregação dos pobres:

"Num país como o nosso, em que a cultura infelizmente ainda não é uma necessidade quotidiana do ser, está se aguçando com violência dolorosa o contraste entre uma pequena elite que realmente se cultiva e um povo abichornado em seu rude corpo. Há que forçar um maior entendimento mútuo, um maior nivelamento geral de cultura que, sem destruir a elite, a torne mais acessível a todos, e em conseqüência lhe dê uma validade verdadeiramente funcional. Está claro, pois, que o nivelamento não poderá consistir em cortar o tope ensolarado das elites, mas em provocar com atividade o erguimento das partes que estão na sombra, pondo-as em condição de receber mais luz." 798

O teor paternalista das proposições feitas por Mário na passagem acima dispensa maiores comentários, mas ajuda a compreender um dos lados do projeto nacionalista de formação cultural concebido e posto em prática pelo escritor. No "Lundu do escritor

\footnotetext{
797 "Mário inventava modos de reconhecer direito de cidade à linguagem cotidiana, livrando-a do estigma e relativo confinamento. À primeira vista, a mudança significava a promoção do âmbito popular. Olhando melhor, contudo, notaremos que a reforma dizia respeito prioritariamente às classes cultivadas, instadas a trocar de lealdade". Schwarz, Roberto. "Outra Capitu”, in Duas meninas, op. cit., p. 138.

798 Andrade, Mário de. Carta a Paulo Duarte, 1937. In Duarte, Paulo. Mário de Andrade por ele mesmo, op. cit., pp. 150-151.
} 
difícil”, a dificuldade do poema, por meio da provocação ostensiva, visa justamente à criação, entre o eu-lírico e o leitor, de laços de intimidade marcados pela informalidade avessa à linguagem oficial, vínculos típicos do paternalismo brasileiro. Assim, agredido com graça, o leitor culto é chamado a abandonar a língua "estrangeira" pela nativa. Paradoxalmente, o "estranhamento" é um meio para que certa familiaridade, entendida como peculiar à terra, seja estabelecida entre o eu-lírico, o poema e o leitor:
"Eu sou um escritor difícil
Que a muita gente enquisila,
Porém essa culpa é fácil
De se acabar duma vez:
É só tirar a cortina
Que entra luz nesta escurez." 799

Nesse sentido, a linguagem literária do escritor, conforme dito anteriormente, é extremamente pessoal, o que praticamente impede que ela tenha uma função modelar, ao contrário do que ocorre com as obras clássicas. Como se viu, levado às últimas conseqüências, o propósito marioandradino de trazer à existência uma língua coletiva e nacional paradoxalmente conduziu à constituição de um estilo personalíssimo e, enquanto tal, impossível de ser repetido e de servir como modelo às gerações posteriores.

Em suma, destruição da forma, supressão de distâncias, obscuridade, dificuldade da linguagem e caráter irrepetível, aspectos tradicionalmente opostos à classicidade, não apenas se encontram no projeto formativo concebido por Mário de Andrade, mas são elementos essenciais dele, pois são recursos sem os quais ele não se realizaria, considerando-se as contradições peculiares, irredutíveis e desesperadoras da matéria histórica brasileira, tal como elas se apresentavam para Mário de Andrade nos anos 1920-30.

\footnotetext{
799 Andrade, Mário de. "Lundu do escritor difícil”, in Poesias completas, op. cit., p. 305.
} 
Consumando-se por meio da devastação formal, da identificação ruinosa entre sujeito e sociedade e, muitas vezes, da incomunicabilidade da linguagem, entre outras mediações negativas, o projeto de formação posto em prática pelo autor de Macunaíma realiza-se segundo um regime muito especial, que foi identificado e conceitualizado por José Antonio Pasta Júnior: trata-se do regime da formação supressiva, que expusemos algumas páginas atrás. Conforme visto, o conceito de formação supressiva assinala um regime singular no qual o sujeito "não se forma pelo retorno a si, desde a experiência do objeto - consolidando-se, como identidade, em sua própria esfera - mas se constitui, no extremo de seu desdobramento, passando no seu outro"800. O sujeito somente vem a ser sendo o outro, em um processo cuja outra face está em que, "passando no seu outro, ele vem a ser no e pelo movimento mesmo em que deixa de ser: ele se forma suprimindo$s e^{" 801}$. Sob essa perspectiva, não se trata, na formação supressiva, de formação propriamente dita, que se completa por meio da reflexão, em síntese superior, mas de uma formação paradoxal, que se realiza justamente pela não-formação: "Essa junção de sujeito e objeto é ela própria uma 'síntese' puramente desaparecente, constituindo-se/ dissolvendo-se como uma forma em perpétua evanescência"802. Com efeito, a impressão geral que se tem da obra de Mário de Andrade é a de um monumental conjunto que se constituiu arruinando-se, ou que se cristalizou evolando-se - em suma, de uma obra que, como toda vítima sacrificial, veio a ser deixando de ser, isto é, por meio de sua própria destruição803: “estraçalho a minha obra”, já escrevia Mário em 1924, ainda no início da execução das providências que considerava necessárias para dotar o Brasil de uma cultura... integrada ${ }^{804}$.

\footnotetext{
${ }^{800}$ Pasta Júnior, José Antonio. Pompéia: a metafísica ruinosa d’O Ateneu, op. cit., p. 76.

801 Pasta Júnior, José Antonio. "O romance de Rosa - temas do Grande sertão e do Brasil”, in Novos estudos CEBRAP, n. 55, novembro 1999, p. 64.

802 Pasta Júnior, José Antonio. Pompéia: a metafísica ruinosa d’O Ateneu, op. cit., p. 77.

${ }^{803}$ Herrenschmidt, Olivier. "A qui profite le crime? Cherchez le sacrifiant", in op. cit., pp. 7-18. Hubert, Henri; Mauss, Marcel. "Ensaio sobre a natureza e a função do sacrifício", in Mauss, Marcel. Ensaios de sociologia, op. cit., 166-174.
}

${ }^{804}$ Andrade, Mário de. A lição do amigo, op. cit., p. 6, grifo meu. 
Diante do exposto, é possível concluir que a própria matéria histórico-social brasileira, em suas contradições aparentemente insolúveis, das quais a modernização conservadora é a contradição básica, expressava-se no projeto cultural marioandradino, ao mesmo tempo em que o inviabilizava, levando-o a realizar-se sob a forma paradoxal do sacrifício, portanto por meio da destruição em todos os seus níveis: no subjetivo, no estético e no nacional ${ }^{805}$. De nossa parte, vimos Mário de Andrade declarar, justificar e cumprir a decisão de sacrificar sua obra literária, posteriormente a própria Arte, seus anseios e inclinações pessoais. Após o fracasso do Departamento, portanto depois do "suicídio do artista", Mário parece ter-se dado conta de que seus trabalhos compunham um conjunto colossal de ruínas, pois foi progressivamente tomado "por um sentimento de irremediável destruição"806, uma profunda melancolia, da qual não se libertou até a morte ${ }^{807}$.

Mário de Andrade não se matou, como se sabe, mas não foram poucos os que viram, em sua morte, o resultado de um lento suicídio. "Mário suicidou-se aos poucos, matou-se de dor, revolta e angústia", recordou Paulo Duarte, que se correspondeu intensamente com o escritor durante os últimos anos de vida deste ${ }^{808}$. "Morreu num suicídio de esperança", escreveu Guilherme Figueiredo, outro amigo dos anos finais de Mário $^{809}$. Sobretudo, o próprio escritor expressou, em uma carta de 1942, citando um verso seu, o desejo de morrer e suas causas: "Eu me imaginava participante da vida e agora que sinto toda a minha literatice como um safado abstencionismo, os meus próprios estudos me enojam como uma covardia sem limite. Só existe uma solução: 'Oh

\footnotetext{
${ }^{805}$ Lembre-se que, entre as oblações, a característica distintiva do sacrifício é a de que o objeto oferecido em sacrifício é destruído. Hubert, Henri; Mauss, Marcel. Ibidem, p. 149.

${ }^{806}$ Alvarenga, Oneyda. Mário de Andrade, um pouco, op. cit., p. 108.

807 Sobre a relação entre melancolia e ruína, ver Benjamin, Walter. Origem do drama barroco alemão, op. cit., pp. 165-211.

${ }^{808}$ Duarte, Paulo. Mário de Andrade por ele mesmo, op. cit., pp. 3-4.

${ }^{809}$ Andrade, Mário de. A lição do guru (cartas a Guilherme Figueiredo, 1937-1945), op. cit., p. 23.
} 
sono, vem! que eu quero amar a morte - Com o mesmo engano com que amei a vida'. Um suicídio discreto, mui discreto, não fica mal"\$10.

Conforme o leitor terá notado, as razões que levam Mário de Andrade a desejar a morte decorrem da natureza contraditória da própria solução sacrificial dada pelo escritor aos impasses a que o conduziram os esforços, por ele empreendidos, de aproximar arte e sociedade no Brasil. Já em um poema de 1926, portanto em plena fase nacionalista, Mário meditava com pesar sobre a inutilidade do sacrifício de si mesmo, sugerindo a intenção de matar-se:

"Eu só desejo uma calma

Que apagasse até meus ais!

Tudo amarga porque os homens

Me amargaram por demais!

Uma tristeza profunda,

Uma fadiga profunda,

E até, miseravelmente,

O projeto inconfessável

De parar..." 811

A morte foi o sacrifício extremo e derradeiro a que as contradições em que se dilacerava Mário de Andrade o conduziram. Não havia como ir além: “esse dom total é o máximo de que um homem é capaz: pois nenhum homem pode dar mais que seu próprio ser" ${ }^{\prime \prime 12}$.

\footnotetext{
810 Andrade, Mário de. Cartas a Murilo Miranda (1934-1945), op. cit., p. 100. O verso citado por Mário pertence ao soneto "Quarenta anos", um dos poemas de $A$ costela do Grã-Cão.

811 "Reconhecimento de Nêmesis", in Poesias completas, op. cit., p. 304.

812 Jankélévitch, Vladimir. La mort, op. cit., p. 229.
} 
Parte III 


\section{Dioniso}

"Não danço mais dança-do-ombro!

Eu reconheço que sofro!”

Mário de Andrade. "Reconhecimento de Nêmesis" [1926].

“Alegrias bombásticas

Sofrimentos redundantes

Retumbantes

Samba

$[\ldots]$

Sangue

Pranto e riso

Quanta coisa! Quanta coisa!”

Mário de Andrade. "Reza de fim de ano" [1923]. 
A presença decisiva da estrutura sacrificial no coração do pensamento e da obra de Mário de Andrade contrasta, à primeira vista, com o gosto da vida que não raro se exprime na literatura, na reflexão teórica e na correspondência do escritor. Em carta de 1924 ao jovem Drummond, Mário convida o amigo a deixar o "gabinete" e a entrar em contato direto com a natureza e com a sociedade, ou seja, a largar um pouco os livros e a "viver" mais: "Eu acho, Drummond, pensando bem, que o que falta pra certos moços de tendência modernista brasileiros é isso: gostarem de verdade da vida. Como não atinaram com o verdadeiro jeito de gostar da vida, cansam-se, ficam tristes ou então fingem alegria, o que ainda é mais idiota do que ser sinceramente triste. Eu não posso compreender um homem de gabinete e vocês todos, do Rio, de Minas, do Norte me parecem um pouco de gabinete demais. Meu Deus! se eu estivesse nessas terras admiráveis em que vocês vivem, com que gosto, com que religião eu caminharia sempre pelo mesmo caminho (não há mesmo caminho pros amantes da Terra) em longas caminhadas! Que diabo! estudar é bom e eu também estudo. Mas depois do estudo do 
livro e do gozo do livro, ou antes vem o estudo e gozo da ação corporal"813. Ao ceticismo fin de siècle, ao pessimismo diletante e à erudição livresca, associadas por Mário à influência da cultura européia, em especial da francesa, o autor de Paulicéia desvairada opõe o otimismo nativista, a conversa com a gente do povo, a "farra vital". Com a intenção de animar o poeta mineiro, Mário expõe o seu próprio exemplo: "Eu sempre gostei muito de viver, de maneira que nenhuma manifestação da vida me é indiferente. Eu tanto aprecio uma boa caminhada a pé até o alto da Lapa como uma tocata de Bach" ${ }^{\prime 14}$. Algumas semanas depois, ele escreveria a Manuel Bandeira no mesmo sentido: "Sou um sujeito que vive na extensão gostosa da palavra. Nada de gabinete. Homem na rua. Puxa! como cansa escrever deitado! Tenho um poder de festas, de convites, amizades, passeios que satisfaço religiosamente. [...] Eu já disse pra você que vivo gostando" 815 . Com efeito, ao contrário do sofredor que foi estudado até o momento neste trabalho, Mário exclamava com freqüência e entusiasmo, segundo Paulo Duarte, como uma espécie de bordão da própria vida: "Sou um homem feliz!"816.

Esse outro Mário é o Mário do riso, o Mário da festa. Ficaram conhecidas as suas gargalhadas, que lhe sacudiam o corpo todo, e não são poucos os que recordam "o sorriso mais alegre deste mundo", "aqueles risos imensos", de "abrir o crânio", do autor de Macunaima ${ }^{817}$. A grande risada encontrou no ambiente modernista o seu lugar por excelência: "Sou o primeiro a ver Tarsila e Osvaldo no cais, nos esperando de surpresa. Alegria sem limites mais. Passeios às gargalhadas. [...] Que pensar em dormir nem nada! conversas paulistas, blagues, artes. Osvaldo aparece num paletó mirabolante, amarelo, pardo e preto, numa completa ausência de malícia"\$18. A piada, como se sabe, era uma das grandes armas usadas pelo modernismo brasileiro contra a velha moral em que se baseava a estética passadista, importada dos europeus; desse modo, o humorismo

\footnotetext{
${ }^{813}$ Andrade, Mário de. A lição do amigo, op. cit., p. 4.

${ }^{814}$ Idem. Ibidem, pp. 3-4.

${ }^{815}$ Idem. Correspondência - Mário de Andrade \& Manuel Bandeira, op. cit., pp. 181-182, grifo do autor.

${ }^{816}$ Duarte, Paulo. Mário de Andrade por ele mesmo, op. cit., p. 51.

817 Andrade, Mário de. "Uma excursão ao Rio Amazonas" [entrevista de 1927 ao Diário Nacional], in Entrevistas e depoimentos, op. cit., p. 26. Duarte, Paulo. Mário de Andrade por ele mesmo, op. cit., p. 50.

818 Andrade, Mário de. O turista aprendiz, op. cit., pp. 175-176.
} 
desimpedido associava-se à idéia de uma sociedade "inocente", liberada dos recalques que estruturavam a civilização burguesa decadente. A poesia pau-brasil deve ser "como uma criança", proclama Oswald de Andrade, para quem a "a poesia está nos fatos", antes que nos livros: "contra o gabinetismo, a prática culta da vida", ele defende "o estado de inocência"819. Na poesia - e na prosa - de Oswald, esse humor "natural", que se opõe às complicações artificiais, fraudulentas, que enredavam as coisas do espírito, associa-se à simplicidade formal, antiilusionista e bastante moderna, das fórmulas matemáticas: "A alegria é a prova dos nove", declara o "Manifesto Antropófago" 820.

Nas obras de Mário, a blague assume outras formas, mas não deixa também de marcar a produção do escritor, em especial durante o decênio de 1920. A poesia de Paulicéia desvairada, como vimos anteriormente, traveste-se do Arlequim da commedia dell'arte, satiriza os costumes da burguesia paulistana e escarnece da cidade sem alegria, afrancesada, onde não é permitido cantarolar nem vagar sem destino. Essa constelação formada por nativismo, zombaria e inocência se configura plenamente na rapsódia Macunaíma, que "não passa duma brincadeira", de acordo com Mário: "Fiz o que me vinha na cabeça unicamente me divertindo e nada mais" ${ }^{\prime 21}$. Assim como seu autor, também o herói de nossa gente, mesmo nos momentos mais dramáticos, vive suas aventuras divertindo-se, rindo muito: "Macunaíma deu uma gargalhada" faz parte do grupo de frases que se repetem inúmeras vezes ao longo do livro.

Entre outras coisas, o aspecto satírico-jocoso de Macunaíma funciona como crítica da ideologia burguesa do trabalho. Em uma entrevista a um jornal paulista sobre a Amazônia, o escritor procura desfazer a idéia, sugerida pelo jornalista, de que a gente do norte não gosta de trabalhar por causa do calor tropical; refere-se, então, numa

\footnotetext{
819 Andrade, Oswald de. "Manifesto da Poesia Pau-Brasil", in Obras completas, VI - Do pau-brasil à antropofagia e às utopias: manifestos, teses de concursos e ensaios, Rio de Janeiro: Civilização Brasileira, 1972, pp. 5-7.

820 Andrade, Oswald de. "Manifesto Antropófago", in op. cit., p. 18. Sobre as contradições internas da poesia pau-brasil, ver Schwarz, Roberto. "A carroça, o bonde e o poeta modernista", in Que horas são?, op. cit., pp. 11-28. Sobre o caráter moderno, industrial, sintético e objetivo da poética de Oswald, em contraste com a "palavrosidade", o sentimentalismo e o "simbolismo renitente" da arte de Mário, ver Campos, Haroldo de. "Uma poética da radicalidade", de Haroldo de Campos, in Andrade, Oswald de. Pau-Brasil, op. cit., pp. 7-27.
} 
comparação implícita com a sisudez do homens de São Paulo, à possibilidade de conjugarem-se, mesmo em contexto de exploração intensa da mão-de-obra, trabalho e diversão: "O tapuia trabalha muito, trabalha bem e é alegríssimo. Para ganhar uma ninharia, quase degradante, a tapuiada passa uma noite inteira, carregando lenha para dentro dos navios. Tudo isso no meio de ditos e gargalhadas..." ${ }^{\text {222 }}$. A defesa da reunião de prazer e trabalho levará Mário de Andrade, em alguns momentos de sua obra, à recusa do trabalho alienado, do trabalho como sacrificio, nos termos com que Adam Smith concebeu e defendeu o regime capitalista de mão-de-obra, concepção de que Marx denunciou a natureza ideológica ${ }^{823}$; as soluções de Mário contra a alienação, contudo, costumam ser sacrificiais elas mesmas, como no "Rito do irmão pequeno", conforme visto anteriormente, ou nas crônicas sobre a maleita, onde a "indiferença extasiada", a "morte virginal" ou a "preguiça organizada" propiciadas pela doença aparecem como alternativa a "nossa idiotíssima civilização importada"824. Voltemos, entretanto, ainda uma vez, ao Mário que tem o gosto da sátira e do humor, para registrar que o escritor, perguntado em outra entrevista sobre quais os seus escritores preferidos, afirma que é difícil responder, mas que, em todo caso, Molière e Cervantes, dois mestres do cômico, estão entre os autores de que mais gosta ${ }^{825}$.

O riso de Mário é o riso da festa. Em carta a Bandeira, o autor de Paulicéia descreve a "pândega" que foi o baile futurista, que houve em 1924 na "alta roda" paulistana, festa para a qual Mário escreveu "dísticos estrambóticos e divertidos": "Em vez de voltar do baile a uma hora, voltei às seis e trinta, pleno dia. Esteve estupendo. [...] Uma pândega. Em vez de sapear só, sapeei e dancei. O jazz estava engraçadíssimo. Alegria assim nunca se viu nesta gente macambúzia da minha cidade"\$26. Nessa linha,

\footnotetext{
822 Idem. "Uma excursão ao Rio Amazonas", in Entrevistas e depoimentos, op. cit., p. 28.

823 Marx, Karl. “Adam Smith. El trabajo como sacrificio”, in Elementos fundamentales para la crítica de la economía política (Grundrisse) 1857-1858, II, México: Siglo Veintiuno, 2007, pp. 118-125.

824 Andrade, Mário de. "Maleita I e II" [1931], in Táxi e crônicas no Diário Nacional, op. cit., pp. 360-365. No ensaio tardio "O artista e o artesão", Mário esboça a idéia de um trabalho livre. Idem. "O artista e o artesão" [1938], in O baile das quatro artes, op. cit., pp. 11-33.

825 Idem. "Resposta ao inquérito sobre mim pra Macaulay", in Entrevistas e depoimentos, op. cit., p. 40.

${ }^{826}$ Idem. Correspondência - Mário de Andrade \& Manuel Bandeira, op. cit., pp. 154-155.
} 
na conhecida conferência sobre o movimento modernista, Mário recorda os salões dos anos 1920 em São Paulo, promovidos pelos "aristocratas regionais", os "Prados e Penteados e Amarais", em que se reuniam os jovens artistas e a "elite ilustrada" da cidade: "E vivemos uns oito anos, até perto de 1930, na maior orgia intelectual que a história artística do país registra" 827 . A Semana de Arte Moderna teria sido "a primeira festa", de tantas outras que se seguiram pelo decênio do "período heróico" do movimento: "Todo esse tempo destruidor do movimento modernista foi pra nós tempo de festa... de cultivo imoderado do prazer. E si tamanha festança diminuiu por certo nossa capacidade de produção e serenidade criadora, ninguém pode imaginar como nos divertimos. Salões; festivais, bailes célebres, semanas passadas em grupo nas fazendas opulentas [...]. Tudo consumíamos, e a nós mesmos, no cultivo amargo, quase delirante, do prazer" $" 828$.

As festas de Mário, porém, não são tanto os bailes ou salões das elites, que ele freqüentou com assiduidade, mas sempre com "tal ou qual constrangimento", causado pela "imponência de riqueza e tradição no ambiente" ${ }^{29}$. As festas de Mário são, sobretudo, as festas populares. Em fevereiro de 1923, escreve a Manuel Bandeira, narrando a experiência do carnaval do Rio de Janeiro, que o absorveu por completo, ao ponto de fazê-lo deixar de visitar seus amigos: "Meu Manuel... Carnaval!... Perdi o trem, perdi a vergonha, perdi a energia... Perdi tudo. Menos minha faculdade de gozar, de delirar... Fui ordinaríssimo. [...] Manuel: sem comprar um lança-perfume, uma rodela de confete, um rolo de serpentina, diverti-me 4 noites inteiras e o que dos dias me sobrou do sono merecido. E aí está porque não fui visitar-se" 830 . O carnaval carioca aparecia a Mário de Andrade, então, como uma autêntica festa popular, muito diferente da versão paulista, ordeira e elitista: "Meu cérebro acanhado, brumoso de paulista, [...] nunca seria capaz de imaginar um carnaval carioca, antes de vê-lo. Imaginei-o paulistamente. Havia um quê de neblina, de ordem, de aristocracia nesse delírio

\footnotetext{
${ }^{827}$ Idem. "O movimento modernista", in Aspectos da literatura brasileira, op. cit., p. 261.

828 Idem. Ibidem, p. 264.

${ }^{829}$ Idem. Ibidem, p. 263.

${ }^{830}$ Idem. Correspondência - Mário de Andrade \& Manuel Bandeira, op. cit., pp. 84-85.
} 
imaginado por mim. Eis que sábado, às 13 horas, desemboco na Avenida. Santo Deus! Será possível! [...] Admirei repentinamente o legítimo carnavalesco, o carnavalesco carioca, o que é só carnavalesco, pula e canta e dança quatro dias sem parar. Vi que era um puro! Isso me entonteceu e me extasiou. O carnavalesco legítimo, Manuel, é um puro" 831 .

Em sentido análogo, no final de 1929, Mário lamenta ter passado a noite de Natal em São Paulo, e não no Rio Grande do Norte, como fizera no ano anterior, tendo em vista a natureza artificial, importada e particular da comemoração paulistana, em comparação com o caráter autêntico, público e popular que a festa assume no Nordeste: “O ano passado eu gozei a noite-de-festa no Rio Grande do Norte, lá. Este ano fui obrigado a gastar aqui mesmo essa noite que nós nem expressão brasileira temos pra designar: chamamos de noite de Natal, como toda gente. [...] Deus me livre de negar que aqui também se goza, dizer que não me diverti, diverti sim, porém num prazer de importação pro qual fui apenas convidado. Lá eu era também dono da casa, a festa era minha também. Aqui, vivemos todos numa festa dos europeus e da França. A diferença é enorme. [...] Um Papá Noel entre coxilhas alemãs ou suíças, passar num trenó de neve, puxado a renas, corresponder a pinheiros enfeitados nas famílias, bailes de 'jazz' falsificado, castanhas européias, nozes. E a alegria dos convidados, nós. Não tem Lapinhas mais, e nem sei que tenha tido seus Pastoris. Minha noite de festa lá na capital do Rio Grande do Norte também teve castanhas, mas de caju, nacionais. [...] A Chegança, puxando um barquinho de mentira, lindo, vela enfunando ao vento grande do Nordeste. [...] Lapinhas em cada canto. Pastoris de criança. Pastoris de moças. A mestra do Cordão. [...] E a alegria dos donos da festa, todos nós. A diferença é enorme" ${ }^{832}$. Como se sabe, a Chegança, o Pastoril, a Lapinha e o Cordão fazem parte do conjunto de bailados populares brasileiros designados por Mário de Andrade como "danças dramáticas", das quais o Bumba-meu-Boi, segundo o escritor, é a principal; para Mário, as danças dramáticas constituíam uma das manifestações mais características da cultura

\footnotetext{
${ }^{831}$ Idem. Ibidem.

${ }^{832}$ Idem. "Noite de festa", in Táxi e crônicas no Diário Nacional, op. cit., pp. 149-150.
} 
popular nacional: "Nisso o povo brasileiro evolucionou bem sobre as raças que nos originaram e as outras formações nacionais da América. Possuímos um grupo numeroso de bailados, todos providos de maior ou menor entrecho dramático, texto, músicas e danças próprias" ${ }^{833}$. No pensamento de Mário de Andrade, o carnaval e as danças dramáticas são as festas por excelência.

À vista disso, pode-se dizer, sem risco de exagero, que o Mário festeiro, orgiástico, profano, o Mário que goza a vida, embora aparente ser o contrário do Mário sacrificial, no fundo é idêntico a ele. Com efeito, vale lembrar, antes de mais nada, que o sacrifício é uma espécie de conteúdo privilegiado da festa: “O sacrifício é algo como o movimento interior da festa, aquilo que a resume e lhe dá sentido. Eles aparecem juntos segundo a mesma relação que a alma e o corpo mantêm entre si. [...] A dialética da festa reproduz a dialética do sacrifício" 834 . No núcleo da festa está a idéia da destruição dos bens como forma de renovação da natureza e da sociedade, portanto o princípio do sacrifício; além disso, a exaltação coletiva, contagiosa, que se exprime em um frenesi de gritos e gestos, e que tende à violência, uma vez que estimula o indivíduo a abandonarse às impulsões mais irrefletidas, confere à festa uma inequívoca atmosfera sacrificial, ainda que ela não seja uma festa sagrada ${ }^{835}$.

Embora não o mencione de maneira explícita, Bakhtin encontrou o sacrifício no centro do sistema de imagens da mais profana das festas, o carnaval. Sabe-se que o principal episódio do carnaval tradicional consiste na entronização-e-destronização do rei-bufo; depois de eleito pelo povo, o rei é injuriado e linchado pelo mesmo povo que o elegeu: as injúrias e os golpes destronam o soberano, metendo-o a ridículo. Como sugere o próprio crítico, o episódio assemelha-se à história bíblica da coroação, da flagelação e da ridicularização do "rei dos Judeus", o que assinala o sentido sacrificial da deposição do rei-bufo no carnaval. De acordo com Bakhtin, as descrições do aviltamento coletivo do bufão não raro incluem, de fato, imagens do despedaçamento do corpo do protagonista, de modo que o crítico chega a empregar em sua obra expressões

\footnotetext{
${ }^{833}$ Idem. Danças dramáticas do Brasil, op. cit., p. 31.

${ }^{834}$ Caillois, Roger. L'homme et le sacré, op. cit., p. 129.

${ }^{835}$ Idem. Ibidem.
} 
como "a vítima do carnaval" ou "a vítima cômica", para referir-se a esses palhaços humihados ${ }^{836}$. Em uma frase lapidar, Mário de Andrade representa a si mesmo, em seus esforços para modernizar e nacionalizar as letras no Brasil, como uma dessas vítimas cômicas, numa imagem que remete ao Cristo e que associa o sacrifício, o corpo despedaçado, a ridicularização e o Brasil - como temos visto, a solução sacrificial, na obra de Mário, prende-se às contradições histórico-sociais brasileiras, assim como as manifestações contraditórias do gozo marioandradino, conforme veremos adiante: "Mas vivo remendadamente no Brasil, coroado com os espinhos do ridículo"837.

A morte simbólica do rei-bufo, entretanto, significa ao mesmo tempo um renascer; o carnaval configura um mundo ambivalente que agoniza e renasce ao mesmo tempo, ou seja, um mundo que rejuvenesce por meio de seu próprio perecimento - por isso, entre outras coisas, os golpes e injúrias contra os bufões são sempre alegres atos festivos ${ }^{838}$. Ora, segundo Mário de Andrade, “o pensamento elementar de morte e ressurreição", justamente, constitui um elemento essencial comum à maioria das nossas danças dramáticas ${ }^{839}$. A mais complexa e nacional delas, o Bumba-meu-Boi, tem em seu núcleo, como vimos, a representação do sacrifício simbólico do boi, que renasce ao final do bailado por meio de práticas mágico-religiosas: a imolação do boi era considerada por Mário de Andrade, conforme dito, uma espécie de momento de verdade do Brasil, em que as contradições nacionais de precipitavam numa resolução paradoxal. O sacrifício por sparagmós do animal bovino é uma prática central, também, de grande parte das festas dionisíacas, de modo que o próprio deus, não raro, assume as formas do touro e do boi. Dioniso, "por excelência o deus da festa", vinculado desde as suas origens arcaicas ao princípio de morte e ressurreição da natureza, integra ele mesmo o

\footnotetext{
${ }^{836}$ Em outro contexto, as afinidades históricas entre as figuras do rei decaído, do clown e do ser mutilado são abordadas por Adorno em seu conhecido ensaio sobre Fim de partida, de Beckett. Adorno, Theodor W. "Pour comprendre Fin de partie", in Notes sur la littérature, Paris: Flammarion, 1999, pp. 201-238.

837 Andrade, Mário de. A escrava que não é Isaura, in Obra imatura, op. cit., p. 266.

838 Bakhtin, Mikhail. A cultura popular na Idade Média e no Renascimento: o contexto de François Rabelais, São Paulo: Hucitec, 2008.
}

${ }^{839}$ Andrade, Mário de. Danças dramáticas do Brasil, op. cit., p. 33. 
grupo dos deuses sacrificados, assassinados e renascidos ${ }^{840}$. No dionisismo, "a natureza exuberante celebra as suas saturnais e os seus funerais ao mesmo tempo", escreve Nietzsche, em uma formulação cheia de conotações sacrificiais ${ }^{841}$.

O prazer marioandradino é essencialmente dionisíaco. Nesse sentido, ele supõe sempre a hybris, ou seja, a desmedida: "amo irrefletidamente, absurdamente a vida"; "a minha assombrosa, quase absurda, o Paulo Prado já chamou de 'monstruosa', sensualidade. [...] Uma espécie de pansensualidade"842. Bandeira, em uma carta de 1928, ao comentar um artigo de Mário, observou essa tendência do amigo para o excessivo (vimos na parte anterior deste trabalho, inclusive, que o exagero é um elemento essencial da própria linguagem do autor de Macunaíma): "Você quando se apaixona, de certa maneira se prejudica, perde o senso de equilíbrio, vai sempre além do que deve. Creio que a sua sensibilidade é apaixonada, de sorte que o que para os outros traz de bom o apaixonar-se, para você redunda sempre em excessos" ${ }^{\text {"43. }}$. Mário, por sua vez, escreveria em 1930 a Drummond: "Tudo pra mim são imediatamente paixões"844; assim como diria, dez anos depois, a Oneyda Alvarenga: "Eu me apaixono extraordinariamente, sensualmente, por tudo quanto passa por minha vida" ${ }^{945}$.

Viver, nesse quadro, é viver "de modo superlativo" - ou melhor, in extremis, nos instantes em que a vida, em seu paroxismo, em sua intensificação máxima, confina com a morte. Não por acaso, em carta a Drummond, Mário na esfera da religião situa esse modo de viver; o lado profano do escritor - e de sua obra - consuma-se no sagrado: “Tudo está em gostar da vida e saber vivê-la. Só tem um jeito feliz de viver a vida: é ter espírito religioso. Explico melhor: não se trata de ter espírito católico ou budista, tratase de ter espírito religioso pra com a vida, isto é viver com religião a vida". Adiante,

\footnotetext{
840 Jeanmaire, Henri. Dionysos: histoire du culte de Bacchus, op. cit., pp. 22, 38, 248-250.

841 Nietzsche, Friedrich. A visão dionisíaca do mundo, São Paulo: Martins Fontes, 2005, p. 13, grifos meus.

842 Andrade, Mário de. Danças dramáticas do Brasil, op. cit., p. 69; Idem. Mário de Andrade-Oneyda Alvarenga: cartas, op. cit., p. 272.

${ }^{843}$ Idem. Correspondência - Mário de Andrade \& Manuel Bandeira, op. cit., p. 375.

${ }^{844}$ Idem. A lição do amigo, op. cit., p. 163.

${ }^{845}$ Idem. Mário de Andrade-Oneyda Alvarenga: cartas, op. cit., p. 273.
} 
Mário especifica sua proposição, afirmando que esse "espírito religioso" se encontra nas classes populares, na "gente chamada baixa e ignorante": "É com essa gente que se aprende a sentir e não com a inteligência e a erudição livresca. Eles é que conservam o espírito religioso da vida e fazem tudo sublimemente num ritual esclarecido de religião". O modelo desse modo "feliz" de viver, conclui o escritor, é uma espécie de transe dionisíaco em sua forma conhecida, a dança: "Eu conto no meu 'Carnaval carioca' um fato a que assisti em plena Avenida Rio Branco. Uns negros dançando o samba . Mas havia uma negra moça que dançava melhor que os outros. Os jeitos eram os mesmos, mesma habilidade, mesma sensualidade mas ela era melhor. Só porque os outros faziam aquilo um pouco decorado, maquinizado, olhando o povo em volta deles, um automóvel que passava. Ela, não. Dançava com religião. Não olhava pra lado nenhum. Vivia a dança. E era sublime. Este é um caso em que tenho pensado muitas vezes. Aquela negra me ensinou o que milhões, milhões é exagero, muitos livros não me ensinaram. Ela me ensinou a felicidade" ${ }^{\circ 46}$. O prazer de Mário, na vida e na obra, se realiza na forma paroxística do transe dionisíaco ${ }^{847}$.

Vimos que o transe, sacralização do indivíduo por meio de sua própria destruição, portanto passagem violenta do mesmo no absolutamente outro, é uma forma sacrificial; as convulsões da vítima que agoniza e do possuído que delira são fenômenos aparentados. Vimos ademais que, no dionisismo, as afinidades entre o transe e o sacrifício são ainda maiores, uma vez que Dioniso encarna a própria figura do Estrangeiro, ou do Outro, e que o delírio se anima do vinho, metáfora do sangue da vítima expiatória $^{848}$. Nessa linha, vale lembrar que Nietzsche, o filósofo por excelência do dionisíaco, considera o rompimento do principium individuationis, portanto aniquilação do indivíduo, a própria essência do dionisíaco ${ }^{849}$. Salvo engano, embora Nietzsche denuncie em sua obra a ideologia do sacrifício, em especial na sua versão

\footnotetext{
${ }^{846}$ Idem. A lição do amigo, op. cit., pp. 3-5.

${ }^{847} \mathrm{Na}$ primeira parte deste trabalho, vimos inclusive que o transe é o princípio supremo de criação poética de Mário de Andrade. Ver, supra, pp. 25-34.

${ }^{848}$ Ver, supra, pp. 191-194.

${ }^{849}$ Nietzsche, Friedrich. O nascimento da tragédia, São Paulo: Companhia das Letras, 1999.
} 
cristã, opondo-se radicalmente a ela, existe uma dimensão sacrificial nessa destruição do indivíduo que o dionisismo proporciona - não por acaso, o pensamento nietzscheano coloca o dionisíaco na origem do trágico. Este último, associado às imagens, que são apolíneas, compõe a tragédia. No esquema de Nietzsche, como se sabe, Dioniso opõe-se a Apolo, o deus solar da medida, dos limites e das distinções - em suma, o deus da individuação -, ao passo que no entusiasmo dionisíaco todas as separações - entre os homens, os deuses e a natureza, entre o presente e o passado etc. - desaparecem. Não é à toa que Mário, nosso poeta dionisíaco, recomenda a Manuel Bandeira, em carta de 1931, o "abandono da visão individualista, do Sol que separa as coisas": "Você tem de esquecer o Sol separador,/ A própria Lua de luar que marca as sombras;/ [...] Siga ceguinho m'ermão" 850 .

Uma das distinções mais importantes que o dionisíaco faz desaparecer, diz Nietzsche, é a diferença entre o prazer e a dor: "Somente a maravilhosa mistura e duplicidade dos afetos do entusiasta dionisíaco lembra - como um remédio lembra remédios letais -, aquele fenômeno, segundo o qual os sofrimentos despertam prazer e o júbilo arranca do coração sonidos dolorosos. Da mais elevada alegria soa o grito de horror ou o lamento anelante por uma perda irreparável’’851. No entusiasmo dionisíaco, portanto, o prazer e a dor não apenas se unem como passam um no outro. Considerando-se que a passagem do mesmo no seu oposto constitui, como temos visto com Pasta, uma estrutura que radica no núcleo mesmo da formação histórico-social brasileira, começamos a compreender que o transe dionisíaco, na obra de Mário de Andrade, é uma forma paroxística de apreensão da matéria nacional em suas contradições mais profundas e insolúveis.

O transe dionisíaco, de fato, consiste em um estado de paroxismo. São os extremos do prazer e do desprazer, diz Nietzsche, que coincidem no dionisismo, de modo que a expressão do entusiasta dionisíaco é o grito que integra o horror e o júbilo $^{852}$. Na obra de Mário, vimos que esse grito de dor superlativa e de máximo prazer

\footnotetext{
${ }^{850}$ Andrade, Mário de. Correspondência-Mário de Andrade \& Manuel Bandeira, op. cit., p. 482.

${ }^{851}$ Nietzsche, Friedrich. O nascimento da tragédia, op. cit., p. 34.

${ }^{852}$ Idem. A visão dionisíaca do mundo, op. cit., p. 37.
} 
é um dos princípios de composição de Paulicéia desvairada ${ }^{853}$. Todavia, no grito de Paulicéia predomina o modelo expressionista, ou seja, embora assinale a passagem sacrificial do sujeito na cidade de São Paulo, ele é sobretudo o grito do indivíduo: “é um grito dum homem só”, diz Mário sobre Paulicéia, em carta de 1926 a Drummond ${ }^{854}$. A idéia da festa, assim como a forma da dança, essenciais para caracterizar-se o dionisíaco, apenas se esboça no livro, na imagem da sarabanda das doenças paulistanas, em "Paisagem n ${ }^{\circ}$ ".

Nesse sentido, é no poema "O Carro da Miséria" que o teor dionisíaco do grito marioandradino ganha forma. Escrito "em dois momentos de estouro doido" - 1930 e 1932 -, em estado de "bebedeira”, segundo o próprio Mário, "O Carro da Miséria” é um poema carnavalesco, no qual dança a sociedade brasileira - em sua configuração paulista - dos anos de 1930, sob o signo das desilusões causadas pelas revoluções de 1930 e de 1932, revoluções que Mário acompanhou com esperança e desespero ${ }^{855}$ :

"Maxixa agora samba o coco

E te enlambuza na miséria nacionar.

$[\ldots]$

Você fede a veterano

Da rabolução de julho

Tava danado

Com a sonhança desses pestes

Que juguei no Júlio Prestes

Mas quem deu foi o Getúlio.

Meu baralho dois ouros

\footnotetext{
${ }^{853}$ Ver, supra, pp. 207.

854 Andrade, Mário de. A lição do amigo, op. cit., p. 96.

855 A história da gênese de "O Carro da Miséria" é contada por Mário de Andrade em carta de 1944 a Carlos Lacerda, a quem o poema é dedicado. Andrade, Mário de. 71 cartas de Mário de Andrade, op. cit., pp. 84-91.
} 
Eu não quero mais jogar.

\section{$[\ldots]$}

Tanto heroísmo tanto estralo

Que arrisquei tudo em São Paulo

Mas quem deu foi a treição.

Meu baralho dois ouros

Eu não quero mais jogar.” 856

As várias classes e grupos sociais de São Paulo surgem no cortejo, compondo-se a imagem de uma verdadeira mixórdia histórico-social: os novos-ricos que pretendem ingressar na aristocracia paulista ("Mai' não me assustem/ Que num mês viro paulista/ Ganho bem suspendo a crista/ E tenho quatrocentos anos"); os banqueiros (Pica-Fumo Rompe-Rasga/ João Jaffet e mariposa/ Olê banqueiro da esquina/ Acende a vela da esposa"); os operários e os trabalhadores rurais ("São os moços negros não da África/ São os moços nugros lá das oficinas/ Fábricas e chavascais"); os industriais ("Larinhos crespinhos e matarazinhos"); os militares ("o coronel o ginaral o gafetão"); a gente do litoral e a do interior ("caipiras praieiros bicho-do-mato rendeiras").

Apresentando, dessa forma, o conjunto da sociedade em um momento histórico específico, o poema é atravessado por gritos contrários entre si: logo na abertura, um grito de júbilo, que faz esquecer a miséria da realidade ("Charangas na terra-roxa das estações um grito/ Um grito não um gruto/ Que me faz esquecer a miséria do mundo pão pão"); quase ao final, um grito de dor, que espera destruir o mundo injusto ("Um desejo de destruir tudo num grito/ Num grito não num gruto/ E dar um beijo em cada mão de quem trabalha..."). A duplicidade formada por esses gritos se concentra na imagem ambivalente dos gritos cegos, que se encontra no meio do poema: "Venham escutar $[\ldots]$ a tropilha em rancor cegar meus gritos". Segundo uma primeira leitura, a 
tropilha, um grupo de farristas do carnaval, "cega" os gritos de horror do eu-lírico, ou seja, o samba obnubila a visão da miséria social, fazendo com que os gritos passem do horror ao prazer. A tropilha, contudo, encontra-se "em rancor", de modo que o sentido da imagem pode ser o inverso: os gritos de alegria do eu-lírico são calados pelo cortejo da miséria - ou mesmo por uma tropa de soldados, uma vez que "tropilha" comporta esses dois significados, o festivo e o militar. No limite, pode-se dizer que o poema inteiro é a expressão de um grito dionisíaco ambivalente, que se converte em palavra dançada, oscilante, na palavra em que o trágico passa no cômico e vice-versa: "Chorar é bom, rir bim, raivar é bão pão pão".

$\mathrm{Na}$ base desse grito, está o desespero do eu-lírico em relação às possibilidades históricas de superação das contradições sociais. Não por acaso, o poema se encerra, depois de um apelo à revolução, com a imagem de uma espera de natureza messiânica: "Nasce o dia canta o galo/ O salvador não nasceu/ [...] Acorda acorda Tia Miséria/ Vem nascendo um dia enorme/ Mas pouco se vê porém// Ôi Tia Misemiséria/ Tens de parir o que eu espero/ Espero não! esperamos/ O plural é que eu venero".

Ao longo de todo este trabalho, vimos que o sacrifício, na obra de Mário, funciona como solução extrema desse "desespero histórico". Não por acaso, no "Carro da Miséria", além de entusiasta dionisíaco, o eu-lírico figura também como uma vítima sacrificial. Logo no início do poema, a imagem dionisíaca da anulação do indivíduo e a imagem sacrificial do corpo despedaçado se associam: "Não sou mais eu nunca fui eu decerto/ Aos pedaços me vim - eu caio! - aos pedaços disperso" ${ }^{\text {857 }}$. A certa altura, o paradigma do Cristo não deixa de surgir - "Tia Miséria talvez antes que o galo cante/ Me negarás três vezes Tia Miséria...” -, e reaparece a imagem da escrita de sangue, presente em Há uma gota de sangue em cada poema, como vimos no início deste trabalho. No núcleo da felicidade dionisíaca encontra-se o sofrimento do sacrifício:

857 Vale notar que, a rigor, segundo o eu-lírico, não se trata simplesmente de uma aniquilação do indivíduo, mas de um indivíduo que se despedaça antes de se integrar, que se arruína antes de se formar um movimento bastante brasileiro, ligado ao fato de que a ordem burguesa, à qual se vincula o regime da individuação, nunca chegou a se constituir plenamente no Brasil, combinando-se a formas sociais préburguesas que jamais desapareceram da vida social, e nas quais esse regime não tem vigência. 
"Mas eu mas eu rapazes

Canto com convicção.

Eu canto as viúvas canto os marmeleiros.

Canto o gosto do mel e da amplidão

Librar librar asas de ouro e granada

Sobre o Carro da Miséria

Mas si o carro está escarlate

Que parece um bonifrate

Isso é sangue era-não-era

Que só com a Vaca-Amarela

Parou o esguicho coagulou"

Por meio da forma popular, o poema diz as coisas mais terríveis em tom jocoso, configurando-se uma duplicidade expositiva bastante peculiar, que Mário encontrava na arte do povo e exploraria em muitos outros momentos de sua obra, como no "Côco do Major" ou na história da "serra do Rola-Moça", no "Noturno de Belo Horizonte", em que se narram de maneira "ingênua" tragédias medonhas. N'O banquete, uma das personagens chama a atenção para o horror que subjaz a muitas das produções populares, ligeiras à primeira vista: "Quando o povo canta 'Fui passar na ponte - A ponte tremeu - Água tem veneno - Quem bebeu morreu' a gente acha bobagem e conclui que as frases não tem (sic) ligação. Ou apenas acha graça sem se comover com tudo o que existe de profundo, de queixa, de fraqueza, de aviso sombrio nessa quadra"858. Na raiz mesma da alegria popular, Mário de Andrade encontrava, e procurava ressaltar em sua poesia, uma dor secular: "Ora hoje eu quero gritar de tal

\footnotetext{
${ }^{858}$ Andrade, Mário de. O banquete, op. cit., p. 91.
} 
forma que meu grito seja o de toda gente", escreve ele a Drummond ${ }^{859}$. O grito

dionisíaco de Mário é também o grito da revolta social ${ }^{860}$.

${ }^{859}$ Idem. A lição do amigo, op. cit., p. 96. Não obstante, a lírica de Mário raramente obtém uma síntese estável entre a expressão individual e as formas coletivas, síntese que a poesia de Manuel Bandeira costuma alcançar, conforme escreveu o próprio Mário de Andrade em 1931, em um balanço da produção poética de seu tempo. Na obra de Bandeira, o acordo entre o elemento subjetivo e o popular se realiza à medida que a paixão pessoal se recolhe, humilde, e assume a simplicidade característica das formas de expressão do povo. Na poesia de Mário, ao contrário, a voz individual tende a expandir-se de maneira desmedida e despótica, tornando-se coletiva no momento em que, alcançando abrangência máxima, não pode senão passar no seu outro, a totalidade da cultura. Por outro lado, enquanto na poesia de Bandeira a matéria popular é mediada pelo indivíduo, na lírica de Mário ela tende a passar no sujeito, anulando-o. Noutros termos, a incorporação das matrizes populares pela poesia marioandradina se consuma em uma espécie de curto-circuito entre o sujeito e a tradição. Esse regime, claro, não se aplica a toda a variada poesia Mário - em muitos dos poemas da Lira paulistana, por exemplo, uma síntese entre a voz individual e a voz coletiva parece ser obtida.

No "Carro da Miséria", por exemplo, a passagem da introdução meditativa, individual, em versos livres, para a segunda parte do poema, coletiva, em forma de coco, ocorre quando o eu-lírico se amplifica para abraçar nada menos que o todo, movimento que se reflete na linguagem, magnificada nas letras maiúsculas: "Aos pedaços me vim - eu caio! - aos pedaços disperso/ Projetado em vitrais nos joelhos nas caiçaras/ Nos Pireneus em pororoca prodigiosa/ Rompe a consciência nítida: EU TUDO AMO". Nesse momento de potenciação superlativa, o sujeito passa na tradição, anulando-se: "Ora vengan los zabumbas/ [...] Maxixa agora samba o coco/ E te enlambuza na miséria nacionar".

Segue-se, como se disse, um coco, no qual a presença da matéria popular não se restringe ao modelo rítmico e estrófico, mas invade o próprio campo da linguagem, como se o eu-lírico fosse possuído pela tradição coletiva; de certo modo, o poeta se torna um cantador nordestino: "E diz o prinspo/ Sangue-azul louro perneta/ Ontem me deu na veneta/ Fui na venda pra jogar"; "Diz o ariano/ Deixe de parte seu mano/ Você fede a veterano/ Da rabolução de julho". A "ocupação" dos versos pelo material coletivo se consuma no refrão do poema, que é a transcrição - um "plágio", diz Mário - de versos de um coco recolhido pelo escritor no Nordeste; a voz individual desaparece por completo: "Meu baralho dois ouros/ Eu não quero mais jogar/ Meu baralho dois ouros/ Eu não quero mais jogar"s.

Desse modo, o emprego das matrizes populares se realiza sob uma espécie de possessão do indivíduo pela coletividade, ao mesmo tempo em que essa possessão somente se dá quando o indivíduo expande-se ao máximo de suas potencialidades. Há algo de violento nessas passagens, ainda que elas se dêem com base no amor - mesmo porque o amor, em Mário, se realiza em grande medida sob a forma da luta de morte, conforme visto com José Antonio Pasta Júnior. Não por acaso, o eu-lírico ora recusa o carnaval e o elemento popular ("Mas não quero estes zabumbas!"), ora o deseja com entusiasmo ("Estes zabumbas que eu quero!"), oscilação que corresponde, no poema, à alternância de desengano e esperança diante das possibilidades de superação das contradições histórico-sociais.

"O Carro da Miséria" forma, portanto, um conjunto bastante fraturado, alternando partes em versos medidos, de matriz popular, e partes em versos livres, em que a marca individual é muito forte, sem que essa alternância se configure com harmonia. Isso não significa que o poema seja menos bom do que, por exemplo, os poemas em que Bandeira logra uma síntese entre as vozes do indivíduo e da coletividade; de certa forma, essa síntese supõe uma dose de ilusão, uma vez que ela não se encontrava no horizonte histórico. Nesse sentido, em sua negatividade, em sua ruína, em seu mal-acabamento, em sua violência, a poesia de Mário reproduz de forma dramática as fraturas que cindiam a sociedade brasileira e criavam um abismo entre os intelectuais e as classes populares.

Sobre esses aspectos da poesia de Bandeira, ver Arrigucci Jr., Davi. Humildade, paixão e morte: a poesia de Manuel Bandeira, op. cit., 45-87, 165-232; Andrade, Mário de. "A Poesia em 1930", in Aspectos da literatura brasileira, op. cit., p. 40.

${ }^{860}$ Com efeito, vimos que, no Café, a revolução se desencadeia sobretudo sob a forma do dionisismo, do poder contagioso do transe dionisíaco, transe que a própria obra procura provocar no espectador, por meio do que Mário chamava de "poder socializante do ritmo" - ao contrário da obra Brecht, por exemplo, que se organiza para, entre outras coisas, produzir o distanciamento, ou seja, quebrar a identificação do público com o drama, de modo a incitar o espectador a uma "tomada de posição refletida" sobre as questões envolvidas na peça, como disse Benjamin no ensaio "Que é o teatro épico? Um estudo sobre Brecht", in Obras escolhidas, volume I-Magia e técnica, arte e política, op. cit., pp. 78-107. Sobre o caráter contagioso, "epidêmico", do transe dionisíaco, ver Detienne, Marcel. Dionysos à ciel ouvert, op. cit., pp. 11-43. 
Com efeito, Mário encontrava em si mesmo a duplicidade que identificava nas formas populares; para ele, o sofrimento é uma felicidade e a felicidade, um sofrimento. Ao longo de toda a sua correspondência, Mário repete frequentemente a idéia contida nos versos seguintes de Losango cáqui: "É tão gostoso gostar da vida!...// A própria dor é uma felicidade!" ${ }^{861}$. Logo em 1923, portanto no seguinte ao da composição dos poemas do livro, Mário afirma a Bandeira: "Não só me penso, mas me sinto um homem muito feliz: porque para mim a dor cabe perfeitamente dentro do sentimento de felicidade" $" 862$. No mesmo sentido, mais de vinte anos depois, em carta de 1944, ele escreve a Newton Freitas: "Lhe mando o meu retrato que mais gosto, mas exijo troca. Gosto mais porque marca no meu rosto os caminhos do sofrimento, você repare, cara vincada, não de rugas ainda, mas de caminhos, de ruas, praças, como uma cidade. Às vezes, quando espio esse retrato, eu me perdoo e até me vem um vago assomo de chorar. De dó. Porque ele denuncia todo o sofrimento dum homem feliz" ${ }^{863}$. Segundo Mário, essa conjugação, em sua vida, de sofrimento e felicidade se reflete, naturalmente, em sua poesia: em carta de 1926 a Drummond, ele observa a "felicidade franca que ressumbra até dos meus poemas dolorosos"864. A explicação desse aparente paradoxo encontra-se na própria carta a Bandeira citada acima, o que revela que Mário sabia, desde o início, o que queria dizer: "Felicidade não implica antagonismo com dor. [...] O oposto de felicidade é ateísmo" ${ }^{\text {(65 }}$. Noutros termos, a felicidade, como vimos, está em "viver com religião", portanto no entusiasmo, no transe, no êxtase: "Esta permanência de tortura e de abatimentos até morais de toda casta diante da injustiça de compreensão dos meus próprios companheiros (e dos outros não posso exigir nada, reconheço) palavra que era pra abater um homem. No entanto este entusiasmo, esta paixão, esta claridade em que vivo com minha consciência este sobretudo este (sic) prazer com que mesmo torturado por dentro estou gozando, ou isto é felicidade ou então

\footnotetext{
${ }^{861}$ Andrade, Mário de. Losango cáqui, XVII, in Poesias completas, op. cit., p. 136.

862 Idem. Correspondência-Mário de Andrade \& Manuel Bandeira, op. cit., p. 99.

${ }^{863}$ Idem. A lição do amigo, op. cit., p. 39.

${ }^{864}$ Idem. Ibidem, p. 75.

${ }^{865}$ Idem. Correspondência - Mário de Andrade \& Manuel Bandeira, op. cit., p. 100.
} 
que coisa é!”; "É possível que eu tenha dado a mim mesmo um conceito muito especial de felicidade. [...] Esse conceito vive e age dentro de mim [...], e principalmente me faz gozar seriamente mas com sensualidade inenarrável os meus mais rápidos momentos até de amargura!" 866 . O próprio momento em que se revela esse "conceito muito especial de felicidade", é descrito por Mário como um êxtase - em seu paradoxo, que lhe confere certo mistério, essa verdade não poderia aparecer senão como revelação: assim, Mário recorda a Manuel Bandeira, em carta de 1929, "o dia em que fiquei cego de tanta clareza minha, exclamando que a própria dor é uma felicidade"867.

Por outro lado, considerando-se que a felicidade é o transe, ela é também sofrimento, uma vez que o transe, conforme dito, é uma estrutura sacrificial, um traspasse, em que o sujeito, no instante em que se eleva a um estado de exaltação máxima, passa no seu outro, ao passo que o outro passa no sujeito. Não por acaso, em carta de 1929 a Alceu Amoroso Lima, a felicidade é vinculada por Mário de Andrade ao trágico: "Porque feliz, isso eu sou. [...] É que me fiz prender por um entusiasmo de corpo e alma pelos movimentos da vida e os vivo com uma intensidade pasmosa. [...] Sentimento trágico da vida? Sim: sentimento trágico da vida. [...] Tragédia é dialogação do ser humano (no sentido mais completo) com o que não é ele, com o não-eu. Ora você procure com lanterna de hoje em toda a obra minha [...]. Reajo sempre. Há sempre dialogação. E por vezes essa dialogação é dolorosíssima"868. Creio haver elementos suficientes nessa passagem para compreender-se a "dialogação" a que o escritor se refere como uma identificação com o não-eu, assim como para entender o "reagir" ao outro como um comover-se com o outro. De fato, as expressões que Mário emprega para caracterizar sua relação com a vida - "entusiasmo de corpo e alma pela vida", "viver com intensidade pasmosa" -parecem referir-se a uma possessão do indivíduo pelo não-eu. Sendo assim, a relação com o outro não se configura sob a forma da alteridade pressuposta no diálogo; antes, o "diálogo" com o outro, ou a "reação" ao outro, a que Mário se refere, assume uma forma que lembra a curiosa alteridade à

\footnotetext{
${ }^{866}$ Idem. Ibidem, p. 378, 420.

${ }^{867}$ Idem. Ibidem, pp. 420-421, grifo meu.

${ }^{868}$ Idem. 71 cartas de Mário de Andrade, op. cit., p. 18.
} 
brasileira definida por Oswald de Andrade em um ensaio de 1950, em que o autor de Poesia Pau-Brasil examina o conceito de "homem cordial", elaborado por Sérgio Buarque de Holanda, como se sabe, como uma espécie de "tipo social" característico do país: "Pode-se chamar de alteridade ao sentimento do outro, isto é, de ver-se o outro em si, de constatar-se em si o desastre, a mortificação ou a alegria do outro. Passa a ser assim esse termo o oposto do que significa no vocabulário existencial de Charles Baudelaire - isto é, o sentimento de ser outro, diferente, isolado e contrário" ${ }^{869}$. Mais precisamente, a possessão, em Mário, assume a forma da formação supressiva, que examinamos anteriormente, uma vez que a passagem do outro no eu corresponde também, no caso marioandradino, à passagem despótica do eu no outro.

Com efeito, ao afirmar sua felicidade "trágica", Mário sublinha que ele se fez prender à vida com um "entusiasmo de corpo e alma"; ou seja, a possessão origina-se de uma decisão do sujeito, de uma afirmação do indivíduo. Dessa forma, ela não parte do outro que "desce" no sujeito, antes é o próprio sujeito que decide ser o outro. A possessão se consuma a partir de um movimento de constituição do próprio sujeito que, nesse caso, forma-se por meio de sua própria supressão, ao possuir o outro e ser possuído por ele. Vale lembrar que, segundo Mário, seu “entusiasmo pelos movimentos da vida", seu interesse por todas as coisas, sua "incapacidade de indiferença" em relação aos homens e ao mundo, em que se fundamenta a sua felicidade "trágica", vincula-se ao "amor pelo todo" que ele com frequência dizia sentir: "Sou incapaz de ser indiferente, incapaz de desamá-los e continuo amando-os com o mesmo amor”, escreve Mário, por exemplo, sobre modernistas que o haviam decepcionado ${ }^{870}$. Ora, vimos que o amor, na obra de Mário, assume sobretudo a forma da formação supressiva; amar significa sobretudo ser o outro em um abraço de morte. Em suma, a felicidade "trágica" de Mário consiste em ser o não-eu, de modo que ela pressupõe, como o transe dionisíaco, a ruptura do princípio de individuação: "Eu sou tão não-eu, tão os outros [...] a minha felicidade é feita de poucadinhos de felicidade alheia. [...] Felicidade na vida me parece

\footnotetext{
869 Andrade, Oswald de. "Um aspecto antropofágico da cultura brasileira: o homem cordial", in Obras completas, VI-Do pau-brasil à antropofagia e às utopias, op. cit., p. 141.

${ }^{870}$ Idem. Correspondência - Mário de Andrade \& Manuel Bandeira, op. cit., p. 246.
} 
que depende principalmente de duas coisas: a gente ser humano em vez de indivíduo e ter um conhecimento franco da vida" $" 871$.

Nesse contexto, a felicidade não se confunde com a alegria, que era considerada por Mário um sentimento individualista, que supõe a indiferença em relação ao outro, conforme ele escreve em 1927 a Alceu Amoroso Lima: "Você não encontra um só livro meu que seja deveras alegre. É certo que muitas vezes, talvez a maioria, sou loquaz, tagarela, pândego, gargalhante até. Mas onde você encontra alegria indiferente, individualista nisso?" 872 . Ser feliz é sofrer o não-eu, assumir o outro no próprio corpo e, por sua vez, passar no outro - "poesia é sofrimento mesmo", diz Mário, em 1930, ao mesmo Alceu ${ }^{873}$. Com efeito, essa passagem recíproca, esses traspasses, pressupõem sofrimento, uma vez que implicam a anulação do indivíduo 874 : "A correspondência [amorosa], pra quem está um pouco acima do ramerrão do mundo, é tão dolorosa como a não correspondência" 875 . O prazer consuma-se como um instante de dor: "Não só me penso, mas me sinto um homem feliz. [...] Eu estuo e quebro-me de amor por todos os homens"; "Eu me sacrifiquei inteiramente e quando eu penso em mim nas horas de consciência, eu mal posso respirar, quase gemo na pletora da minha felicidade" ${ }^{\prime 276}$. O prazer, portanto, é intenso ao ponto de fazer sofrer: "A oferta dos seus versos nem sei se é recompensa: me comoveu até a ardência profunda e me fez feliz"; "Que comoção 'horrível' você me deu com o seu artigo sobre mim!" ${ }^{877}$. Em suma, a felicidade, na vida e na obra de Mário, se encontra no estado do gozo, ou seja, no instante em que o prazer coincide com a morte: "sou dolorosamente feliz", disse Mário a Bandeira, em $1931^{878}$.

\footnotetext{
${ }^{871}$ Idem. A lição do amigo, op. cit., p. 40, grifo meu.

${ }^{872}$ Idem. 71 cartas de Mário de Andrade, op. cit., p. 17.

873 Idem. Mário de Andrade escreve cartas a Alceu, Meyer e outros, in op. cit., p. 16.

${ }^{874}$ Em uma carta aberta pra João Alphonsus de Guimaraens, de 1926, Mário diz querer “viver alastrado, amorosamente nulificado, unanimizado". Idem. A lição do amigo, op. cit., p. 299, grifo meu.

875 Idem. Correspondência - Mário de Andrade \& Manuel Bandeira, op. cit., p. 495.

${ }^{876}$ Idem. Ibidem, p. 90. Idem. A lição do amigo, op. cit., p. 6.

${ }^{877}$ Idem. A lição do amigo, op. cit., pp. 79, 214.

${ }^{878}$ Idem. Correspondência - Mário de Andrade \& Manuel Bandeira, op. cit., p. 495.
} 
Conforme dito, o transe dionisíaco, como estrutura sacrificial, constitui a forma por excelência do gozo na obra de Mário de Andrade, em especial na poesia. Sendo assim, de acordo com o próprio escritor, o dionisismo é um dos aspectos essenciais da lírica de Mário. Ao comentar os versos do "Carro da Miséria", em carta de 1944, Mário confirma uma importante observação feita por Roger Bastide, que será estudada adiante: "Por que 'zabumba'? A explicação é facílima em mim. É a constância coreográfico-dionisíaca que atravessa toda a minha poesia, e pra qual o Roger Bastide chamou a atenção. Em quase todos os grandes momentos extasiantes, na dor ou na alegria, eu "me dissolvo em dança" ${ }^{\text {"879 }}$. O dionisismo de que se encontra na obra de Mário, portanto, pode prender-se tanto ao prazer quanto ao sofrimento; nele pode expressar-se tanto o júbilo quanto o padecer. Em verdade, contudo, pode-se dizer que ele é sempre, em alguma medida, uma experiência dolorosa, como Mário sugere na seguinte passagem de uma carta a Tristão de Ataíde: "Está certo que você encontre um certo e franco dionisismo na minha obra, isto é, não uma vontade de gozar a vida, porém o gozo da vida, mas justamente no meu livro que você gostou menos, no Losángo cáqui, eu tenho um refrão muito digno de se matutar um pouco sobre ele: 'A própria dor é uma felicidade" $" 880$. Na poesia de Mário, o dionisismo, como de regra, como vimos com Nietzsche, opera as passagens do júbilo no sofrimento e do sofrimento no júbilo, as quais, no fundo, são uma das formas da passagem do mesmo no outro que o transe realiza em todos os níveis - passagem que constitui, conforme vimos com Pasta, o núcleo mesmo das constituições paradoxais do sujeito, da forma e da história na formação histórico-social brasileira.

O dionisismo, como se sabe, é inseparável da dança, que é a sua forma por excelência ${ }^{881}$. Na dança, assim como no transe, o mesmo é o outro e o outro é o mesmo. A mimesis, por meio dela, pretende ir além de si mesma e tornar-se identificação ou

\footnotetext{
${ }^{879}$ Idem. 71 cartas de Mário de Andrade, op. cit., p. 89.

${ }^{880}$ Idem. Ibidem, p. 17.

881 "Quanto às Dionisíacas e às Bacanais, elas não eram outra coisa senão danças, entre as quais as três principais eram o cordax [dançado nas comédias], a sikinnis [dança dos sátiros] e a emélia [dançada nas tragédias]", informa o importante diálogo de Luciano de Samósata sobre a dança. Samosate, Lucien de. Éloge de la danse, Paris: Arléa, 2007, p. 15-16.
} 
metamorfose: “A dança é uma ciência da imitação", escreveu Luciano de Samósata, notando contudo que, nela, algo da ordem do maravilhoso deve acontecer: "Proteu não era outra coisa senão um dançarino, capaz de assumir todas as formas, de imitar à vontade, por meio da vivacidade de seus movimentos, a fluidez da água ou o ardor das chamas, a ferocidade do leão, a agressividade da pantera ou os movimentos de uma árvore - e muitas outras coisas ainda. Mas com sua propensão para o maravilhoso, a lenda termina por contar que Proteu se tornava aquilo que ele imitava. Pode-se dizer o mesmo a respeito dos dançarinos, que vemos, por sua vez, mudar de forma e imitar o próprio Proteu. [...] O dançarino deve aderir às personagens representadas e não formar senão $u m$ com aquela que ele imita" ${ }^{982}$. Não por acaso, a dança sempre esteve ligada aos ritos mágico-religiosos nos quais a distância entre os homens e os deuses é suprimida; mais do que isso, explica Rouget, "a dança é a principal - e frequentemente a única expressão da possessão do indivíduo pela divindade", uma vez que ela assinala o grau máximo da passagem do deus no homem, o momento em que a identificação propriamente se consuma, ou seja, quando esta se dá no plano do corpo ${ }^{883}$.

Com efeito, a passagem da mimesis para a possessão, conforme expõe Roger Bastide em seu estudo sobre o camdomblé da Bahia, se realiza por meio da dança; noutras palavras, os deuses descem aos homens quando o chamado assume a forma da dança: "Os cânticos, todavia, não são apenas cantados, são também 'dançados', pois constituem a evocação de certos episódios da história dos deuses, ou seja, são fragmentos de mitos, e o mito deve ser representado ao mesmo tempo que falado para adquirir todo o poder evocador. O gesto juntando-se à palavra, a força da imitação mimética auxiliando o encantamento da palavra, os orixás não tardam a montar em seus cavalos à medida que vão sendo chamados"884. O outro dança no corpo do dançarino, que por sua vez vem a ser sendo outro, de modo que a dança figura como "a elocução do corpo divinamente alienado, $[\ldots]$ do corpo que significa o desejo de reunião com o

\footnotetext{
${ }^{882}$ Idem. Ibidem, pp. 14-34.

${ }^{883}$ Rouget, Gilbert. La musique et la transe, op. cit., p. 559.

${ }^{884}$ Bastide, Roger. Le candomblé de Bahia: rite Nagô, op. cit., pp. 49-50.
} 
Outro absoluto" 885 . Nesse sentido, "a dança é um gesto religioso", mesmo fora do contexto das religiões ${ }^{886}$; de acordo com uma formulação lapidar, a dança é a paixão de ser um outro: "O gozo da dança advém da identificação com o Outro celebrado. [...] Eu vou dançar, ou seja, devo preparar-me para sofrer, é excitante"\$87.

A relação privilegiada que a dança possui com a religião, como vimos acima, foi notada por Mário de Andrade. Conforme ele escreveu a Drummond, é a imagem de uma "negra moça" dançando o samba no carnaval carioca que lhe revela o que é "viver com religião". Vale a pena citar novamente a passagem: "os outros faziam aquilo um pouco decorado, maquinizado, olhando o povo em volta deles, um automóvel que passava. Ela, não. Dançava com religião. Não olhava pra lado nenhum. Vivia a dança" ${ }^{\circ 88}$. A dança aparece a Mário como a imagem de uma vivência absoluta, fechada sobre si mesma, bastando-se a si mesma em sua plenitude, portanto da vivência em que a mulher e os "deuses" encontram-se intensamente unidos. Assim, no poema em que Mário registra a cena "sublime", "Carnaval carioca", quando a dança profana acaba, a negra "termina se benzendo religiosa talqualmente num ritual"889. Essa "absolutização" que se consuma na dança foi também percebida por Valéry, que tinha como modelo uma dança muito diferente do samba, o ballet, em que a dançarina aparece ao poeta francês como uma totalidade auto-sustida, assim como os mitos: "O corpo que dança parece ignorar o que está à sua volta. [...] A bailarina está em outro mundo, [...] onde não há finalidade exterior aos atos" e "os movimentos têm em si mesmos seu fim"; "toda, ela se torna

\footnotetext{
${ }^{885}$ Legendre, Pierre. La passion d'être un autre: étude pour la danse, Paris: Seuil, 2000, pp. 198, 106.

${ }^{886}$ Idem. Ibidem, p. 29.

${ }^{887}$ Idem. Ibidem, p. 179, 75.

${ }^{888}$ Andrade, Mário de. A lição do amigo, op. cit., p. 5. Na mesma linha, ao narrar a sessão de catimbó de que participou em Natal, em 1928, para "fechar" seu próprio corpo, Mário assinala a diferença entre a possessão sincera e a possessão representada: “Os mestres vinham e iam-se embora, não querendo fechar o meu corpo impuríssimo. Acredito que o João era sincero. Manuel não, um farsante de marca maior, charlatão cabotino pararaca - os Mestres que entraram no corpo dele foram mal representados, procuravam jeito pra cair". Idem. O turista aprendiz, op. cit., p. 226.
}

${ }^{889}$ Idem. "Carnaval carioca” [1923], in Clã do Jabuti, in Poesias completas, op. cit., p. 167. 
dança, e toda se consagra ao movimento total!"890. Para o discípulo de Mallarmé, a dança constitui uma espécie de ação estética pura - portanto afastada da vida prática, em que as ações são úteis, isto é, dirigidas para a consecução de objetivos exteriores; a bailarina encontra-se "fora das coisas", ela se desliga ou se liberta, e não retorna senão para fugir mais, ainda, do plano sobre o qual caminha a vida comum: a terra, o solo, o "lugar sólido" 891 . Nesse sentido, a dança opera uma passagem para a idealidade: "assim como a chama loucamente canta entre a matéria e o éter, - e da matéria ao éter furiosamente se precipita, - a grande Dança, ó meus amigos, não é ela mesma esta libertação do nosso corpo inteiro, [...] embriagado da negação da nula realidade?"892. A dança, em que se opera a passagem do mesmo no outro, é também uma forma de passagem do ser no não-ser.

Na seção final dos "Poemas da amiga" [1920-30], de Mário de Andrade, o eulírico descreve, justamente, o momento em que, pousando a cabeça nos joelhos da “amiga", liberta-se do próprio corpo sob o signo da dança:

"Minha cabeça pousa nos seus joelhos,

Vem o entre-sono, e é milagroso!

A vida se conserva em mim doada pelos seus joelhos,

E sou duma inimaginável liberdade!

Ôh espíritos do ar que os homens adivinham,

Dizei-me o que se evola do meu corpo!

Essa outra coisa vaporosa e brancacenta

Que não é fumo, nem echarpe,

Não tem forma porém não se desmancha

\footnotetext{
890 Valery, Paul. "Philosophie de la danse" [1936], in Euvres I, Variété, " Théorie politique et esthétique », Paris: Gallimard, Bibliothèque de la Pléiade, 1957, p. 1399. Idem. Degas Danse Dessin, Paris: Gallimard, 2008, p. 28. Idem. "L'Âme et la danse", in Eupalinos/L'Áme et la danse/Dialogue de l'arbre, Paris: Gallimard, 2008, p. 126.

${ }^{891}$ Idem. "Philosophie de la danse", in op. cit., p. 1399.

${ }^{892}$ Idem. "L’Âme et la danse", in op. cit., p. 143.
} 
E baila no ar...

Todos os adeuses, todos os espelhos e girândolas

Voltijam no espaço que se enche e esvazia

Num tremor ávido a esfolhar-se em pregas sem dureza...

Abre a rosa oculta em sinais,

Manhãs em vésperas de ser

Pireneus sem desejo, enquanto à espreita,

Os objetos em torno me invejam

Buscando me prender na miséria da imagem...

Ôh espíritos do ar, dizei-me a rosa incomparável

Que se evola reagindo em baile no ar!

Baile! Baile de mim no entre-sono!

Não é uma alma, não é um espírito do ar, não é nada!

É outra coisa que baila, que baila,

Livre de mim! gratuita enfim! fútil de eternidade!

Ôh, brinca, brinca, minha melodia!

Sabiá da mata que canta a mei-dia!

Olha o coco, Sinhá!” 893

A passagem para um outro mundo ("e é milagroso!"), a libertação de si mesmo do próprio corpo (“E sou duma inimaginável liberdade! [...] Dizei-me o que se evola do meu corpo!"), a distância em relação ao mundo das coisas (“Os objetos em torno me invejam") e a ausência de finalidade exterior do movimento ("gratuita enfim! fútil de eternidade!") são temas centrais da reflexão de Valéry sobre a dança, como vimos, que se encontram no poema de Mário. Além disso, também para o poeta francês a dança se

893 Andrade, Mário de. "Poemas da amiga", XII, in Remate de males, in Poesias completas, op.cit., pp. 278-279. 
produz em estado de "entre-sono" e engendra algo como uma forma inapreensível ("Não tem forma porém não se desmancha/ E baila no ar..."), ou seja, a dança opera no limite entre a ausência e a presença: "Ela [a bailarina] celebra todos os mistérios da ausência e da presença!" 894 . Nessa linha, em seu ensaio sobre Degas, Valéry evoca o mestre Mallarmé, cuja poesia mesma celebra a passagem da presença na ausência, e que teria feito a observação mais verdadeira sobre a dança: "Mallarmé diz que a bailarina não é uma mulher que dança, pois ela não é uma mulher, e ela não dança"895. De acordo com esse ponto de vista, na dança consuma-se a negação de toda realidade. Ora, como o leitor terá pensado, poderá ser Mallarmé a referência principal do poema de Mário? Será possível ver, na "rosa oculta em sinais", que se abre em "pregas sem dureza", "que se evola reagindo em baile no ar", nessa "rosa incomparável", um reflexo da célebre flor mallarmeana: "Digo: uma flor! E, fora do esquecimento a que minha voz relega qualquer contorno, enquanto algo outro que os cálices sabidos, musicalmente se eleva, idéia mesma e suave, a ausente de todos os buquês" ${ }^{" 896 ?}$

Todavia, embora se desenvolva nessas zonas etéreas, o poema de Mário assume configurações próprias, muito distintas - e opostas em boa medida - das que são características do lirismo de Mallarmé ou de Valéry. Em vez da distância medida e da vibração resfriada da poesia dos dois poetas franceses, os versos marioandradinos exprimem um fervor, que culmina em transe dionisíaco, ou seja, em uma experiência de identificação. A esse movimento liga-se outro, decisivo para a compreensão do conjunto dos "Poemas da amiga": no apogeu de sua ascensão, o eu-lírico incorpora a própria terra, por meio da dança popular; no estado máximo de abstração, sua alma radica na realidade concreta. Nesse sentido, a dança de Mário é inversa à de Valéry, que foge do solo. O Brasil, sob a forma da tradição cultural do povo, passa no eu-lírico, quando este passa no não-ser, passagens que são realizadas por meio da dança. O poema se encerra no instante em que o sujeito vem a ser arruinando-se na totalidade, isto é, no instante da

\footnotetext{
894 Valéry, Paul. "L’Âme et la danse”, in op. cit., p. 133.

895 Idem. Degas Danse Dessin, op. cit., p. 33.

${ }^{896}$ Mallarmé, Stéphane. "Crise de vers”, in La musique et les lettres/Crise de vers, Paris: Ivrea, 1999, p. 35 .
} 
possessão: “Ôh, brinca, brinca, minha melodia!/ Sabiá da mata que canta a mei-dia!/ Olha o coco, Sinhá!”.

Não por acaso, as passagens representadas no poema se dão no "entre-sono", isto é, em uma espécie de trânsito da vida para a morte, ou melhor, no limite entre o ser e o não-ser. Nesse ponto, o trabalho de José Antonio Pasta permite, uma vez mais, compreender as estruturas poéticas marioandradinas e sua base histórico-social, agora por meio do conceito do regime do limite, formulado pelo crítico. De acordo com Pasta, o regime do limite pode ser compreendido a partir do regime da formação supressiva, no qual, como vimos, o mesmo se forma sendo o outro, portanto por meio de sua própria supressão. Sendo assim, ele se constitui no trânsito do mesmo no outro e do ser no não-ser, ou seja, ele vem a ser no instante em que deixa de ser. O limite é o instante que oscila indefinidamente entre o mesmo e o outro - "aquele instante infinitesimal e inapreensível em que o mesmo é o outro, o ser é o não ser"897.

Sendo assim, observa o crítico, a suspensão no limite entre o mesmo e o outro é "a verdade" do movimento da formação supressiva, e uma vez que esse movimento constitui uma estrutura histórica central no Brasil, grande parte dos heróis de nossas letras instala-se no limite, como o próprio Macunaíma, fixado em estrela, entre o ser e o não-ser ${ }^{898}$. "Essa fixação no entre dois, poder-se-ia denominá-la regime do limite", afirma Pasta, ressaltando em seguida a presença decisiva desse regime na cultura brasileira: "Talvez seja esse o regime dominante de nossas formações culturais. Claro que o limite não é pura e simplesmente, nesse caso, algo a ser respeitado. É algo feito para que se instale justamente sobre ele. E é assim que nosso filme mais mítico chamase justamente Limite, e é uma espécie de iconografia exaustiva, ainda que breve, de formas limítrofes; um dos mais comoventes, talvez, de nossos contos do século XX, chama-se 'A terceira margem do rio', aquela que está entre as duas coisas e ao mesmo tempo não existe; a história de amor mais sustentada de nossa literatura, aquela de Grande Sertão: Veredas, coloca o objeto do desejo numa mulher-homem ou num

\footnotetext{
${ }^{897}$ Pasta Júnior, José Antonio. “Tristes estrelas da Ursa-Macunaíma”, in op. cit., pp. 28-29.

${ }^{898}$ Idem. Ibidem, pp. 27-32.
} 
homem-mulher, como se queira. E é assim, igualmente, que as formas as mais enraizadas e mais difundidas de religião popular são entre nós, no fundo, formas espíritas, isto é, formas fundadas na idéia de metempsicose e tendo como manifestação principal o transe de possessão. Ora, na metempsicose, como no transe de possessão, sempre se é si-mesmo $e$ um outro, ao mesmo tempo. E assim por diante" 899 .

Também ao final dos "Poemas da amiga", como estamos vendo, configura-se uma situação limítrofe. No caso, essa fixação no limite vincula-se de maneira explícita à matéria brasileira. Com efeito, os poemas têm como tema central a impossibilidade de realizar-se, no Brasil, o amor entre o eu-lírico e a "amiga", amor que se mantém no limite entre a amizade e o erotismo: "Ôh, doce amiga, é certo que seríamos felizes/ Na ausência deste calamitoso Brasil!.... ${ }^{900}$. Vimos, na parte anterior deste trabalho, como as contradições históricas nacionais impedem a figuração da plenitude amorosa na poesia de Mário, ou melhor, permitem que essa plenitude seja obtida apenas na morte, portanto se desfazendo. Todavia, enquanto nos "Poemas da negra", no "Grã Cão do Outubro" ou no "Girassol da madrugada" o erotismo se consuma num abraço de morte, nos "Poemas da amiga", onde a mulher é mais amiga do que amante, nada ocorre - as ações se detêm no limite de si mesmas: "Si acaso a gente se beijasse uma vez só.../ Ontem você estava linda/ Que o meu corpo chegou.// Sei que era riacho e duas horas de sede,/ Me debrucei, não bebi"; "Te reclinaste sobre mim, como a verdade,/ Fui virar, fundeei o rosto no teu corpo.// Nos dominamos pondo tudo no lugar"; "Eu poderia dormir no teu regaço, ôh mana..."901.

Sem poder passar no seu outro, o eu-lírico abeira-se a todo instante do limite entre ele e a "amiga"; por fim, quando ele de fato se instala nesse limite, ao "pousar" nos joelhos da amiga, inicia-se uma outra passagem, que substitui a passagem no outro, detida a meio caminho - a passagem do ser no não-ser: no entre-sono, o eu-lírico se volatiliza em dança. Com efeito, de acordo com Pasta, a paralisação do movimento entre o mesmo e o outro, no instante em que o mesmo é o outro, enceta o movimento

\footnotetext{
${ }^{899}$ Idem. "Volubilidade e idéia fixa", in op. cit., p. 20.

900 Andrade, Mário de. "Poemas da amiga", in op. cit., p. 275.

${ }^{901}$ Idem. Ibidem, pp. 273-274, 278.
} 
entre o ser e o não-ser, uma vez que, se o mesmo é o outro, o ser é o não-ser; nesse sentido, afirma o crítico a respeito da "solução final" de Macunaíma, o herói de nossa gente: "Ele, que oscilava continuamente entre o mesmo e o outro, em sua forma finalmente fixada, fica basculando interminavelmente entre o ser e o não-ser. Esta última báscula já está, aliás, implicada na primeira, uma vez que a passagem contínua do mesmo no outro supõe a formação como supressão, ou seja, a oscilação entre ser e não-ser"902. Nos "Poemas da amiga", como vimos, a passagem do ser no não-ser assume a forma da dança e se consuma em uma espécie de transe, quando o eu-lírico é possuído pela tradição cultural brasileira e se converte em algo como um cantador popular - o Brasil vem a ser por meio da aniquilação do indivíduo na dança coletiva. $\mathrm{O}$ instante da passagem para o não-ser é o instante coréico: "Como és excelente na iminência!", exclama Erixímaco a uma bailarina, em um diálogo de Valéry, observando em seguida que, na dança, "o instante engendra a forma, e a forma faz ver o instante" 903 . A dança é uma espécie de limite em ato, a passagem em si mesma: "ela é o ato puro das metamorfoses", afirma Sócrates no mesmo diálogo 904.

A dança figura na obra poética de Mário de Andrade, justamente, como forma em que se realizam as passagens do mesmo no outro e do ser no não-ser, e desse modo, como forma de apreensão da paradoxal matéria histórica brasileira. Considerando-se que a lírica de Mário tem em seu núcleo o desejo de dar forma a essa matéria, compreende-se que a dança seja uma das constantes da poesia do escritor, conforme escreveu Roger Bastide em uma observação notável - cujo acerto o próprio Mário, como vimos acima, reconheceu: "Essa poesia não é uma simples emanação da alma, tende a se objetivar em gestos, em movimentos exteriores, em geometria colorida, tende para o ballet. [...] O ritmo desses poemas é um ritmo de dança. Por isso mesmo é bem brasileiro, porque é perfeitamente exato que o Brasil dança. [...] Na vida sentimental de Mário de Andrade, tanto seus momentos dionisíacos como seus momentos tenebrosos, se tornam samba, coco, inventam novos passos, e sua obra nos toma pelos músculos,

\footnotetext{
902 Pasta Júnior, José Antonio. “Tristes estrelas da Ursa-Macunaíma”, in op. cit., p. 27.

903 Valéry, Paul. "L'Âme et la danse”, in op. cit., pp. 125,145.

${ }^{904}$ Idem. Ibidem, p. 134.
} 
pelas vísceras para impor seu ritmo a nosso ser, para nos transformar, por sua vez, em ballet brasileiro" 905 . Segundo Bastide, portanto, a poesia de Mário de Andrade, nos seus momentos mais fortes, não assume a dança apenas como tema, mas também como forma literária, como se a assumisse em seu próprio "corpo"; mais do que referir-se à dança, a linguagem poética de Mário tende a dançar ela mesma. Sendo assim, prossegue o sociológo, o poema estabelece com o leitor uma relação especial: entra-lhe no corpo, toma-o pelo músculos, pelas vísceras, para impor-lhe o seu ritmo e convertêlo em dança também. Em outras palavras, o poema suprime a distância que o separa do leitor, ao mesmo tempo em que essa distância continua a existir, tendo em vista que o poema é literatura, não magia. Como obra literária, o poema põe a distância em relação ao leitor, mas ele a retira na medida em que assume a forma da dança. Assim, ele simultaneamente constitui e anula a distância estética; ou melhor, ele a constitui anulando-a.

Esse movimento, como vimos no início deste trabalho, foi identificado por José Antonio Pasta em romances decisivos da literatura brasileira, tendo sido interpretado pelo crítico como o desdobramento necessário do regime da formação supressiva no plano da relação entre a obra e o leitor: "Seja pelo ofuscamento, seja por uma espécie de terror, ou mesmo de charme encantatório, esses romances buscam, mais que fascinar o leitor, possuí-lo, se encarnar nele. [...] Num único e mesmo gesto de fala, o romance produz ou institui seu leitor e, ao mesmo tempo, o suprime ou o engole. A distância que produz o leitor enquanto outro, o texto ao mesmo tempo a põe e a retira" ${ }^{\prime 906}$. No caso dos poemas "dançantes" de Mário de Andrade, pode-se então dizer que eles, como poesia, formam o leitor, mas suprimindo-o, uma vez que são poemas coréicos.

A idéia da supressão da instância do "leitor" pelo ritmo da dança foi formulada pelo próprio Mário, ao descrever a experiência de assistir a um maracatu no carnaval do Recife, em 1928: “Já relatei noutro lugar a experiência curiosa que tive do efeito fisiológico do ritmo, num carnaval do Recife. Eu fora ver as danças iniciais do Maracatu

\footnotetext{
905 Bastide, Roger. Poetas do Brasil, São Paulo: Edusp/Duas Cidades, 1997, pp. 77-79.

906 Pasta Júnior, José Antonio. "Volubilidade e idéia fixa”, in op. cit., pp. 24-25. Ver, supra, pp. 6-7.
} 
do Lião Coroado. O pessoal, composto quase exclusivamente de negros e negras velhas, já estava na porta da rua dançando as cerimônias [...]. Interessadíssimo em minhas paixões folclóricas, eu me introduzira indiscretamente na roda, para ver se grafava a linha das melodias. Mas mesmo com o ouvido quase na boca dos cantadores, não escutava nada ante a barulheira rítmica. Desisti da melodia e me apliquei apenas a registrar os ritmos dos diversos instrumentos [...]. estava esquecido de mim, nesse trabalho de escrever, quando senti um mal-estar doloroso, a respiração opressa, o sangue batendo na cabeça como um martelo, e uma tontura tão forte que vacilei. Senti a respiração faltar, e cairia fatalmente se não me retirasse afobado daquele círculo de inferno. Fugi para longe, necessitado de reorganizar em sua pacífica fragilidade, meu pobre corpo de leitor infatigável. Mas os negros, as magras negras velhas lá ficavam com suas danças macias, lá ficariam horas, lá ficariam a noite inteira junto daquele estrondo, cada vez menos leitores, cada vez mais corpóreos..."907. O ritmo anula o leitor, pois anula o sujeito.

Não por acaso, diz Mário, o ritmo e a dança são elementos essenciais das músicas de feitiçaria no Brasil, que têm como finalidade, justamente, a supressão do indivíduo: “As músicas de feitiçaria afro-brasileiras não são apenas fortemente ritmadas, como possuem um decisivo caráter coreográfico. Isso já é uma das suas qualidades distintivas" $" 908$.

Esse poder do ritmo de aniquilar o sujeito vincula-se, segundo o escritor, às dinamogenias, que o ritmo é capaz de ativar como nenhum outro elemento artístico, de tal modo que ele suprime o indivíduo tomando-lhe posse do corpo e da psique: "Agindo com grande poder sobre a parte física do ser, ele provoca, mais que qualquer outro elemento estético, seja o som seja a cor, seja o volume, uma ativação forte do ser biológico total, não só físico, mas na complexidade maior do seu psiquismo também"909. As dinamogenias rítmicas são irresistíveis. Nessa linha, Mário descreve a impressão que lhe causa uma canção de Mussorgski, um artista com quem ele se

\footnotetext{
907 Andrade, Mário de. "Terapêutica musical”, in Namoros com a medicina, op. cit., pp. 18-19.

${ }^{908}$ Idem. Música de feitiçaria no Brasil, op. cit., p. 39.

${ }^{909}$ Idem. Pequena história da música, op. cit., p. 14.
} 
identificava em boa medida ${ }^{910}$. Mário não entende as frases da canção, em russo, mas o ritmo o possui: "Esse cântico me domina, me inutiliza em mim e não apenas eu me identifico com ele, como me surpreende uma comoção tão intensamente dinâmica, que logo à primeira frase eu sinto o meu gesto querendo se abrir no ar. E toda uma sugestão coreiforme, difícil de prender, vive em mim durante toda a obra" ${ }^{911}$. O ritmo figura nas reflexões de Mário, portanto, como uma força a que o sujeito não pode resistir, e que o aniquila - ou seja, como algo semelhante ao mana.

Mário, com efeito, chegou a identificar o sagrado, ou deus, ao ritmo - como vimos, no sacrifício, o sagrado "toma posse" da vítima: "Deus no Remate se torna 'alguma coisa mais desejada/ mais bem puxada, mais bem dançada', dança, isto é ritmo que unanimiza, que funde, que intercepta a vida do mundo 'pra que não basta noite de dança""912. Mário refere-se ao poema "Adivinha" [1928], que se encontra em "Marco de viração", e integra Remate de males:

"Mas o violão é mais imenso que as palavras

E não as compreende mais.

Que significa até a palavra 'Deus'?

... alguma coisa mais desejada...

Mais bem puxada, mais bem dançada,

Além do mundo e do pensamento...

Catira leve e jongo lento,

Pra que não basta noite de dança...

Êxtase de interminável festança,

Que a insuficiência do amor não abre

Na flor humana duma palavra...

\footnotetext{
${ }^{910}$ Alvarenga, Oneyda. "Sonora política”, in Mário de Andrade, um pouco, op. cit., p. 82.

911 Andrade, Mário de. “Ao Dnieper” [1943], in Coli, Jorge. Música final, op. cit., p. 86.

912 Idem. Mário de Andrade escreve cartas a Alceu, Meyer e outros, op. cit., p. 22.
} 
Ele ressoa no bojo do violão! no bordão! gentes, bem no bordão" 913

Para Mário de Andrade, portanto, o ritmo proporciona a compreensão daquilo que as palavras, em seus limites, não podem exprimir, em especial a idéia de deus, a qual, segundo o escritor, escapa à razão - de modo que os próprios versos acima não podem ser inteiramente compreendidos pelo intelecto, como diz Mário sobre eles, em carta de 1929 a Alceu Amoroso Lima: “Analisando essas palavras que eu não entendo intelectualmente bem, o que eu percebo é essa ânsia de Divindade que jamais me abandonou um segundo, o desprezo pela noção fatigante de Deus que a nossa inteligência (Inteligentzia?) precária pode ter"914. Um ano antes, em carta a Augusto Meyer, Mário desenvolvera o tema; o trecho é longo, mas vale a pena citar: "A inteligência é incapaz de acreditar integralmente em Deus, porque a inteligência é lógica e só tem como dados de raciocínio os que a ambiência em que ela se manifesta (o universo) the proporciona. Ora Deus não sendo uma abstração é ilógico pros dados concretos da inteligência. [...] Deus está absolutamente pra fora da inteligência porque ele não é inteligente. Isso simplesmente porque não pode existir um conceito de Deus, que seja relativo. Si a gente chega a um conceito verdadeiro de Deus, ao qual até no racionalismo politeísta grego Aristóteles, provavelmente Platão e outros chegaram, Deus tem de vir acompanhado de todos os requisitos fatais do conceito Dele, isto é, onisciente, todo poderoso etc. Sendo assim ele não pode possuir inteligência, que é coisa relativa. [...] Ora Ele não sendo um fenômeno objetivo, e sendo extrainteligência, si a inteligência chega a acreditar Nele é que ela deixou de ser lógica, isto é, deixou de ser inteligência ${ }^{915}$. É a que chamo de inteligência paralógica, ou milhor, compreensão paralógica. Constantemente utilizada pelo povo. Substitui inteligência por compreensão porque a compreensão é mais vasta que a inteligência. A compreensão muitas feitas é fisiológica, é sentimental. O fenômeno da compreensão musical por exemplo explica bem o que estou falando. A música que não tem dados intelectuais pra quem ignora

\footnotetext{
913 Idem. "Adivinha", in Remate de males, in Poesias completas, op. cit., p. 265.

${ }^{914}$ Idem. Mário de Andrade escreve cartas a Alceu, Meyer e outros, op. cit., p. 43. 
harmonia, acústica, etc. é perfeitamente compreendida por todos. É que nela que é absolutamente extraintelectual, a compreensão é em máxima parte fisiológica por meio do ritmo e do dinamismo sonoro [...]. Essa compreensão paralógica é a que me dá a certeza absoluta incondicional (e em nada cega) da existência de Deus"916. De acordo com o pensamento marioandradino, portanto, o ritmo propicia a compreensão do que está além da lógica.

Não é à toa que a dança, nos dois poemas de Mário em que ela figura propriamente como o elemento estruturador principal, "Carnaval carioca" e "Danças", funcione como forma de apreensão da matéria histórico-social brasileira: o Brasil, para Mário, é uma "mistura de mistérios"; em suas contradições e ambivalências, ele "arromba toda concepção que a gente faça dele"

Em "Carnaval carioca", de 1923, as relações entre a dança e o Brasil formam-se no contexto de uma festa que, por definição, promove em todos os seus níveis, como vimos acima, a passagem do mesmo no outro. O poema de Mário registra, com efeito, as principais inversões que participam da tradição do carnaval, ou seja, as inversões de sexo e de classe social, e a inversão entre o sagrado e o profano: “Cordões de machos mulherizados"; "Pierrots-fêmeas em calções mais estreitos que as pernas"; "O cabra enverga fraque de cetim verde no esqueleto"; "Oblatas de confetes no ar/ Incenso e mirra marca Rodo nacional"; "A baiana se foi na religião do Carnaval/ Como quem cumpre uma promessa./ Todos cumprem suas promessas de gozar"; "E gesticula fala canta. Prédicas do meu Senhor...”. No início do poema, depois de uma introdução em que o poeta hesita diante da festa, retido por sua "frieza de paulista", por seus "policiamentos interiores" e "preconceitos eruditos", uma imagem concentra as inversões de sexo e de classe:

"O indivíduo é caixeiro de armarinho na Gamboa.

916 Idem. Mário de Andrade escreve cartas a Alceu, Meyer e outros, op. cit., pp. 59-61.

917 Idem. "Flor nacional"[1930] e "Sinhô" [1929], in Táxi e crônicas no Diário Nacional, op. cit., pp. 154, 84. Nessa linha, vale lembrar que, segundo Mário de Andrade, o "herói de nossa gente", Macunaíma, é "uma contradição de si mesmo", de modo que sua lógica, disse Mário, "está em não ter lógica". Idem. Correspondência - Mário de Andrade \& Manuel Bandeira, op. cit., p. 368. 
Cama de ferro curta por demais,

Espelho mentiroso de mascate

E no cabide roupas lustrosas por demais...

Dança uma joça repinicada

De gestos pinchando ridículos no ar.

Corpo gordo que nem matrona

Rebolando embolado nas saias baianas" 918

As passagens do sagrado no profano e do profano no sagrado, por sua vez, consumam-se em uma estrofe que constitui, segundo o próprio Mário, "a imitação do salmo de Davi", portanto quando os próprios versos da festa profana-sagrada convertem-se em uma louvação de caráter bíblico, conversão em que Mário procura também conciliar a pândega com sua fé católica:

\section{“Aleluia!}

Louvemos o Criador com os sons dos saxofones arrastados,

Louvemo-Lo com os salpicos dos xilofones nítidos!

Louvemos o Senhor com os riscos dos recorrecos e os estouros do tantã,

Louvemo-Lo com a instrumentarada crespa do jazz-band!

Louvemo-Lo com os violões de cordas de tripa e as cordeonas imigrantes, Louvemo-Lo com as flautas dos choros mulatos e os cavaquinhos de serestas ambulantes!

Louvemos $\mathrm{O}$ que permanece através das festanças virtuosas e dos gozos

[ilegítimos!

Louvemo-Lo sempre e sobre tudo! Louvemo-Lo com todos os instrumentos [e todos os ritmos!..."

918 As citações encontram-se em Andrade, Mário de. "Carnaval carioca”, in Clã do Jabuti, in Poesias completas, op. cit., pp. 163-173. 
Uma vez que o ritmo, como vimos, é mana, nada melhor do que ele para louvar o divino, de modo que é o ritmo que opera a passagem do profano no sagrado e do sagrado no profano. Na louvação de "Carnaval carioca", o poeta convoca "todos os ritmos", configurando-se a imagem de uma celebração totalizante, coletiva. Olhando bem, são os ritmos do Brasil que o eu-lírico convida, o que inclui ritmos estrangeiros, como o jazz, "primo" do samba, e os ritmos trazidos pelos imigrantes. Sob a forma do ritmo, o Brasil se reúne em uma espécie de oração festiva, ou seja, num rito mágicoreligioso. A mistura dos ritmos, nesse quadro, é uma imagem do país.

Em carta de 1935, Mário disse que Clã do Jabuti, a que pertence o "Carnaval carioca", como se sabe, é uma "visibilíssima busca de Brasil e de fusão brasileira"919. O carnaval, dessa forma, afigurava-se como tema privilegiado, tendo em vista que nele parecia realizar-se, à primeira vista, a mistura de toda a sociedade ${ }^{920}$. Com efeito, é propriamente sob a forma da mistura que o eu-lírico de "Carnaval carioca" pretende representar o Brasil. De acordo com Maria Isaura Pereira de Queiroz, a valorização do carnaval como tradição brasileira, e como a festa nacional por excelência, iniciou-se justamente na década de 1920, como resultado da concepção nacionalista e modernista acerca da mistura própria do Brasil: “Os complexos culturais reunindo traços originários de três fontes - a aborígine, a européia e a africana - podiam ser considerados como 'autenticamente' brasileiros"; desse modo, "somente o carnaval popular foi considerado como 'autóctone' por seus contemporâneos, graças a sua mistura de elementos africanos e europeus: a parada das escolas de samba reunia, em cada cortejo, carros alegóricos parecidos aos das cidades européias, mas, entre esses carros, as alas cantam e dançam ao ritmo sincopado de árias afro-brasileiras" ${ }^{921}$. Embora não represente um desfile de escola de samba - o desfiles das escolas ganhariam força apenas no final dos anos 1920 -, o poema de Mário registra essa "trágica mixórdia", como diz o eu-lírico, de

\footnotetext{
${ }^{919}$ Idem. Mário de Andrade escreve cartas a Alceu, Meyer e outros, op. cit., p. 165, grifo meu.

920 Em um estudo importante, em que faz a crítica do que se poderia chamar de "ideologia do carnaval brasileiro", Maria Isaura Pereira de Queiroz demonstra que essa mistura na verdade não ocorre, e que as distinções sociais são preservadas na própria estrutura da festa, de modo que esta não constitui, como se diz, um período de exceção que se opõe ao cotidiano. Queiroz, Maria Isaura Pereira de. Carnaval brésilien: le vécu et le mythe, Paris: Gallimard, 1992.
}

${ }^{921}$ Queiroz, Maria Isaura Pereira de. Op. cit., pp. 172-173. 
elementos culturais africanos e europeus - a negra samba na rua, um carro alegórico passa guiado por Baco -, a que se combina a mistura de raças, sob a forma da convivência - "Isoldas de pijamas bem franceses", "cafrarias desabaladas" - e da miscigenação, que Gilberto Freyre exaltaria dez anos depois: "um negro dois brancos três mulatos, despudores...”. A imagem do Brasil no poema forma-se, sobretudo, a partir dessa perspectiva cultural e racial; a óptica social, que revelaria fraturas e daria ênfase à natureza ilusória da festa, fica em segundo plano, embora esteja presente, produzindo algumas dissonâncias na festa, como se verá.

No carnaval representado no poema de Mário, a fusão brasileira é realizada por meio do ritmo. Mário considerava que o ritmo, uma vez que possui e anula o indivíduo como nenhum outro elemento artístico, tem um poder “coletivizador" insuperável. Ele suprime a distância entre os indivíduos, convertendo-os no "indivíduo grande, dum gesto só, a comunidade" ${ }^{922}$. Nesse sentido, comentando a música dos povos primitivos, em que predomina o elemento rítmico, disse Mário: "Pelos seus valores dinamogênicos, o ritmo produzia a absorção do indivíduo pela coletividade, socializando-o. [...] O Ritmo é socializador. Com suas dinamogenias muito fortes ele coletiviza facilmente os seres"923. Todavia, tendo em vista que essa socialização proporcionada pelo ritmo supõe a aniquilação dos indivíduos, ela se consuma sob o signo do sacrifício e por meio da identificação imediata, ou cega, de modo que o sujeito se torna "vazio de toda dialética entre o particular e o geral", como escreveu Adorno sobre a predominância incontrastável do ritmo na obra de Stravinski ${ }^{924}$. Também no carnaval popular do Rio apresentado por Mário predomina o ritmo, em especial por meio do samba: “pacapacapacapão!... pão! pão!...”, batuca o verso percussivo, interrompendo bruscamente um devaneio católico, subjetivo, do eu-lírico, relançando o poema ao registro da multidão dançante. Todavia, em "Carnaval carioca", a anulação do sujeito pelo ritmo, embora desejada, enfrenta ao mesmo tempo a resistência do sujeito lírico, de modo que possui, em alguma medida, um sentido trágico. Não por acaso, Mário

\footnotetext{
${ }^{922}$ Andrade, Mário de. "Terapêutica musical”, in Namoros com a medicina, op. cit., pp. 54-55.

${ }^{923}$ Idem. Pequena história da música, op. cit., pp. 16, 33.

924 Adorno, Theodor W. Philosophie da le nouvelle musique, op. cit., p. 165.
} 
escreveu a Alceu Amoroso Lima em 1927: “Todo o Clã do Jabuti, principalmente no 'Carnaval Carioca' (poema carnavalesco e que por ser carnavalesco justifica as pândegas do palavriado que estão nele) [...] tem sentimento trágico da vida embora não haja desgraça. E se não tem desgraça tem muita preocupação sofrida e bem vivida" ${ }^{925}$.

O poeta de "Carnaval carioca", entretanto, não pretende apenas representar o transe coletivo, mas deseja realizar no poema a fusão do Brasil no ritmo. Assim, o eulírico procura assumir em seu próprio corpo todos os ritmos da festa, de modo que ele mesmo se constitua como dançarino, ou seja, como um dançarino que reúne em si mesmo todos os ritmos do Brasil. Num primeiro momento do poema, o eu-lírico espera que essa incorporação rítmica, que essa possessão, seja consciente, portanto que ela suponha em alguma medida a distância, o que permitiria a realização de uma espécie de síntese da matéria histórica, que seria superada, ou melhor, transcendida, pela elaboração literária - assim como a festa parece instaurar um outro mundo em relação à realidade cotidiana. O carnaval, porém, por meio da força do ritmo, do poder "epidêmico" da dança ${ }^{926}$, anula a subjetividade do poeta, que se torna algo como um médium passivo, cujos versos seriam a transcrição imediata, "gramofônica", do real:

"Sou o compasso que une todos os compassos

E com a magia dos meus versos

Criando ambientes longínquos e piedosos

Transporto em realidades superiores

A mesquinhez da realidade.

Eu bailo em poemas, multicolorido!

Palhaço! Mago! Louco! Juiz! Criancinha!

Sou dançarino brasileiro!

Sou dançarino e danço! E nos meus passos conscientes

Glorifico a verdade das coisas existentes

\footnotetext{
925 Andrade, Mário de. 71 cartas de Mário de Andrade, op. cit., p. 21.

926 Mário de Andrade comenta as "epidemias coreiformes" em "Terapêutica musical”, in Namoros com a medicina, op. cit., pp. 27-28.
} 
Fixando os ecos e as miragens.

Sou um tupi tangendo um alaúde

E a trágica mixórdia dos fenômenos terrestres

Eu celestizo em euritmias soberanas,

Ôh encantamento da Poesia imortal!...

Onde que andou minha missão de poeta, Carnaval?

Puxou-me a ventania

$[\ldots]$

Morreu o poeta e um gramofone escravo

Arranhou discos de sensações..."

Sendo assim, o eu-lírico de "Carnaval carioca" vem a ser por meio de sua própria morte: ele se constitui por meio de sua supressão, que é realizada pelo poder do ritmo. A lógica da formação supressiva, que estudamos ao longo deste trabalho, instalase portanto no próprio ponto de vista do poema - entendido aqui o conceito de ponto de vista, como vimos com Pasta na primeira parte deste trabalho, como o foco epistemológico, por excelência, da obra literária, ou como sua perspectiva de apreensão da matéria histórica ${ }^{927}$. O partido construtivo dionisíaco, em Mário de Andrade, é um ponto de vista sacrificial, ou seja, é uma forma do que Pasta chamou de ponto de vista da morte, aquele que se forma suprimindo-se, e no qual toma forma paradoxal uma matéria histórica feita de reversibilidades e, como tal, infensa à perspectiva e à síntese. Por isso, o ponto de vista da morte é, também, o ponto de vista impossívelel ${ }^{928}$. Vale notar, porém, que, na forma do transe, o regime da formação supressiva não é assumido pelo eu-lírico de forma consciente e distanciada, ou seja, não é dominado pelo poeta; ao contrário, é o poeta quem é dominado, possuído, por ele. Com isso, o próprio ponto de

\footnotetext{
927 Ver, supra, p. 18.

928 Pasta Júnior, José Antonio. "Le point de vue de la mort”, in op. cit., pp. 157-168.
} 
vista dionisíaco não se universaliza como princípio estruturador do poema, de modo que os versos oscilam entre a destruição da linguagem e uma linguagem tradicional, ou melhor, entre uma linguagem desarticulada pela força da possessão dionisíaca, linguagem em que mediação do sujeito tende a desaparecer, e uma linguagem marcada por uma excessiva distância subjetiva, pelo indivíduo que recua com horror diante da festa. Noutros termos, distância e ausência de distância alternam-se, mas não se dialetizam, o que as leva à exasperação recíproca e ao paroxismo.

Por essa razão, os versos de "Carnaval carioca" oscilam, como notou José Miguel Wisnik, entre um discurso poético quase naturalista, em que a distância máxima em relação aos objetos confunde-se com o preconceito - "cafrarias desabaladas", "o animal desembesta", "as ancas [...] em cio" -, e uma dicção "musical”, em que toda distância entre as palavras e as coisas tende a suprimir-se, de modo que a linguagem tende a perder sua função referencial e tornar-se puro significante - "Fanfarras fanfarrans/fenferrens/finfirrins"; "roncos roucos trilos tchique-tchiques"929. Na mesma linha, a distância permite que o poeta identifique, com ironia, a miséria por trás do disfarce da festa, ou a miséria que a festa não pode disfarçar, sem contudo integrar essas visões aos momentos extasiantes, em que a perspectiva crítica desaparece:

"Ele tinha nos beiços sonoros beijando se rindo

Uma ruga esquecida uma ruga longíqua

Como esgar duma angústia indistinta ignorante...

Só eu pude gozá-la.

E talvez a cama de ferro curta por demais..."

“... Eu enxerguei com estes meus olhos que inda a Terra há-de comer

Anteontem as duas mulheres se fantasiando de lágrimas

A mais nova amamentava o esqueletinho.

Quatro barrigudinhos sem infância, 
Os trastes sem aconchego

No lar-de-todos da rua

O Solzão ajudava a apoteose

Com o despejo das cores e calores..."

A postura distanciada deve-se também ao fato de que o poema, de acordo com seus versos finais, é escrito a partir das recordações do eu-lírico, o que relativizaria, em princípio, a presença imediata dos eventos narrados no corpo do texto, e permitiria, ainda segundo os últimos versos do poema, a formação de um ponto de vista individual, por assim dizer apolíneo, em que o eu-lírico estaria em posse de si mesmo, e a partir do qual as sensações da noite se organizariam de forma serena:

“[...] Fadiga de gozar.

Claros em torno da gente.

Bolas de fitas de papel rolando pelo chão.

Manchas no asfalto.

Os corpos adquirem de novo as sombras deles.

Tem lugares no bar.

As árvores pousam de novo no chão graciosas ordenadas,

Os palácios começam de novo subindo no céu...

$[\ldots]$

Aurora... [...]

Então o poeta vai deitar.

Lentamente se acalma no país das lembranças

A invasão furiosa das sensações. 
O poeta sente-se mais seu.

E puro pelo contato de si mesmo

Descansa o rosto sobre a mão que escreverá."

O início do poema, com efeito, tem algo de uma paisagem. Descortina-se a Guanabara incandescente, em que se misturam, no fogo, cheiros, ruídos e cores, ricos e pobres em riso de febre. Todo o poema, desse modo, encontra-se em alguma medida sob o signo do fogo, o elemento sacrificial por excelência, em que Pasta encontrou uma figura da formação supressiva, uma vez que o fogo se constitui consumindo seus próprios materiais, constitui-se como dissolução, portanto em perpétua evanescência ${ }^{930}$, tendo por isso mesmo, como vimos com Valéry, afinidades eletivas com a dança $\mathrm{a}^{931}$. Os versos, porém, embora ameacem ferver no início, resolvem-se num quadro, em que a linguagem convencional emoldura a imagem do incêndio:

"A fornalha estrala em mascarados cheiros silvos

Bulhas de cor bruta aos trambolhões,

Setins sedas cassas fundidas no riso febril...

Brasil!

Rio de Janeiro!

Queimadas de verão!

E ao longe, do tição do Corcovado a fumarada das nuvens pelo céu."

“Carnaval carioca", em suma, é um poema que oscila entre a distância descritiva e o registro "gramofônico" das sensações, entre uma representação não-dionisíaca do dionisismo e uma linguagem dionisíaca que, em momentos isolados, tende a desintegrar-se como linguagem significativa em aliterações e assonâncias. Embora esses dois "modos" do poema sejam muitas vezes sobrepostos, quando, no entanto, as

\footnotetext{
${ }^{930}$ Pasta Júnior, José Antonio. Pompéia: a metafísica ruinosa d’O Ateneu, op. cit., pp. 79-87.

931 Valéry, Paul. “L’Âme et la danse”, in Eupalinos/L'Âme et la danse/Dialogue de l'arbre, op. cit., p. 143.
} 
imagens são acompanhadas da sonoridade marcada de vogais e consoantes, eles raramente se integram, pois o ritmo, que deveria ser, de acordo com a "idéia" do poema, o princípio de organização da composição, não é incorporado de maneira profunda aos versos livres de "Carnaval carioca", o que ocorrerá em outros poemas de Mário, nos quais o poeta assimila as formas populares do verso medido. Mário, como vimos, considerava o verso livre uma "vitória do individualismo", uma forma apropriada para representar a riqueza do subconsciente e dos ritmos pessoais; o verso livre, nesse sentido, não tem forte "poder socializante". A métrica, por sua vez, "é dinamogênica, fácil de se universalizar", pois "a rima e o metro têm razão, têm motivo imemorial coletivo"932. Ora, no horizonte do "Carnaval carioca", e do "desejo" do eu-lírico, encontra-se o fenômeno da coletivização por meio do ritmo; o poema, contudo, é escrito em versos livres muito semelhantes aos de Paulicéia desvairada, onde a passagem sacrificial do individual no coletivo e vice-versa se opera, mas nos termos da concepção desvairista, não por meio do ritmo.

A síntese superior, na dança, de ritmo, versos livres, sujeito, sociedade e matéria histórica é obtida por Mário de Andrade nas "Danças", de 1924. Nesse longo poema dividido em nove seções, a dança não se dá na festa, como no "Carnaval carioca" ou no "Carro da Miséria". A dança das "Danças" é uma dança do sujeito, do poeta que dança nos dias comuns, não nos festivos, o que contribui para a apreensão dos fenômenos e das estruturas da sociedade. Nessa linha, a dança também não é uma dança tradicional específica, como o samba, mas algo como uma "dança das danças", ou seja, a dança giratória, em que o dançarino gira sobre si mesmo, movimento vertiginoso em que a idéia de dança parece encontrar a sua forma perfeita. Na vertigem das "Danças", o eulírico vê a sociedade brasileira, em particular a sociedade paulistana, no apogeu do surto de modernização baseado nas riquezas do comércio cafeeiro. Assim, de modo paradoxal, o instante supremo da vertigem, que é por definição o instante em que a vista escurece e o indivíduo deixa de ver, esse instante constitui uma espécie de ponto de vista no poema de Mário. Conforme o leitor terá reconhecido, essa visão dada na e pela

\footnotetext{
932 Andrade, Mário de. "A Poesia em 1930", in Aspectos da literatura brasileira, op. cit., pp. 38-40. Idem. A lição do amigo, op. cit., pp. 298-299. Idem. A lição do guru, op. cit., p. 107.
} 
vertigem é, ainda, um modo do ponto de vista da morte, visto algumas páginas atrás, na interpretação do "Carnaval carioca". Nas "Danças", porém, ao contrário do que se verifica no "Carnaval carioca", a estrutura do ponto de vista da morte, sob a forma da vertigem, é assumida pela composição. A instância do eu-lírico se constitui quando o sujeito, no clímax do movimento giratório, ou seja, no instante de máxima intensificação de si mesmo - "EU DANÇO!" - passa no seu outro, a sociedade, que aparece como totalidade auto-sustida:

"Dança a poeira no vendaval.

Raios solares balançam na poeira.

Calor saltita pela praça

\author{
pressa \\ apertos \\ automóveis \\ bamboleiros \\ Pinchos ariscos de gritos
}

Bondes sapateando nos trilhos...

$[\ldots]$

Sucedem quadrilhas...

Gatunos!

Assassinos!

Ciganos!

Judeus!

Quebras formidáveis!

Riquezas fetos de cinco meses

Já velhas como Matusalém.

Baixistas calvos, rotundos, glabros,

Trusts de cana, trusts de arroz,

Açambarcadores de feijão-virado... 


\section{A Bolsa revira.}

Reviram-se as bolsas.

As letras entram.

Os outros saem...

Corrida

tombos

vitórias

delírios

banquetes

orquestras...

Os homens dançam...

Danço também." 933

A vertigem do eu-lírico apreende a vertigem da sociedade, que é a vertigem da modernização conservadora, nosso ritmo histórico paradoxal, em que se combinam o movimento e a imobilidade, ou melhor, em que o movimento afervorado é a própria imobilidade. Sendo assim, a dança giratória, em que coexistem o movimento e a paralisação, em que o movimento acelerado é a paralisação mesma, possui uma relação de homologia estrutural com a modernização conservadora, sendo portanto uma imagem eloqüente dela. Não por acaso, como observou José Antonio Pasta, a imagem ou a estrutura do turbilhão, com seu centro parado, encontra-se em um dos romances mais representativos da literatura brasileira, o Grande Sertão: veredas, de Guimarães Rosa, em que a figura do redemoinho é propriamente nuclear ${ }^{934}$.

Como demonstra o crítico, essa conjunção de movimento e parada encontra-se também em alguns dos "heróis" de nossas letras, da Aurélia alencarina de Senhora ao Riobaldo rosiano, passando, entre outros, por Brás Cubas e Macunaíma. Todas essas

\footnotetext{
${ }^{933}$ Andrade, Mário de. "Danças”, in Remate de Males, in Poesias completas, in op. cit., pp. 215-223.

934 Pasta Júnior, José Antonio. “O romance de Rosa - temas do Grande Sertão e do Brasil”, in op. cit., p. 65.
} 
personagens, diz Pasta, "são muito cambiantes e algumas delas o são de modo muito espetacular, até mesmo algo desconcertante. Às vezes essas mudanças chegam a roçar involuntariamente o cômico e, mesmo, a perturbar a verossimilhança literária dos caracteres - sobretudo quando o modelo da obra, aliás muito transparente, é aquele da subjetividade reflexiva ou exigente, própria à literatura européia romântica e pósromântica"935. O "herói de nossa gente", nesse quadro, "é aquele que exibe de modo mais clamoroso esse traço de metamorfose incessante", sendo também, significativamente, o único que encarna diretamente o Brasil -pois é, por antonomásia, segundo o próprio título do livro - 'o herói sem nenhum caráter'. Mas aqueles que o conhecem sabem que ele não tem nenhum caráter pois ele os tem a todos, passando de um a outro com uma desenvoltura em que mal se distingue a inocência da astúcia ou da malignidade" 936 . Ao mesmo tempo, porém, observa Pasta, "se observarmos um pouco mais nossas personagens infinitamente movediças, vê-se que, ao lado desse traço de mutação incessante, elas são sempre marcadas por um outro traço que, junto ao primeiro, parece paradoxal: elas são todas portadoras de uma idéia fixa, cruel e implacável”, como a muiraquitã macunaímica ou o "emplastro Brás Cubas"937. Com efeito, esses heróis, diz o crítico, em sua movência contínua, engendram novas aparições de si mesmos, mas se repõem, inalterados, em todas elas.

Essa conjunção de movimento incessante e fixidez inamovível, de mudança e repetição, que está na base da modernização conservadora, encontra no turbilhão, mostra Pasta, uma de suas imagens mais perfeitas. A dança giratória do eu-lírico das "Danças", portanto, constitui uma forma privilegiada de apreensão das estruturas históricas brasileiras, em especial na sua versão paulista. São Paulo, com efeito, mais do que qualquer outra cidade brasileira, reproduz, desde que entrou com maior peso na economia nacional, justamente com o café, esse movimento de mudança vertiginosa dos circuitos mercantis e de permanência das estruturas sociopolíticas arcaicas, movimento

\footnotetext{
935 Idem. "Volubilidade e idéia fixa", in op. cit., p. 14. Sobre a volubilidade de Brás Cubas e seu fundamento histórico-social, ver Schwarz, Roberto. Um mestre na periferia do capitalismo, op. cit..

936 Pasta Júnior, José Antonio. "Volubilidade e idéia fixa”, in op. cit., p. 15.

937 Idem. Ibidem, pp. 21-22.
} 
que é também o da própria economia cafeeira, que gira em falso sobre si mesma, consumindo-se em sua própria efervescência, em função de suas insolúveis contradições internas. Estas, de acordo com os estudos sobre o assunto, faziam com que os impulsos de autonomia produtiva implicassem, paradoxalmente, o aprofundamento da dependência, de modo que toda valorização do café resultava em sua depreciação, uma vez que levava ao aumento irrestrito da oferta, necessário para pagar os empréstimos estrangeiros, realizados para valorizar o produto ${ }^{938}$. Desse modo, toda expansão do café paulista significava em si mesma a ruína deste, toda produção implicava a própria destruição - não é à toa que o clímax dessa organização econômica oximoresca é a queima em larga escala do próprio café produzido, para que o café pudesse, por meio da sua extinção, valorizar-se novamente, valorização que exigia, contudo, novos e mais vastos incêndios. São Paulo, assim, oscila sem fim, nos anos 1910-30 - e continuará oscilando até hoje, sob outras formas -, entre o moderno e o arcaico, pois o moderno funda-se no arcaico, assim como o arcaico se funda no moderno, ou seja, pois os impulsos modernizantes da capital têm por base a economia agrária nos moldes coloniais, ao passo que a prosperidade da economia atrasada relaciona-se à modernização dos circuitos comerciais e financeiros internacionais.

A oscilação, com efeito, constitui outra forma de movimento parado, como disse Pasta, que identificou na figura do pêndulo outra imagem, como a do turbilhão, recorrente na literatura brasileira, do ritmo paradoxal que combina movência e paralisação ${ }^{939}$. O movimento que não sai do lugar é também o do vaivém, que incorporado pela "Danças" não apenas no plano das imagens da sociedade paulistana, mas no plano do próprio ritmo binário dos versos, que a todo momento se instala no poema:

“Meu cigarro está aceso.

\footnotetext{
938 Furtado, Celso. Formação econômica do Brasil, op. cit., pp. 177-194. Oliveira, Francisco de. "A emergência do modo de produção de mercadorias: uma interpretação teórica da economia da República Velha no Brasil", in op. cit..

939 Pasta Júnior, José Antonio. Pompéia: a metafísica ruinosa d’O Ateneu, op. cit. .
} 
O fumo esguicha,

O fumo sobe,

O fumo sabe ao bem e ao mal...

O bem e o mal, que coisas sérias!

Riqueza é bem.

Tristeza é mal.

Desastres

sangue

tiros

doença

Dança!...

O elevador subiu aos céus, ao nono andar,

O elevador desce ao subsolo,

Termômetro das ambições.

O açúcar sobe.

O café sobe.

Os fazendeiros vêm do lar.

Eu danço!

Tudo é subir.

Tudo é descer.

Tudo é dançar!"

Como terá notado o leitor, tudo é duplo nos versos acima. O fumo duplicado desdobra-se no bem e no mal: "O fumo esguicha,/ O fumo sobe, $\mathrm{O}$ fumo sobe ao bem e ao mal...”. O bem e o mal, por sua vez, duplicam-se, invertidos na posição da frase, no verso seguinte, desdobrando-se em seguida em dois versos: “O fumo sobe ao bem e ao mal.../ O bem e o mal, que coisas sérias!/ Riqueza é bem./ Tristeza é mal”. Na mesma 
linha, o elevador sobe aos céus e baixa ao subsolo, indicando que a oscilação sem fim se dá entre os opostos extremos. O açúcar duplica-se no café; ambos sobem, gerando a riqueza que faz com que o campo venha para a cidade, com que o mesmo passe no outro. Não por acaso, as passagens incessantes e recíprocas do mesmo no outro, que os versos descrevem com simplicidade admirável, ocorrem na atmosfera turva do fumo, que embaça os limites entre as coisas, facilitando as passagens entre elas. Em meio ao fumo, o mesmo passa no outro. Nessa linha, o fumo, ele mesmo dúplice - “o fumo sabe ao bem e ao mal..." -, espécie de pharmakós, realiza a passagem do ser no não-ser, da matéria no éter, da vítima sacrificial no mundo dos deuses. Em meio ao fumo, homens e mulheres aparecem ao eu-lírico das "Danças" como mortos-vivos, enquanto o próprio eu-lírico se desvanece nas reticências, vindo a ser - "eu vivo no ar" - deixando de ser “morre no ar...":

\author{
"Vejo sonâmbulos ao luar \\ Beijando moças estioladas. \\ Tolos! a poeira sobe no ar... \\ O fumo sobe e morre no ar... \\ Eu vivo no ar! \\ Dançarinar!...”
}

A duplicidade, sob as formas do vaivém, da duplicação de versos, dos versos que se desdobram em duas partes simétricas, dos versos organizados aos pares, dos verso em ritmo binário etc. constitui um dos princípios estruturais do poema:

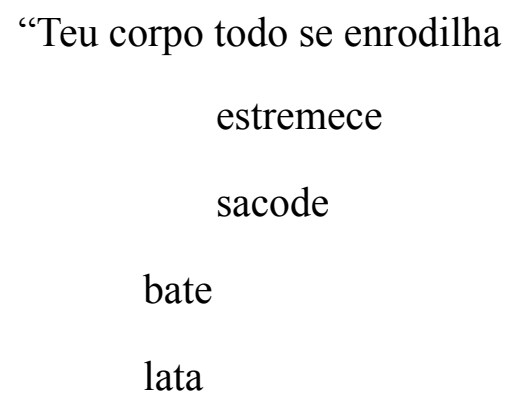


seco

... heque!... heque!...

quebra

queima

reina

dança

sangue

gosma...

Teus lábios dançam:

- Por Piedade!

Não é domingo nem dia-santo!

$[\ldots]$

Aquele quarto me sufoca,

Prefiro ar livre,

Não voltarei.

Ar livre, ar leve que dança, dança!

Dançam as rosas nos rosais!

São flores vermelhas

São botões perfeitos

São rosas abertas, gritos de prazer!

São Paulo é um rosal!

São Paulo é um jardim!

Morena, tem pena,

Tem pena de mim! 
A rosa-riso dança nos teus lábios

vermelhos

mordidos...

Volúpias alegres...

O mundo não vê?

Nós nos separamos.

Nós nos ajuntamos.

$\mathrm{O}$ bonde passou,

$\mathrm{O}$ amigo passou...

O mundo não vê!

A vida é tão curta!

$[\ldots]$

Olha: A Terra é uma bola

A bola gira.

Gira o universo,

Os homens giram também.

Tudo é girar, tudo é rodar.

$[\ldots]$

'Ôh, como passas!'

Bravo! enfim voltas!"

São inimigos,

São morfinômanos, 
Virgens e honestos,

Crápulas vis."

Tudo, no poema, desdobra-se, inverte-se, duplica-se, divide-se ao meio etc., sob a organização do movimento oscilatório, do movimento permanente que todavia não avança, isto é, não produz síntese. As "Danças" de Mário apresentam, com leveza aparente, a imagem terrível de uma história regida pela má-infinidade:

"Dança do berço:

Sim e Não...

Dança do berço:

Não e Sim..."

Nesse contexto em que tudo, na vertigem, é o mesmo e se duplica, também os homens são todos duplos uns dos outros. Todos dançam a mesma dança, a dança giratória que o poema ao mesmo tempo move no ritmo e fixa em uma visão. Por isso, em dado momento, os homens perdem seus nomes no poema de Mário, os nomes que os distinguem uns dos outros, reduzindo-se a pronomes pessoais. O baile dos pronomes é também a imagem da generalização do fenômeno do duplo:

"Filha, tu sabes... que hei-de fazer!

Nós todos somos assim.

Eu sou assim.

Tu és assim.

Dançam os pronomes pessoais.

Nunca em minuetes! Nunca em furlanas! 


\section{NÓS}

\section{ELES}

\section{VÓS}

Não paro.

Não paras.

Sucedem quadrilhas...

$[\ldots]$

Os homens dançam...

Danço também.

Nunca minuetes nem bacanais!

Somos farândulas?

Somos lanceiros?

Somos quadrilhas?

Que somos nós!?

Pronomes pessoais"

Com efeito, a dança, vimos, consiste essencialmente não apenas na mimese do outro, mas na mimese ao extremo, a mimese que inclui o próprio corpo e se consuma na identificação com o outro. Ao mesmo tempo, vimos com Mário que a dança tem o poder de encantar o outro, de fazê-lo dançar também - em suma, de tornar o outro idêntico ao mesmo. Por um lado, o dançarino é o possuído pelo outro; por outro, ele é também aquele que possui o outro. Não é à toa que o próprio poema de Mário tende a encantar seu leitor, como atesta Bandeira, em carta de 1924, referindo-se a Sérgio Buarque de Holanda, que se encontrava por assim dizer "preso" no feitiço das "Danças", repetindo-as a todo momento, o que assinala o êxito da escrita dançada do poema: "Saímos eu, Graça, Villa e Sérgio. Este completamente envouté pelas "Danças". 
Sabe de cor. Recita e repete" 940 . A dança seduz e chama o outro, de forma irresistível, para a repetição, anulando, como vimos, as distâncias entre os homens; nesse sentido, como disse Mário ao narrar a sua experiência de assistir ao maracatu recifense, a dança não pode ser lida, ela anula a instância do leitor, podendo apenas, agora nas boas palavras de Bandeira, ser recitada e repetida, como num ritual. Assim, as "Danças" de Mário, em jogo hipnótico de vaivéns, em seus diversos ritmos binários recorrentes, tende a passar no seu próprio leitor e a fazê-lo dançar, como afirmou Bastide acerca da poesia marioandradina em geral.

Nessa linha, René Girard escreveu que "a dança acelera o processo mimético", de modo que ela propicia a perda geral das diferenças que antecipa o sacrifício ${ }^{941}$. Vimos, ao longo deste trabalho, que a vítima, para que seja cumprida a sua função expiatória, deve ser idêntica e inversa à sociedade, como uma espécie de espelho em que a comunidade ao mesmo tempo reconhece $e$ não reconhece a si mesma, isto é, a vítima deve ser o duplo de todos, o mesmo e o oposto dos homens. Para que isso possa ocorrer, todos, por sua vez, devem ser duplos uns dos outros, pois sem isso, claro, não pode realizar-se a identificação coletiva diante da vítima.

Como a vítima sacrificial, o eu-lírico das "Danças", ao dançar, torna-se ao mesmo tempo idêntico à sociedade que se apresenta no poema e distinto dela. Sua dança é a "dança de ombros”, ou seja, a dança do cínico, como disse Mário ${ }^{942}$, logo a dança de quem está fora ou à margem da sociedade, dança de afirmação do indivíduo, afirmação que inclui o próprio desapego do sujeito por si mesmo. Todavia, sua dança é também a dança giratória, a dança que o faz perder-se a si mesmo e tornar-se todos os outros. Nos versos abaixo, sucedem-se o gesto de anulação do eu e identificação com todos os homens, por um lado, e o gesto de diferenciação e afirmação do sujeito, por outro:

"Eu sou feliz porque a Terra é uma bola.

\footnotetext{
${ }^{940}$ Idem. Correspondência - Mário de Andrade \& Manuel Bandeira, op. cit., p. 148.

941 Girard, René. Le Bouc émissaire, op. cit., pp. 187-219.

942 "Nem é bem ceticismo a filosofia que ressuma das 'Danças'. É cinismo. Sou cínico, não há dúvida". Andrade, Mário de. A lição do amigo, op. cit., p. 13.
} 
A bola gira,

Gira o universo

Giro também.

Sou Gira.

Sou louco.

Sou Oco.

Sou homem!...

Sou tudo o que vocês quiserem,

Mas que sou?

Meu alfaiate tem mais fregueses.

Não canalha sem virtude.

Não há virtuosos sem desonra.

Entro nos teatros lendo jornais.

Converso pouco e escuto muito.

Falo francês...

Leio em vernáculo Tristram Shandy.

Conheço Freud e Dostoievsky.

Compro as revistas do Brasil.

E

Principalmente

Sei enramar meu ditirambo,

Sei guspir um madrigal!

Depois dou de ombros.

Meus ombros dançam...

Sou partidário da desombra universal" 
A leveza da dança dos ombros não deve enganar o leitor quanto ao sofrimento entranhado nos versos do poema. Ao comunicar a composição do poema a Bandeira, Mário escreve, em 1923: “Acabei um poema. 'Danças'. [...] Prego agora a filosofia do dar-de-ombros. Tem esse versinho que resume todo o meu atual cinismo filosófico: 'São inimigos,/ São morfinômanos,/ Virgens e honestos,/ Crápulas vis./ Saúdo a todos./ Ninguém me estima./ Dançam meus ombros/ Eu sou feliz" "943. Um ano depois, também a Bandeira, Mário especifica o que ele chama de "psicologia da dança de ombro": "Uma aceitação de pesares com o sorriso na boca"944. Assim, começamos a perceber que a satisfação declarada desde o verso de abertura das "Danças" - "Quem disse que não vivo satisfeito! Eu danço!" - esconde o desgosto. Com efeito, Mário dirá a Bandeira, dias após ter-lhe exposto a psicologia da dança de ombro: “O Graça [Aranha] está tão obcecado que acha as minhas 'Danças' alegres (é o que me diz por carta recebida hoje). Ora basta saber ler pra perceber a profunda amargura que há naquele cinismo que é apenas exteriormente alegre" 945 . Por fim, em carta a Drummond, ele revela toda a dimensão da dor que se encontra no poema: “As 'Danças' se escreveram por si num momento de cansaço e de fraqueza. Estava exausto com a campanha de difamação que fizeram contra mim. Sofria muito. Minha inteligência começou a escrever e a dançar as 'Danças'. Em meia hora verdadeiramente aconsciente, estavam escritas as 'Danças', que não sei quem escreveu. Depois o trabalho de poli-las que durou meses. Que tem ali muito de mim é certo. Revelam pra quem souber olhar um sofrimento muito doído. Não há alegria nenhuma nelas. Só o Graça com a mania de pregar a alegria, vê alegria ali. Elas são dolorosas, perversas" 946 . A dança de ombro é aquela que se forma no instante em que o sofrimento, atingindo sua intensidade superlativa, não pode senão passar no seu outro, na felicidade desapegada, como dizem os versos finais do poema:

“... ela dançava porque tossia...

\footnotetext{
943 Idem. Correspondência - Mário de Andrade \& Manuel Bandeira, op. cit., p. 104.

944 Idem. Ibidem, p. 149.

945 Idem. Ibidem, p. 154.

946 Idem. A lição do amigo, op. cit., p. 13.
} 
Outros dançam de soluçar...

Eu danço manso a dança de ombro...

Eu danço... Não sei mais chorar!...”

Segundo o próprio Mário, como vimos acima, escreveu a Drummond, ao dizer que "em meia hora verdadeiramente aconsciente, estavam escritas as 'Danças', que não sei quem escreveu", esse instante supremo em que o sofrimento passa na felicidade, e vice versa, é o instante de um transe, quando a totalidade do sofrimento toma posse do indivíduo e se transfigura em felicidade.

O dançarino que "dá de ombros" é a vítima sacrificial, que carrega o mundo sobre as costas. Sendo assim, a dança de ombro é também uma "dança dramática", não no sentido de que ela se dá durante a representação de um drama, mas no de que ela incorpora todo o drama em si mesma; por meio dela, o sujeito incorpora a totalidade das contradições históricas que procura resolver. Ela é a dança da vítima do sacrifício. 
Bibligrafia 
Adorno, Theodor W.; Horkheimer, Max. Dialética do Esclarecimento, Rio de Janeiro: Jorge Zahar, 1984.

. Notes sur la littérature, Paris: Flammarion, 1999.

. Quasi una fantasia, Paris: Gallimard, 1982.

. Philosophie de la nouvelle musique, Paris: Gallimard, 2000.

- Kierkegaard: construction of the Aesthetic, Minneapolis: Minnesota University Press, 1999.

. Mahler, une physionomie musicale, Paris: Les Éditions de Minuit, 1996.

. Beethoven: The Philosophy of Music (fragments and texts edited by Rolf Tiedemann), Stanford: Stanford University Press, 1998.

. Teoria Estética, Lisboa: Edições 70, 2000.

Albert, Jean-Pierre. Le sang et le Ciel, Mayenne: Aubier, 1997.

Alencastro, Luiz Felipe de. "A pré-revolução de 30", in Novos Estudos CEBRAP, n 18, São Paulo: setembro de 1987.

. "La traite négrière et l'unité nationale brésilienne", in Revue Française d'Histoire d'Outre-Mer, LXVI, 1979, n' 244-245.

Alvarenga, Oneyda. Mário de Andrade, um pouco, Rio de Janeiro: José Olympio, 1974.

Andrade. Mário de, Mário de Andrade escreve cartas a Alceu, Meyer e outros (coligidas e anotadas por Lygia Fernandes), Rio de Janeiro: Editora do Autor, 1968. 
. Introdução à Estética musical (estabelecimento do texto, introdução e notas de Flávia Camargo Toni), São Paulo: Hucitec, 1995.

. O turista aprendiz (estabelecimento do texto, introdução e notas de Telê Porto Ancona Lopez), Belo Horizonte: Itatiaia, 2002,

- 71 cartas de Mário de Andrade (coligidas e anotadas por Lygia Fernandes), Rio de Janeiro: São José, s/d.

. A lição do amigo: cartas de Mário de Andrade a Carlos Drummond de Andrade (anotadas pelo destinatário), Rio de Janeiro: José Olympio, 1982.

. Táxi e crônicas do Diário Nacional, Belo Horizonte: Itatiaia, 2005.

. Aspectos da música brasileira, Belo Horizonte/Rio de Janeiro: Villa Rica, 1991.

. Danças dramáticas do Brasil, Belo Horizonte: Itatiaia, 2002.

. Cartas a um jovem escritor (de Mário de Andrade a Fernando Sabino), Rio de Janeiro: Record, 1981.

. Aspectos das artes plásticas no Brasil, Belo Horizonte: Itatiaia, 1984.

. A lição do guru (cartas a Guilherme Figueiredo, 1937-45), Rio de Janeiro: Civilização Brasileira, 1989.

. Dicionário musical brasileiro (coordenação de Oneyda Alvarenga e Flávia Camargo Toni), Belo Horizonte: Itatiaia, 1999.

. Os filhos da Candinha, Belo Horizonte: Itatiaia, 2006. 
. Música de feitiçaria no Brasil, Belo Horizonte/Brasília: Itatiaia/Instituto Nacional do Livro, 1983.

. Música, doce música, Belo Horizonte: Itatiaia, 2006.

. Contos novos, Belo Horizonte: Itatiaia, 1999.

. Cartas de Mário de Andrade a Prudente de Moraes, neto - 1924/36 (organizado por Georgina Koifman), Rio de Janeiro: Nova Fronteira, 1985.

. Poesias completas (ed. crítica de Diléa Zanotto Manfio), Belo Horizonte/ Rio de Janeiro: Villa Rica, 1993.

. O banquete, São Paulo: Duas cidades, 1989.

. Ensaio sobre a música brasileira, Belo Horizonte: Itatiaia, 2006.

. O empalhador de passarinho, Belo Horizonte: Itatiaia, 2002.

. Pequena história da música, Belo Horizonte: Itatiaia, 1987.

. O baile das quatro artes, São Paulo: Martins, 1975.

. Correspondência - Mário de Andrade \& Tarsila do Amaral (organização, introdução e notas de Aracy Amaral), São Paulo: Edusp/IEB, 2001.

. Cartas a Murilo Miranda (1934-1945), Rio de Janeiro: Nova Fronteira, 1981.

. Aspectos da literatura brasileira, Belo Horizonte: Itatiaia, 2002.

. Macunaíma, o herói sem nenhum caráter (edição crítica organizada por Telê Porto Ancona Lopez). ALLC XX/Editora da UFRJ, Coleção Archivos, 1996. 
. Mário de Andrade-Oneyda Alvarenga: cartas, São Paulo: Duas Cidades, 1983.

. As melodias do boi e outras peças (preparação, introdução e notas de Oneyda Alvarenga), São Paulo: Duas Cidades/ Instituto Nacional do Livro, 1987

. Os cocos (preparação, ilustração e notas de Oneyda Alvarenga), Belo Horizonte: Itatiaia, 2002.

. Entrevistas e depoimentos (edição organizada por Telê Porto Ancona Lopez), São Paulo: T. A. Queiroz, 1983.

. Correspondência - Mário de Andrade \& Manuel Bandeira (organização de Marcos Antonio de Moraes), São Paulo: Edusp/IEB, 2000.

. Vida do cantador, Belo Horizonte, Rio de Janeiro: Villa Rica, 1993.

. Namoros com a medicina, Belo Horizonte: Itatiaia,1980.

Andrade, Oswald de. Poesias reunidas, Rio de Janeiro: Civilização Brasileira, 1974.

Arantes, Paulo Eduardo. Sentimento da dialética na experiência intelectual brasileira: dialética e dualidade segundo Antonio Candido e Roberto Schwarz, São Paulo: Paz e Terra, 1992.

; Arantes, Otília Beatriz Fiori. Sentido da formação: três estudos sobre Antonio Candido, Gilda de Mello e Souza e Lúcio Costa, São Paulo, Paz e Terra, 1997.

Aristóteles. L'homme de génie et la mélancolie, Paris: Rivages, 1988.

. "Política", in Os Pensadores - Aristóteles, São Paulo: Nova Cultural, 2000. 
Arrigucci Jr., Davi. Humildade, paixão e morte, São Paulo: Companhia das Letras, 1999.

Assis, Machado de. Obra completa, 3 vls., Rio de Janeiro: Aguilar, 1997.

Attali, Jacques. Bruits, Paris: Fayard/Puf, 2001.

Auerbach, Erich. Mimesis, Paris: Perspectiva, 2001.

Avancini, José Augusto. Expressão plástica e consciência nacional na crítica de Mário de Andrade, Porto Alegre: Editora da UFRS, 1998.

Baas, Bernard. "Le Sacré: la présence et l'excès", in Poizat, Michel (org.). Musique et Sacré, Brou: Ambronay, 2004.

Bachelard, Gaston. La psychanalyse du feu, Paris: Gallimard, 2006,

Bakhtin, Mikhail. Problemas da poética de Dostoiévski, Rio de Janeiro: Forense, 2003.

. A cultura popular na Idade Média e no Renascimento: o contexto de François Rabelais, São Paulo: Hucitec, 2008.

Bandeira, Manuel. Apresentação da poesia brasileira, São Paulo: Cosac \& Naify, 2009. . Estrela da vida inteira, Rio de Janeiro: Nova Fronteira, 1993.

Barthes, Roland. Le bruissement de la langue, Paris: Seuil, 1984.

. Fragmentos de um discurso amoroso, São Paulo: Martins Fontes, 2003.

Bastide, Roger. Éléments de sociologie religieuse, Paris: Stock, 1997. 
. Le candomblé de Bahia (rite Nagô), Paris: Plon, 2000.

. Les problèmes de la vie mystique, Paris: PUF, 1996.

. Les religions africaines au Brésil, Paris : PUF, 1995.

. O sagrado selvagem, São Paulo: Companhia das Letras, 2006.

Bataille, Georges. La part maudite, Paris: Minuit, 2007.

. Théorie de la religion, Paris: Gallimard, 1973.

Batista, Marta Rossetti; Lopez, Telê Porto Ancona; Lima, Yone Soares de (orgs.).

Brasil: $1^{\circ}$ tempo modernista - 1917/29, São Paulo: IEB/USP, 1972.

Beiguelman, Paula. A formação do povo no complexo cafeeiro: aspectos políticos, São Paulo: Pioneira, 1978.

Benjamin, Walter. Obras escolhidas, volume I-Magia e técnica, arte e política, São Paulo: Brasiliense, 2008.

. Obras escolhidas, volume II - Rua de mão única, São Paulo: Brasiliense, 2000.

. Origem do drama barroco alemão, São Paulo: Brasiliense, 1984.

. Charles Baudelaire: un poète lyrique à l'apogée du capitalisme, Paris:

Payot, 1990.

. Écrits français, Paris: Gallimard, 2003.

. Reflections: essays, aphorisms and autobiographical writings, New York:

Schocken, 1989. 
Berardinelli, Alfonso. Da poesia à prosa, São Paulo: CosacNaify, 2007,

Boissière, Anne; Kintzler, Catherine (org.). Approche philosophique du geste dansé, Villeneuve d'Ascq: Setentrion, 2006.

Bolle, Willi. "A cidade sem nenhum caráter: leitura de Paulicéia desvairada de Mário de Andrade", in Revista Espaço \& Debates, n 27, São Paulo: Annablume, 1989.

Borel, Vincent. Un curieux à l'opéra, Arles: Actes Sud, 2006.

Bosi, Alfredo. "Um mito sacrificial: o indianismo de José de Alencar", in Dialética da colonização, São Paulo: Companhia das Letras, 1992.

. Céu, inferno, São Paulo: Editora 34/Duas Cidades, 2003.

Brecht, Bertolt. "Sur l'emploi de la musique pour un théâtre épique", in Écrits sur le théâtre, "La Pléiade", Paris: Gallimard, 2000.

Brito, Mário da Silva. História do Modernismo brasileiro, I-Antecedentes da Semana de Arte Moderna, Rio de Janeiro: Civilização Brasileira, 1978.

Caillois, Roger. L’homme et le sacré, Paris: Gallimard, 2006.

Campos, Haroldo de. Morfologia do Macunaíma, São Paulo : Perspectiva, 2008.

Camus, Albert. Le mythe de Sisyphe: essai sur l'absurde, Paris: Gallimard, 1999.

Candido, Antonio. A educação pela noite e outros ensaios. São Paulo: Ática, 2000.

. O discurso e a cidade, São Paulo/Rio de Janeiro: Duas Cidades/Ouro sobre Azul, 2004.

. Vários escritos, São Paulo: Duas Cidades, 1995. 
. Formação da literatura brasileira, 2 vols., Belo Horizonte: Itatiaia, 1997

. Literatura e sociedade, São Paulo: T. A. Queiroz, 2000.

. Tese e antítese, São Paulo: T. A. Queiroz, 2002.

. (org.). Sérgio Buarque de Holanda e o Brasil, São Paulo: Fundação Perseu

Abramo, 1998.

Carone, Edgard. A República Velha (instituições e classes sociais), São Paulo: Difusão Européia do Livro, 1970.

. Movimento operário no Brasil (1877-1944), São Paulo: Difel, 1984.

Carvalho, José Murilo de. Os bestializados: o Rio de Janeiro e a República que não foi, São Paulo: Companhia das Letras, 2008.

Cassirer, Ernst. Linguagem e mito, São Paulo: Perspectiva, 2003.

Castro, Eduardo Viveiros de. A inconstância da alma selvagem. São Paulo: CosacNaify, 2002.

Castro, Moacir Werneck de. Mário de Andrade: exílio no Rio, Rio de Janeiro: Rocco, 1989.

Chauí, Marilena. Brasil, mito fundador e sociedade autoritária, São Paulo: Perseu Abramo, 2001.

Chertok, Leon. L'hypnose. Paris: Payot, 2002.

Coli, Jorge. Música final: Mário de Andrade e sua coluna jornalística Mundo musical, Campinas: Editora da Unicamp, 1998. 
. "Mário de Andrade - Introdução ao pensamento musical", in Revista do Instituto de Estudos Brasileiros, n 12. São Paulo: USP-IEB, 1972, pp. 111-136.

Combarieu, Jules. La musique et la magie, Genbra: Minkoff, 1978.

Costa, Iná Camargo. "Mário de Andrade e o Primeiro de Maio de 35", in Trans/Form/ Ação: Revista de Filosofia, vol. 18., São Paulo, Unesp, 1995.

Dahlhaus, Carl. The idea of absolute music, Chicago: University of Chicago Press, 1991.

. Esthetics of music, Cambridge: Cambridge University Press, 1995,

Dandrey, Patrick. Anthologie de l'humeur noire: écrits sur la mélancolie d'Hippocrate à l’Encyclopédie. Paris: Le Promeneur, 2005.

Dantas, Vinícius. "Entre 'A negra' e a Mata Virgem", in Novos Estudos CEBRAP, n 45, São Paulo: 1996, pp. 100-116.

Dassin, Joan. Política e poesia em Mário de Andrade, São Paulo: Duas Cidades, 1978.

Dean, Warren. A industrialização de São Paulo (1880-1945), São Paulo: Difel, s/d.

Deleuze, Gilles. Sacher-Masoch: o frio e o cruel, Rio de Janeiro: Zahar, 2009. . Crítica e clínica, São Paulo: Editora 34, 2008.

Detienne, Marcel. Dionysos à ciel ouvert, Paris : Hachette, 1998. . Les dieux d'Orphée, Paris: Gallimard, 2007.

Duarte, Paulo. Mário de Andrade por ele mesmo, São Paulo: Hucitec, 1977. 
Durkheim, Émile. As formas elementares da vida religiosa, São Paulo: Martins Fontes, 2003.

Eagleton, Terry. Ideologia: uma introdução, São Paulo: Boitempo, 1997. . O suicídio, São Paulo: Martins Fontes, 2004.

Eliade, Mircea. O sagrado e o profano, São Paulo: Martins Fontes, 2001. . Initiation, rites, sociétés secrètes, Paris: Gallimard, 1959.

Faoro, Raymundo. Os donos do poder: formação do patronato político brasileiro, São Paulo: Globo, 2008.

Fausto, Boris. A Revolução de 1930: historiografia e história, São Paulo: Brasiliense, 1976.

(org.). História geral da civilização brasileira, tomo III: o Brasil Republicano, $1^{\circ}$ volume - estrutura de poder e economia (1889-1930). Rio de Janeiro: Bertrand Brasil, 1997.

- "Estado, classe trabalhadora e burguesia industrial (1920-1945): uma revisão", in Novos Estudos CEBRAP, n 20, São Paulo: Marco de 1988, pp. 6-37.

Fernandes, Florestan. A revolução burguesa no Brasil. Ensaio de interpretação sociológica, São Paulo: Globo, 2006.

. Folclore e mudança social na cidade de São Paulo, São Paulo: Martins Fontes, 2004.

Frazer, James George. Le Rameau d'Or, Paris: Robert Laffont, 1981. 
Freud, Sigmund. "Luto e melancolia", in Revista Novos Estudos CEBRAP, n 32, São Paulo: março de 1992.

Totem et tabou, in Oeuvres complètes, XI, Paris: PUF, 1998.

. L'inquiétante étrangenté et autres essais, Paris: Gallimard, 2003,

. "Psicologia de grupo e análise do ego", in Obras completas, XVIII, Rio de Janeiro: Imago, 1976.

Freyre, Gilberto. Casa-grande \& senzala, Rio de Janeiro: Record, 1989.

Friedrich, Hugo. Structure de la poésie moderne, Paris: Le Livre de Poche, 2004.

Fubini, Enrico. L'estetica musicale dall'antichità al Settecento, Torino: Einaudi, 2002.

Furtado, Celso. Formação econômica do Brasil, São Paulo: Companhia Editora Nacional, 2003.

Girard, René. Le bouc émissaire, Paris: Grasset \& Fasquelle, 2006.

. A violência e o sagrado, São Paulo: Paz e Terra, 1998.

Goethe, Johann Wolfgang von. Conversations avec Eckermann, Paris: Gallimard, 2001. . Fausto, Belo Horizonte: Villa Rica, 1992.

Hanslick, Eduard. Du beau dans la musique, Villiers-sur-Marne: Phénix, 2004.

Hegel, G. W. F., Leçons sur la philosophie de la religion, Paris: Vrin, 1972. . Fenomenologia do Espírito, Petrópolis: Vozes, 2003. 
. Curso de Estética: o Belo na Arte, São Paulo: Martins Fontes, 1996.

. Curso de Estética: o Sistema das Artes, São Paulo: Martins Fontes, 1996.

Herrenschmidt, Olivier. "A qui profite le crime? Cherchez le sacrifiant”, in L'homme. Revue française d'anthropologie, XVIII (1-2), Paris: EHESS, jan/jun 1978.

. "Sacrifice symbolique ou sacrifice efficace", in Izard, Michel; Smith,

Pierre (orgs.). La fonction symbolique: essais d'anthropologie, Paris: Gallimard, 1979.

Hesíodo. Teogonia: a origem dos deuses, São Paulo: Iluminuras, 2007.

Heusch, Luc de. Le sacrifice dans les religions africaines, Paris: Gallimard, 1986.

. La transe, Bruxelas: Complexe, 2006.

Holanda, Sério Buarque de. Raízes do Brasil, São Paulo: Companhia das Letras, 2002.

Ingarden, Roman. Qu'est-ce qu'une oeuvre musicale?, Paris: Christian Bourgois, 1989.

Ivo, Lêdo. Lição de Mário de Andrade, Rio de Janeiro: Depto. de Imprensa Nacional, 1952.

Jacquemard, Simone; Brosse, Jacques. Orphée, Paris: Bayard, 1998.

Jakobson, Roman. "Linguistique et poétique", in Essais de lingustique générale - 1. Les fondations du langage, Paris: Minuit, 1991.

Jankélévitch, Vladimir. La Musique et l'Ineffable, Paris: Seuil, 2002.

. La musique et les heures, Paris: Seuil, 1988.

. La mort, Paris: Flammarion, 1999. 
. Liszt: rhapsodie et improvisation, Paris: Flammarion, 1998.

Jeanmaire, Henri. Dionysos: histoire du culte de Bacchus, Paris: Payot, 1991.

Jolles, André. Formas simples, São Paulo: Cultrix, 1976.

Kaiser, Wolfgang. Análise e interpretação da obra literária, Coimbra: Armênio Amado, 1970.

Kant, Immanuel. Duas introduções à Crítica do Juízo (organização de Ricardo Ribeiro Terra), São Paulo: Iluminuras, 1995.

Kempis, Thomas de. A imitação de Cristo [séc.XV], São Paulo: Paulinas, 2009.

Kierkegaard, Søren. Either/Or - A fragment of life, Londres: Penguin, 1992.

. Fear and Trembling, Londres: Penguin, 2003.

Klibansky, Raymond; Panofsky, Erwin; Saxl, Fritz. Saturne et la mélancolie (études historiques et philosophiques: nature, religion, médecine et art), Paris: Gallimard, 2004.

Knoll, Victor. Paciente arlequinada: uma leitura da obra poética de Mário de Andrade, São Paulo: Hucitec, 1983,

Konder, Leandro. A derrota da dialética: a recepção das idéias de Marx no Brasil, até o começo dos anos 30, São Paulo: Expressão Popular, 2009.

Kristeva, Julia. La Révolution du langage poétique, Paris: Seuil, 1974.

Lafetá, João Luiz. 1930: a crítica e o Modernismo, São Paulo: Duas Cidades/Editora $34,2000$. 
. Figuração da intimidade: imagens na poesia de Mário de Andrade, São

Paulo: Martins Fontes, 1986.

Lapassade, Georges. Les rites de possession, Paris: Anthropos, 1997.

Legendre, Pierre. La passion d'être un autre, Paris: Seuil, 2000.

Lévi-Strauss, Claude. Antropologia estrutural, Rio de Janeiro: Tempo Brasileiro, 2003.

. O cru e o cozido, São Paulo: CosacNaify, 2004.

. O pensamento selvagem, Campinas: Papirus, 2007.

Regarder écouter lire, Paris: Plon, 1993.

. Tristes tropiques, Paris: Plon, 1966.

Lewis, Ioan M. Extase religioso, São Paulo: Perspectiva, 1977.

Lima, Luiz Costa. Lira e antilira, Rio de Janeiro: Topbooks, 1995.

Lispector, Clarice. A paixão segundo G. H., Rio de Janeiro: Rocco, 1998.

Lopez, Telê Porto Ancona. Macunaíma: a margem e o texto, São Paulo: Hucitec, 1974.

. Mário de Andrade: ramais e caminho, São Paulo: Duas Cidades, 1972.

- "Riqueza de pobre", in Schwarz, Roberto. Os pobres na literatura brasileira, São Paulo: Brasiliense, 1987, pp. 123-128. 

. "Cronologia geral da obra de Mário de Andrade", in Revista do IEB, $\mathrm{n}^{\mathrm{o}} 7$, São Paulo: USP-IEB, 1969, pp. 139-172.

Löwi, Michel; Sayre, Robert. Révolte et mélancolie: le romantisme à contre-courant de la modernité, Paris: Payot, 2005.

Lukács, Georg. Ensaios sobre literatura, Rio de Janeiro: Civilização Brasileira, 1968.

. A teoria do romance, São Paulo: Duas Cidades/ Editora 34, 2000.

Machado, Carlos Eduardo Jordão. Um capitulo da história da modernidade estética: debate sobre o Expressionismo, São Paulo: Editora da UNESP, 1998.

Major Neto, José Emílio. A Lira Paulistana de Mário de Andrade: a insuficiência fatal do Outro, Tese de Doutoramento em Teoria Literária e Literatura Comparada, São Paulo: FFLCH-USP, 2006.

Mallarmé, Stéphane. La musique et les lettres/Crise de vers, Paris: Ivrea, 1999.

Mallet, Marie-Louise. La musique en respect, Paris: Galilée, 2002.

Mann, Thomas. Doutor Fausto, Rio de Janeiro: Nova Fronteira, 2000.

Marx, Karl. Grundrisse, 1857-1858, México: Siglo Veintiuno, 2007. ; Engels, Friedrich. Obras escolhidas, Lisboa: Avante, 1982.

Matos, Olgária. "A melancolia de Ulisses: a Dialética do Iluminismo e o canto das sereias", in Novaes, Adauto (org.). Os sentidos da paixão, São Paulo: Funarte/ Companhia das Letras, 2009.

Mauss, Marcel. Sociologia e antropologia, São Paulo: Cosac Naify, 2003. 

. Ensaios de sociologia, São Paulo: Perspectiva, 2005.

Miceli, Sérgio. Intelectuais à brasileira, São Paulo: Companhia das Letras, 2008.

Moutsopoulos, Evanghélos. La musique dans l'oeuvre de Platon, Paris: PUF, 1989. . La philosophie de la musique dans la dramaturgie antique: formation et structure, Paris: Vrin, 1999.

Nabuco, Joaquim. Minha formação, Belo Horizonte: Itatiaia, 2004.

Nancy, Jean-Luc. Tombe de sommeil, Paris: Galilée, 2007.

Nietzsche, Friedrich. O nascimento da tragédia, São Paulo: Companhia das Letras, 1999.

. A visão dionisíaca do mundo, São Paulo: Martins Fontes, 2005.

Novaes, Adauto (org.). Os sentidos da paixão, São Paulo: Funarte/Companhia das Letras, 2009.

Novais, Fernando. Portugal e Brasil na crise do Antigo Sistema Colonial (1777-1808), São Paulo: Hucitec, 1995.

. Aproximações, São Paulo: Cosac Naify, 2005.

Oehler, Dolf. $O$ Velho Mundo desce aos infernos: auto-análise da modernidade após o trauma de junho de 1848 em Paris, São Paulo: Companhia das Letras, 1999.

Oliveira, Francisco de. Crítica à razão dualista/O ornitorrinco, São Paulo: Boitempo, 2003. 
. “A emergência do modo de produção de mercadorias: uma interpretação teórica da economia da República Velha no Brasil", in Fausto, Boris (org.). História geral da civilização brasileira, tomo III: o Brasil Republicano, $1^{\circ}$ volume - estrutura de poder e economia (1889-1930). Rio de Janeiro: Bertrand Brasil, 1997.

Otto, Rudolf. Le sacré, Paris: Payot, 2004.

Pasta Júnior, José Antonio. Pompéia: a metafísica ruinosa d’O Ateneu, Tese de Doutoramento em Literatura Brasileira, São Paulo: FFLCH-USP, São Paulo, 1991.

- Trabalho de Brecht (breve introdução ao estudo de uma classicidade contemporânea), São Paulo: Duas Cidades/ Editora 34, 2010.

. "Tristes estrelas da Ursa - Macunaíma", in Cadernos Porto \& Vírgula, no 4, Porto Alegre: Secretaria Municipal de Cultura, 1993.

. "O romance do Rosa - temas do Grande Sertão e do Brasil", in Novos Estudos CEBRAP, nº55, São Paulo: novembro de 1999.

- "Volubilidade e idéia fixa (o outro no romance brasileiro)", in Sinal de menos, nº 4 , São Paulo, 2010.

. "Prodígios de ambivalência", in Novos Estudos CEBRAP, no 64, São Paulo: novembro de 2002.

. "Le point de vue de la mort", in Voies du paysage, Cahiers du crepal, n ๑14, Paris: Presses Soubonne Nouvelle, 2007.

Pinto, Edith Pimentel. A Gramatiquinha de Mário de Andrade: texto e contexto, São Paulo: Duas Cidades, 1990.

Prado Júnior, Caio. História econômica do Brasil, São Paulo: Brasiliense, 2002. 
Proença, M. Cavalcanti. Roteiro de Macunaíma, Rio de Janeiro: Civilização Brasileira, 1978.

Queiroz, Maria Isaura Pereira de. O messianismo no Brasil e no mundo, São Paulo: Dominus/USP, 1965.

. Carnaval brésilien: le vécu et le mythe, Paris: Gallimard, 1992.

Rabelo, Ivone Daré. A caminho do encontro: uma leitura de Contos Novos, São Paulo: Ateliê, 1999.

Raymond, Marcel. De Baudelaire ao surrealismo, São Paulo: Edusp, 1997.

Reik, Theodor. Le masochisme, Paris: Payot, 2000.

Revista do Arquivo Municipal, CVI. São Paulo: Prefeitura de São Paulo/Departamento de Cultura, 1946.

Revista do Instituto de Estudos Brasileiros, $\mathrm{n}^{\mathrm{o}} 36$ (número dedicado a Mário de Andrade). São Paulo: USP-IEB, 1994.

Rougemont, Denis de. L'amour et l'Occident, Paris: Plon, 2006.

Rosenfeld, Anatol. Texto/Contexto I, São Paulo: Perspectiva, 1996.

Rouget, Gilbert. La musique et la transe, Paris: Gallimard, 2004.

Rousseau, Jean-Jacques. Essai sur l'origine des langues, Paris: Gallimard, 1990. . Dictionnaire de musique, Arles: Actes Sud, 2007.

Samosate, Lucien de. Éloge de la danse, Paris: Arléa, 2007. 
Sapir, Edward. Le langage: introduction à l'étude de la parole, Paris: Payot, 2001.

Sartre, Jean-Paul. O que é a literatura?, São Paulo: Ática, 1948.

Schopenhauer, Arthur. Metafísica do Belo, São Paulo: Unesp, 2001.

. O mundo como vontade e representação, Rio de Janeiro: Contraponto, 2001.

Schwarz. Roberto, Ao vencedor as batatas, São Paulo: Duas Cidades/Editora 34, 2000.

. Um mestre na periferia do capitalismo, São Paulo: Editora 34/Duas

Cidades, 2000.

. A sereia e o desconfiado, São Paulo: Paz e Terra, 1981.

. Que horas são?, São Paulo: Companhia das Letras, 1997.

. Seqüências brasileiras, São Paulo: Companhia das Letras, 1999.

. Duas meninas, São Paulo: Companhia das Letras, 1997.

Skidmore, Thomas. Brasil: de Getúlio a Castelo, São Paulo: Paz e Terra, 1992.

Souza, Eneida Maria de. A pedra mágica do discurso, Belo Horizonte: Editora UFMG, 1999.

Souza, Gilda de Mello e. Exercícios de leitura, São Paulo: Duas Cidades, 1980.

. A idéia e o figurado, São Paulo: Editora 34/Duas Cidades, 2005.

. O tupi e o alaúde, São Paulo: Editora 34/Duas Cidades, 2003 
Spitzer, Leo. Três poemas sobre o êxtase, São Paulo: CosacNaify, 2003.

Staiger, Emil. Conceitos fundamentais da Poética, Rio de Janeiro: Tempo Brasileiro, 1997.

Szondi, Peter. Ensaio sobre o Trágico, Rio de Janeiro: Jorge Zahar, 2004.

Trumbull, H. Clay. The threshold covenant or the beginning of religious rites, Whitefish: Kessinger, 2008.

. Blood covenant, Whitefish: Kessinger, 2009.

Vadé, Yves. L'enchantement littéraire: écriture et magie de Chateaubriand à Rimbaud, Paris : Gallimard, 1990.

Valéry, Paul. Eupalinos/L'Ame et la danse/Dialogue de l'arbre, Paris : Gallimard, 2008. . Euvres I, Paris: Gallimard, Bibliothèque de la Pléiade, 1957.

. Degas Danse Dessin, Paris : Gallimard, 1965.

Van der Leeuw, G. La religion dans son essence et ses manifestations. Phénoménologie de la religion, §48, “Comportement et célébration”, Paris: Payot, 1970.

Van Gennep, Arnold. Les rites de passage, especialmente os capítulos I e II. Paris: Picard, 2004.

Vernant, Jean-Pierre. Mythe et religion en Grèce ancienne, Paris: Seuil, 1990. . Mito e pensamento entre os gregos: estudos de psicologia histórica, São Paulo: Difusão Européia do Livro/ Edusp, 1973. 
La mort dans les yeux: figure de l'Autre en Grèce ancienne, Paris:

Hachette, 1998.

; Vidal-Naquet, Pierre. Mythe et tragédie en Grèce ancienne, Paris: La Découverte, 2001.

Weber, Max. Sociologie de la religion, Paris: Flammarion, 2006.

Wisnik, José Miguel. Dança dramática (poesia/ música brasileira), Tese de Doutoramento em Teoria Literária e Literatura Comparada, Sao Paulo: FFLCH-USP, 1979.

Žižek, Slavoj. La Seconde mort de l'Opéra, Paris: Circé, 2006. 